\title{
AN ENVIRONMENTAL OVERVIEW OF GEOTHERMAL DEVELOPMENT: THE MONO-LONG VALLEY KGRA
}

\section{January 1979}

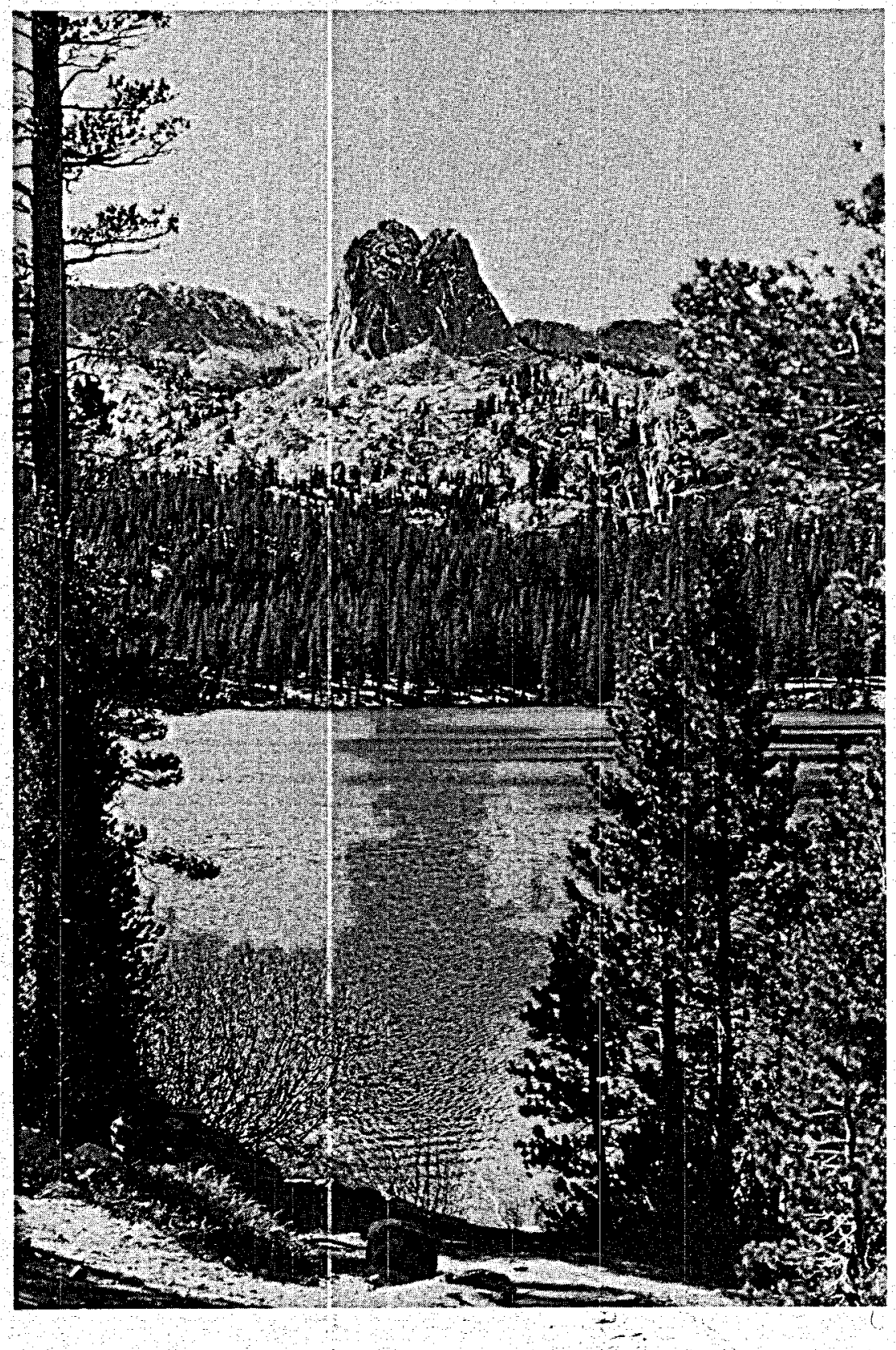

LABORATORY OF NUCLEAR MEDICINE. AND RADIATION BIOLOGY

UNIVERSITY OF CALIFORNIA, LOS ANGELES

P. 0.1596609 DISTRIBUTION OF THIS DOCUMENT IS UNLIMITEDLP 


\section{DISCLAIMER}

This report was prepared as an account of work sponsored by an agency of the United States Government. Neither the United States Government nor any agency Thereof, nor any of their employees, makes any warranty, express or implied, or assumes any legal liability or responsibility for the accuracy, completeness, or usefulness of any information, apparatus, product, or process disclosed, or represents that its use would not infringe privately owned rights. Reference herein to any specific commercial product, process, or service by trade name, trademark, manufacturer, or otherwise does not necessarily constitute or imply its endorsement, recommendation, or favoring by the United States Government or any agency thereof. The views and opinions of authors expressed herein do not necessarily state or reflect those of the United States Government or any agency thereof. 


\section{DISCLAIMER}

Portions of this document may be illegible in electronic image products. Images are produced from the best available original document. 


\section{NOTICE}

This report was prepared as an account of work sponsored by the United States Government. Neither the United States nor the United States Department of Energy, nor any of their employees, nor any of their contractors, subcontractors, or their employees, makes any warranty, express or implied, or assumes any legal liability or responsibility for the accuracy, completeness or usefulness of any information, apparatus, product or process disclosed, or represents that its use would not infringe privately-owned rights.

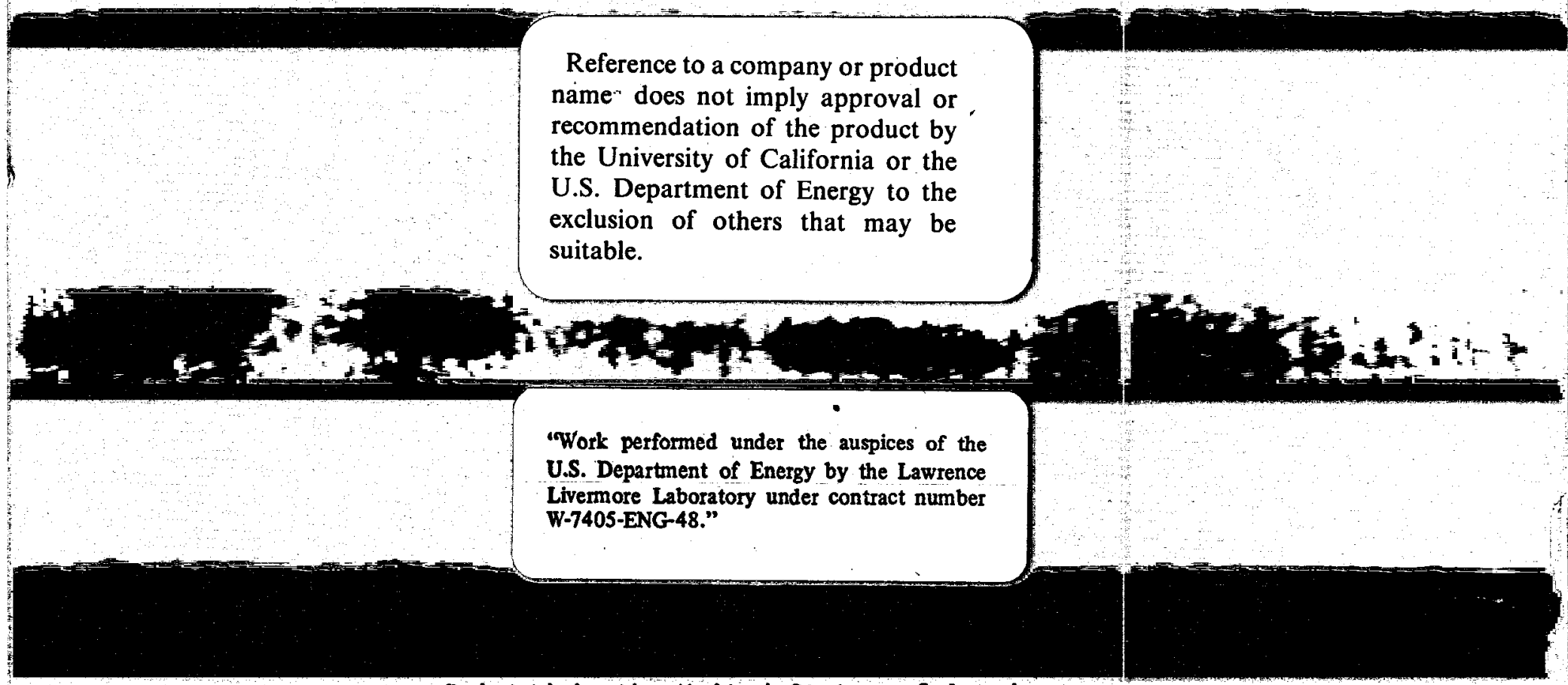

Printed in the United States of America

Available from:

National Technical Information Service U.S. Department of Commerce

5285 Port Royal Road

Springfield, VA 22161

Price: Printed Copy $\$ 11.00$ Microfiche $\$ 3.00$ 


\author{
LABORATORY OF NUCLEAR MEDICINE \\ AND RADIATION BIOLOGY \\ UNIVERISTY OF CALI FORNIA, LOS ANGELES
}

\title{
AN ENVIRONMENTAL OVERVIEW \\ OF GEOTHERMAL DEVELOPMENT:
}

THE MONO-LONG VALLEY KGRA

Edited by Carl L. Strojan

and Evan M. Romney

January 1979

This noport NoTice

sponsored by the United States an sccount of work

United States nor the Unites Govemment. Nejther the

Energy, nor any of their on stes Department of

contractors, aubco of their employeet, not any of their

any warronty, subcontrictors, or their employees, makes

liability or

or useful of and the aceuncy, completenexs

proceses diccos any information, apparatus, product or

process discloved, or nepresents that its use would not
infringe privately owned nights.

\section{Prepared for \\ Lawrence Livermore Laboratory Environmental Sciences Division \\ University of California, Livermore, CA 94550}




\section{PREFACE}

The following environmental report on Mono-Long Valley Known Geothermal Resource Area (KGRA) is part of the U.S. Department of Energy's Geothermal Overview Project which is administered by the University of California, Lawrence Livermore Laboratory. The purpose of the Geothermal Overview Project is to provide the U.S. Department of Energy with information on existing environmental data and major environmental issues, and to make recommendations for resolving these issues.

Environmental overview reports have been or are being prepared for KGRA's which have the greatest potential for commercial geothermal development. Information contained in the reports is intended for use in planning and decision making. Although this report has been prepared for the Assistant Secretary for Environment, U.S. Department of Energy, it is our hope that the contents will also be of use to others in the public and private sectors who are concerned with developing geothermal resources in an environmentally sound manner.

One of the keys to the Geothermal Overview Project is the early involvement of all interested parties, including representatives of local, state and federal government, industry, research organizations, consultants, universities, land owners, public interest groups, and local citizens. We sincerely thank all of the individuals and agencies that have helped us with the many phases of our overview study. Without their cooperation, this report would not have been possible. We especially thank Paul Phelps and the Geothermal Overview Project Staff of Lawrence Livermore Laboratory, our advisory committee members, the workshop speakers, discussion leaders and participants, the staff of Warming Hut 2, and the reviewers who critically read draft versions of our final report.

Finally, we gratefully acknowledge the invaluable contributions of Hector Pimentel, who printed the photographs, and Carol Cooper, Debbie Garrison, Linda Stocks, and Robin Townsend, who typed the final report. 
TABLE OF CONTENTS

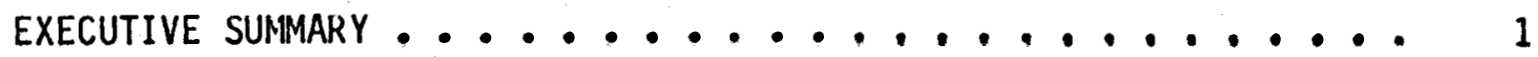

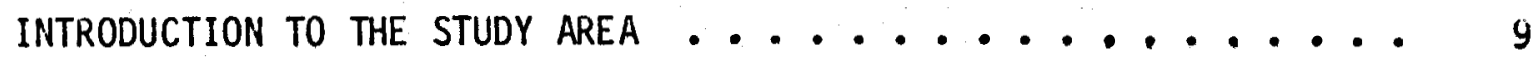
GEOTHERMAL ENERGY DEVELOPMENT IN MONO-LONG VALLEY KGRA ..... 15

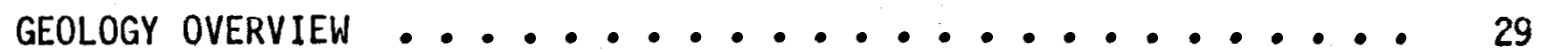

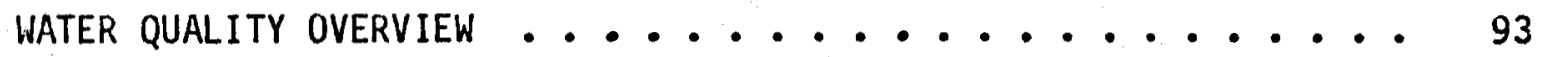

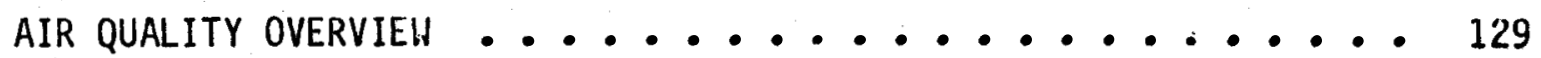
ECOSYSTEMS OVERVIEW ...................... 159

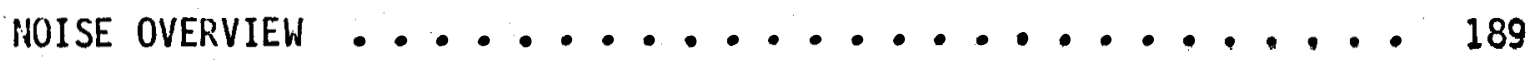
SOCIOECONOMICS OVERVIEW .................. 201 ARCHAEOLOGY AND CULTURAL RESOURCES OVERVIEW ......... 255 APPENDICES

1. LANDS INCLUDED IN MONO-LONG VALLEY KGRA ...... 269

II. AdVISORY COMMITTEE MEMBERS ............. 270 III. WORKSHOP AGENDA ................. 271

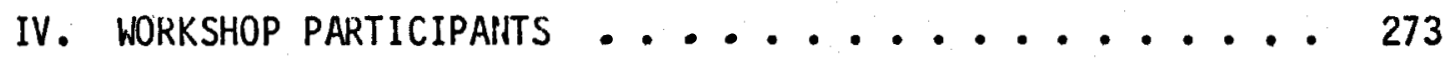




\title{
EXECUTIVE SUMMARY
}

\author{
Carl L. Strojan \\ Laboratory of Nuclear Medicine and Radiation Biology \\ University of California, Los Angeles
}




\section{INTRODUCTION}

The purpose of this environmental overview report is to provide the Assistant Secretary for Environment, U. S. Department of Energy, with site-specific and regional data on environmental aspects of geothermal energy development in Mono-Long Valley KGRA. The information and recommendations included in it are intended for planning relevant research and for making policy decisions.

We have attempted to identify and assess major issues and concerns relating to geothermal development in seven broad areas: (i) air quality, (ii) archaeology and cultural resources, (iii) geology, (iv) natural ecosystems, (v) noise, (vi) socioeconomics, and (vii) water quality. We have also tried to identify and evaluate existing data for each of these areas to determine if the data can be used to help resolve major issues. Finally, we have recommended specific areas where additional data are needed to ensure that geothermal development is environmentally acceptable.

One of our initial steps was the formation of a committee (Appendix II) to assist and advise us during the course of our study. The people on this comittee share a common interest in the Mono-Long Valley region, but otherwise have a range of interests and affiliations. We also contacted numerous other people to help us in identifying major issues, data sources, and research needs.

A very important part of our overview study was a workshop held on August 10-11, 1978 in Mammoth Lakes (Appendix III). Its purpose was to bring together knowledgeable and interested individuals to discuss environmental issues and requirements relative to geothermal development in Mono-Long Valley. About one hundred people attended (Appendix IV), including representatives of local, state and federal government, industry, research organizations, consultants, universities, land owners, public interest groups, and local citizens. Their ideas and recommendations form an integral part of our report.

Based on our review of existing data and the help provided by workshop participants and other contacts, we have developed the following issues and recommendations pertaining to geothermal energy development in Mono-Long Valley KGRA. They are based on the possibility that geothermal development could occur for either space heating or electricity generation. Development for electricity generation has more significant environmental issues and recomendations associated with it than does development for space heating. Priorities were assigned subjectively on the basis of existing data, legal and regulatory considerations, and whether an issue might be a potential obstacle to geothermal development. The large number of high priority issues reflects the environmental sensitivity of the region.

\section{GEOTHERMAL ISSUES. IN MONO-LONG VALLEY KGRA}

Resource size and economics of development (high priority issue) What are the size and heat content of the geothermal reservoir? Can the resource be developed economically, or will direct and indirect government subsidies and environmental tradeoffs be required to convert an intrinsically uneconomical 
venture into one which is merely profitable? While these are not environmental issues, they have a direct bearing on all other issues which are. Because the KGRA is large ( 460,000 acres), environmental concerns can be addressed more specifically only when the size of the resource and the nature and location of any development are better known. On-site drilling has not uncovered the large geothermal reservoir postulated in early estimates for the KGRA. Recent estimates by the U. S. Geological Survey for Long Valley indicate a mean reservoir temperature of about $230^{\circ} \mathrm{C}$ and an electrical energy potential of about $2100 \mathrm{MWe}$ for 30 years. Development has been proposed for electricity generation and space heating. About 26,000 acres are being considered for geothermal leasing by the U. S. Forest Service in Long Valley.

Land use conflicts (high priority issue)

Although Mono-Long Valley is in one of the least populated regions of California, it happens to be one of the most scenic and popular recreation areas in the state. What level of geothermal development is compatible with current land uses for recreation, watershed, grazing, and timber production? What will be the effect of potentially large-scale geothermal development on aesthetics and the "quality of life" in this scenic region? Numerous unknowns make this issue difficult to resolve with existing data. More importantly perhaps, this issue involves questions of human values and priorities, making it less amenable than other issues to resolution through data acquisition and research.

Air quality protection (high priority issue)

There are very few air quality or meteorological data for the KGRA. Existing air quality is generally excellent, however, because of the low population density and lack of industrial development. Blowing dust is an intermittent problem which could be aggravated by large-scale construction. Another important concern for geothermal development is the tendency for strong atmospheric inversions to form in both Mono Basin and Long Valley, areas where any development would most likely occur. Will concentrations of water vapor, hydrogen sulfide, and other potential atmospheric emissions from electricity generation increase under these conditions to the point where they constitute a serious air pollution or visibility problem? If evaporative cooling towers are utflized, will water vapor losses from them cause increased cloudiness, fog, or highway icing in winter? Will this affect operations of the MammothJune Lakes Airport in Long Valley? Additional baseline data and knowledge of development plans are necessary to resolve these issues.

Water quality protection (high priority issue)

Can geothermal waste waters, relatively high in arsenic and boron concentrations, be disposed of without decreasing the excellent quality of surface waters, particularly those of Crowley Lake? Can accidental brine spills be prevented? Nearly all surface waters from the KGRA flow into Crowley Lake, either naturally or as the result of man-made diversions. Waters flowing from Crowley Lake provide about $40 \%$ of the water supply for the City of Los Angeles. Failure to adequately control the discharge of geothermal waters contributed to the closing of several comercial geothermal wells in Long Valley during the 1960 's.

Water supply (high priority issue)

Will an external source of cooling water be required if geothermal-resources are used to generate electricity? If so, how much and from where? Will 
removal of geothermal waters alter surface or ground water hydrology? Water rights are a sensitive issue throughout the arid west, and particularly in the region extending from the Owens Valley to Mono Basin where surface and ground waters are exported some 300 miles to supply the City of Los Angeles.

Natural ecosystems (high priority issue)

Can biological resources, including sensitive plant and animal species and their habitats, be adequately protected? Will geothermal development alter the unique ecological communities which have developed around hot springs and elsewhere in the KGRA? These are more than academic issues, for natural ecosystems form the base of the region's year-round, recreation-oriented economy. Skiers, anglers, hunters, hikers and campers are all attracted by the scenic beauty and diversity of natural ecosystems in the eastern Sierra. Hot Creek is one of the most productive trout streams in the United States. Long Valley contains one of the state's larger populations of sage grouse. Mono Lake is probably one of the most biologically productive lakes in the world--even though its waters are too saline and alkaline for fish. Its populations of brine shrimp and brine flies are the source of food for millions of migratory and nesting birds. At least two rare or endangered plant species and five rare or endangered animal species are found in the KGRA-although some of these occur in areas unlikely to be affected by geothermal development.

Protection of hot springs (high priority issue)

Will geothermal development disrupt the temperature or flow of surface hot springs? In Long Valley such springs are important to the operations of Hot Creek Fish Hatchery, a major trout raising facility operated by the California Department of Fish and Game. These hot springs are also of ecological interest, and several of them are very popular bathing areas. Geothermal drilling in the 1960's has been cited as a reason that hot springs dried up in the Casa Diablo area.

Socioeconomic effects (high priority issue)

Will geothermal development stimulate additional growth and change the economic base of the region? If so, will this complement or displace the existing recreation-oriented economy? About $85 \%$ of the region's economy is now based on recreation and tourism. What will be the fiscal impact of large scale geothermal development in this rural environment ? There are no incorporated towns in the KGRA or elsewhere in Mono County. Are local government and regulatory agencies equipped to deal with large-scale development? How long will the geothermal field remain productive? What happens then?

Archaeological and cultural concerns (high priority issue)

Can archaeological resources and the interests of living Native Americans be protected? Mono-Long Valley is a major archaeological area in California, and numerous sites are located throughout the KGRA. Studies have indicated at least 6,000 years of human occupation in the region. Parts of the KGRA continue to be utilized by Native Americans for food gathering purposes.

Seismicity (medium priority issue)

Will withdrawal or reinjection of geothermal fluids increase earthquake activity in the region? Mono-Long Valley is located in a region of active faulting. One of the strongest earthquakes known to have occurred in California had its epicenter about 80 miles southeast of the KGRA in 1872. More 
recently, an earthquake of magnitude 5.7 occurred just outside the southern boundary of the KGRA in October 1978. Increased seismicity could change the flow of both surface hot springs and the larger underground reservoir, thereby possibly affecting geothermal production.

Cooling tower drift (medium priority issue)

If evaporative cooling towers are used in the generation of electricity, will the deposition of boron, heavy metals, and other elements in water droplets eventually damage native vegetation? Boron from cooling tower drift at The Geysers in northern Callfornia has apparently caused localized damage to native vegetation.

Noise (low priority issue)

Will noise from construction or operation of geothermal facilities become a nuisance, harm the existing tourist trade, or be detrimental to wildiffe. Areas considered most likely for development are several miles from any population center. If adequate mitigation measures are used, noise should not be a major issue for humans or wildl ife.

\section{Ground surface effects (low priority issue)}

Will geothermal development result in increased soil erosion, landslides, subsidence, or soil liquefaction? These are not considered to be major issues for Mono-Long Valley, because of the geologic substrate and surface relief of areas most likely to be developed. Localized soil erosion could be caused by well blowouts or by increased runoff from developed sites. Increased soil erosion resulting in siltation of trout streams would be an issue.

Health effects (low priority issue)

Are there important human health issues related to geothermal development in Mono-Long Valley? Geothermal waters from hot springs and shallow geothermal wells in the area have relatively high concentrations of arsenic and boron. If development occurs for space heating, a closed system would probably be utilized with no discharges to the atmosphere or surface waters. Adequate mitigation measures should protect domestic water supplies from contamination by accidental spills. If development occurs for electricity generation, some atmospheric emission of hydrogen sulfide, boron, and other elements may occur from cooling towers. These should not cause a health problem because of the absence of a population center near areas of proposed development.

Demographic changes (10w priority issue)

Will geothermal development cause population changes in this isolated rural area? Large seasonal changes in population numbers and diversity normally occur in the KGRA because of the influx of tourists. The relatively few people who would be associated with construction or operation of geothermal facilities would therefore have a negligible effect on local demography.

\section{RECOMMENDATIONS}

Recommendations for resolving major issues are summarized below. For more detailed discussions, consult the individual chapters.

Air quality

Baseline data on existing air quality and meteorology are seriously needed, particularly if geothermal development will involve atmospheric emissions. 
Needed information includes baseline chemical data on geothermal gases in Mono-Long Valley, surface meteorological data, and upper level meteorological data. Knowledge of potential atmospheric emissions and natural patterns of dispersal is needed to ensure that existing excellent air quality and visibility are not degraded.

\section{Archaeology}

A specific cultural resource overview should be implemented for the KGRA. Specific cultural resources and/or sites of archaeological significance should be identified in potential lease areas to avoid potential siting conflicts. Potential research areas in the KGRA need to be identified. Full compliance is needed with legal provisions to protect, identify, preserve or mitigate any negative effects from geothermal development on cultural resources.

\section{Geology}

Although there is an excellent existing data base for Long Valley, deep test drilling is needed to accurately determine the size and heat content of the geothermal reservoir. A supplemental geologic survey should be conducted to establish baseline data for use in detecting subsidence or horizontal ground displacement due to geothermal development. Basic data on the hydrologic system and subsurface geology of the Mono Basin, including detailed geophysical studies, need to be collected in order to begin evaluating the geothermal potential of the northern portion of the KGRA. Additional baseline data on microseismicity would be useful, particularly in Long Valley, for comparison with post-development microseismicity. Acquisition of these data, however, would be relatively expensive.

\section{Natural ecosystems}

Data are needed to determine the impact of geothermal fluid withdrawal on the integrity of hot springs, particularly in the Hot Creek area. A thorough and early inventory of rare and endangered plant and animal species should be made to eliminate siting conflicts and potential legal challenges. Baseline conditions should be established to monitor the effects of development on hot spring habitats, and the effects of potential trace element emissions on soils and plant chemistry. Baseline data would be useful on the environmental pathways of potentially toxic elements naturally released by geothermal waters in relatively high concentrations (e.g. arsenic and boron). Strong mitigation measures are needed to prevent the disturbance or destruction of unique and critical habitats for vegetation and wildlife.

Noise

Although adequate information is available to assess the potential for noise impacts from geothermal development in Mono-Long Valley, additional data would be very useful in future impact analyses. Such data should include source term measurements, ambient noise measurements, identification of noise receptor sites, and consideration of noise criteria and standards.

\section{Socioeconomics}

Deep drilling and testing of the geothermal reservoir are needed to accurately determine the economic potential for development. Alternative development scenarios and critical feasibility analyses should be considered, and include the impact of development on recreation and tourism, the fiscal impact on governmental costs and revenues, cooling water requirements and availablity, 
and institutional constraints involving local government and regulatory agencies. Public participation should continue to be encouraged.

Water quality

Sufficient data on the flow and chemistry of surface waters, hot springs, and shallow geothermal well fluids already exist, but data are needed on the chemistry of geothermal fluids from the deeper reservoir likely to be tapped during development. Hydrological data are also needed to determine any connections between the geothermal reservoir and surface hot springs-particularly those which are utilized by Hot Creek Fish Hatchery. Strong mitigation measures are needed to prevent the possible contamination of domestic water supplies by accidental release of geothermal fluids. 


\title{
Chapter 1
}

\section{INTRODUCTION TO THE STUDY AREA}

\author{
Carl L. Strojan \\ Laboratory of Nuclear Medicine and Radiation Biology \\ University of California, Los Angeles
}


The Mono-Long Valley Known Geothermal Resources Area (KGRA) was formed under provisions of the Geothermal Steam Act of 1970. The KGRA is in eastern California about 190 miles east of San Francisco and about 260 miles north of Los Angeles (Fig. 1, Chapter 3). Legal boundaries of the KGRA are given in Appendix I.

Mono-Long Valley is the largest KGRA in the United States, consisting of about 460,256 acres. All of the KGRA is in Mono County, with the exception of about 6600 acres of mountainous terrain in the southwestern corner which extend into Madera County. About 95\% of the land in the KGRA is owned by agencies of local, state or federal governments.

The KGRA is in an area of complex and diverse geological activity. Excellent examples of numerous geological processes can be found, including vulcanism, uplifting, glaciation, and faulting. As a result, many geological investigations have been conducted in the Mono-Long Valley area. Particularly noteworthy has been an extensive research program conducted by the U.S. Geological Survey in Long Valley. Long Valley in fact was chosen as the type area for geothermal hot-water systems.

In addition to forming geological conditions necessary for development of a potential geothermal energy resource, geological forces have helped to create a diverse, and often spectacular, regional topography. Elevation in the KGRA ranges from about $6400 \mathrm{ft}$ above sea level near Mono Lake to slightly over $11,000 \mathrm{ft}$ on Mammoth Mountain. The Sierra Nevada dominate the western boundary of the KGRA and greatly influence local meteorology. Annual precipitation ranges from about 7 inches in eastern Mono Basin to about 56.6 inches at Mammoth Mountain Pass. Most of this precipitation falls as snow during winter.

The relief and climatic gradients result in a diversity of natural ecosystems. Montane habitats are found on the eastern face of the Sierra Nevada. Lower elevations of the KGRA consist of high desert, while higher portions are largely forested.

Numerous streams and lakes occur in the KGRA, including Mono Lake, a large $(2,480,000$ acre $\mathrm{ft})$ inland sea, and Crowley Lake $(183,465$ acre $\mathrm{ft})$. Water quality is generally excellent, and watersheds within the KGRA are the major source of water entering the aqueduct system of the City of Los Angeles.

Prior to the coming of Europeans, the KGRA and surrounding region were important to Northern Paiutes and their predecessors as hunting, gathering, and trading grounds. Numerous artifacts and archeological sites are scattered throughout the KGRA, indicating at least 6,000 years of occupation. Descendants of these ancient people still live in the surrounding region. During the $1800^{\prime} \mathrm{s}$, gold and silver mining were important activities, and human population was several times as large as it is now. With the decline of mining in the early 1900 's, population also decreased until recent growth from recreationoriented development. The area is still one of the most sparsely populated regions of California. Mono 'County is the third least-populated county in California with a total estimated population (1977) of 7,500 people in 3,028 square miles. Counties immediately to the north and south (Alpine and Inyo, respectively) have even lower population densities. 
Recreation forms the base of the existing economy. Mamnoth Lakes is a yearround resort and the largest population center in the KGRA. Resident population is about 3,000 to 4,000 people, but this number may swell to 20,000 on peak recreation weekends. Skiing is the most popular winter recreation, and Mammoth Mountain is one of the largest skiing centers in the United States. Fishing, camping, and hiking are popular sumer activities. Nearly five million recreation visitor days were recorded for Inyo National Forest in 1975, fourth highest of any National Forest.

The foregoing introduction was intended to provide a brief general overview of the KGRA, while the accompanying photographs illustrate some of its general features. The following chapters contain more detailed information about these topics and their relation to the potential development of geothermal energy.

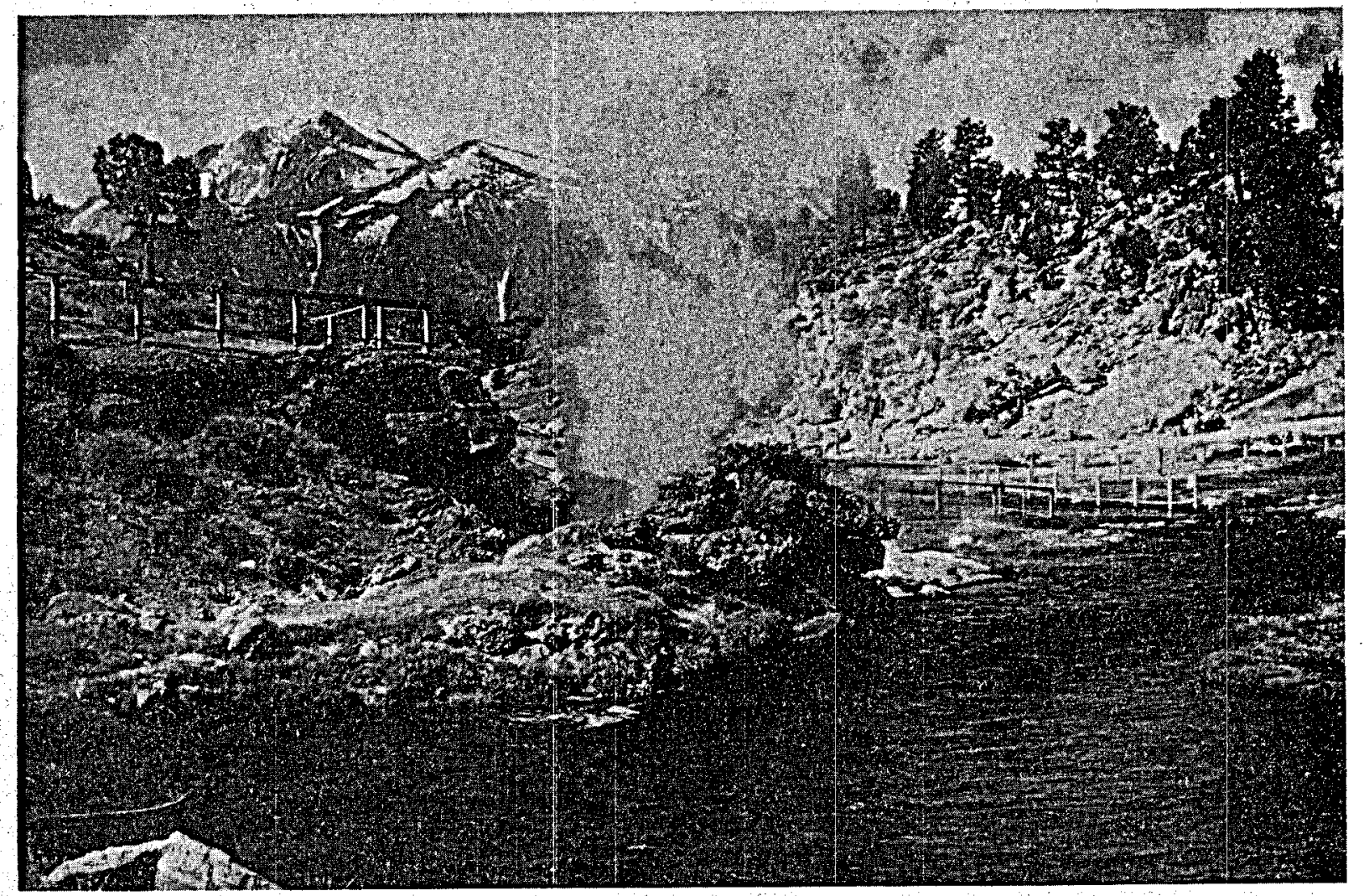

Fumaroles along Hot Creek 


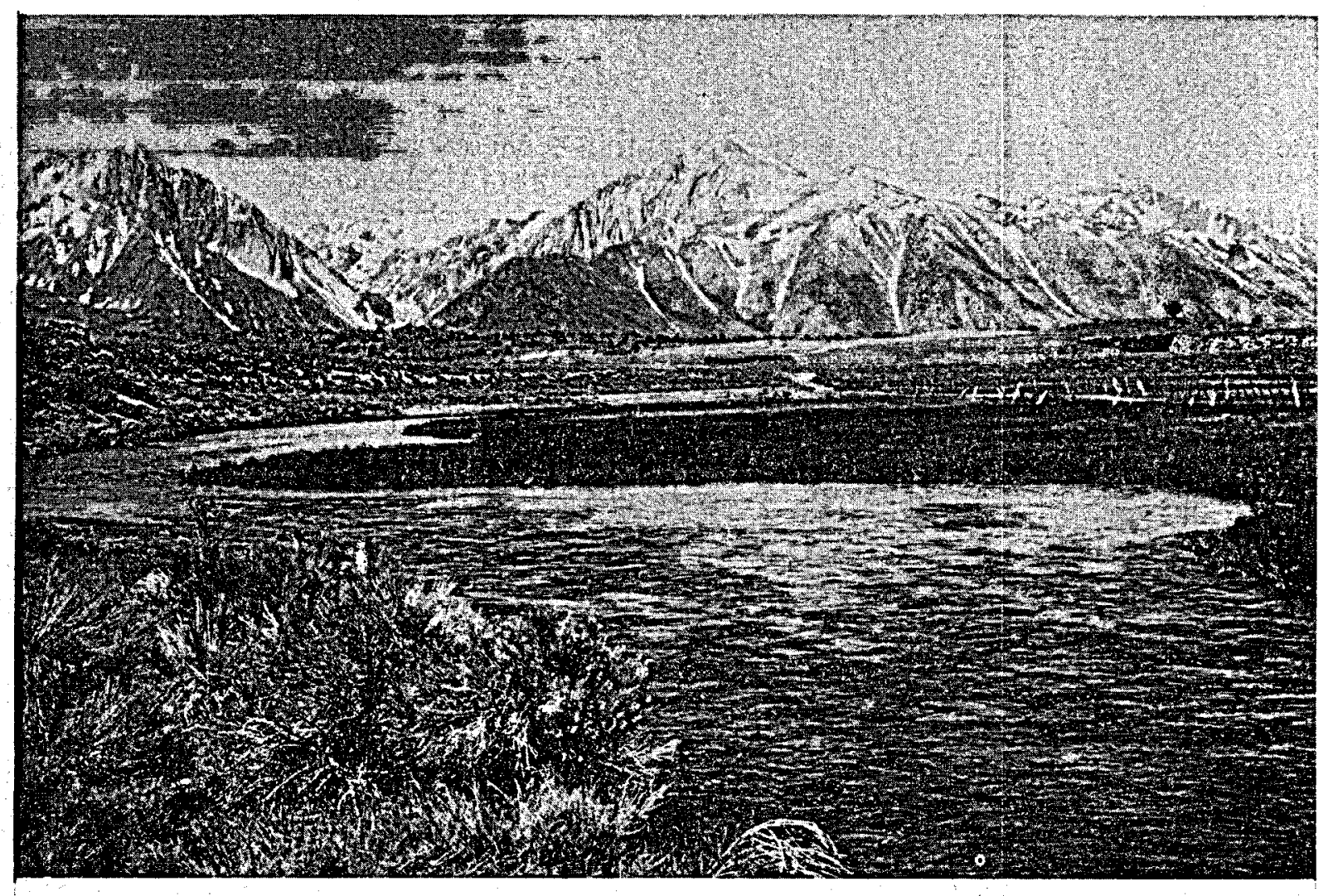

Lower Hot Creek and the Sierra Nevada escarpment

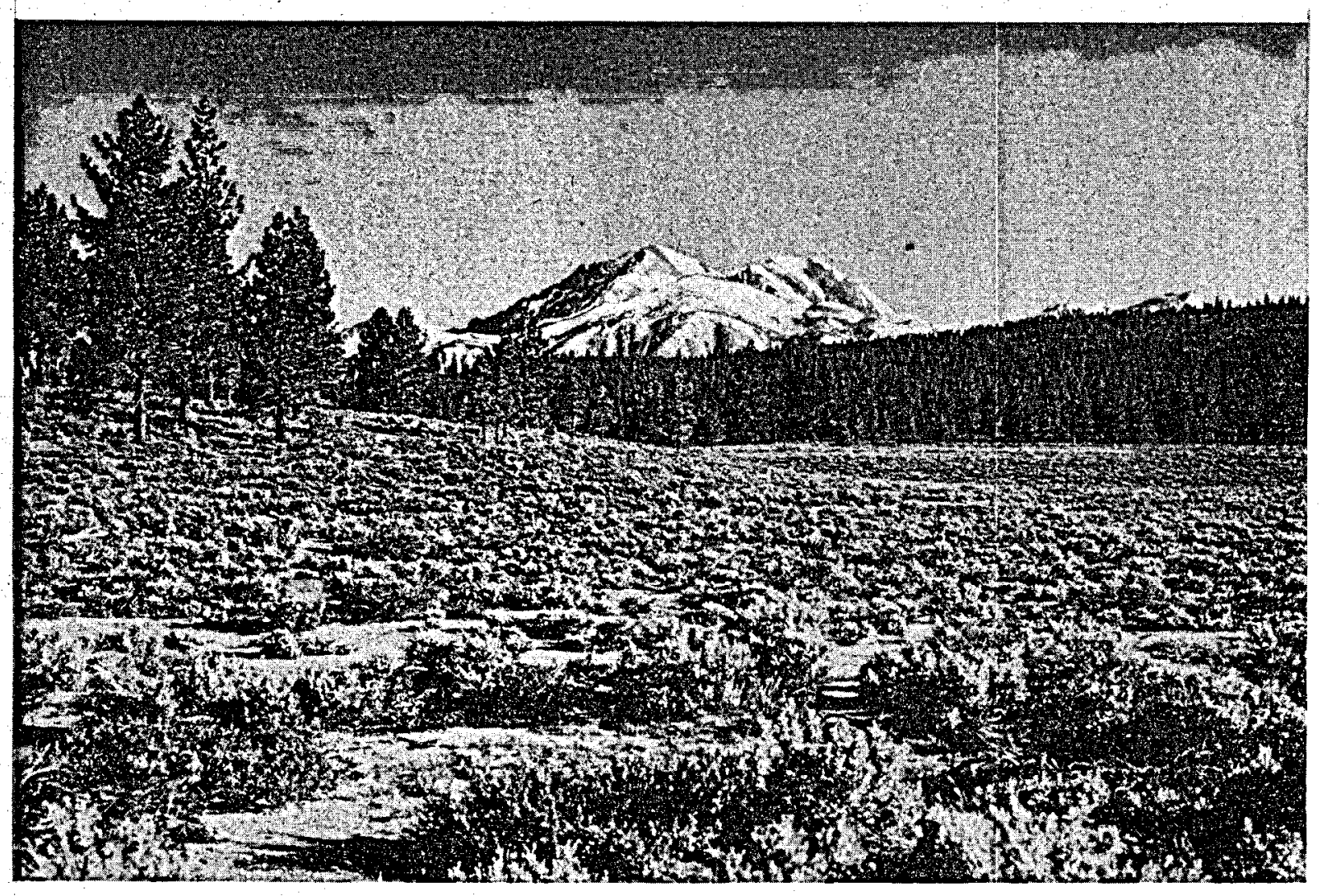

Sagebrush and Jeffrey pine habitat 


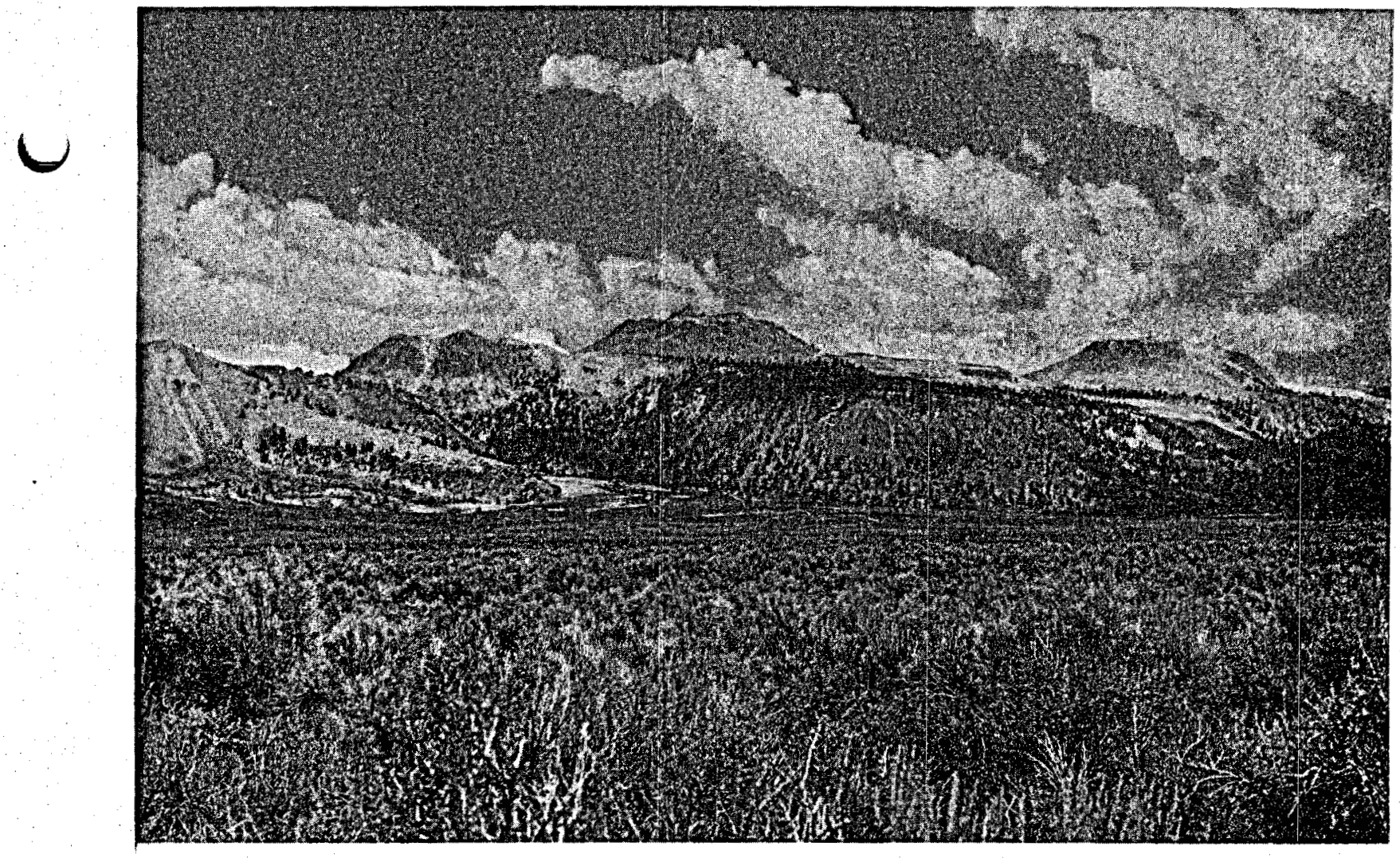

View east toward Mono Craters

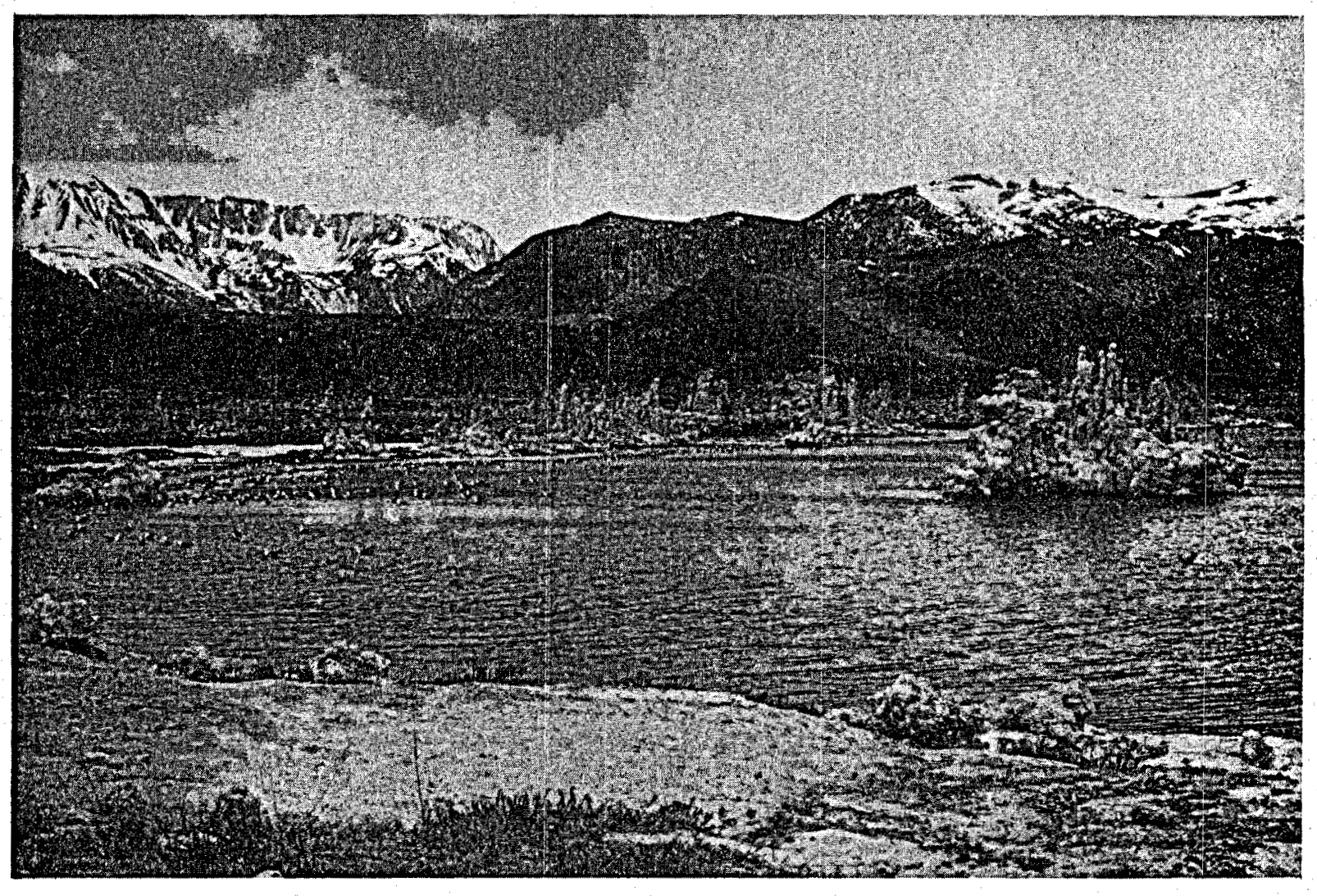

Tufa towers at the western end of Mono Lake 

Chapter 2

GEOTHERMAL ENERGY DEVELOPMENT IN MONO-LONG VALLEY KGRA

\section{Carl L. Strojan}

Laboratory of Nuclear Medicine and Radiation Biology

University of California, Los Angeles 


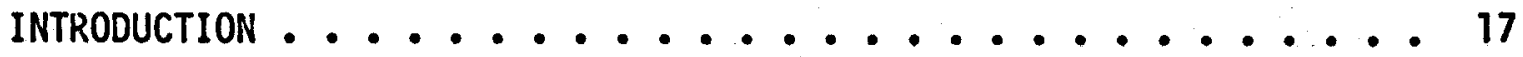

LEASING AND DRILLING HISTORY ........................ 18

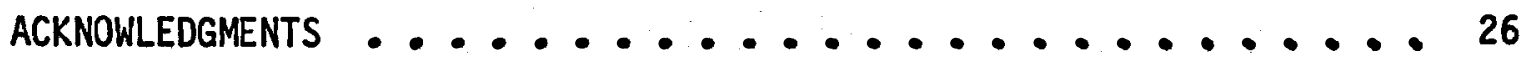

REFERENCES CITED ...................... 27

\section{LIST OF TABLES}

1. Estimates of Potential Electrical Energy in the Geothermal Reservoir of Mono-Long Valley KGRA ........ 17

2. Summary Characteristics of Privately-Drilled Geothermal Wells in Mono-Long Valley KGRA ............ 19

3. Average Concentrations of Chemical Constituents of Geothermal Well Fluids in Long Valley $(\mathrm{mg} / \mathrm{l}) \ldots . . . . .21$

4. Highest Bidder and Runner-up for Bureau of Land Management Geothermal Leases in Mono-Long Valley KGRA on

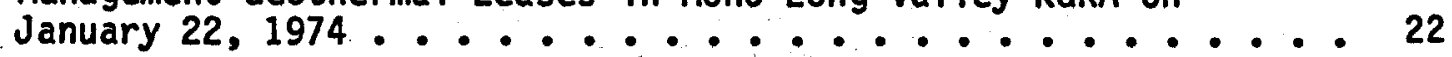

\section{LIST OF FIGURES}

1. Locations of Existing and Proposed Commercial Geothermal Wells in Mono-Long Valley KGRA ............. 20

2. Locations of Geothermal Lease Units and "Grandfather Lands" Subject to Conversion Rights under Section 4 of the Geothermal Steam Act of 1970

3. Drilling Rig at Republic Geothermal Inc.'s Lease Unit in Long Valley

4. Geothermal Space-heating Demonstration Plant at Casa Diablo. 


\section{INTRODUCTION}

The Mono-Long Valley geothermal reservoir is a water-dominated system. As such it can be expected to differ physically and chemically from vapordominated systems such as The Geysers region in northern California (White et a1. 1971). A model of the hydrothermal system of Long Valley has recently been published by Sorey et al. (1978). Their results will be discussed in other sections of our report.

Long Valley reservoir temperatures at depth have been estimated from the geochemistry of hot-spring waters at $210^{\circ} \mathrm{C}$ to $280^{\circ} \mathrm{C}\left(410^{\circ} \mathrm{F}\right.$ to $536^{\circ} \mathrm{F}$ ) (Sorey et a1. 1978). Geothermal waters are thus hot enough for space heating or electricity production, and both alternatives have been considered. A pilot space-heating project is being tested in Long Valley (Sims and Racine 1977), while Fredrickson (1977) has described scenarios for electricity production assuming a $2000 \mathrm{MW}_{\mathrm{e}}$ potential for Long Valley.

One of the major geothermal uncertainties in Mono-Long Valley is the size of the resource. Several estimates of potential geothermal electric capacity have been published for the KGRA (Table 1), but these must be regarded as tentative and speculative." The four most important factors affecting these resource estimates are reservoir volume, recoverability, temperature, and technology-economics (Muffler and Williams 1976). The 1975 U.S. Geological Survey estimate of about $6000 \mathrm{MW}$ for 30 years was the highest for any KGRA in the United States. This estimate was recently revised downward to 2100 MWe for 30 years (Muffler 1979). Corresponding thermal energy estimates were lowered from $230 \times 1018$ joules to $78 \times 1018$ joules. The primary reason for these changes was a 225 to $82 \mathrm{~km}^{2}$ reduction in reservolr area used in making calculations. This in turn was based on new information from commercial drilling and U.S. Geological Survey research. In spite of these revisions, Long Valley is still one of the largest geothermal reservoirs in the United States.

\section{TABLE 1}

ESTIMATES OF POTENTIAL ELECTRICAL ENERGY IN THE GEOTHERMAL RESERVOIR OF MONO-LONG VALLEY KGRA

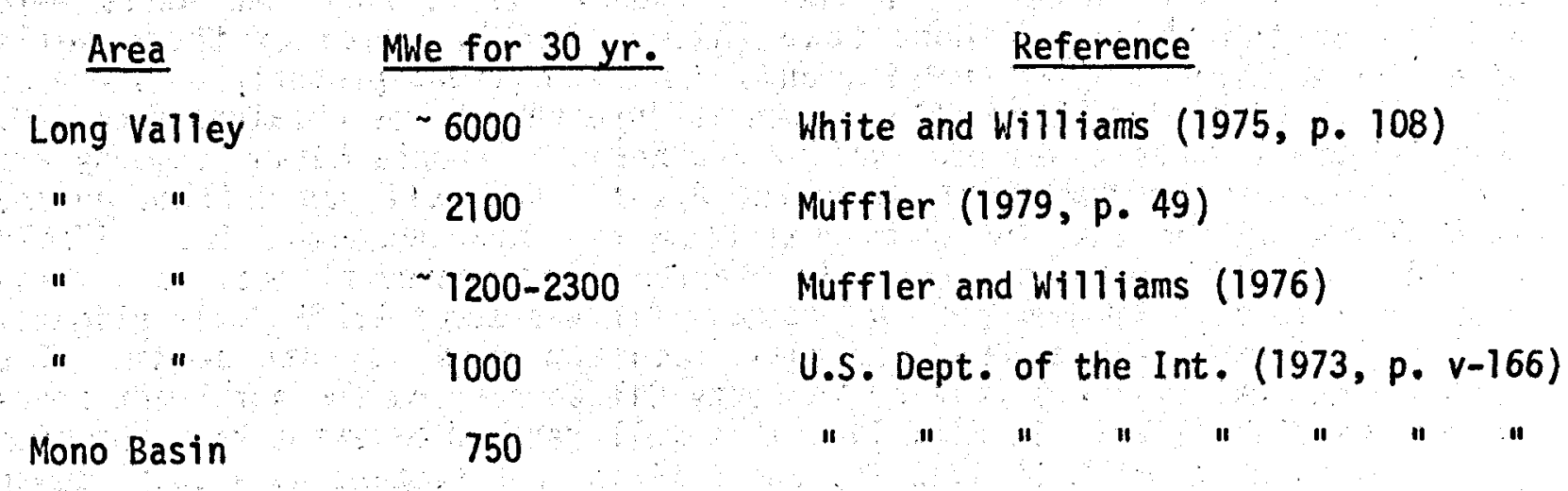




\section{LEASING AND DRILLING HISTORY}

Interest in developing the geothermal resources of Mono-Long Valley for electricity can be traced at least to the early 1900's (Anderson and Hall 1973), but no actual drilling occurred until 1959. Three potential regions for development exist within the KGRA: Mono Lake, Mono Craters, and Long Valley (Fredrickson 1977). Of these, Long Valley is believed to have the greatest potential. To date, exploration has occured only around Mono Lake and in Long Valley.

The following summary of the history of geothermal development is based largely on information previously published by McNitt (1963), California Department of Water Resources (1967), Axtell (1972), Sims and Racine (1977), and Smith and Rex (1977). Magma Power Company and its subsidiary, Magma Energy, Inc., claim grandfather rights to geothermal leases on about 15,000 acres in Long Valley. Magma Power Company also owned about 90 acres of land at the turnoff from U.S. Highway 395 to Mammoth Lakes in the Casa Diablo region of Long Valley, on which it drilled nine geothermal wells between 1959 and 1962. This property subsequently was transferred to its subsidiary, Magma Energy Inc. Magma also drilled a tenth well about three miles east of Casa Diablo. These were relatively shallow wells, with a maximum depth of about 1,063 ft (Table 2, Fig. 1). Maximum temperature in the wells, which discharged a mixture of saturated steam and hot water, was about $356^{\circ} \mathrm{C}$. Pressures in four tested wells ranged from 7.5 to 39 pounds per square inch gauge (psig), steam production ranged from 19,000 to $69,300 \mathrm{lb} / \mathrm{hr}$, and water flow ranged from 233,500 to $473,000 \mathrm{lb} / \mathrm{hr}$ (McNitt 1963). Chemical analyses of well fluids are: shown in Table 3. Chemical concentrations are generally much lower than from other geothermal hot-water reservoirs (Sabadell and Axtmann 1975, Case et al. 1977, p. 3-149). Non-condensable gases consisted of 98.25\% $\mathrm{CO}_{2}$ and $1.75 \% \mathrm{H}_{2} \mathrm{~S}$ by volume. An infrared spectrum indicated no other gases present (McNitt 1963).

Although these wells were drilled for the eventual purpose of generating electricity, they were never brought into production. Major problems involved the disposal of geothermal waste waters relatively high in arsenic, boron and fluoride concentrations, and flashing in the wells which caused them to plug up after a short flowing period. Magma has since developed a process which prevents such flashing.

No further drilling occurred in the KGRA until 1971, when two wells were drilled on the shores of Mono Lake (Axtell 1972). Both of these wells were drilled directionally from Bureau of Land Management property on shore to state lands under Mono Lake after a special use permit was obtained from BLM. Some financial support was provided by Southern Cal ifornia Edison Company and the Los Angeles Department of Water and Power. One well was drilled on the south shore of the lake by Geothermal Resources International, Inc. (Table 2, Fig. 1). Drilling was stopped in granite gneiss basement rock at a total depth of $4110 \mathrm{ft}$. Maximum recorded temperature was about 1300F, only slightly higher than what would have normally been expected at that depth. The second Mono Lake well was drilled by Getty 0il Company on the northwest shore near Black Point (Table 2, Fig. 1). This well reached basement rock (biotite grandiorite) at a depth of $1740 \mathrm{ft}$, and drilling was stopped at a total depth of $2442 \mathrm{ft}$. 
TABLE 2

SUMMARY CHARACTERISTICS OF PRIVATELY-DRILLED GEOTHERMAL WELLS IN MONO-LONG VALLEY KGRA

Fig. 1 Key

1 Mammoth No. 1

2 No. 2

3 Endogenous No. 1

4 "No. 2

5

6

7

8

9

10 Chance No. 1

11 "State PRC 4397.1" 1

12 "State PRC 4572.1" 23-1

13 "Long Valley" No. 66-29

(14) Proposed Casa Diablo

(15)

(16)

\section{Total}

Year Depth Max Temp

Drilled (ft)

$1959 \quad 1,063$

22 unknown

630

352

810

345

570

342

513 unknown

405

756

670

1961

805

1971

4,110

130

2,442

136

GRI, Inc.

$"$

1976

6,920

162

Operator

Magma Power Co.

I I

II 11

I

II, I

II II

I1

n $n$

II 11

" 11 "

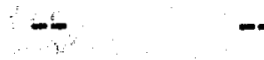

Source: McNitt (1963), California Department of Water Resources (1967), Axtell (1972), Lewis (1974), Sims and Racine (1977), Smith and Rex (1977), and Woodward-Ciyde Consultants (1977). 


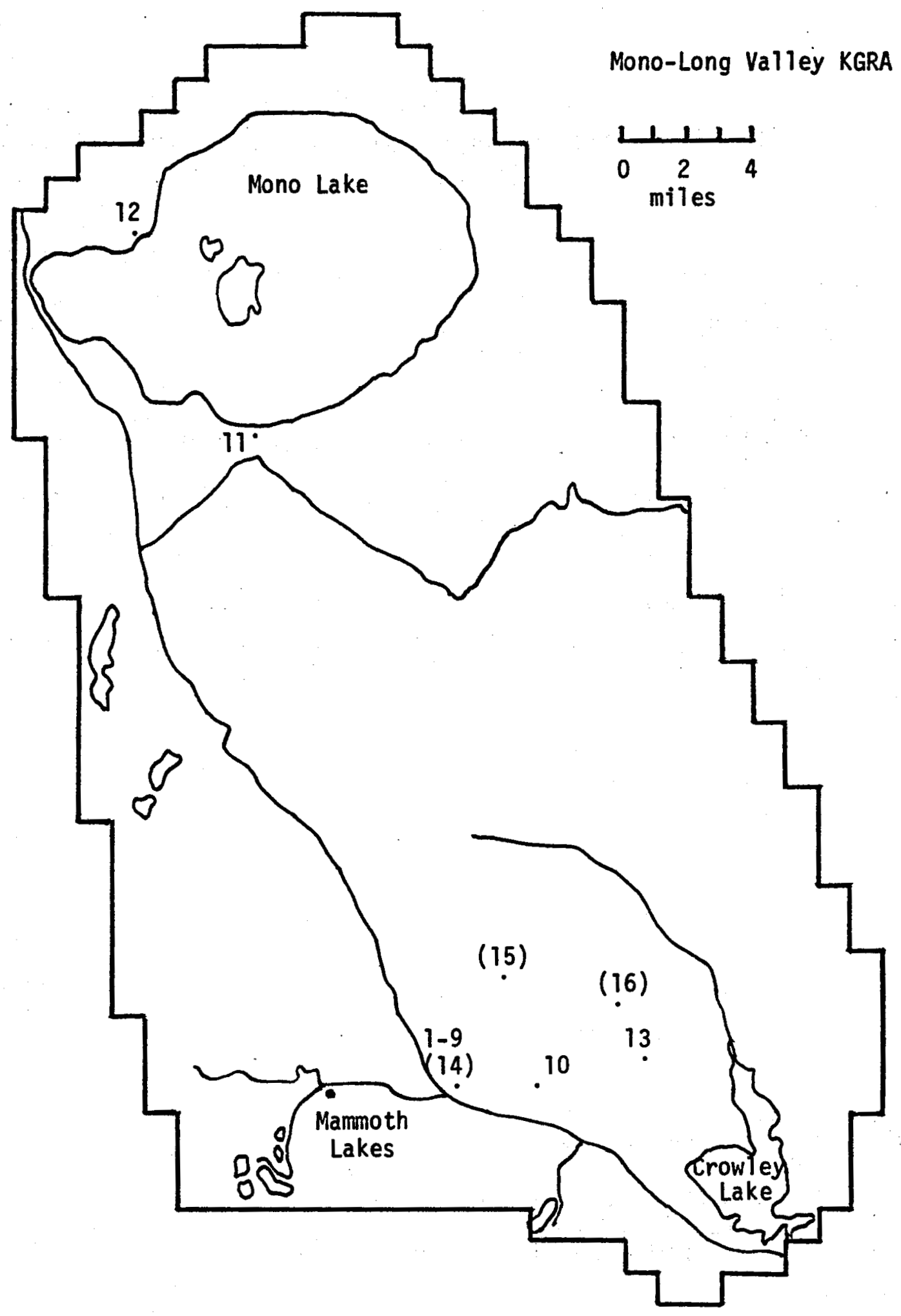

Figure 1. Locations of existing and proposed commercial geothermal wells in Mono-Long Valley KGRA. Proposed wells are shown in parentheses. See Table 2 for identification of numbers. Locations are taken from Axtell (1972), Woodward-Clyde Consultants (1977) and California Division of 0il and Gas (1978). 
TABLE 3

AVERAGE CONCENTRATIONS OF CHEMICAL CONSTITUENTS OF GEOTHERMAL WELL FLUIDS IN LONG VALLEY (mg/1)

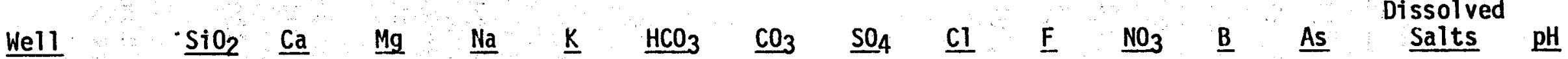
$\begin{array}{llllllllllllllllllllllll}\text { Mammoth No.2 } & - & 51 & 0 & 360 & 38 & 549 & 0 & 120 & 258 & 11 & 0.8 & 11 & 1.9 & 1380 & 6.8\end{array}$

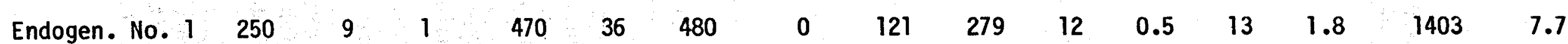

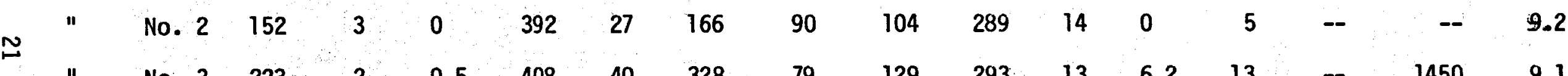

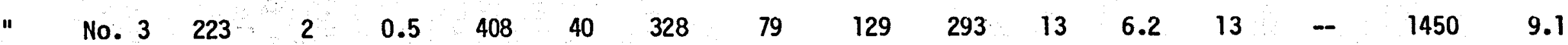
" No. $4 \begin{array}{llllllllllllllllll} & 2 & 200 & 4 & - & 308 & 32 & - & - & 96 & 227 & 20 & -- & 11 & 0.2 & 1500 & 6.5\end{array}$ $\begin{array}{lllllllllllllllllllll}1 & \text { No. } 5 & 121 & 2 & 0.7 & 428 & 38 & 344 & 92 & 122 & 291 & 16 & 0.4 & 11 & 1.9 & 1463 & 9.2\end{array}$

$\begin{array}{llllllllllllllllllllll} & \text { No. } & 7 & 105 & 0.5 & 0.5 & 298 & 49 & 329 & 92 & 175 & 178 & 7 & 2.5 & 7 & 3.0 & 1425 & 9.1\end{array}$

Source: Averages were calculated from data presented by Lewis (1974) 
TABLE 4

HIGHEST BIDDER AND RUNNER-UP FOR BUREAU OF LAND MANAGEMENT GEOTHERMAL LEASES IN MONO-LONG VALLEY KGRA ON JANUARY 22, 1974

\begin{tabular}{|c|c|c|c|c|}
\hline Unit $^{\mathrm{a}}$ & Acres & Company & $\underline{B i d}$ & Cost/Acre \\
\hline \multirow[t]{2}{*}{1} & $1,815.08$ & Chevron 0il Company & $\$ 18,459.36$ & $\$ 10.17$ \\
\hline & & GRI, Inc. & $9,080.00$ & 5.00 \\
\hline \multirow[t]{2}{*}{2} & $1,895.21$ & Getty 0 il Company & $98,592.00$ & 52.02 \\
\hline & & Cherron 0il Company & $25,073.63$ & 13.23 \\
\hline \multirow[t]{2}{*}{3} & $1,772.70$ & Republic Geothermal, Inc. & $515,767.07$ & 209.95 \\
\hline & & Union $0 i 1$ Company & $281,504.76$ & 158.80 \\
\hline 4 & $1,883.07$ & No bid received & & \\
\hline 5 & $2,308.55$ & $" 1$ & & \\
\hline 6 & $1,762.83$ & " " " & & \\
\hline 7 & $2,276.59$ & " " & & \\
\hline
\end{tabular}

alocations are shown in Fig. 2.

Source: California Division of 0il and Gas (1974)

In January 1974 the Bureau of Land Management offered for lease 7 units totalling 13,714 acres. Four of these units near Mono Lake (Nos. 4-7) received no bids, possibly because of the earlier drilling results described above. The additional three blocks, in Long Valley, were leased respectively to Cherron 0il Company, Getty 0il Company (operating with Mono Power Co., a subsidiary of Southern California Edison), and Republic Geothermal, Inc. (operating with the City of Burbank). Bidding for the seven BLM units is summarized in Table 4.

Under conversion provisions of the Geothermal Steam Act of 1970, GRI, Inc. claimed grandfather rights to units 1 and 2, and matched the highest bid for each. No drilling has occurred to date on unit 1. Getty 0il Company challenged the claim on unit 2, and lease rights to the unit are still under litigation. GRI, Inc. also claims grandfather rights to geothermal leases on about 940 acres in Long Valley.

Drilling occurred in 1975-1976 on the uncontested Republic-City of Burbank lease (unit 3 ). Six temperature-gradient test holes were initially drilled on the lease site, ranging in depth from 232 to $808 \mathrm{ft}$ (Smith and Rex 1977). 


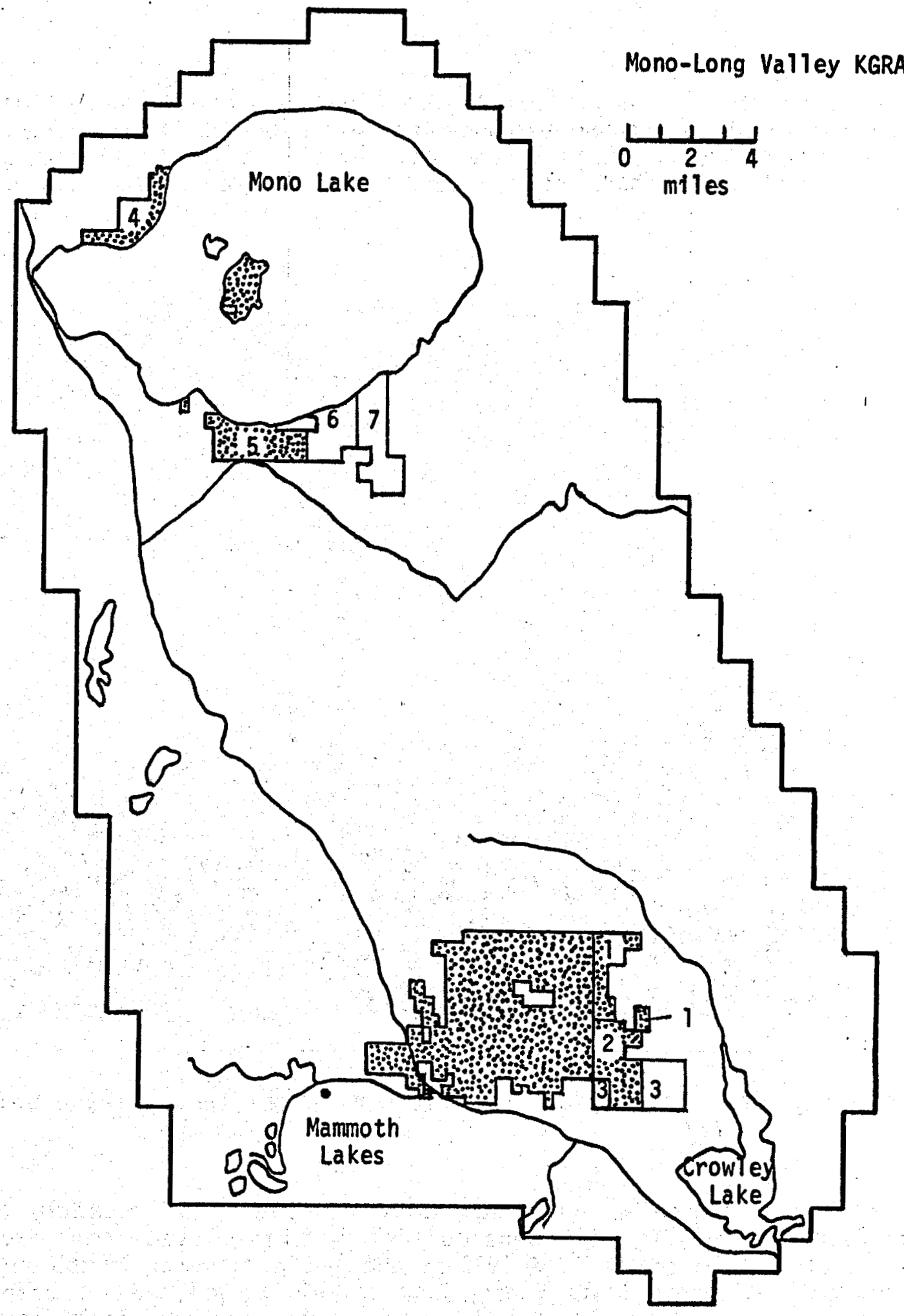

Figure 2. Locations of geothermal lease units (numbered areas) and "grandfather lands" subject to conversion rights under Section 4 of the Geothermal Steam Act of 1970 (stippled areas). See Table 4 and text for identification of lessees. Locations are taken from U.S. Department of the Interior (1973, map) and California Division of 011 and Gas (1973, p. 12). 
One deep test well was drilled in 1976 (Table 2, Figs. 1 and 3). It reached a depth of $6920 \mathrm{ft}$ without encountering basement rock or high enough temperatures to warrant further exploration. Shortly after this venture, Republic transferred their share of the Long Valley lease to the City of Burbank.

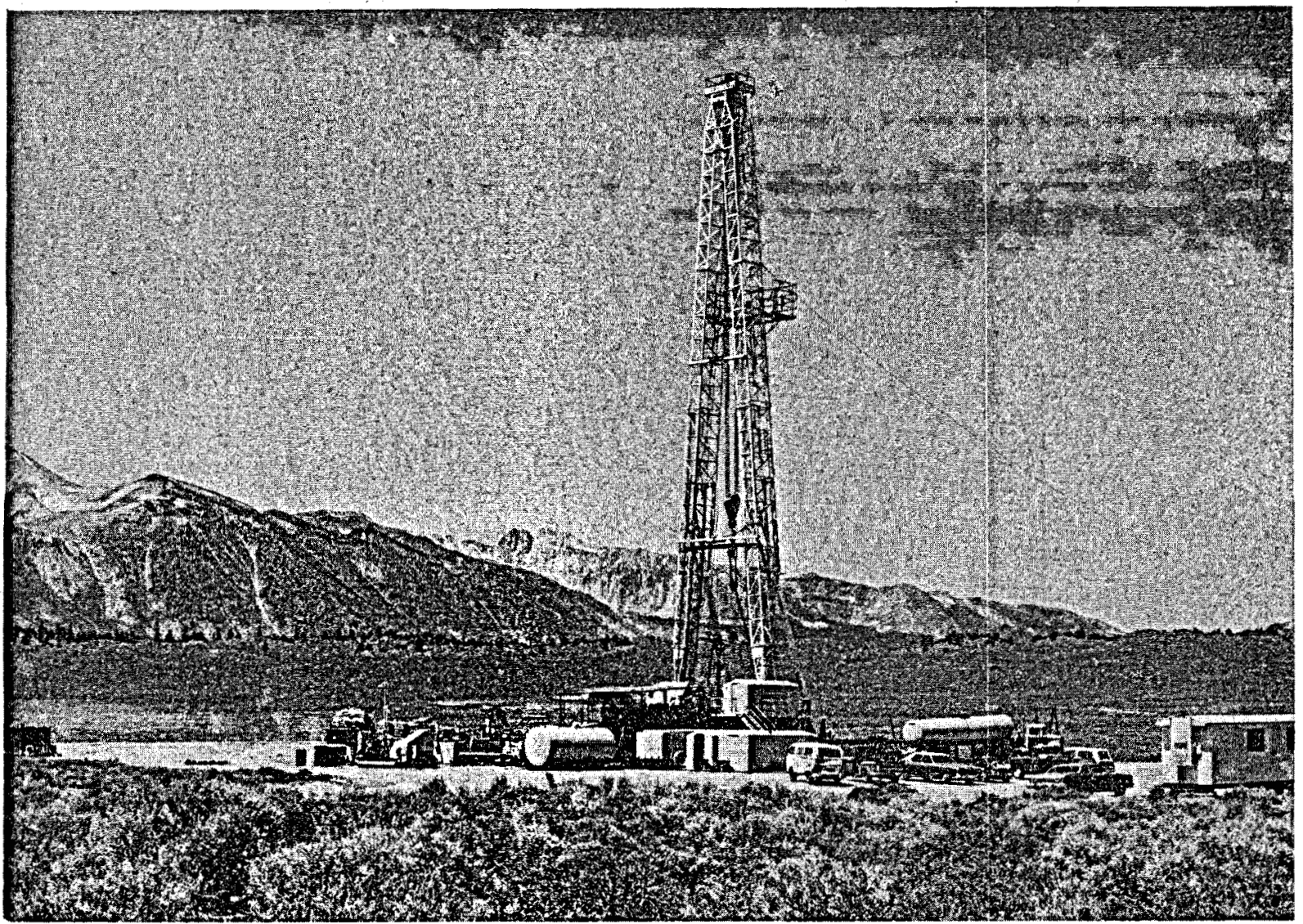

Figure 3. Drilling rig at Republic Geothermal Inc.'s lease unit in Long Valley.

A geothermal space-heating demonstration plant has recently been built at Casa Diablo (Fig. 4). Construction of this closed-loop pilot project was completed in the fall of 1977 by the Ben Holt Company, with major funding from the California State Energy Commission. Its purpose has been to gather test data and to demonstrate the economic and technological feasibility of geothermal space-heating for the Mammoth Lakes area, where about 85\% of all space and water heating is now done by electrical resistance. Descriptions of the project have been set forth by Sims and Racine (1977) and Racine (1978). The plan, if fully implemented, would provide hot-water heating for homes and businesses in the Mammoth Lakes area, and also be used to melt snow on roads and walkways. The source of geothermal fluids for the project is Magma Energy Inc.'s Endogenous No. 2 well, which the company reopened. Testing has continued through the winter of 1978-79. 


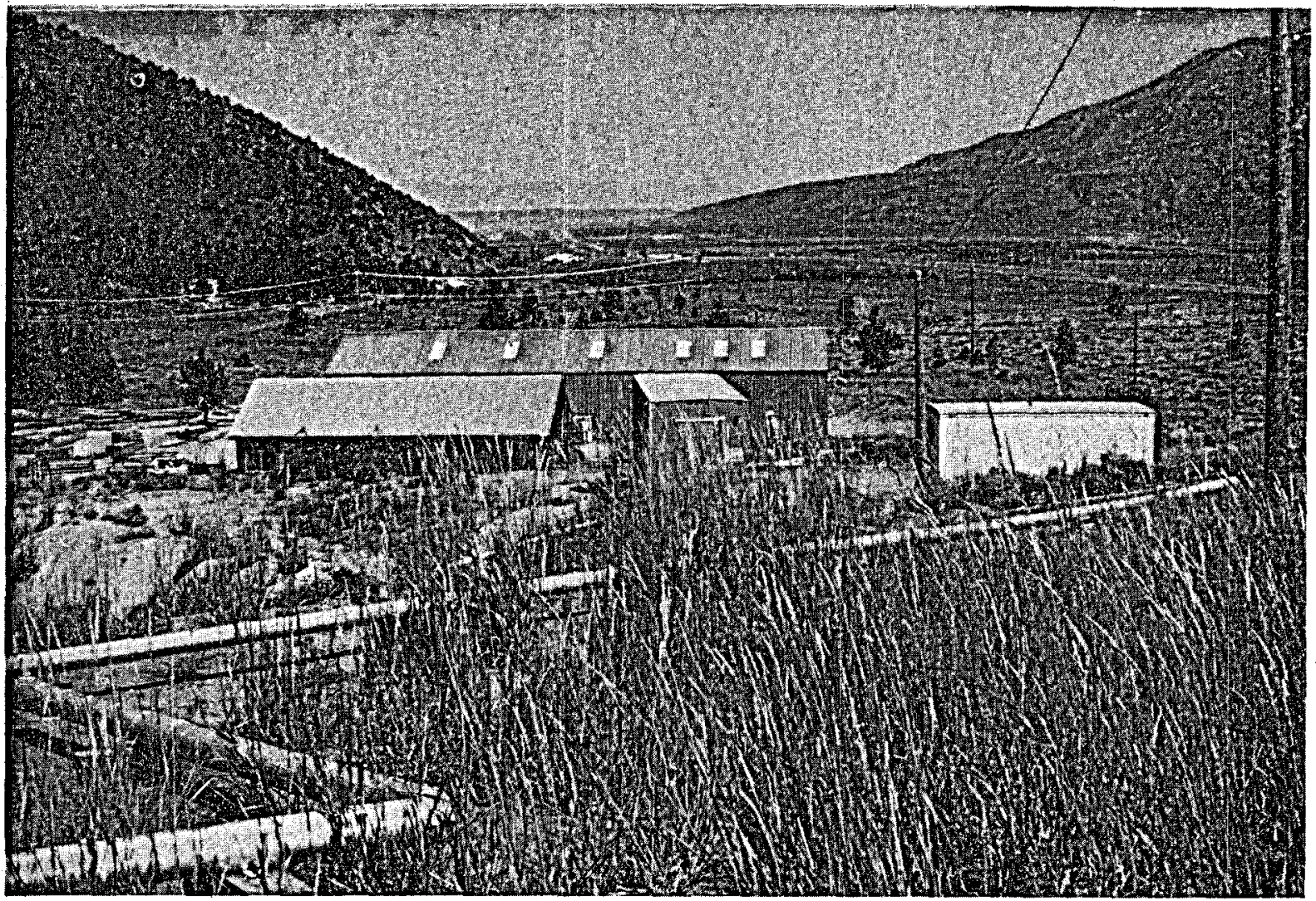

Figure 4. Geothermal space-heating demonstration plant at Casa Diablo.

Union $0 i 1$ Company received permission from Mono County in 1977 to drill two exploratory wells on private land in Long Valley. Union will also act as operator for a third well to be drilled on Magma Energy Inc. 's property. Locations of the three proposed wells are near the so-called "grandfather lands" in Long Valley. One site is at Casa Diablo on Magma Energy Inc.'s property, the second is in the clay pit, and the third is on the Cashbaugh ranch (Fig. 1, Nos. 14, 15 and 16 respectively). This project is discussed in the Environmental Data Statement prepared by Woodward-Clyde Consultants (1977). Drilling may begin in 1979 at Casa Diablo and the clay pit, but plans for the Cashbaugh site have been postponed (Jim Vantine, personal comunication).

In addition to the above commercially-oriented ventures, the U.S. Geological Survey drilled a number of test wells in $1972-1973$ as part of their study of Long Valley. Lewis (1974) included physical and chemical data for 47 of these U.S.G.S. wells. They ranged in depth from 6 to $107 \mathrm{ft}$ and were drilled for the purpose of obtaining geologic and hydrologic data. Sass et al. (1974) reported data for six deeper wells near Long Valley--three of which were within the KGRA. The three KGRA wells ranged in depth from 620 to $1000 \mathrm{ft}$ and had maximum temperatures ranging from about 50 to $171 \mathrm{~F}^{\mathrm{F}}$. Additional data for the $1000 \mathrm{ft}$ deep well were reported by Lewis (1975). 
Further drilling and exploration are contingent upon U.S. Forest Service and Bureau of Land Management leasing policies. The U.S. Forest Service owns most of the land in Long Valley which is considered to have the greatest potential geothermal resource. The Forest Service has not leased any of this land to date, nor is it likely to do so until completion of an acceptable regional land management $\mathrm{plan}$ and environmental assessment report. A "Draft environmental statement of land management alternatives for the Mamnoth-Mono Planning Unit" was completed and distributed for public corment in July 1978. It contained six alternative land management plans for the Mammoth-Mono Planning Unit which includes all U.S. Forest Service lands in Mono-Long Valley KGRA. The Forest Service identified "preferred alternative" included 26,330 acres of Inyo National Forest for possible geothermal leasing. These acres included the so-called "grandfather lands" in Long Valley as well as additional surrounding land. Leasing could occur sometime in 1979.

The foregoing paragraphs briefly summarize past and present geothermal development activities in Mono-Long Valley. These activities involve numerous local, state and federal agencies in planning and permitting procedures. Table 27 (Chapter 8) identifies these agencies, while a thorough discussion of their responsibilities is presented by the Jet Propulsion Laboratory (1976, Appendix). Because of land ownership patterns, most of the agencies are at the state and federal level. Mono County has no specific ordinances regulating geothermal energy development.

\section{ACKNOWLEDGMENTS}

Preparation of this chapter was aided by information and/or critical review provided by the following individuals: Joseph Aidlin, Richard Campbell (The Ben Holt Company), Richard Foss (Magma Power Co.), Doug Gall (GRI, Inc.), Charles MCDonald (U.S. Forest Service), Greg Simay (City of Burbank), Warren Smith and James Vantine (Union 0il Company), Terry Thomas (Republic Geothermal, Inc.) and Syd Willard (California Energy Commission).

I thank Steve Lipshie for permitting use of his photograph in Figure 3. 
Anderson, D. N., and B. A. Hall (eds.). 1973. Geothermal exploration in the first quarter century; a collection of papers illustrating early interest in geothermal development, including reports prepared for the Southern Sierras Power Company by H. N. Siegfried in 1925. Davis, Calif., Geothermal Resources Council, Special Report No. 3, 191 p.

Axte11, L. 1972. Mono Lake geothermal wells abandoned. Cal if Geol. 25(3): 66-67.

California Department of Water Resources. 1967. Investigation of geothermal waters in the Long Valley area, Mono County. $141 \mathrm{p} .+7 \mathrm{pl}$.

California Division of 011 and Gas. 1973. Geothermal Hot Line 3(7):11-14.

California Division of 011 and Gas. 1974. Geothermal Hot Line 4(7):2.

California Division of 011 and Gas. 1978. Geothermal map G1-1, Casa Diablo, scale $1: 20,000$.

Case, G. D., T. A. Bertolli, J. C. Bodington, T. A. Choy, and A. V. Nero. 1977. Health effects and related standards for fossil-fuel and geothermal power plants. Vol. 6 of health and safety impacts of nuclear, geothermal and fossil-fuel electric generation in California. University of California, Lawrence Berkeley Laboratory Report LBL-5287, ca. 427 p.

Fredrickson, C. D. 1977. Analysis of requirements for accelerating the developrient of geothermal energy in California. JPL Publication 77-63. Pasadena, Jet Propulsion Laboratory, California Institute of Technology, ca. 158 p. +3 App.

Jet Propulsion Laboratory, California Institute of Technology. 1976. Geothermal energy resources in California: Status Report. JPL Document 5040-25; Rev. A. Pasadena, Calif., Jet Propulsion Laboratory, 211 p. + App.

Lewis, R. E. 1974. Data on wells, springs, and thermal springs in Long Valley, Mono County, California. U. S. Geol. Survey, open-file report, $52 \mathrm{p}$.

Lewis, R. E. 1975. Data from a 1,000 ft. (305 metre) core hole in the Long Valley caldera, Mono County, California. U. S. Geol. Survey open-file report, $16 \mathrm{p}$.

McNitt, J. R. 1963. Exploration and development of geothermal power in California. California Division of Mines and Geology, Special Report 75, $44 \mathrm{p}$. 
Muffler, L. J. P. (ed.) 1979. Assessment of geothermal resources of the United States--1978. U.S. Geol. Survey Circular 790, 163 p.

Muffler, L. J. P., and D. L. Williams. 1976. Geothermal investigations of the U. S. Geological Survey in Long Valley, California, 1972-1973. J. Geophys. Res. 81:721-724.

Racine, W. C. 1978. Economics of geothermal space/water heating in Mammoth Lakes, California. In Direct utilization of geothermal energy: A symposium, pp. 57-59. Davis, Calif., Geothermal Resources Council, CONF-780133, 145 p.

Sabadell, J. E., and R. C. Axtmann. 1975. Heavy metal contamination from geothermal sources. Environ. Health Perspect. 12:1-7.

Sass, J. H., S. H. Lachenbruch, and R. J. Munroe. 1974. Thermal data from heat-flow test wells near Long Valley, California. U. S. Geol. Survey open-file report $74-1090,43 \mathrm{p}$.

Sims, A. V., and W. C. Racine. 1977. Feasibility of geothermal space/ water heating for Mammoth Lakes Village, California. Final report for period September 1976-September 1977. Prepared for the Department of Energy. Pasadena, Calif., The Ben Holt Co., 123 p.

Smith, J. L., and R. W. Rex. 1977. Drilling results from the eastern Long Valley caldera. In Energy and mineral resource recovery, pp. 529-540. U. S. Dept. of Energy CONF-770440.

Sorey, M. L., Lewis, R. E., and F. H. 01msted. 1978. The hydrothermal system of Long Valley caldera, California. U. S. Geol. Survey Prof. Paper 1044-A, $60 \mathrm{p}$.

U. S. Department of the Interior. 1973. Final environmental statement for the geothermal leasing program. Vol. II. Washington, D. C. Government Printing Office.

White, D. E., L. J. P. Muffler, and A. H. Truesdel1. 1971. Vapor-dominated hydrothermal systems compared with hot-water systems. Economic Geology $66: 75-97$.

White, D. E., and D. L. Williams (eds.). 1975. Assessment of geothermal resources of the United States--1975. U. S. Geol. Survey Circular $726,155 \mathrm{p}$.

Woodward-Clyde Consultants. 1977. Exploratory geothermal well drilling operations at Long Valley, California. Environmental data statement prepared for Union 0il Company of California. San Francisco, WoodwardClyde Consultants, ca. 78 p. + App. 


\section{Chapter 3}

\section{GEOLOGY OVERVIEW}

Steven R. Lipshie

Department of Earth and Space Sciences

University of Cal ifornia, Los Angeles 
LIST OF TABLES AND FIGURES .............. 31

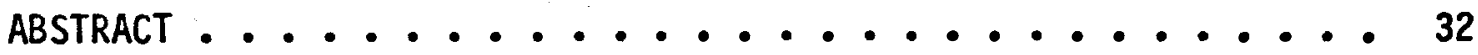

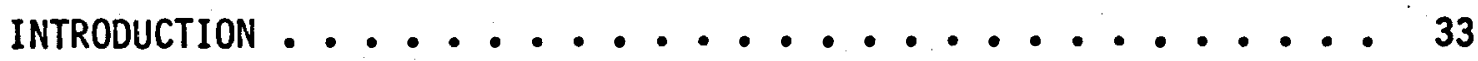

Physiography and Culture ................. 35

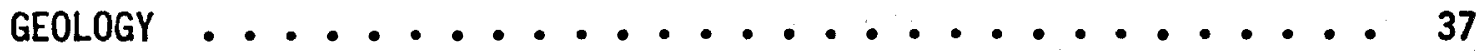

Pre-Quaternary Geology . . . . . . . . 37

Quaternary Geology of Long Valley Caldera ........ 41

Late Quaternary Geology of Northern Part of KGRA . . . . 43

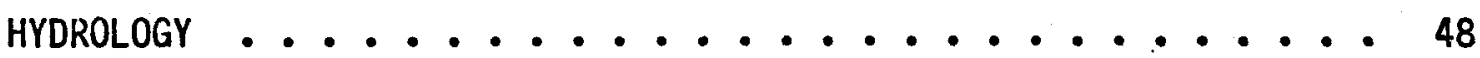

Surface Hydrology .................... 48

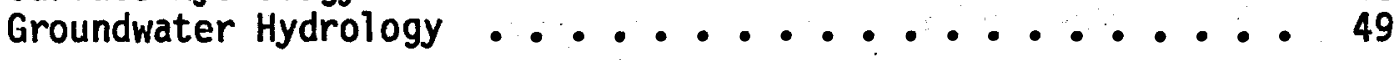

GEOLOGIC HISTORY ....................... 51

LIKELY AREAS FOR GEOTHERMAL DEVELOPMENT $\ldots \ldots \ldots$

MAJOR ENVIRONMENTAL ISSUES .............. 57

Seismicity ......................... 58

Microseismicity and Induced Seismicity ....... 58

Large Seismic Events ............. 59

Fault Activity .............. 60

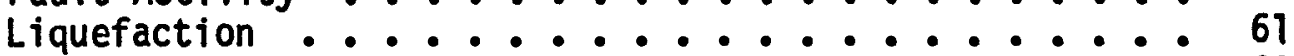

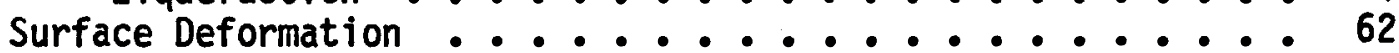

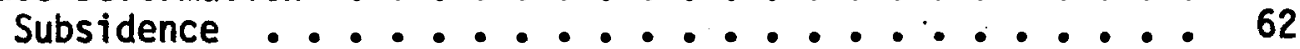

Horizontal Ground Displacement .......... 63

Slope Stability ................ 63

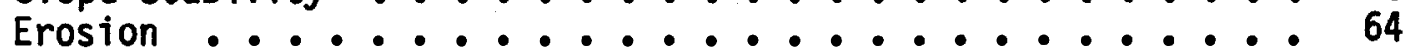

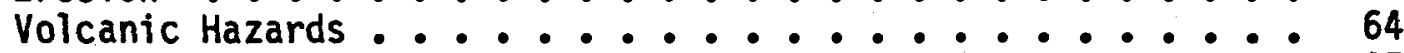

Effects of Development on Springs and Groundwater ..... 65

Effects of Development on Surface Flow ......... 66

Use of Local Water in Cool ing Towers .......... 66

DATA GAPS AND SOURCES, AND SUGGESTED PROJECTS ........ 67

Seismicity ....................... 67

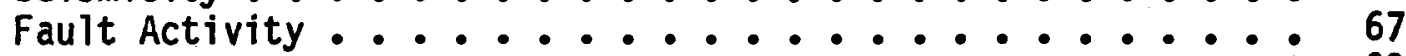

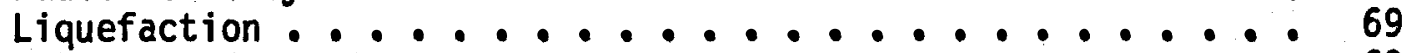

Surface Deformation .......................... 69

Slope Stability and Erosion .................... 69

Volcanic Hazards ........................ 69

Hydrologic Effects of Development .......... 70

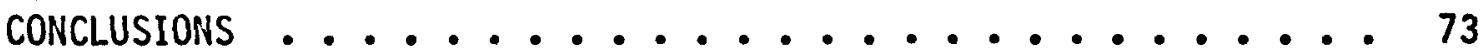


ACKNOWLEDGMENTS . . . . . . . . . . . . . 74

REFERENCES CITED . . . . . . . . . . . . 75

APPENDIX A: List of Geology Workshop Participants . . . . . . 82

APPENDIX B: Glossary of Geologic Terms .......... 83

APPENDIX C: Supplemental List of References . . . . . . 89

\section{LIST OF TABLES}

1. Geological Time Scale ................ 34

2. Simplified Classification Chart for Igneous Rocks .....40 40

3. Correlation of Glacial Sequences of the Eastern

Sierra Nevada, California.............. 44

4. Suggested Projects to Acquire Additional Data for

Use in Assessing Environmental Effects of

Geothermal Development ..............

68

5. Surmary of Environmental Geologic Issues ......... 72

\section{LIST OF FIGURES}

1. Index Map of Mono-Long Valley KGRA .......... 36

2. Generalized Geologic Map .............. 38

3. View Across Long Valley Caldera .............. 42

4. Schematic East-West Cross Section through Long Valley Caldera................

5. View North toward Volcanic Domes of Western Long Valley Caldera ................

6. Areal Distribution of Tephra 1 and Tephra 2 Layers

7. View East toward Rhyol ite Dome near North End of Mono Craters Chain ............. 55

8. Southernmost of Inyo craters .............. 56

9. Scarp of Hilton Creek Fault crossing Tioga Moraine along McGee Creek ............ 


\section{ABSTRACT}

The Mono-Long Valley KGRA consists of two principal lowland areas, Mono Basin in the north and the Long Valley caldera in the south, separated by the Glass Mountain Ridge-Bald Mountain highlands. By far the most likely area for geothermal development in the KGRA is the resurgent dome of the Long Valley caldera. The second most likely area for geothermal development is the Mono Craters-Pumice Valley region south of Mono Lake, but this area is unlikeIy to be developed for many years. In Long Valley, the course that any geothermal development takes depends on the size of the geothermal resources: electrical power generation if the resources are adequate, or local space heating if resources are limited. Further deep drilling will be needed in order to assess the size of the heat reservoir and evaluate its economic potential.

The environmental geology issues related to geothermal development which have the highest priorities for consideration are those issues that deal with the hydrologic effects of development: effects on springs, streams, and groundwater may be serious obstacles to geothermal development. Development-induced changes in seismic activity (particularly microseismicity) could also be a problem in the area, especially if the activity affects the subterranean plumbing of the hydrothermal reservoir. Geothermal production could be adversely affected by changes in the hydrothermal circulation. Other environmental geologic issues are not expected to be major problems during any geothermal development; these issues are subsidence, horizontal ground displacement, accelerated erosion, liquefaction, and slope instability. Volcanic hazards, although they cannot be evaluated reliably, are not expected to be affected by any geothermal development. Most environmental issues are related to geothermal production rather than to exploration. Analysis of some environmental issues, such as fault activity and large seismic events, would be the responsibility of the developers. Pre-development data collection is needed for some environmental geologic issues in order to establish data base levels to use in assessing the environmental effects of any development. 


\section{INTRODUCTION}

The purpose of this chapter of the Mono-Long Valley report is to identify and evaluate, insofar as is possible, geological aspects of environmental effects resulting from geothermal development within the KGRA. The only large-scale commercial development of geothermal resources in the United States is in The Geysers-Calistoga KGRA, about $70 \mathrm{mi}(110 \mathrm{~km})$ north of San Francisco. In that area, local geologic conditions have had a significant influence on the environmental effects of geothermal development (e.g., Bacon et al., 1976). Although the specific geologic conditions that pose potential environmental problems during geothermal development differ for the Mono-Long Valley and Geysers-Calistoga areas, the local geology is (or will be) a major environmental factor affecting development in both areas.

To facilitate data collection for this study, a geology discussion group was convened as part of a workshop held at Mamnoth Lakes on August 10-11, 1978. Participants in the group, which included representatives of government agencies, academic institutions, energy companies, and public-interest organizations, are listed in Appendix A of this chapter. The discussion group brought together a broad range of expertise in geothermal development in general and the Mono-Long Valley KGRA in particular. During the workshop, the group discussed the state of geologic knowledge about the KGRA and defined the main environmental issues that need to be considered during exploration and development of geothermal resources in the region.

In order to identify and address the key environmental issues related to geology of the Mono-Long Valley region, it is first necessary to examine the presently available data. Thus the sections of this chapter are organized in the following sequence of topics:

(1). Short summary of geographical and cultural factors pertinent to geothermal development.

(2). Sumary of geologic and hydrologic information currently available for the Mono-Long Valley KGRA.

(3). Identification of major environmental issues related to geology and hydrology.

(4). Identification of gaps in data.

(5). Discussion of possible projects to acquire additional data needed for assessing environmental issues.

Because the report necessarily contains much detailed geologic terminology, a glossary of geologic terms is included as Appendix B of this chapter. A table of geologic time periods and their tentative absolute ages is included for reference purposes (Table 1). A supplemental list of references that are of regional interest but which were not cited in the text comprises Appendix c. 
TABLE 1

\section{GEOLOGICAL TIME SCALE}

Era

Cenozoic

Mesozoic $\left\{\begin{array}{l}\text { Cretaceous } \\ \text { Jurassic } \\ \text { Triassic }\end{array}\right.$

$\left(\begin{array}{l}\text { Permian } \\ \text { Pennsylvania }\end{array}\right.$

Mississippian

Paleozoic
Epoch

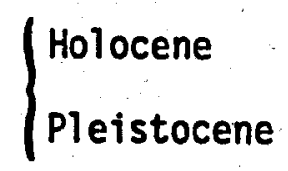

Tentative Absolute age ${ }^{a}$

$11,000 \mathrm{yr}$ 2 m.y. 12 37 53 70 135 190 230 280 350 400 430 500 600

Precambrian 600-3600 m.y. Origin of earth - - - Lost interval - - -

$a_{m \cdot y}=$ million years

Source: Sharp (1972) 
Physiography and Culture

The Mono-Long Valley KGRA encompasses $719 \mathrm{sq} \mathrm{mi} \mathrm{(1863} \mathrm{sq} \mathrm{km)} \mathrm{of} \mathrm{California}$ east of the Sierra Nevada (Fig. 1). Of this area, $709 \mathrm{sq} \mathrm{mi} \mathrm{(1838} \mathrm{sq} \mathrm{km),}$ including all areas of potential geothermal interest, are in Mono County, and $10 \mathrm{sq} \mathrm{mi} \mathrm{(26} \mathrm{sq} \mathrm{km}$ ) are in Madera County. Within the KGRA are the communities of Mammoth Lakes, June Lake, and Lee Vining.

Physiographically, the KGRA can be divided into two principal lowland areas separated by the Glass Mountain Ridge-Bald Mountain highlands. The southernmost lowland area is the Long Valley caldera, an elliptical volcano-tectonic depression measuring $18 \mathrm{mi}(29 \mathrm{~km})$ from east to west and $10 \mathrm{mi}(16 \mathrm{~km})$ from north to south. North of the highland area is Mono Basin, an irregularly shaped depression that consists of two sub-basins. Mono Valley, which contains Mono Lake, comprises the northern sub-basin, and Pumice Valley constitutes the southern sub-basin. Mono Lake, an alkaline lake which has no outlet, is $13 \mathrm{mi}(21 \mathrm{~km})$ from east to west and $9 \mathrm{mi}(14-1 / 2 \mathrm{~km})$ from north to south. Surface level of the lake was $6376 \mathrm{ft}(1944 \mathrm{~m})$ in 1976 (Loeffler, 1977, p. 12); lake level is dropping about $1.5 \mathrm{ft}(0.5 \mathrm{~m})$ per year, primarily owing to diversion of water for urban use by the Los Angeles Department of Water and Power (Loeffler, p. 32). Pumice Valley, a roughly circular depression about $6 \mathrm{mi}(10 \mathrm{~km})$ across with sparse sagebrush vegetation, is south-southwest of Mono Lake. East of Pumice Valley is the 10 -mile (16 $\mathrm{km}$ ) long Mono Craters chain, a group of volcanic domes and flows that rise as much as $2000 \mathrm{ft}(600 \mathrm{~m})$ above the adjacent valley floor.

Each of these physiographic subdivisions has a different potential for geothermal development. Therefore, the Quaternary geology of the major subdivisions will be discussed separately in this report, and the areas that have the greatest potential for geothermal development will be emphasized. The consensus of workshop participants was that the physiographic subdivisions could be ranked on the basis of geothermal potential, with Long Valley being by far the most promising area, based on presently available data. The ranking, in order of decreasing geothermal potential, is:

(1) Long Valley caldera

(2) Mono Craters area

(3) Remainder of KGRA

The principal landholders in the main areas of geothermal interest are government agencies: The U.S. Forest Service in the Long Valley caldera and the Mono Craters area, the LADWP (LOS Angeles Department of Water and Power) in Long Valley and Pumice Valley, and the BLM (Bureau of Land Management) in Mono Valley. About $95 \%$ of all land in the KGRA is owned by agencies of local, state or federal governments (U.S. Forest Service, 1972). These lands are used primarily for recreation, with logging and mining being of secondary economic importance. Pumice is quarried in the Mono Craters area, and kaolinite clay is mined in the Long Valley caldera. Also of primary economic importance, the area is part of the Owens Valley watershed which supplies water for domestic, agricultural, and fishery uses. The streams of the KGRA provide water supplies for the local comunities and the Hot Creek fish hatcheries, as well as furnishing $40 \%$ of the Los Angeles municipal water supply. The LADWP built the Lake Crowley reservoir in 1941 to store Uwens River and Mono Basin water for use by the City of Los Angeles. Water from 


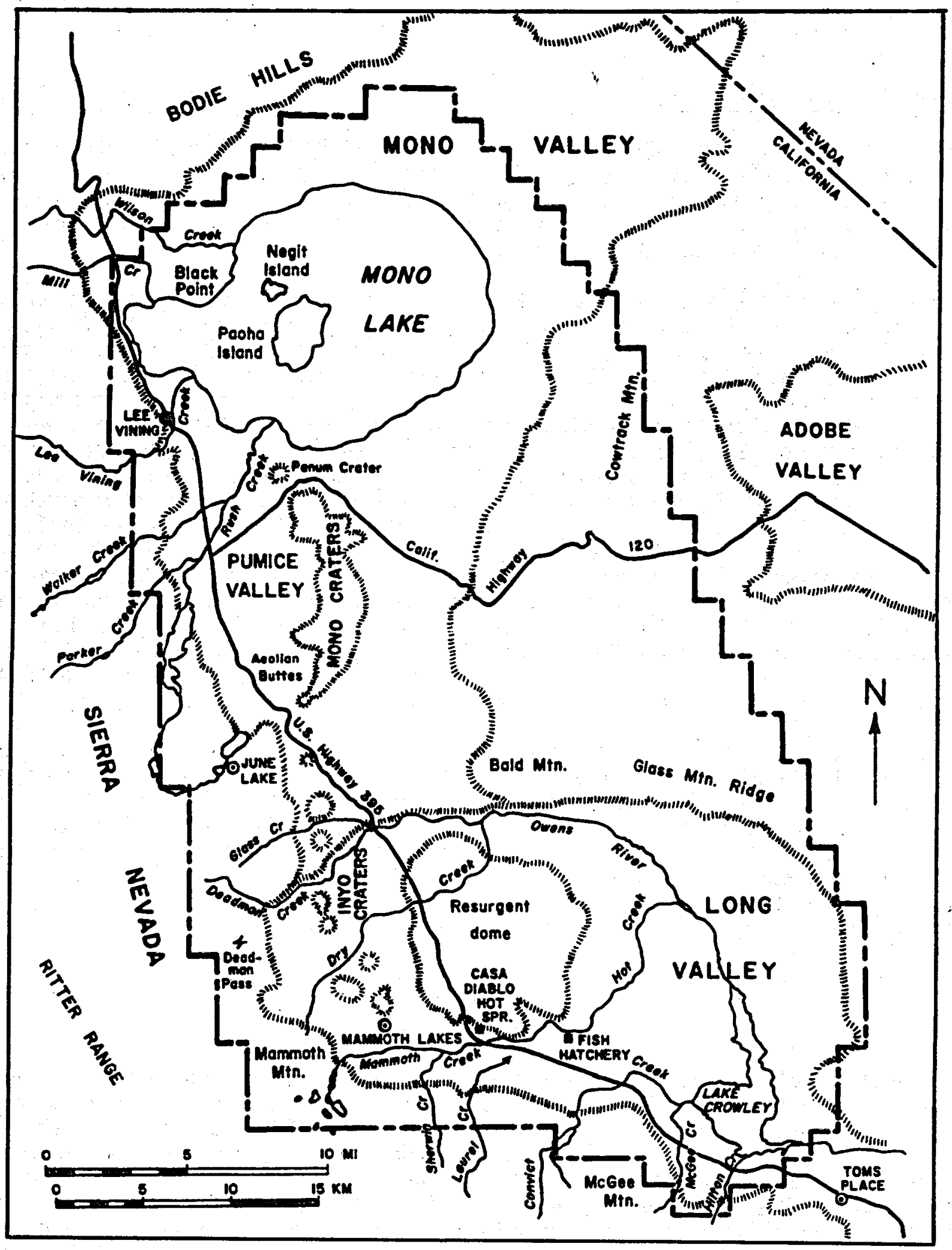

Figure 1. Index map of Mono-Long Valley region, showing boundary of KGRA. 
Mono Basin flows through the LADWP tunnel beneath the Mono Craters to the upper Owens River and thence to Lake Crowley. Hydroelectric power plants along the LADWP aqueduct system within and south of the Mono-Long Valley region generate electricity for Los Angeles.

\section{GEOLOGY}

\section{Pre-Quaternary Geology}

Much of the pre-Cenozoic geology of east-central California has been mapped by the U.S. Geological Survey, and the work is still in progress. These studies have resulted in geologic maps and reports on the Mono-Long Valley region by Rinehart and Ross (1957; 1964), Bateman (1965), Huber and Rinehart (1965), Kistler (1966a; 1966b), and Krauskopf and Bateman (1977). Additional mapping by Chesterman and Gray (1975) for the California Division of Mines and Geology has delineated the surficial and bedrock geology northwest of Mono Lake.

Most geologic age dates cited in this chapter have been determined by radiometric methods. Ages greater than 40,000 years were found by the potassiumargon (K-Ar) method. For younger rhyolitic lava flows, the obsidian hydration-rind technique was applied. Ages of tephra layers were determined by radiocarbon dating of organic material associated with the layers. Geologic age determinations cited in this report come from many sources, and primary references are given for all dates cited. The abbreviation "m.y." is used for "million years" in referring to geologic age dates.

The oldest rocks of the Mono-Long Valley region are the Paleozoic metasediments and Mesozoic metavolcanics of the eastern Sierra Nevada. These metamorphic rocks form a series of pendants in the Sierra Nevada batholith: the Mount Morrison pendant south of the Long Valley caldera, the Ritter Range pendant west of the caldera, the small Gull Lake pendant west of June Lake, and the Log Cabin Mine pendant west of Pumice Valley and Mono Lake. The Mono-Long Valley KGRA includes parts of all four pendants. Fiske and Tobisch (1978, p. 219) suggest that the thick sequence of volcanic rocks in the Ritter Range pendant was erupted during formation of a caldera in Cretaceous time. In addition to the pendants, another small mass of Paleozoic sandstone occurs along the northern edge of the Long Valley caldera (Rinehart and Ross, 1964, pl. 1) south of Ba'ld Mountain (Fig. 1 ).

Granitic rocks of the Sierra Nevada batholith are exposed along much of the western margin of the KGRA (Fig. 2). These rocks, part of the many Mesozoic plutons that comprise the batholith, range from Triassic to Cretaceous in age (Kistler et al. 1965, p. 159; Evernden and Kistler, 1970, pl. 2). In the southern part of the KGRA, Mesozoic granitic rocks crop out on all sides of the Long Valley caldera (Bailey and Koeppen, 1977) and west of the Inyo Craters chain (Huber and Rinehart, 1965, Kistler, 1966a). In the Mono Basin region, granitic rocks are exposed west of Mono Lake (Kistler, 1966a; Chesterman and Gray, 1975) and south and west of Pumice Valley (Putnam, 1949, pl. 1). Granitic rocks are also found along the eastern boundary of the KGRA, southeast of Mono Lake between Cowtrack Mountain and Glass Mountain (Strand, 1967). 


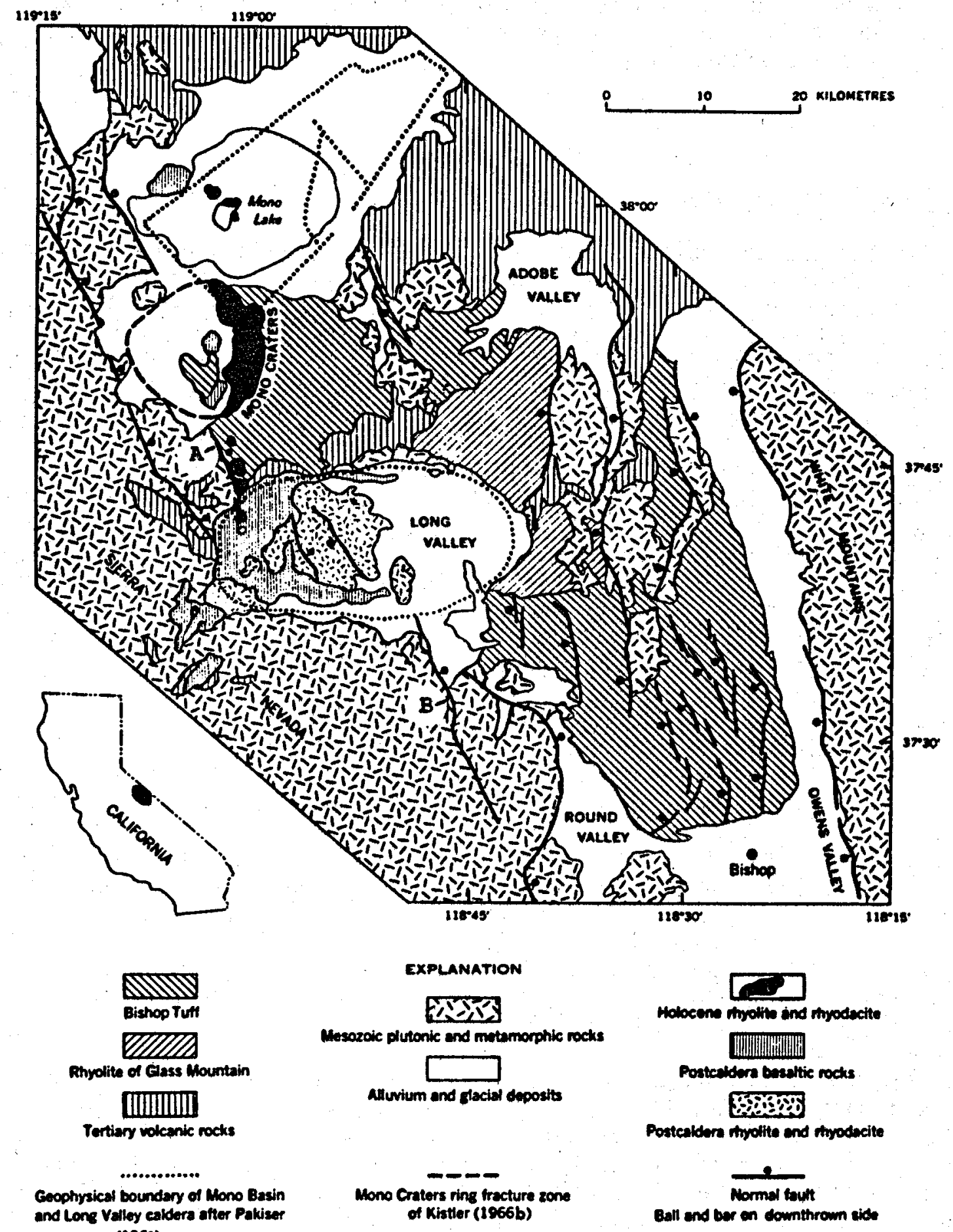

Figure 2. Generalized geologic map of the Long Valley-Mono Basin region. (From Bailey et al., 1976). Hartley Springs fault is denoted by "A", Hilton Creek fault by "B". 
Mesozoic granitic rocks and the metamorphic pendants associated with them form the basement rocks of the Mono-Long Valley region. Granitic and metamorphic rocks have been found beneath Cenozoic volcanic and sedimentary deposits in deep wells at Mono Lake (Axtell, 1972) and in the LADWP Mono Craters tunnel (Gresswell, 1940, p. 200-202). The nature of the basement rocks is also indicated by metamorphic and granitic inclusions in Cenozolc volcanic rocks throughout the region.

Rocks of Tertiary age are sparsely distributed within Mono-Long Valley KGRA. The oldest Tertiary deposit in the area is a late Miocene welded tuff near Cowtrack Mountain, dated at 12 m.y. (Gilbert et al., 1968, p. 284). Slightly younger volcanics crop out within the KGRA north of Mono Lake, where welded tuff and basalt flows (Table 2) have been dated at 9 m.y. (Chesterman and Gray, 1975), indicating an early Pliocene age.

The most abundant Tertiary rocks in the KGRA are volcanic flows of late pliocene age, mostly extruded between 2 and 4 m.y. ago. Volcanic rocks of this time span are widespread throughout the central Sierra Nevada (Bateman and Wahrhaftig, 1966, p. 141). Remnants of basalt flows dated at 2.6 to 3.1 m.y. are preserved south of the Long Valley caldera (Dalrymple, 1963, p. 380), where they overlie pre-Cenozoic granitic and metamorphic rocks. West of the caldera, andesite and rhyodacite (quartz latite) flows (Table 2) dated at about $3 \mathrm{m.y}$. (Dalrymple, 1964, p. 4-5) overlie pre-Cenozoic metamorphic rocks of the Ritter Range pendant (Huber and Rinehart, 1965). Basalt and rhyodacite flows which are widespread along the northern margin of the caldera have been correlated with similar rocks of late Pliocene age to the west of the caldera (Bailey and Koeppen, 1977, p. 12-13). The largest of the rhyodacite masses on the north rim of the caldera comprises Bald Mountain. East and southeast of Mono Lake, basalt that Gilbert et al. (1968, p. 291) consider to be of late Pliocene age covers an extensive area in the vicinity of Cowtrack Mountain (Fig. 1), along the eastern boundary of the KGRA.

During the period of late Pliocene volcanism, the east-central Sierra Nevada region probably was glaciated, and glacial-iike deposits from this episode have been dated at 3 m.y. (Curry, 1966). These deposits, which are sandwiched between two lava flows at Deadman Pass (Fig. 1) to the west of the Lnng Valley caldera, represent the oldest radiometrically dated deposits of probable glacial origin yet recognized in northern temperate latitudes. South of the caldera, remnants of a till deposited during the McGee glaciation (Table 3) are perched atop McGee Mountain (Blackwelder, 1931, p. 902). The McGee till overlies an andesite flow dated at about $2.6 \mathrm{m.y}$. (Dalrymple, 1963, p. 380), which establishes a maximum age for the glaciation and suggests that it is somewhat younger than the presumed glaciation at Deadman Pass. From geomorphic evidence, Putnam (1960, p. 274; 1962, p. 205) postulated $4000 \mathrm{ft}$ $(1200 \mathrm{~m})$ of vertical movement along Sierran range-front faults at McGee Mountain since the McGee glaciation. 


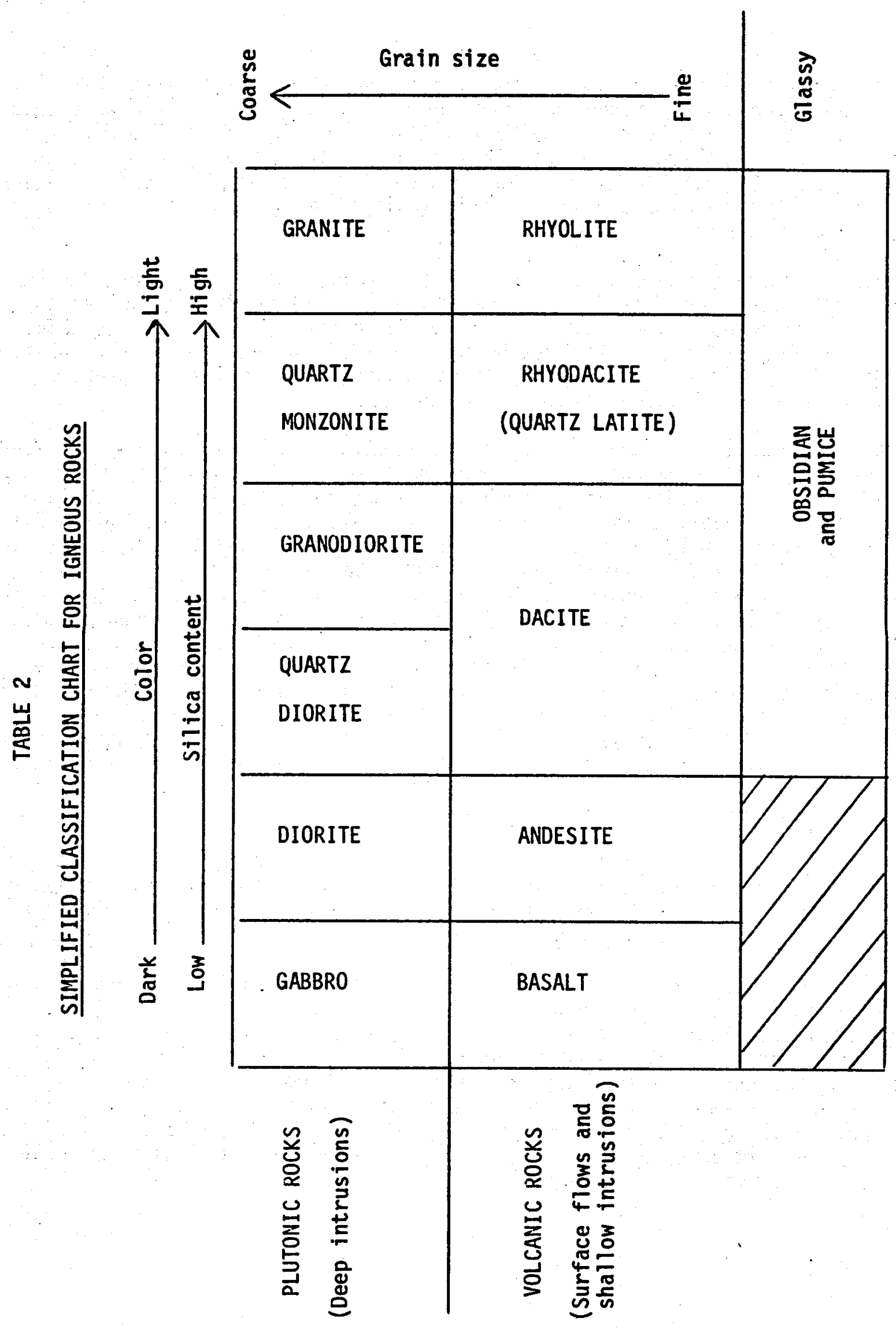


Quaternary Geology of Long Valley Caldera.

Most of the geologic units in Mono-Long Valley KGRA are volcanic units of Quaternary age. The oldest Pleistocene volcanics are the rhyolite (Table 2) flows and tuffs that comprise Glass Mountain (Fig. 2), on the northeast rim of the caldera. Bailey et al. (1976, p. 729) report that the Glass Mountain rhyolites have a total thickness of over $3300 \mathrm{ft}(1000 \mathrm{~m})$. The most widespread volcanic unit in the region between Mono Lake and Owens Valley is the Bishop Tuff, which covers an area of $450 \mathrm{sq} \mathrm{mi}(1150 \mathrm{sq} \mathrm{km})$ and has an average thickness of about $500 \mathrm{ft}(150 \mathrm{~m})$ (Gilbert, 1938, p. 1833). Eruption of the Bishop Tuff about 0.7 m.y. ago (Dalrymple and others, 1965, p. 668) partially emptied the Long Valley magma chamber and caused the roof of the chamber to collapse, thus forming the Long Valley caldera (Bailey et al., 1976, p. 731). In the southeastern corner of the KGRA, the Bishop Tuff crops out south and east of Lake Crowley (Rinehart and Ross, 1957). Bishop Tuff is also exposed on three sides of the Mono Craters chain: in the Aeolian Buttes to the west, around the Inyo Craters to the south (Kistler, 1966a), and between Bald Mountain and Mono Lake to the east (Gilbert, 1938, p. 1834). The top of the Bishop Tuff has also been found in drill holes at depths of about $550 \mathrm{ft}$ (165 $m$ ) along the south shore of Mono Lake (Axtel1, 1972) and $2285 \mathrm{ft}(697 \mathrm{~m})$ in the east-central Long Valley caldera (Smith and Rex, 1977, p. 536).

Within the caldera, flows and domes of stony rhyolite, pumiceous rhyolite, and obsidian form a broad, uplifted region about $7 \mathrm{mi}$ (11 $\mathrm{km}$ ) across in the west-central part of the depression. The uplifted region constitutes a central "resurgent dome" with 500 to $1000 \mathrm{ft}(150$ to $300 \mathrm{~m})$ of relief, surrounded by a "moat" partly filled with younger volcanic and sedimentary deposits (Fig. 3). Bailey (1974) has identified 12 source vents for the rhyolite and rhyolitic tuff breccla of the resurgent dome of the caldera. Three younger masses of rhyolite (Fig. 5) are on the margin of the resurgent dome, in the north, southeast, and west moats of the caldera (Bailey, 1974).

Basalt and andesite flows are widespread in the west, north, and south moats of the caldera. In the south moat (and probabiy the north moat, too), lava appears to have flowed eastward from source vents in the west. Individual lava flows typically are about $30 \mathrm{ft}(10 \mathrm{~m})$ thick; in the south moat, they are interbedded with pre-Wisconsin (Table 3) glacial deposits (Curry, 1971, p. 41). Related basalt flows exposed south of Mammoth Mountain extend westward into the San Joaquin River drainage basin (Huber and Rinehart, 1965). In the south moat of the caldera, the lava flows are mantled by till, glacial outwash, and alluvial deposits derived from the Sierran range front to the south. Most of the glacial deposits resulted from the Wisconsin glaciations (Table 3 ) that produced extensive deposits throughout the Sierra Nevada.

The youngest volcanic rocks of the Long Valley caldera are the rhyolite domes of the Inyo Craters chain, in the west moat north of Mamoth Mountain. The Inyo Craters chain includes three domes within the caldera and two more domes to the north of the caldera boundary. Wood (1977a, p. 95) reports that some of the domes are less than 800 years old. At the south end of the chain are three craters, the southernmost of which has been dated at $550 \pm 60$ years (Wood, 1977a, P. 92).

The eastern part of the caldera has extensive lake deposits that accumulated in Long Valley Lake (Mayo, 1934), the Pleistocene lake that filled the basin 


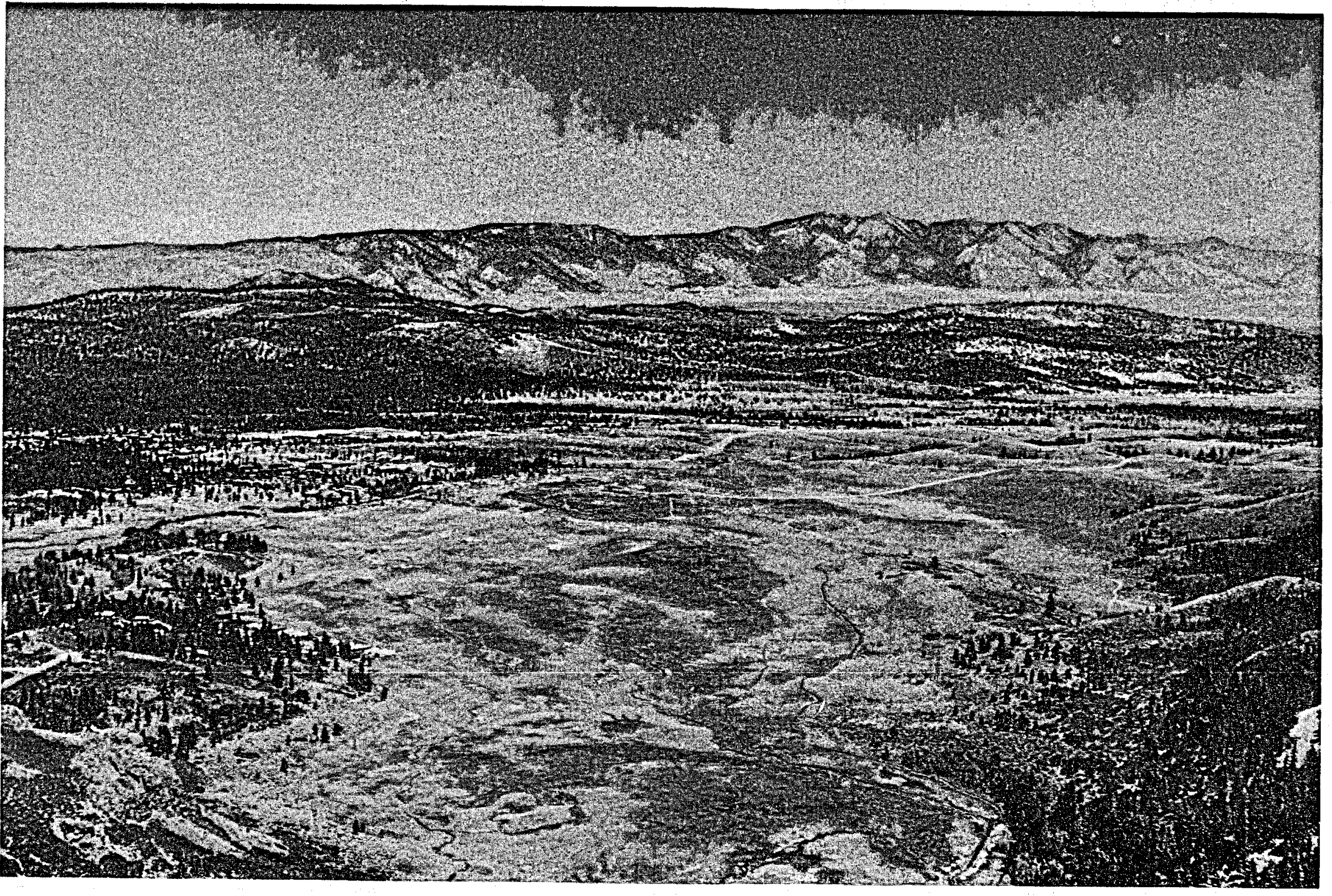


formed by the collapse of the caldera. Lakebeds consist predominantly of tuffaceous sandstone, conglomerate, breccia, and chert, mostly derived from rhyolite of the resurgent dome; the dominant lithology is silica-cemented conglomeratic sandstone. Rinehart and Ross (1964, pl. 1) mapped 16 sq mi (42 sq $\mathrm{km}$ ) of exposed lake deposits in the Long Valley caldera, and it is likely that a comparable additional area of lakebeds is concealed by younger alluvial deposits.

Hill (1976, P. 749) and Kane et al. (1976, p. 756) used seismic and gravity data respectively to estimate the total thickness of Long Valley caldera fill. They calculated a total thickness for Quaternary sedimentary and volcanic fill of about $6500 \mathrm{ft}(2 \mathrm{~km})$ in the southwestern part of the caldera and about $10,000 \mathrm{ft}(3 \mathrm{~km})$ in the northeastern part. As of 1978, subsurface stratigraphic information for the caldera is available from only one deep exploratory hole. The wildcat geothermal well was drilled jointly by the City of Burbank and Republic Geothermal, Inc, in 1976 to a depth of $6920 \mathrm{ft}$ (2110 $m)$. The well encountered sedimentary fill in the upper $1100 \mathrm{ft}(335 \mathrm{~m})$, early post-caldera rhyolite tuff in the depth interval from 1100 to $2285 \mathrm{ft}$ (335 to $697 \mathrm{~m}$ ), and Bishop Tuff in the remaining $4635 \mathrm{ft}(1413 \mathrm{~m}$ ) of the hole (Smith and Rex, 1977 , p. 536). Drilling was halted before the well penetrated the granitic-metamorphic basement rocks presumed to lie at depth.

Using seismic refraction profile data, Hill (1976, p. 751) identified a low-velocity region beneath the caldera at a depth of 4.3 to $5 \mathrm{mi}$ ( 7 to $8 \mathrm{~km}$ ). He suggested that this velocity contrast represents the top of a residual magma chamber. Steeples and Iyer (1976, P. 859) used teleseismic data (P-wave arrivals from distant earthquakes) to recognize a low-velocity zone beneath the caldera that they attributed to anomalously high temperatures, due to either magma or hot rock. They ( $p .858-859$ ) inferred that any magma chamber that exists is at a depth of at least $4.3 \mathrm{mi}(7 \mathrm{~km})$ and probably does not extend below a depth of about $15 \mathrm{mi}(25 \mathrm{~km})$. Teleseismic arrival data indicate that the low-velocity region is confined to the western part of the caldera (Steeples and Iyer, p. 859). Roy A. Bailey (personal comunication, 1978) suggests that the possible magma chamber may approximately underlie the resurgent dome of the caldera.

Late Quaternary Geology of Northern Part of KGRA

In the part of the Mono-Long Valley KGRA north of the Long Valley caldera, geologic units that postdate the Bishop Tuff can be grouped in four categories: volcanic, glacial, lacustrine, and alluvial. Volcanic rocks of the area are predominantly rhyolitic but also include basalt flows between June

Figure 3 (facing page). View east-northeast across the Long Valley caldera toward Glass Mountain Ridge, which forms the far rim of the caldera, on the skyline. In the middle distance are the low hills and ridges of rhyolite that comprise the resurgent dome of the caldera. A series of low, subdued ridges formed by glacial moraines covers the caldera floor on the near side of the resurgent dome. These glacial deposits, mostly of Wisconsin age, overlap Pleistocene basalt and andesite flows. The town of Mammoth Lakes is in the middle distance on the left. 
TABLE 3

CORRELATION OF GLACIAL SEQUENICES OF THE EASTERN SIERRA NEVADA, CALIFORNIA

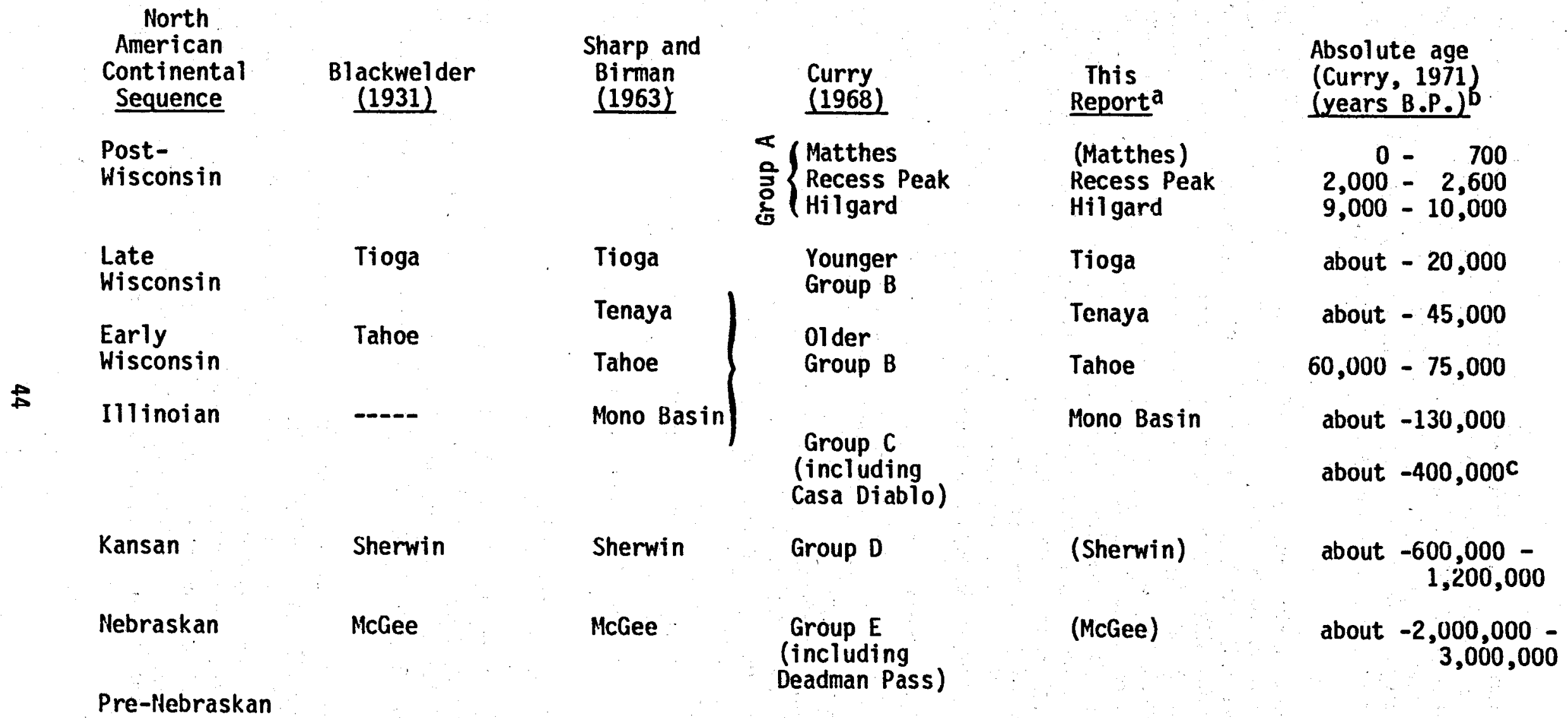

aGlacial episodes not represented by deposits in the Marmoth Creek area are shown in parentheses.

bB.P. means "before present," which is taken to be A.D. 1950.

CNew potassium-argon dates suggest that the Casa Diablo till is of Mono Basin age and does not represent a separate glacial episode (Bailey, et al. 1976, p. 735). 

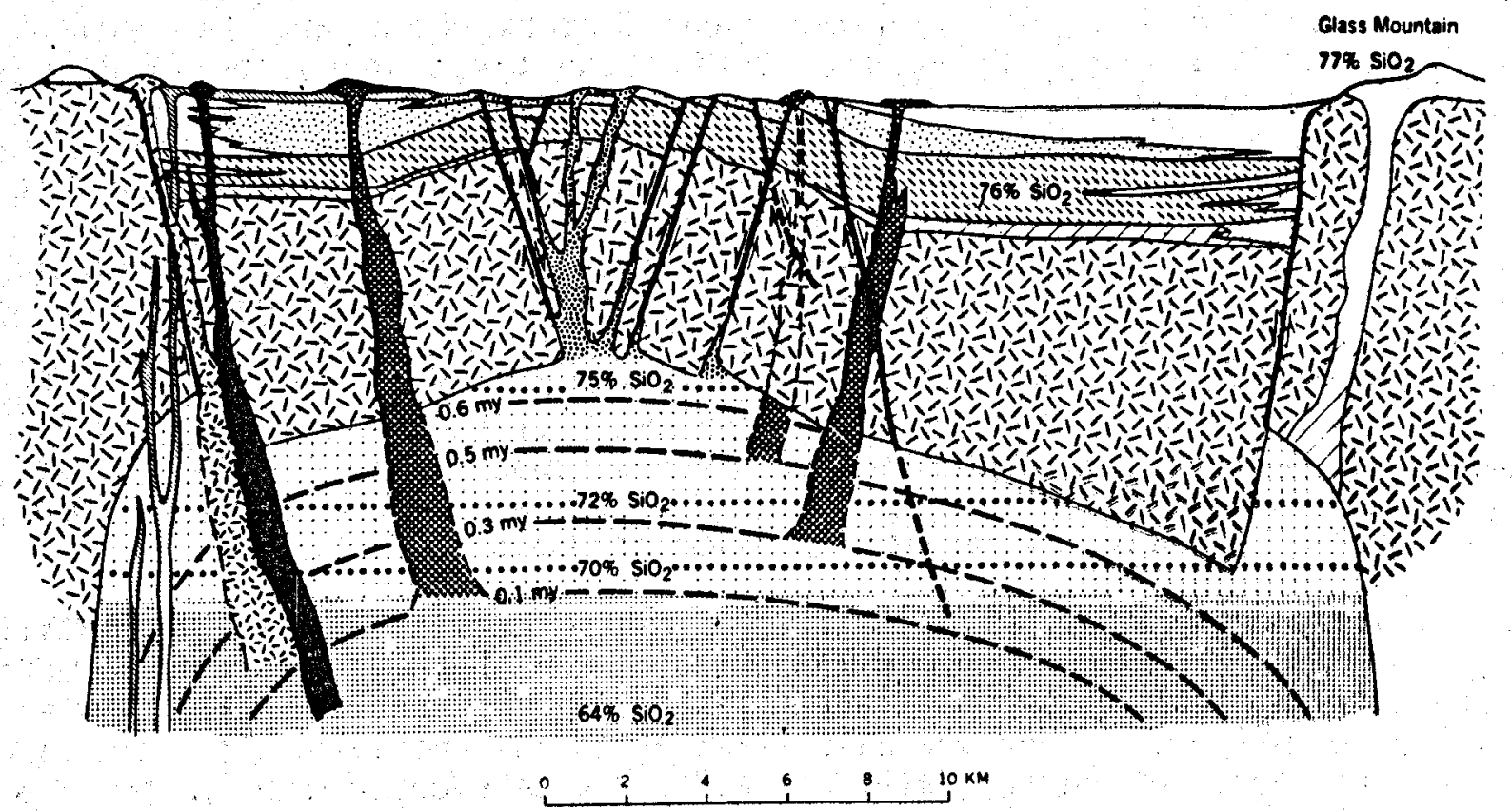

Figure 4. Schematic east-west cross section through Long Valley caldera and its subjacent magma chamber. Heavily dotted part of chamber is rhyodacite magma; lightly dotted part is rhyolite magma. Horizontal dotted lines show silica gradient in vertically zoned chamber. Curved dashed 1 ines show depth to residual magma at specified times. The vertical scale is unspecified because of uncertainties in subsurface data. Pre-Cenozolc metamorphic rocks are included with granitics in cross section. (From Bailey et al., 1976).

EXPLANATION

Alluvium, glacial deposits, and caldera fill

- Holocene rhyolite-rhyodacite

Late basaltic rocks

[Sim inyodacites

Moat rhyolites

Early myolites $\left\{\begin{array}{l}\text { tuffs: fine dotted } \\ \text { flows: coarse dotted }\end{array}\right.$

Eitinis Bishop Tuff

Rhyolite of Glass Mtn $\left\{\begin{array}{l}\text { dome flows: fine lined } \\ \text { tutfs: coarse lined }\end{array}\right.$

1III Tertiary volcanic rocks

[1-1 Jurassic-Cretaceous granitic rocks 
Lake and the Mono Craters (Kistler, 1966a) and andesite flows in the vicinity of the Inyo Craters chain. At Black Point, on the northwest shore of Mono Lake, is a basalt cinder cone dated by $K$. R. Lajoie at about 13,000 years (Wood, 1977a, p. 90). The prominent Mono Craters chain and its southward extension, the Inyo Craters chain, consist mostly of domes and flows of rhyolite and rhyodacite (Kistler, 1966a; Huber and Rinehart, 1967, p. D17; Wood, $1977 a$, p. 89). The dacitic to rhyolitic lava flows of Mono Lake's two islands form the northern end of the Mono Craters chain. From its northern end at Mono Lake, the Mono-Inyo chain of rhyolitic extrusions extends southward for $23 \mathrm{mi}(37 \mathrm{~km})$ as a series of unforested or sparsely wooded volcanic domes and flows to the Inyo Craters within the Long Valley caldera. Much of Mono-Long Valley KGRA, particularly around Mono Lake and Mammoth Mountain, is blanketed with pumice ash and lapilli produced in the most recent of the dozens of pumice eruptions that have occurred in the region. The pumice layers, the youngest of which has been dated at about 720 years (Wood, 1977a, p. 92), are derived from the Inyo and Mono Craters and Mamoth Mountain (Wood, 1977a, p. 93-94; Robert P. Koeppen, personal comunication, 1976).

Late Quaternary glacial deposits of the region consist primarily of till deposited during the Wisconsin glaciations. These deposits, mostly products of the Tahoe and Tioga glacial episodes (Table 3), occur on the western boundary of the KGRA, along the east flank of the Sierra Nevada. In the June Lake region south of Pumice Valley, glacial deposits cover most of the area between the Sierran range front and the southern Mono Craters (Kistler, 1966a) and underlie at least part of the Mono Craters domes and flows (Gresswell, 1940).

Late Pleistocene lakebeds are exposed on Paoha Island in Mono Lake and on all sides of the lake, including a large area of Mono Valley northeast of the lake (Koenig, 1963; Strand, 1967). They were deposited in a large lake, four times the size of modern Mono Lake, that filled Mono Basin (Russell, 1889, p. 299) and may have overflowed into Adobe Valley to the east (Putnam, 1949, P. 1296). The lakebeds consist of tuffaceous silt, sand, and gravel (Lee, 1969, p. 20; Chesterman and Gray, 1975), with calcareous tufa locally along the lake margin. The tufa, although limited in areal extent, is quite prominent along the lakeshore and is considered to be a major scenic attraction of the area.

Holocene alluvial deposits cover Pumice Valley and part of the region east of the Inyo and Mono Craters chain. The deposits are mantled by a veneer of Holocene pumice ash and lapilli derived from the Inyo and Mono Craters eruptions.

The geologic structure of Mono Basin has been a subject of controversy in recent years. Geophysical data (gravity and seismic) were interpreted by Pakiser and others " $(1960$, p. 445) to indicate that the basin is a deep structural depression bounded by vertical faults. They calculated a total thickness of $18,000 \pm 5000 \mathrm{ft}(5.5 \pm 1.5 \mathrm{~km})$ of volcanic and sedimentary fill overlying the pre-Cenozoic basement rocks of the basin. Using. additional seismic data, Pakiser (1968, p. 1835) later reached essentially the same conclusion as in the earlier study. Christensen and others (1969, p. 5224), however, concluded from surface geologic evidence that Mono Basin is a broad, 
shallow downwarp rather than a deep, fault-bounded depression. They ( $p, 5234$ ) calculated volumes for sedimentary debris and volcanic material deposited in Mono Basin and estimated the thickness of Cenozoic fill to be between 3300 and $5000 \mathrm{ft}$ ( 1 and $1.5 \mathrm{~km})$. In an attempt to resolve the discrepancy between the two interpretations, Pakiser (1976) used additional seismic data to reinterpret the structure of the basin. He ( $p .3618)$ concluded that Cenozoic fill in the basin is about 6500 to $8200 \mathrm{ft}(2$ to $2.5 \mathrm{~km})$ thick and that Mono Basin was formed by a combination of faulting and downwarping. The two conflicting interpretations are not fully resolved, however, and there is no general consensus regarding the subsurface structure of Mono Basin. Recent geothermal exploratory drilling (Axtel1, 1972) encountered granitic basement rocks at depths close to those predicted by Christensen and others (1969), but it is possible that the wells were sited outside of the postulated boundary faults of the structural basin.

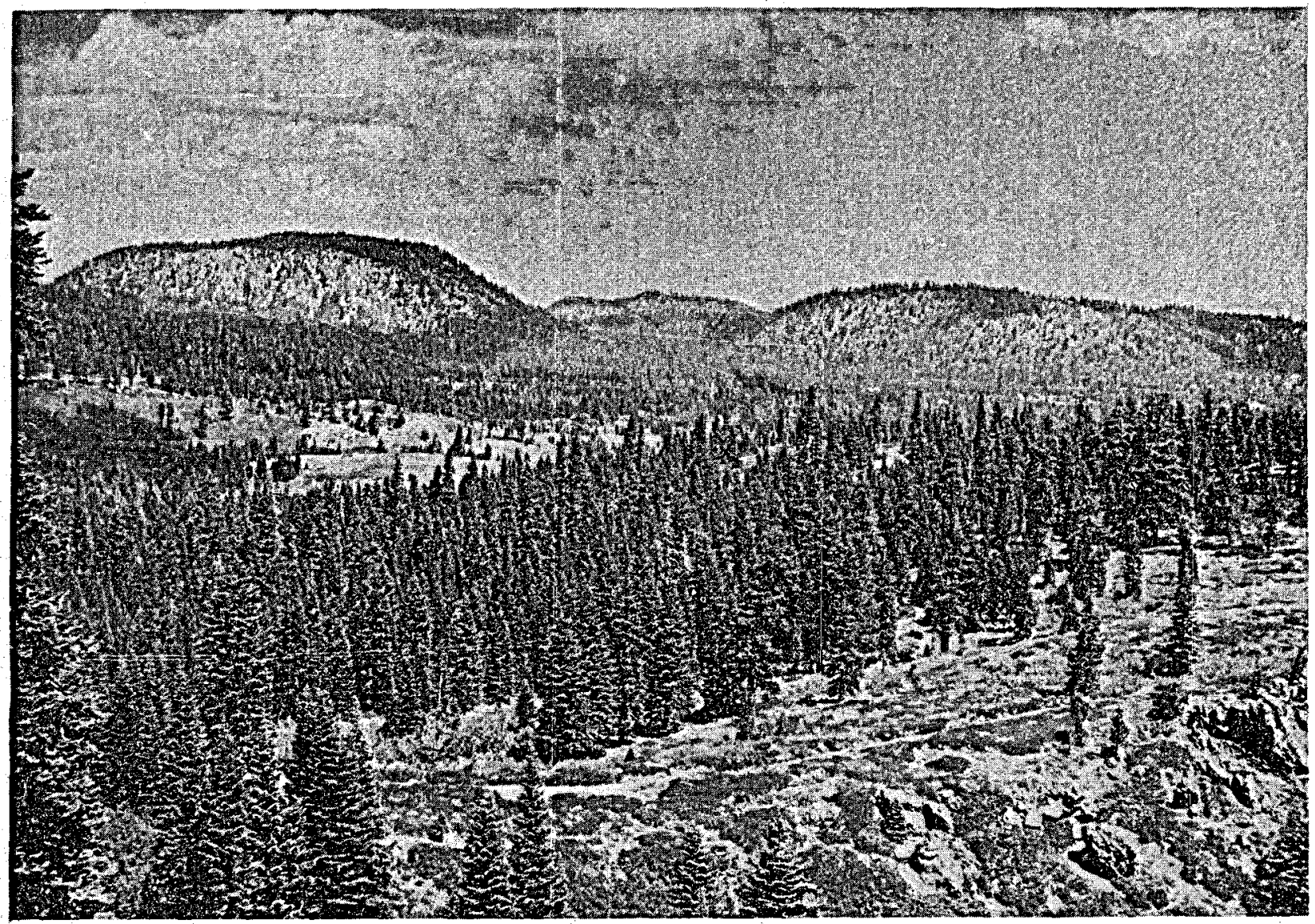

Figure 5. View north toward volcanic domes of western Long Valley caldera. Structures include a rhyodacite dome (left) which is satellite to Mammoth Mountain to the west (not shown in photo), a dome of younger rhyolite (middle) in the distance, and twin domes of younger rhyolite (right) north of the Mammoth Lakes townsite. The three domes of younger rhyolite have been $K-A r$ dated at about $0.1 \mathrm{m.y.}$; the rhyodacite dome has been dated at about $0.14 \mathrm{~m} \cdot \mathrm{y}$. (Bailey et al.., 1976, p. 729). In the foreground is a till-mantled rhyodacite flow, part of the Mammoth Mountain complex of lava flows and domes. 
HYDROLOGY

Surface Hydrology

The Mono-Long Valley KGRA includes two principal drainage basins. Long Valley basin in the south contains the headwaters of the Owens River system. Mono Basin in the north is a closed basin with internal drainage under natural conditions, but part of its drainage is diverted into the Los Angeles aqueduct system. A small segment of the KGRA between Cowtrack and Glass Mountains drains eastward into Adobe Valley (Fig. 1). Data on springs and streamflow for Long Valley are included in reports by the California Department of Water Resources (1973). Lewis (1974), and Lipshie (1974). Further information is contained in unpublished reports of the California Department of Fish and Game and the LADWP. For the Mono Basin region, the main references for hydrologic data are Loeffler (1977) and Lee (1969).

The northern and eastern sectors of the Long Valley caldera are drained by the Owens River, which flows into Lake Crowley in the southeastern part of the caldera. The lake, which was created in 1941. when the LADWP built Long Valley Dam, issues Into the Owens Valley through Owens River Gorge. In the northwest quadrant of the caldera, Deadman, Glass, and Dry Creeks form the headwaters of the Owens River. The south moat of the caldera is drained by Mammoth Creek, which rises in the Sierra Nevada south of the KGRA and flows eastward from the Mammoth Lakes to the Owens River. Mammoth Creek is known as Hot Creek east of U.S. Highway 395 because of numerous hot springs along the lower course of the creek. Other streams along the south rim of the caldera flow northward from the Sierra Nevada into Mammoth Creek or Lake Crowley; principal among these are (from west to east) Sherwin, Laurel, Convict, McGee, and Hilton Creeks (Fig. 1).

Most of the cold springs in the Long Valley basin are concentrated along the physiographic rim of the caldera. A group of tepid springs, formed by mixing of cold and hot waters, provides the water supply for fish hatcheries along Hot Creek. The main aquifer for the tepid springs is a fractured basalt flow (Lipshie, 1974, p. 103). Hot springs occur along the southern and southeastern margins of the resurgent dome and in the region between Hot Creek and Lake Crowley (Sorey and Lewis, 1976, p. 786). Several small fumaroles also are reported on the flanks of Mamnoth Mountain (Huber and Rinehart, 1967, p. D19; Curry, 1971, p. 4).

The Pumice Valley-June Lake segment of Mono Basin is drained by Rush Creek, which flows northward into Mono Lake. The remainder of Mono Basin is drained by several perennial and numerous intermittent streams. The major streams are (from south to north) Parker, Walker, Lee Vining, Mill, and Wilson Creeks (Fig. 1), all of which have their headwaters in the Sierra Nevada and flow westerly toward Mono Lake. The first two streams are tributaries of Kush Creek; the others flow directly into the lake. Most of the water of Lee Vining, Walker, Parker, and Rush Creeks is diverted by the LADWP into the Mono Craters tunnel, becoming part of the Los Angeles municipal water supply stored in Lake Crowley. 
Russell (1889, pl. 17) in his classic study of Mono Basin located numerous cold springs around Mono Lake, particularly along the south shore and between the north shore and the Bodie Hills. Lee (1969) used infrared remote sensing to identify cool springs along the lakeshore and warm springs both along the shore and in the lake. Tufa towers, which are widespread along the south, west, and north shores, also provide information about occurrences of springs. Because tufa is deposited at sites of springs, the distribution of tufa towers indicates former spring activity in and around Mono Lake (Loeffler, 1977, p. 21). Hot springs occur along the northwest and northeast shores of the lake and on Paoha Island in the lake (Russe11, 1889, p. 288; Wood, 1977b, p. 41).

\section{Groundwater Hydrology}

The hydrologic regime of the Mono-Long Valley region is not as well known as is its geology. In the Long Valley caldera, hydrologic investigations were initiated by the California Department of Water Resources (1967; 1973) and followed by more intensive studies by the U.S. Geological Survey (Lewis, 1974; Lachenbruch et al., 1976a, 1976b; Mariner and Willey, 1976; Sorey and Lewis, 1976; Sorey et al., 1978). In Mono Basin, though, very little hydrologic work has been undertaken. The principal hydrologic study of the basin is that of Lee (1969), who emphasized the use of infrared remote sensing to locate and evaluate shoreline springs around Mono Lake. Lee also discussed the shallow aquifers, groundwater recharge, and water quality of Mono Basin. No hydrologic studies have been carried out in the remainder of Mono-Long Valley KGRA, insofar as groundwater is concerned. Except for the Long Valley caldera, the hydrologic data base is inadequate for characterizing the hydrologic regime. A significant amount of data on surface water quantity and quality in the region exists in the files of the LADWP.

Long Valley caldera fill consists of interbedded volcanic rocks (lava flows and tuffs) and sedimentary deposits (lakebeds, stream deposits, and glacial outwash). Fraotured lava flows tend to be more permeable than poorly sorted sediments, such as glacial material (California Dept. Water Resources, 1973, p. 31-36; Lipshie, 1974, p. 103-104). Shallow temperature measurements indicate that cool groundwater recharge occurs along the periphery of the caldera, particularly along the western and, to a lesser extent, northeastern margins (Lachenbruch et al., 1976b, p. 767). Therefore, the overall circulation of shallow groundwater is from west to east.

The area of hot springs is mostly south and east of the resurgent dome, between Casa Diablo Hot Springs and Lake Crowley, with about 80 percent of the hot-water discharge occurring in Hot Creek Gorge (Sorey and Lewis, 1976, p. 789). The groundwater that feeds the hot springs flows through the western half of the caldera where it is heated (Lachenbruch et al.., 1976b, p. 767). An order-of-magnitude estimate for the time required for groundwater to circulate through the system from recharge in the west to discharge at the hot springs along Hot Creek is $10^{2}$ to $10^{3}$ years (Frank H. Olmsted, personal comunication, 1978). Most hot springs and zones of 
hydrothermal alteration are associated with Quaternary faults, which suggests that water circulates between heat reservoirs and the surface through fractured rocks of fault zones. Unlike The Geysers area, which has a vapordominated geothermal system, the Long Valley caldera has a hot-water dominated system (White and Williams, 1975, p. 6, 12).

Between 1959 and 1962, Magma Power Company drilled ten geothermal wells at Casa Diabio. Hot Springs. Total depths of the nine completed wells range from 405 to $1063 \mathrm{ft}$ (123 to $324 \mathrm{~m}$ ) (McNitt, 1963, p. 28). These wells tap a shallow hydrothermal reservoir of unknown areal extent that appears to be associated with north-northwest-trending faulting of the resurgent dome. The shallow reservoir may be a local feature that is fed by hot water circulating along fractures from a deeper, more extensive hydrothermal reservoir.

Various chemical mixing-model geothermometers provide temperature estimates for the deep hot-water reservoir that range from about $210^{\circ} \mathrm{C}$ to $280^{\circ} \mathrm{C}$ (Sorey and others, 1978, P. A23): Waters of thermal springs are mixtures of hot water from deep sources and less saline, cooler water from one or more shallow aquifers (Mariner and Willey, 1976, p. 792). About 20 percent of the total hot-spring flow in the caldera is contributed by hot water from a deep hydrothermal system. (Sorey and Lewis, 1976, p. 785). Isotopic analyses suggest that the recharge water for the hot springs is derived from Sierra Nevada runoff water (Mariner and Willey, 1976, p. 796).

Lachenbruch et al. (1976a, p. 780) speculate that eruption of the Bishop Tuff 0.7 m.y. ago may have exhausted the magma source in the eastern part of the Long Valley caldera, leaving a residual magma chamber beneath the resurgent dome. Widespread hydrothermal alteration and siliceous sinter deposits in the eastern half of the caldera indicate that hydrothermal activity (and presumably high heat flux) formerly was more extensive than at present. Bailey et al. (1976, p. 738) date the beginning of this activity at about 0.3 m.y. A large quantity of heat is currently being removed from the caldera by water flow (Sorey and Lewis, 1976, p. 790). Lachenbruch et al. (1976b, p. 768) conclude that to account for this prolonged high heat aflow, the Long Valley hydrothermal reservoir had to be resupplied periodically with heat from deep magmatic sources, rather than being replenished by emplacement of postcaldera volcanic rocks. As possible mechanisms for the resupply of heat, they suggest circulation of fluids in gradually deepening fractures, convection in the magma chamber, or repeated replenishing of magma.

Sorey et al. (1978) have used available geological and geophysical data to model the Long Valley hydrothermal system. Their hydrologic model, as they point out, is probably oversimplified and is non-unique in terms of fitting the presently known constraints, but it serves as a starting point for further hydrologic and geothermal resources studies.

Their model assumes that the main hot-water reservoir is in welded Bishop Tuff, its permeability being due to pervasive fracturing. In the model, the Bishop Tuff is $4600 \mathrm{ft}(1.4 \mathrm{~km})$ thick and is overlain by $3300 \mathrm{ft}(1 \mathrm{~km})$ of interbedded post-caldera volcanic and sedimentary fill. They consider 
the hydrologic system to consist of two subsystems: a shallow, relatively cold groundwater system in the post-caldera fill, and a deep, relatively hot groundwater system in the welded Bishop Tuff and underlying basement rocks. The deep hydrothermal reservoir in the tuff and fractured basement rocks is taken to be in the depth interval between 3300 and $10,000 \mathrm{ft}$ ( 1 and 3 $\mathrm{km})$. Temperatures in the simulated reservoir are $200^{\circ} \mathrm{C}$ to $280^{\circ} \mathrm{C}$ underneath Hot Creek Gorge but only $80^{\circ} \mathrm{C}$ in the southeastern part of the caldera, owing to recharge of that segment of the reservoir by cold groundwater from the Glass Mountain area. Most of the recharge to the deep hydrothermal reservoir, however, is derived from the western margin of the caldera by way of the upper reaches of the Owens River drainage basin.

Geologic evidence indicates widespread hydrothermal activity in the caldera during the past $0.3 \mathrm{m.y}$. , but analysis of evaporites deposited about $150 \mathrm{mi}$ $(240 \mathrm{~km})$ downstream from the caldera in Searles Lake provides evidence only for hydrothermal activity during the last 30,000 to 40,000 years (G.I. Smith, 1976, p. 93). Therefore, Sorey et a1. (1978, p. A47-A48) considered two cases of hydrothermal history: (1) continuous hydrothermal activity persisting for the past 350,000 years, and (2) intermittent hydrothermal activity, the most recent active period beginning 35,000 years ago after nearly 300,000 years of quiescence. In order to maintain the present rate of hydrotheraml activity for 350,000 years, fluids would have to circulate to depths of 2.5 to $3 \mathrm{mi}$ ( 4 to $5 \mathrm{~km}$ ); to maintain it for 35,000 years, circulation would have to reach depths of 1 to $1.5 \mathrm{mi}(1.5$ to $2.5 \mathrm{~km}$ ) (Sorey et a1., $\mathrm{p} . \mathrm{A} 52-\mathrm{A53}$ ).

\section{GEOLOGIC HISTORY}

In the Mono-Long Valley region, the geologic record begins with Paleozoic marine sedimentation, during which a thick succession of chert, shale, siltstone, sandstone, and limestone accumulated. In the east-central Sierra Nevada near the KGRA, two sequences of Paleozoic deposits are preserved: older rocks, of Ordovician and Silurian age, probably were deposited in moderately deep water; younger rocks, of Pennsylvanian and Permian age, were deposited in shallow seas. The Paleozoic sedimentary rocks were regionally metamorphosed and deformed during Paleozoic or Mesozoic time.

Volcanic activity that continued through most of the Mesozoic era produced a thick accumulation of lava, tuff, and volcanic breccia. Mesozoic volcanism was related to emplacement at depth of granitic magma bodies that were forming the plutons of the Sierra Nevada batholith. Throughout Mesozoic time, from about $210 \mathrm{~m} . \mathrm{y}$. to about $80 \mathrm{~m} \cdot \mathrm{y}$. ago, granitic plutons were intruded into the metamorphic rocks of eastern California and western Nevada. Intrusion occurred in five major episodes at intervals of about $30 \mathrm{~m} . \mathrm{y} .$, thus forming the massive Sierra Nevada batholith, which is $370 \mathrm{mi}(600 \mathrm{~km})$ long and about $60 \mathrm{mi}$ $(100 \mathrm{~km})$ wide.

During Cenozoic time, volcanic activity was widespread in the Nevada-eastern California region. The oldest dated volcanic rocks in the region are of 01 igocene age and have dates of 28 to $33 \mathrm{m.y}$. In Mono-Long Valley KGRA, the 
oldest dated Cenozoic volcanics have an age of about $12 \mathrm{~m} \cdot \mathrm{y}_{\bullet}$, which indicates extrusion during late Miocene time. These rocks crop out southeast of Mono Lake and are related to extensive ash-flow and lava eruptions that began between 11 and $12 \mathrm{~m} . \mathrm{y}$. ago and ended about $8 \mathrm{~m} . \mathrm{y}$. ago. No volcanism of this time span has been recognized el sewhere in Mono-Long Valley KGRA. This interval was followed by a period from 8 to $4 \mathrm{~m} . \mathrm{y}$. ago during which volcanic activity was quiescent in the region, except for minor extrusions in the Bodie Hills.

The widespread volcanism of late Miocene and Pliocene time was probably related to the concurrent tectonic activity associated with crustal extension in the Basin and Range region of the western United States. Regional faulting that formed the basins and ranges east of the Sierra Nevada is thought to have begun in late Miocene time, not more than $18 \mathrm{m.y}$. ago. During late Tertiary time, the Sierra Nevada-White-Inyo Mountains region was uplifted to form a broad arch. Uplift may have started 15 to $20 \mathrm{~m} . y$. ago, but evidence for Miocene tilting is inconclusive, and uplift may not have begun until the beginning of Pliocene time, $10 \mathrm{m.y}$. ago. In either case, most of the uplift took place in the last $9 \mathrm{~m} \cdot \mathrm{y}$. and was essentially completed by the end of Pljocene time--although it is still continuing at a measurable rate.

Toward the end of the Pliocene, the eastern escarpment of the Sierra Nevada developed as the central part of the broad regional arch began to collapse. The north-trending trough thus produced includes (from north to south) the Bridgeport, Mono, and Owens Valleys. A widespread pulse of volcanism occurred between 2 and $4 \mathrm{~m} . \mathrm{y}$. ago, during which basalt, andesite, and rhyodacite (quartz latite) flows were extruded throughout the central Sierra Nevada region. The concurrence of volcanism and tectonic activity suggests that fractures associated with range-front faulting may have provided conduits for the extrusion of lava.

About 2 m.y. ago, an arcuate fracture zone developed along the northeastern. margin of the not-yet-formed Long Valley caldera. The rhyolite flows of Glass Mountain (Fig. 2), which are the oldest rocks associated with the Long Valley magma chamber, were extruded along the incipient ring-fracture system. The Glass Mountain rhyolites are believed to have been emplaced over a period of 1 m.y., from 1.9 to $0.9 \mathrm{m.y}$. ago.

The next major event in the formation of the Long Valley caldera was the catastrophic eruption of the Bishop Tuff about $0.7 \mathrm{m.y}$. ago. About $125 \mathrm{cu}$ mi $(500 \mathrm{cu} \mathrm{km})$ of ash flows and $75 \mathrm{cu} \mathrm{mi}(300 \mathrm{cu} \mathrm{km})$ of air-fall ash were emplaced over a very short time span, perhaps only a few days. Most of the ash flows spread southward to form the Volcanic Tableland north of Bishop, the remainder flowing northward into Mono Basin and Adobe Valley, and westward into the San Joaquin River basin. Airborne ash from this event was widely dispersed across the western United States, being carried as far east as Nebraska. Eruption of the Bishop Tuff partially emptied the magma chamber, and the roof of the chamber collapsed, forming the elliptical depression of the caldera. Caldera subsidence totals $2 \mathrm{mi}(3 \mathrm{~km})$, of which one third is reflected in present topographic relief and the other two thirds are represented by post-caldera basin fill (Fig. 4). 


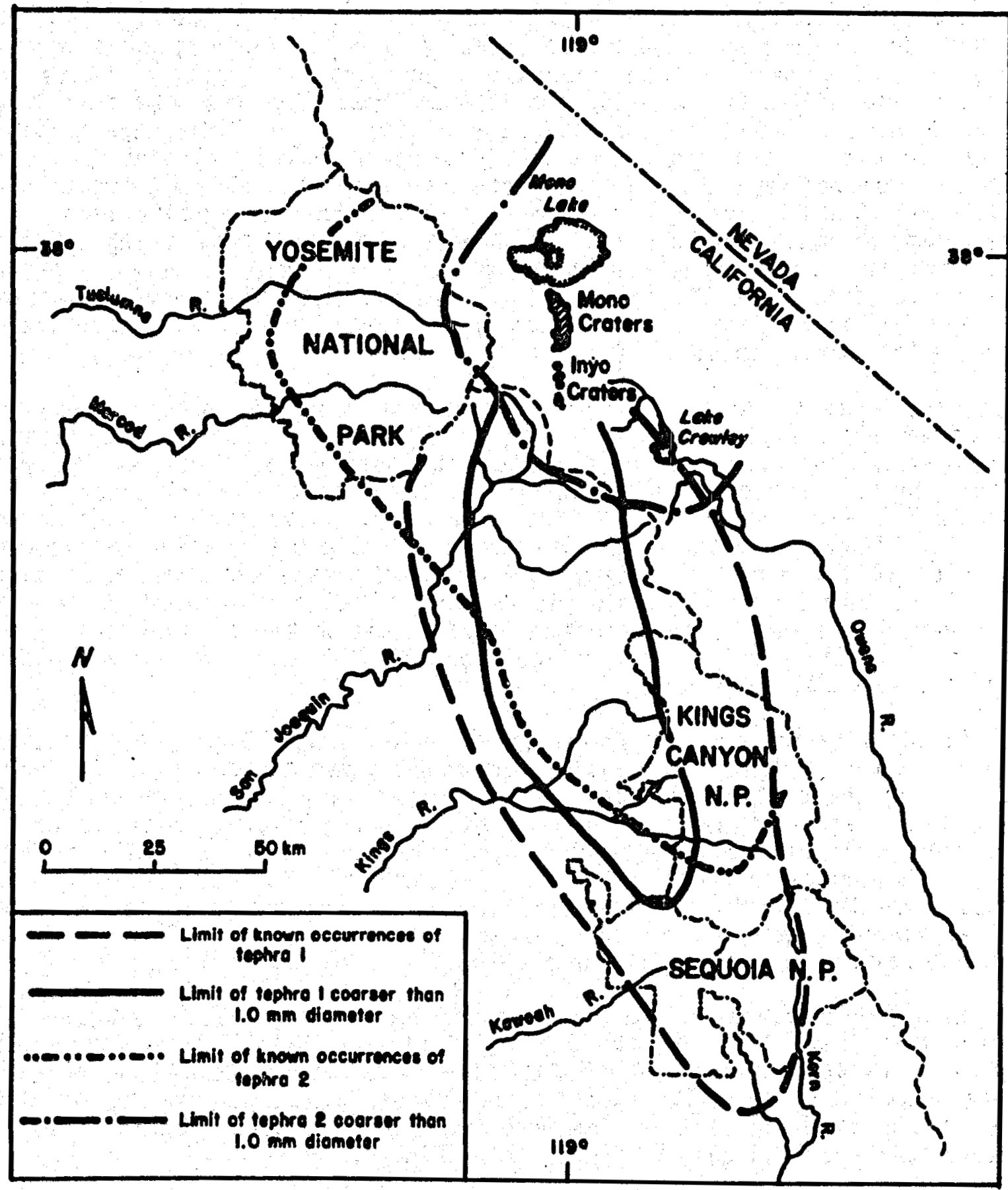

Figure 6. Areal distribution of tephra $1(720 \pm 60$ years before present) and tephra 2 (1190 \pm 80 years before present) layers. (Modified from Wood, 1977a, Figs. 3 and 4) 
Shortly after collapse of the caldera, the central part underwent resurgent doming during. Which rhyolite was erupted from at least twelve vents in the caldera. Doming and rhyolite extrusion in the central region were probably completed by 500,000 years ago, thus producing a "resurgent cauldron" with an uplifted central dome surrounded by a "moat" (Fig. 3). The next phase of Long Valley volcanism involved the emplacement of marginal (moat). rhyolites in three discrete episodes: $0.5,0.3$, and $0.1 \mathrm{m.y}$. ago. The moat rhyolites (Fig. 5), which were emplaced on the periphery of the central dome, are probabiy related to ring fractures around the resurgent dome. A later stage of volcanism produced rhyodacite in the western part of the caldera between about 180,000 and 50,000 years ago. The main mass of these rhyodacite flows comprises Mammoth Mountain. During late Pleistocene time, basalt and andesite flows were extruded in the west moat of the Long Valley caldera. Ages of these flows range from 222,000 to 62,000 years. Near the towns of Mammoth Lakes within the caldera and June Lake to the north, basalt flows are interbedded with glacial deposits.

Quaternary time in western North America has been characterized by the advance of alpine glaciers into temperate climatic zones. The eastern Sierra Nevada region has been glaciated at least eight times in the past million years; the naines and approximate ages of these glacial episodes are shown in Table 3 . During late Pleistocene and Holocene time, after the caldera had formed, widespread glacial activity along the southern and western boundaries of the Mono-Long Valley KGRA produced extensive deposits of till, particularly during the Wisconsin glaciations. Pleistocene time was also an age of waxing and waning lakes in the closed basins of the southwestern United States. Large lakes filled Long Valley about 500,000 years ago and Mono Basin during the past 100,000 years.

Volcanic activity in the Mono Craters chain began about 40,000 years ago, and a major episode of rhyolite extrusion occurred between 20,000 and 25,000 years ago. During the past 10,000 years, volcanic activity has increased markedly in the Mono Craters group. The rate of extrusion of rhyolite magma underwent a fourfold increase about 3000 years ago. Holocene volcanism has been episodic, with periods of dormancy ranging from 300 . to 2000 years between major events. The Mono Craters domes and flows were extruded along an arcuate, convex-eastward fracture zone that is believed to be a ring fracture of an incipient caldera, perhaps still underlain by a magma chamber.

The last major eruption in the Mono Craters occurred about 1200 years ago at Panum Crater (Fig. 1); near the north end of the chain. Tephra from this eruption blanketed a large part of the east-central Sierra Nevada region (Fig. 6) and also extended northeastward into western Nevada. Several rhyolite domes in the northern part of the Mono Craters postdate the tephra eruption and therefore are less than 1200 years old (Fig. 7.).

The most recent volcanic activity in the Mono-Long Valley region occurred in the Inyo Craters group (Fig. 8), along the northwest margin of the Long Valley caldera. Three of the Inyo domes are probably less than 800 years old. The Inyo domes and craters are inferred to lie along a north-trending fracture that extends from the Long Valley caldera to the Mono Craters along tire Sierra 
Nevada range front. An Inyo Craters eruption about 720 years ago produced a widespread tephra layer that blanketed much of the southern Sierra Nevada (Fig. 6) as far as the Little Kern River, $120 \mathrm{mi}(190 \mathrm{~km})$ south of the vent. The most recent volcanic event in the Mono-Long Valley region is believed to be the phreatic explosion that formed the southernmost Inyo crater (Fig. 8) around A.D. 1400.

Evidence abounds to show that the Mono-Long Valley region continues to be active geologically. Dormant volcanism manifests itself in the form of hot springs and fumaroles in the Long Valley caldera, warm water and carbon dioxide beneath Mono Craters, and a few hot springs in and around Mono Lake. Continuing tectonic activity has produced faulting in the Inyo Craters area that postdates the tephra layer dated at about 720 years. The "Earthquake Fault" near the town of Mammoth Lakes is part of this system of faults and fissures.

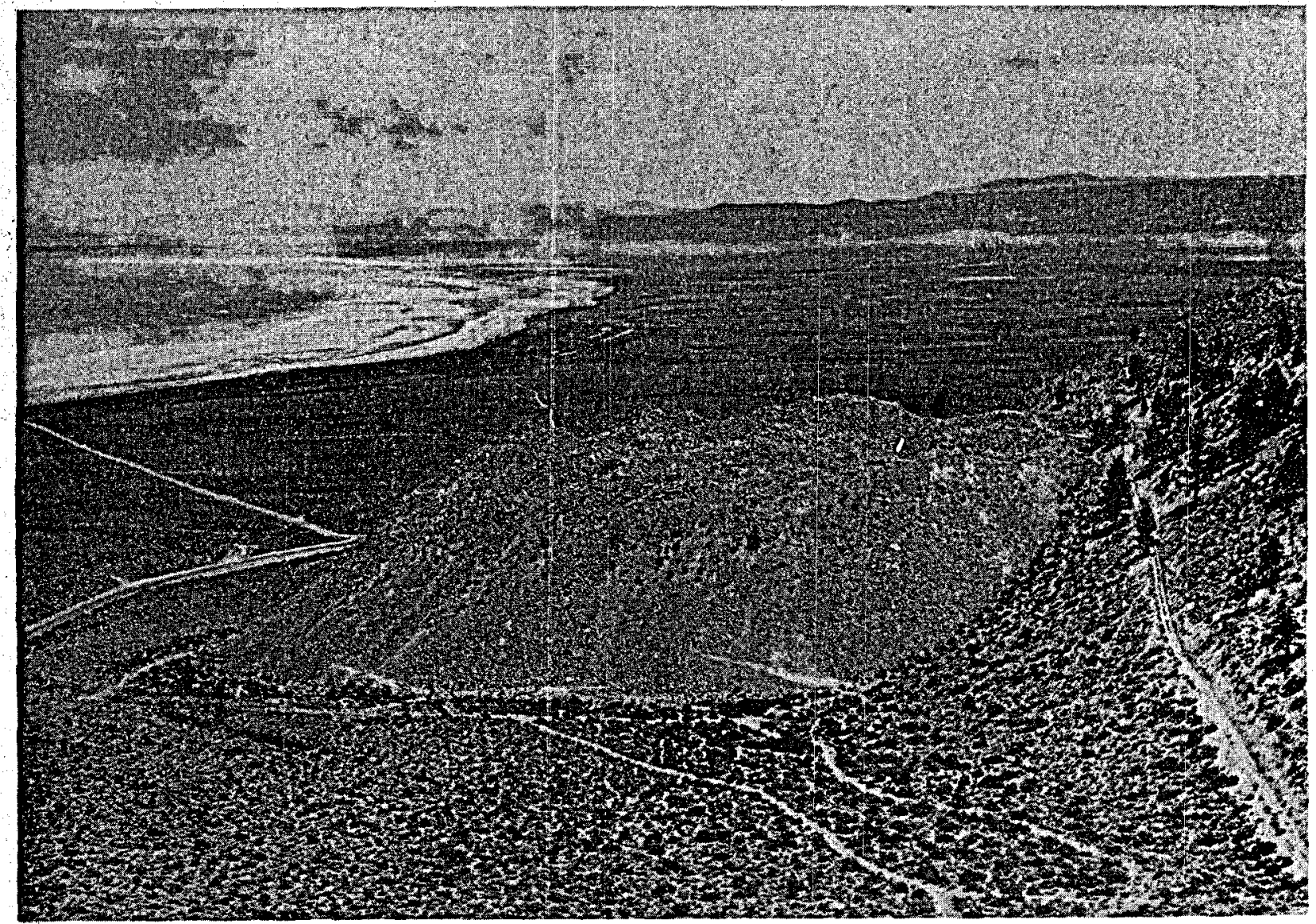

Figure 7. View east toward rhyolite dome near north end of Mono Craters chain. This dome, which is about $1200 \mathrm{ft}(365 \mathrm{~m})$ across at its base, has a sumnit crater consisting of a collapse depression within which lies an explosion crater (Smith, 1973, p. 2689). The dome has no tephra mantle and probably is less than 1200 years old (Wood, $1977 \mathrm{~b} ;$ p. 26). In the left distance is the south shore of Mono Lake. 


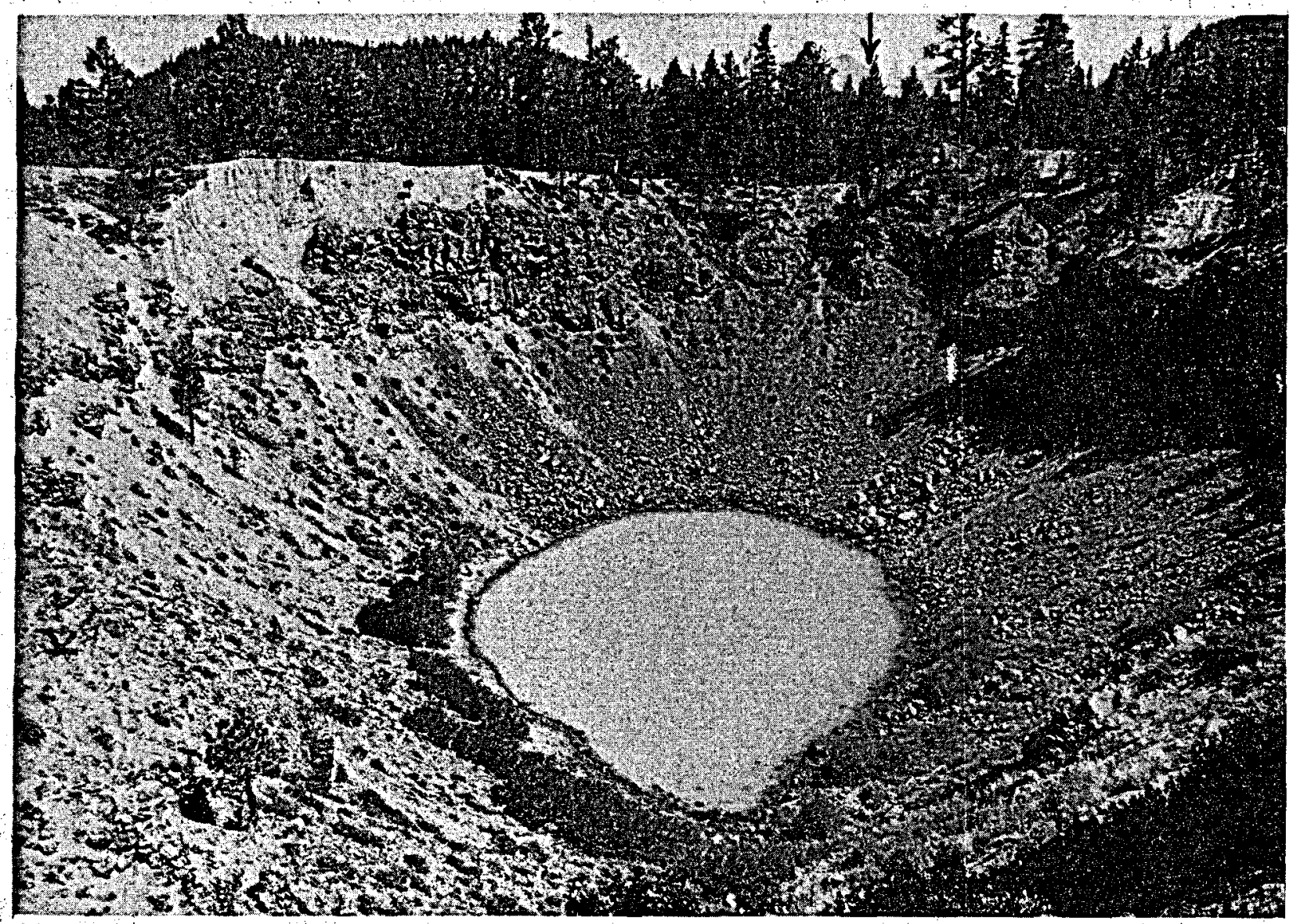

Figure 8. Southernmost of Inyo Craters, looking south. Arrow marks location of fault along which the east (left) block is relatively downdropped about $20 \mathrm{ft}(6 \mathrm{~m})$. The fault postdates the steam explosion that produced the crater around A.D. 1400. An andesite flow is exposed in the crater walls.

\section{IIKELY AREAS FOR GEOTHERMAL DEVELOPMENT}

In order to minimize the environmental impact of geothermal exploration, all available geological, geophysical, and hydrological data should be used to identify the most promising target areas for further geothermal evaluation. Identification of the most likely areas for geothermal development will aid in conducting further environmental assessment studies, inasmuch as different parts of the KGRA have different environmental concerns that need to be considered.

Mast of the geology of the KGRA has been mapped, and the Cowtrack Mountain quadrangle (east of the Mono Craters and southeast of. Mono Lake) is currently being mapped by the U.S. Geological Survey. The Long Valley caldera has been the subject of intensive geophysical studies, but only reconnaissance geo- 
physical information is available for other parts of the KGRA. Hydrologic information is sparse for the entire KGRA, although a tentative model has been developed for the hydrologic regime of the Long Valley caldera (Sorey et al., 1978). Workshop participants felt that little additional information about the caldera could be acquired by further geologlcal or geophysical studies. The consensus was that the main source of additional data would have to be deep drill holes (greater than $2000 \mathrm{ft}$ or $600 \mathrm{~m}$ ).

On the basis of the available information, by far the most likely area for geothermal development is the region about the resurgent dome of Long Valley caldera. The shallow heat reservoir at Casa Diablo Hot Springs has been tapped and is being used in a demonstration project to heat a lumberyard near Casa Diablo. The unpromising results of the wildcat geothermal well drilled in 1976 by Republic Geothermal, Inc. and the City of Burbank (Smith and Rex, 1977) has made the region east of the resurgent dome less attractive for further exploration efforts. Concentration of geothermal activities in the resurgent dome area would tend to minimize conflicts with other land uses, primarily urban and recreational, in the Mamnoth Lakes region.

Another possible region of geothermal interest is the Mono Craters-Pumice Valley area. Bailey et al. (1976, p. 735) suggest that a magma chamber may underlie Pumice Valley within the Mono Craters ring fracture zone. The magma chamber could be as much as $11 \mathrm{mi}(18 \mathrm{~km})$ in diameter and at depth greater than $2.5 \mathrm{mi}(4 \mathrm{~km})$ (Wood, $1977 \mathrm{~b}, \mathrm{p} .36-37$ ). No heat-flow anomaly is associated with the Mono Craters area, but the emplacement of magma may have occurred too recently (perhaps as recently as 40,000 years go) for the thermal anomaly to have propagated upward to the surface (Wood, 1977b, p. 37).

Some geothermal exploration has been undertaken in Mono Bas in, but Curry (1974, p. 7) reports that "geothermal drilling at Mono Lake was into granite with no conceivable prospect for economic use." Hence, almost nothing is known about the geothermal potential of the Mono Craters area inasmuch as no exploratory work has been done in the parts that are most likely to contain geothermal resources. If the Mono Craters area contains any comercial geothermal resources, the nature of the geothermal system ("hot water" or "hot dry rock") must be determined before a meaningful timetable for development can be proposed. The possible impact of any development in this area on spring flow also needs to be examined.

\section{MAJOR ENVIRONMENTAL ISSUES}

A number of environmental geologic factors that need to be considered during geothermal development were identified at the Mammoth Lakes workshop. These factors can be grouped in two broad categories, engineering geology and hydrology. Some of the factors are believed to be of major importance in Mono-Long Valley KGRA, and others are considered to be of minor importance. For many environmental factors, however, the data base is too sparse to allow an adequate determination of the factor's environmental effects during geothermal development. Environmental geologic considerations will be discussed 
in the following sequence, which is not intended to reflect their relative importance in Mono-Long Valley KGRA:

\author{
Engineering Geology \\ Seismicity \\ Microseismicity and induced seismicity \\ Large seismic events \\ Fault activity \\ Liquefaction \\ Surface deformation \\ Subsidence \\ Horizontal ground displacement \\ Slope stability \\ Erosion \\ Volcanic hazards \\ Hydrology \\ Effects of development on springs and groundwater \\ Effects of development on surface flow \\ Use of local water in cooling towers
}

It should be noted that most of the environmental geologic concerns are related to development of geothermal production, rather than to the exploration phase. The preponderance of development-related issues over explorationrelated issues is indicated in Table 5, which summarizes environmental concerns related to geology.

Seismicity

Microseismicity and Induced Seismicity

The relationship between microseismic activity and movement of geothermal fluids and cold groundwater at depth is not well understood at present for the Long Valley caldera. For other parts of the KGRA, no data are available to allow even an attempt to characterize such a relationship. Microseismicity may be a significant indicator of changes in the fracture system that provides the subterranean plumbing for the hydrothermal reservoir.

During production, geothermal fluids extracted from the Long Valley hydrothermal reservoir will eventually be reinjected into the reservoir. Injection of fluids may cause local changes in pressure within the reservoir that could initiate seismic activity. Such seismic activity induced by injection of fluids has been reported at the U.S. Army Rocky Mountain Arsenal near Denver (Healy et al., 1968, p. 1306) and in an oil field near Rangely, Colorado (Raleigh et al., 1972, p. 276). However, reinjection of waste fluids has not caused an increase in seismic activity in either The Geysers geothermal field (Ridley and Taylor, 1975, p. 1413) or the Otake, Japan, field (Kubota and Aosaki, 1975, p. 1383). The effect of reinjection upon seismic activity may be highly variable, being related to the rock properties and state of stress occurring in each area.

Observed changes in hot spring activity during 1973 also suggest that geothermal and seismic activity are related. On the night of August 24-25, a new group of at least five hot springs appeared near existing hot springs along 
Hot Creek, hours before a magnitude 3.5 earthquake occurred northwest of Bishop (Steeples and Pitt, 1973). On October 17,1973, additional hot springs appeared along Hot Creek within hours of another smal1 earthquake (Bailey et al., 1976, p. 738). Although the epicenters of these tremors were 12 to $25 \mathrm{mi}$ $\left(20\right.$ to $\left.40^{\circ} \mathrm{km}\right)$ from the site of the new springs, it is possible that the seismic activity altered the conduit system that feeds the hot springs. Monitoring of microseismicity prior to and during geothermal development would provide a data base for use in recognizing any development-induced microseismic activity. Such a monitoring system would require at least three continuously operating seismograph stations.

\section{Large Seismic Events}

The eastern escarpment of the Sierra Nevada is a seismically active zone, as evidenced by the great Owens Valley earthquake of 1872 and by the numerous earthquakes which have occurred along the escarpment since 1934, when publication of accurate epicenter data began (California Dept. Water Resources, 1964, map sheet 2). The epicenter of the 1872 earthquake was about $80 \mathrm{mi}$ (130 km) southeast of Mono-Long Valley KGRA, near the town of Lone Pine. The earthquake had an estimated magnitude of 8.3 and produced a surface break over $60 \mathrm{mi}$ (100 $\mathrm{km}$ ) long (Bonilla, 1970, p. 50). In the KGRA, the earthquake had estimated intensities of VII to VIII on the Modified Mercalli Scale (abridged scale defined by Richter, 1958, p. 137-138), based on eyewitness accounts (Oakeshott and others, 1972, p. 60). This intensity of ground shaking could cause major structural damage, including disruption of pipelines and geothermal wells. However, Jim Vantine (personal communication, 1979) reports that the seismic performance of oil wells in the Cook Inlet of Alaska and in California fields indicates that the wells are able to withstand considerable bedrock accelerations and durations of shaking. If well casings were to rupture, though, freshwater aquifers could be contaminated by hydrothermal fluids. Such contamination could be minimized by prompt repair of the ruptured well casing. In the event of a large earthquake, contamination of freshwater aquifers could also occur by natural development of fractures in the rocks.

The high seismicity of the eastern Sierra Nevada region is also manifested by the many earthquakes that have taken place during the past half century. Earthquakes of magnitude 6 that occurred in 1927 and 1941 had epicenters located south of Lake Crowley (California Dept. Water Resources, 1964, map sheet 2). The 1927 event probably was associated with the Hilton Creek fault (Fig. 9), and the 1941 event may have been related to the same fault.

Lesser seismic events also have occurred in the region, including a 1940 earthquake of magnitude 4.5 which had its epicenter near the Hot Creek Fish Hatchery and a 1951 earthquake of magnitude 4.0 centered east of Paoha Island in Mono Lake (California Dept. Water Resources, 1964, p. 61, 63). On October 4, 1978, a moderate earthquake of magnitude 5.7 caused rockslides at Mammoth Lakes and Yosemite National Park and broke windows in Bishop (Ramos, 1978). The quake was centered about $2 \mathrm{mi}(3 \mathrm{~km})$ south of Toms Place, near the southeast corner of Mono-Long Valley KGRA (Richard Saul, California Div. Mines and Geology, oral communication, 1978). Aftershocks of the trenor had magnitudes as high as 4.8 and 4.3 and were felt in Yosemite. The main shock was felt in a region from Sacramento to Bakersfield and Tehachapi (Ramos, 1978). This event probably was associated with the Sierra Nevada frontal fault system, as was the 1872 earthquake. 
Large seismic events that affect the Mono-Long Valley region are monitored by the seismograph networks of the University of California at Berkeley, Caltech, the University of Nevada at Reno, and the U.S. Geological Survey. As a result of this coverage, an adequate record of post-1933 earthquakes of magnitude 4 and greater exists for the region. This record provides information on the magnitudes of events with short recurrence intervals, and this information can be utilized in planning any geothermal development in the region.

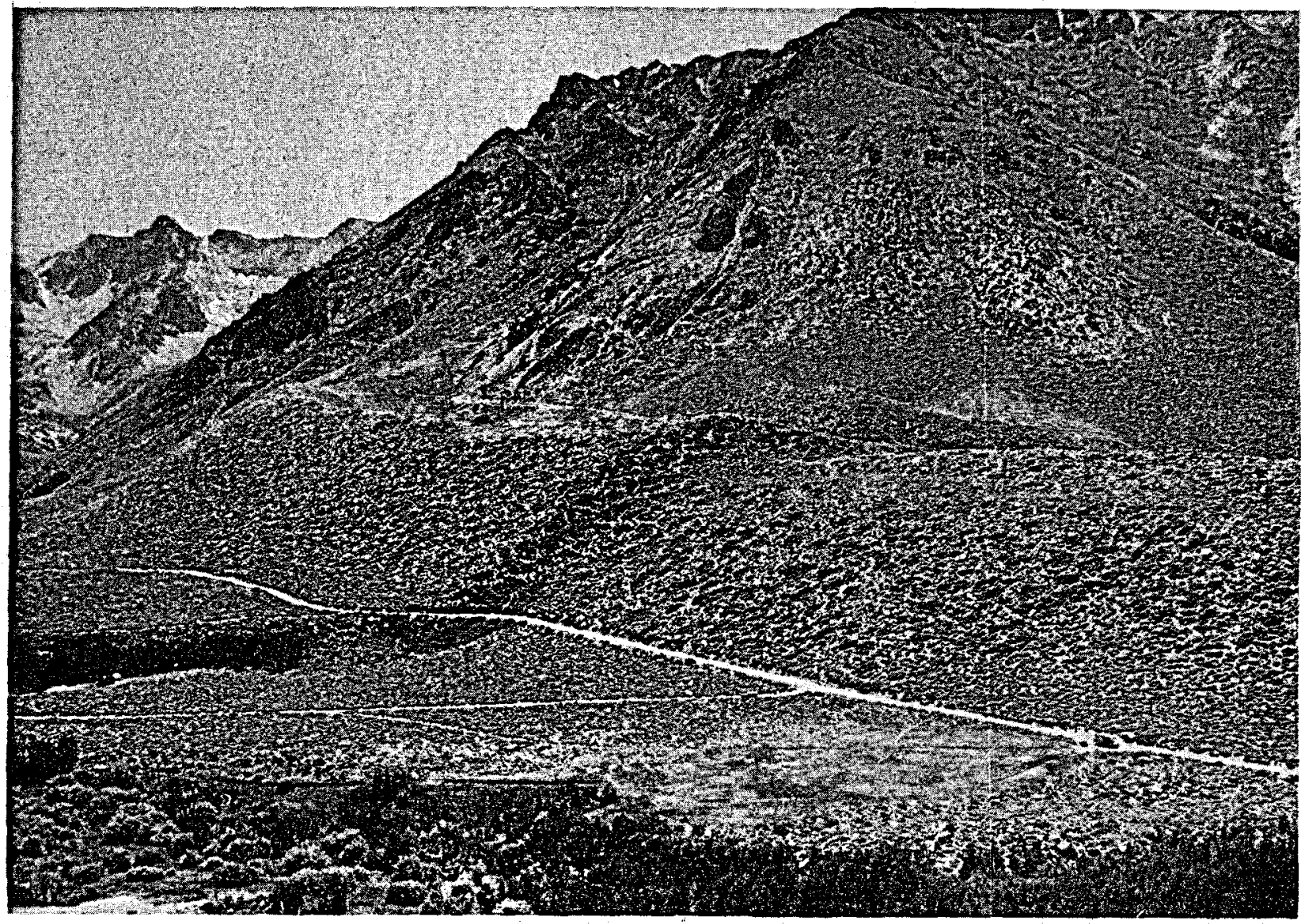

Figure 9. Scarp of Hilton Creek fault crossing Tioga (late Wisconsin) moraine along McGee Creek. Scarp is $50 \mathrm{ft}(15 \mathrm{~m})$ high. McGee Creek flows from left to right (northward) through the trees at the bottom of the photo.

\section{Fault Activity}

Faults of the Mono-Long Valley KGRA are of interest for two reasons: their potential for seismic activity, and their influence on the groundwater hydrologic regime. The great majority of faults in the KGRA, including all faults in the Long Valley caldera, have been active during Quaternary time. There is no universally accepted definition of what constitutes an active fault, but the U.S. Atomic Energy Commission (AEC) established 
fault activity criteria for nuclear reactor sites. They considered a fault to be active if it has moved at least once in the past 35,000 years, or more than once in the past 500,000 years (Nichols and Buchanan-Banks, 1974, p. 2). Using the AEC criteria, numerous faults in Mono-Long Valley KGRA can be considered to be active. Of these faults, perhaps the ones of greatest interest to geothermal development are the Sierra Nevada frontal fault system, the Hilton Creek fault (Fig. 9), the southern boundary fault of the Long Valley caldera, and the Hartley Springs fault (Fig. 2). Related to the Hartley Springs fault is the system of north-trending faults and fissures that extend between Mammoth Mountain and the south end of the Mono Craters chain; some of these fractures show evidence of Holocene activity.

Although ground motion is a much greater seismic hazard than is surface rupture, the latter may be important to geothermal development because most surface manifestations of hydrothermal activity are associated with Quaternary faulting. Hence, geothermal facilities (such as power plants and pipelines) may tend to be situated near fault zones and be susceptible to damage related to ground rupture. Not all Quaternary faults of the region are necessarily active, though. For example, most faults that cut the resurgent dome of the caldera are related to formation of the dome and are now probably inactive.

The historic seismic record indicates that earthquakes of magnitude 6 have a high probability of occurring in the region during the course of any geothermal development. In order to assess the ground motion resulting from large events, an estimate of the maximum expectable earthquake would have to be made for each active fault. For example, the maximum expectable earthquake on the southern boundary fault of the Long Valley caldera is estimated to have a magnitude of 6.5 (Lipshie, 1974, p. 121). Any plan for geothermal development would need to include an evaluation of the potential for damage to structures (including wells and pipelines) as a result of a moderate or strong earthquake. Extensive geologic mapping in the Long Valley caldera, the area most likely to undergo geothermal development, has delineated the surface traces of numerous Quaternary faults (Bailey, 1974; Bailey and Koeppen, 1977). The remainder of the KGRA has been mapped in reconnaissance or at a scale of $1: 62,500$, so the fault pattern there is less well documented than that within the Long Valley caldera.

In addition to providing conduits for the movement of hydrothermal fluids, faults may also affect the hydrologic regime by acting as groundwater barriers. Sorey et a1. (1978, p. A46) suggest that the Hilton Creek fault may act as such a barrier, separating cool water on the east from hot water on the west. Fault movement that disrupts the self-sealing effects of hydrothermally altered fault zones could cause significant changes in the areal extent of the geothermal reservoir by permitting lateral infiltration of cool groundwater. Fault movement might also affect hot spring and fumarole activity by opening new hydrothermal conduits or sealing old ones, thus altering the plumbing that links the surface geothermal activity with its source reservoir. Hence, faulting could affect the longevity of production from the geothermal field.

\section{Liquefaction}

The potential for loss of soil strength by liquefaction during moderate- to large-magnitude earthquakes is an indirect environmental consideration 
in that it may need to be taken into account in selecting sites for any geothermal facilities. Much of the Mono-Long Valley region is blanketed with a pumice soil that is very porous and permeable. In some of the lowlying areas, the soil could become saturated with a large volume of groundwater during the spring melting of snow. If an earthquake were to occur during this period of saturation, the soil could become liquefied.

Seed and Idriss (1971, p. 1250) report that loose, sandy soils with a low relative density (high void ratio), like the pumice soil of the Mono-Long Valley region, are more prone to liquefy than are soils which are more compacted. For example, during the Mexico City earthquake of 1962, a layer of soft volcanic ash soil several hundred feet (about a hundred meters) thick "behaved like a bowl of jelly" (Housner, 1970, p. 82), although whether the soil actually liquefied was not made clear. Proposed construction sites that are underlain by water-saturated pumice soil may not be suitable for geothermal facilities if the soil's liquefaction potential is found to be excessive. Although each site would have to be evaluated individually by qualified soils engineers, liquefaction is not expected to be a major problem in any development of geothermal resources in the Mono-Long Valley. KGRA. There should be a sufficient number of acceptable construction sites so that areas of high liquefaction potential can be avoided.

\section{Surface Deformation}

Horizontal and vertical ground displacement is an environmental concern because such movement could rupture well casings and lead to well blowouts or groundwater contamination by geothermal fluids. Surface deformation could also result in major structural damage to geothermal production facil-. ities.

\section{Subsidence}

Vertical displacement of the ground, particularly subsidence, can result from extraction or injection of fluids during geothermal production. Subsidence of up to $28 \mathrm{ft}(8.5 \mathrm{~m})$ has occurred in the San Joaquin Valley owing to extraction of groundwater (Green, 1973, p. 79). 0il production from the Wilmington field caused up to $29 \mathrm{ft}(9 \mathrm{~m})$ of subsidence in Long Beach, but some of the lost elevation (about a foot or $0.3 \mathrm{~m}$ ) was recovered by water injection during 1966-1970 (Allen, 1973, p. 104, 109). However, the reservoir rocks in the San Joaquin Valley and at Wilmington consist of sedimentary materials, whereas the Long Valley deep reservoir occurs principally in Bishop Tuff. Hence, these two cited examples may not be directly applicable to Long Valley, inasmuch as the compressibilities of sedimentary deposits and Bishop Tuff may differ markedly.

Subsidence during testing and production has been reported from three geothermal fields in New Zealand (Stilwell et al., 1975). The Wairakei field subsided a maximum of $8 \mathrm{ft}(2.4 \mathrm{~m})$ between 1952 and 1964 and an additional 15 ft $(4.5 \mathrm{~m})$ between 1964 and 1974 . The first well was drilled at Wairakei in 1950, and power plants were built there in 1958 and 1964. Subsidence has been accompanied by horizontal ground displacements, and some steam pipe sections have had to be replaced. Subsidence rates of $18 \mathrm{in.} / \mathrm{yr}(450 \mathrm{~mm} / \mathrm{yr})$ at Wairakei, $3 \mathrm{in./yr}(75 \mathrm{~mm} / \mathrm{yr})$ at Broadlands, and $1.1 \mathrm{in.} / \mathrm{yr}(28 \mathrm{~mm} / \mathrm{yr})$ at Kawerau have been reported for New Zealand geothermal fields (Stilwell et al., p. 
1431, 1434). Stilwell et al. (p. 1427) indicate that reinjection is not being employed in the New Zealand fields, although it is being considered as a means of reducing subsidence and stream pollution.

Any geothermal production in Mono-Long Valley KGRA probably would involve a closed system of circulation, in which fluids extracted from the hydrothermal reservoir are reinjected. Because of this closed circulation, subsidence is not expected to be a serious problem in the KGRA. Assuming that the present land-use pattern continues, any subsidence that occurs as a result of geothermal development would be centered away from the built-up areas. However, if significant quantities of groundwater were extracted for use in cooling towers of geothermal power plants, subsidence could become a major concern. Reinjection of coolant water might be undertaken to mitigate subsidence problems:

No published data on subsidence are presently available for areas of geothermal interest in the KGRA. As part of the 1972-73 investigation of the Long Valley caldera by the U.S. Geological Survey, Ben Lofgren conducted a releveling survey of the region in order to estabilish a data base for future geothermai studies. The data from this survey are available from the Topographic Division of the U.S. Geological Survey.

\section{Horizontal Ground Displacement}

Horizontal displacement of the ground comnonly is associated with subsidence, as at Long Beach, where $12 \mathrm{ft}(3.7 \mathrm{~m})$ of horizontal movement was associated with $29 \mathrm{ft}(9 \mathrm{~m})$ of vertical movement (Allen, 1973, p, 111). Horizontal ground displacement also may be due to tectonic activity, either local or regional. Aseismic fault creep caused by geothermal development intght be manifested by horizontal ground movement that could be detected by geodetic surveys. No data base for such surveys in the Mono-Long Valley KGRA has been published, but baseline data are available from the Topographic Division of the U.S. Geological Survey. Horizontal ground displacement is not expected to be a significant problem in the areas of geothermal interest.

Slope Stability

In the Geysers-Calistoga KGRA, slope stability has been a major environmental geologic concern because of the nature of the geologic substrate there. In that area, the presence of serpentinite and sheared rocks of the Franciscan assemblage (mostly sandstone and shale) has resulted in landsliding, differential settlement, and accelerated erosion in areas of geothermal development (Bacon et a1., 1976, p. 7-8, 11). The rocks of Mono-Long Valley KGRA consist mostly of basalt and rhyolite flows, domes, and tuffs in the areas of greatest geothermal potential. Because of the natural stability of these volcanic materials, landsliding and related slope instability are not expected to be significant hindrances to geothermal development. However, slope stability problems could occur during development in areas underlain by hydrothermally altered volcanic rocks. Hydrothermal alteration to clay and opal is common in areas of geothermal interest in the Long Valley caldera.

It should also be noted that liquefaction can cause slope failure in very gently sloping terrain, if the slope material has a high liquefaction potential. Such a failure occurred during the San Fernando earthquake of 1971, 
when liquefaction triggered a landslide $0.75 \mathrm{mi}(1.2 \mathrm{~km})$. long in an area with a slope of about $1.5^{\circ}$ (Youd, 1971). Detailed geologic studies and engineering tests could identify areas that might be susceptible to liquefactioncaused slope instability.

\section{Erosion}

Under normal conditions of development, accelerated erosion is not likely to be a problem in Mono-Long Valley KGRA. The most likely source of accelerated erosion is construction activity and road building during geothermal development. This source of erosion can be controlled by proper engineering during construction and should not hinder development.

If a blowout were to occur, a localized erosion problem could result. In The Geysers geothermal field, blowouts that occurred in 1957 (McNitt, 1963, p. 15) and 1975 (Bacon and others, 1976, p. 33) caused local erosion, the latter blowout eroding a crater about $120 \mathrm{ft}(35 \mathrm{~m})$ across and $25 \mathrm{ft}$ ( 7.5 m) deep. Although blowouts could produce severe local erosion, the geologic substrate in the areas most likely to undergo geothermal development should not be susceptible to accelerated erosion if the development sites are carefully selected and engineered.

\section{Volcanic Hazards}

Two types of volcanic hazards need to be considered for the Mono-Long Valley region: quiet extrusion of basaltic lava flows, and explosive eruption of high-silica volcanic material. Within the past 1500 years, a number of explosive eruptions from the Inyo-Mono Craters chain and Marmoth Mountain have blanketed the region with pumice fragments. Wood (1977a, p. 92-94) has identified two widespread tephra layers that were produced by eruptions in the Inyo Craters group about 720 years ago and the Mono Craters chain less than 1200 years ago (Fig. 6 ).

A repetition of these explosive eruptions is the most serious volcanic hazard in the KGRA for two reasons: (1) pumice eruptions have occurred much more recently than the youngest basalt flows and are therefore more likely to recur in the future than are the flows, and (2) an explosive eruption, because of its violence and suddenness, could result in loss of life and substantial property damage. Although premonitory seismic or fumarolic activity may precede the onset of volcanic eruptions, the historical record indicates that the duration of precursory activity is highly variable and that some eruptions may occur virtually without warning (Lipshie, 1974, P. 109). Wood (1977c) has projected the recent rate of lava extrusion for the Mono Craters to suggest that a future eruption could release as much as $0.25 \mathrm{cu}$ mi (1 cu $\mathrm{km}$ ) of lava.

The recurrence frequency of explosive volcanic eruptions during the past 1500 years suggests that another explosive eruption blanketing a large area with pumice ash could reasonably be expected to occur in the next 500 years. However, a meaningful assessment of the probability of such an eruption or the nature of its effects cannot be made with present knowledge. No conclusive evidence exists from developed geothermal areas around the world to suggest that geothermal development affects major eruptive activity, either in retarding or intensifying the rate of lava extrusion. 
Mammoth Mountain, $6 \mathrm{mi}(10 \mathrm{~km})$ west of Casa Diablo Hot Springs (Fig. 1$)$, is a dormant volcano that continues to manifest signs of geothermal activity. Fumaroles have been reported by Huber and Rinehart (1967, p. D19) and Curry (1971, p. 4) on the sumit and flanks of the mountain. If a major eruption of Mamnoth Mountain were to occur, debris flows or hot, gas-charged ash- and block-flows (nuees ardentes) could devastate the town of Marmoth Lakes and damage geothermal production facilities in the Long Valley caldera. Such debris flows and volcanic eruptions have occurred at Mammoth Mountain on various occasions since the Tahoe glaciation (Table 3) and could conceivably occur again. However, there is no evidence that geothermal development in the region would influence the likelihood of future eruptions at Mammoth Mountain.

\section{Effects of Development on Springs and Groundwater}

The effects of exploratory drilling and subsequent development on the thermal and cold springs of the Mono-Long Valley KGRA have not been determined. The primary concern is the effect of development on the thermal springs, particularly those along Hot Creek south and east of the resurgent dome of the Long Valley caldera. The Hot Creek springs, because they are used for raising trout at the State fish hatcheries and for recreation farther downstream, are considered to be "sensitive resources." Past experience suggests that geothermal drilling in the area may affect hot spring activity: the completion of nine wells between 1959 and 1962 at Casa Diablo Hot Springs apparently caused the hot spring there to dry up (G.S. Smith, 1976, p. 20-21). It is possible, though, that the change in the Casa Diablo hot spring was a natural occurrence unrelated to, but coincident with, geothermal drilling. Jim Vantine (personal comunication, 1979) reports that in The Geysers area, where geothermal development has been underway since the early $1920^{\prime} \mathrm{s}$, extraction of geothermal resources has had a negligible effect on hot springs there.

The geothermal wells at Casa Diablo Hot Springs tap a heat reservoir at shallow depths. Development at Casa Diablo, because it involves a shallow aquifer, may affect shallow groundwater, both hot and cold, more than would development of the primary deep hydrothermal reservoir. Any adverse effects on shallow aquifers might have compounding effects on such surface environmental conditions as vegetation or air-borne dust.

Spring water used by the Hot Creek Fish Hatchery is a natural mixture of hot and cold water with a hot-water portion ranging between 1 and 3 percent (Sorey, 1976, p. 5). Temperatures of these tepid springs are between $12^{\circ} \mathrm{C}$ and $17^{\circ} \mathrm{C}$ (Lewis, 1974, p. 28), which has been found to be an optimum temperature range for breeding trout. A decrease of $3.5^{\circ} \mathrm{C}$ in the temperatures of the hatchery springs would have an adverse effect on productivity of the breeding operation (Sorey, 1976, p. 7). Sorey (p. 8) suggests that adverse effects might be mitigated by supplementing the natural spring flow with hot water from geothermal wells to maintain optimum temperatures at the hatchery. Contamination of spring water by geothermal fluids, which could be a problem to the fish hatchery or the municipal supply watershed, is discussed in the chapter of this report that deals with environmental issues of water quality.

Recreational use of Hot Creek includes fishing throughout its length and swiming at the hot springs $2.5 \mathrm{mi}(4 \mathrm{~km})$ northeast of the fish hatchery. Changes in spring flow, temperature, or chemistry due to yeothermal develop- 
ment could interfere with recreational activities along Hot Creek. Monitoring of hot and cold spring activity before and during development would be useful in order to identify any changes resulting from geothermal development. Furthermore, as Sorey et a1. (1978, p. A22) point out, the concentrations of boron and chlorine in the water, measured as a part of such monitoring, can be used to determine the relative proportions of hot and cold groundwater contributions. Continuous temperature and occasional chemical monitoring of the fish hatchery springs are done by the California Department of Fish and Game.

Insofar as the potential effects of geothermal development upon groundwater are concerned, the primary environmental consideration is the possible contamination of shallow freshwater aquifers by hydrothermal fiuids. This is primarily an issue of water quality and is discussed at length in that chapter of this report. Any development-induced changes in groundwater conditions could be detected by the use of observation wells to monitor the groundwater. But because groundwater circulation is a relatively slow process, any development-induced effects might not be detected until years after the change had been introduced.

Effects of Development on Surface Flow

Geothermal development could possibly affect stream flow in various ways: (1) if coolant water is released into the streams, it could alter the stream temperatures; (2) leakage of geothermal fluids could change the stream chemistry; (3) escape of drilling fluids during field development could contaminate the streams; and (4) geothermal development might affect the springs that feed the streams, as discussed above. Because the streams of the MonoLong Valley region are used for both recreation and water supply, any decrease in their suitability for either purpose as a result of geothermal development could seriously restrict geothermal exploration and production in the KGRA. Hot Creek, Owens River, and Lake Crowley are particularly sensitive areas, inasmuch as they are the most intensively fished waters.

Use of Local Water in Cooling Towers

If geothermal resources of the KGRA are developed for generation of electric power, cold water may be needed for the cooling towers of power plants. The surface water supply in the Mono-Long Valley region is very limited, and the LADWP and Mammoth County Water District have essentially all of the surface water rights. Availability of water tributary to the Los Angeles water supply system, and in fact the long-term supply for southern California, is somewhat unreliable owing to uncertain developments associated with both the Colorado and California Aqueducts. Furthermore, the holders of riparian water rights, including the California Department of Fish ahd Game, would presumably be concerned about any use of surface water that might result in increased temperature or degradation of water quality. Hence, if water is needed for use in cooling towers, geothermal power plants would probably have to rely on groundwater, and the extent and reliability of the groundwater supply has not yet been evaluated. The limited availability of coolant water for geothermal power plants could conceivably be a major obstacle to development. It is possible, though, that very little, if any, coolant water will -be required, depending upon the resource found and the technology employed. In that case, a potentially serious obstacle to development could be removed. 


\section{DATA GAPS AND SOURCES, AND SUGGESTED PROJECTS}

In some cases, the information avallable is insufficient for assessing the impact of the environmental considerations enumerated in the section entitled "Major Environmental Issues." These data gaps are discussed herein, and possible studies to acquire needed information are suggested. The dataacquisition projects suggested in this section are summarized in Table 4.

\section{Seismicity}

The only part of Mono-Long Valley KGRA for which microseismic data are available is the Long Valley caldera, for which about two months of data were collected by the U.S. Geological Survey (Pitt and Steeples, 1975; Steeples and Pitt, 1976). It would be desirable to get a larger data base to use for comparison with post-development microseismicity in order to Identify any changes attributable to geothermal development. If development occurred, a larger data base would be in the best interests of the geothermal field operators, to provide documentation of the effect of development on induced seismicity in the area. A larger data base would al so permit the recognition of seasonal fluctuations in microseismic activity. Any fluctuations that were related to seasonal changes in groundwater regimes (flow, temperature, and water table) would be expected to be approximately periodic, with an annual periodicity. Such seasonal variations might be mistaken for developmentinduced changes if the natural fluctuations are not identified beforehand. However, acquisition of microseismicity data is a relatively expensive process, and workshop participants did not reach a consensus on how much additional pre-development monitoring of microseismicity would be practical.

Data on large seismic events are available in various state and federal publications. For the Mono-Long Valley region, the four primary tabulations of earthquakes are the California Department of Water Resources (1964) bullet in which lists events of magnitude 4 or greater for the period 1934-1961, the compilation by Bolt and Miller (1975) covering the period 1910-1972, the catalogue by Hileman, et al. (1973) for the period 1932-1972, and the 19721974 supplement to the latter reference by Friedman et al. (1975). In addition to these catalogues, the Owens Valley earthquake of 1872 is discussed by Oakeshott et al. (1972). Any studies of large seismic events would be done mainly by the developers of geothermal resources.

\section{Fault Activity}

Detalled mapping of faults in the Long Valley caldera and environs is available as U.S. Geological Survey open-file reports (Bailey, 1974; Bailey and Koeppen, 1977). For other parts of the KGRA, faults have been mapped in less detail, either for quadrangle maps at a scale of $1: 62,500$ or for regional reconnaissance maps at smaller scales. Fault activity may affect eruptive activity in the region. For example, Wood (1977b, p. 25) has suggested that eruptive vents in the northern Mono Craters chain lie at the intersections of northeast-trending fractures with the northwest-trending extension of the ring-fracture zone. 
TABLE 4

SUGGESTED PROJECTS TO ACQUIRE ADDITIONAL DATA FOR

USE IN ASSESSING THE ENVIRONMENTAL EFFECTS OF GEOTHERMAL DEVELOPMENT IN MONO-LONG VALLEY KGRA.

\section{Environmental concern}

Microseismicity and induced seismicity

Fault activity

Liquefaction potential

Surface deformation

Slope stability

Volcanic hazards

Effects of development on springs and streams

\section{Effects of development} on groundwater (shallow aquifers)

Assessment of geothermal resources

\section{Project}

Monitoring of microseismic activity prior to and during development; would require at least 3 seismograph stations.

Trenching across faults that are known or suspected to be active.

Seismic risk analysis for active faults of the eastern Sierra Nevada region.

Evaluation of liquefaction potential at construction sites for geothermal facilities; would be responsibility of developers.

Additional releveling surveys before development to supplement U.S. Geological Survey baseline data; also periodic resurveys after geothermal production begins.

Engineering and geologic studies of slope stability for proposed construction sites; would be responsibility of developers.

Monitoring of geothermal and seismic activity, particularly at Mammoth Mountain and in the Inyo-Mono Craters chain.

Monitoring flow, temperature, and chemistry of cold and hot springs and streams prior to and during development.

Drilling of shallow wells and monitoring of temperature, chemistry, and water table level before and during development.

Drilling of deep exploratory wells in Long Valley; comprehensive geophysical studies in the Mono Craters region. These projects would probably be partly or entirely the responsibility of the private sector. 
If more detailed information on the Quaternary history of faulting is sought, trenching of selected fault zones might be necessary. Such information might be required in order to evaluate possible sites for construction of geothermal facilities. Trenching could provide information on earthquake recurrence intervals and perhaps provide a better understanding of the state of stress in the rocks of the area. Information about the state of stress could be used in assessing the possibility of induced seismicity resulting from development. But information on fault activity is a relatively low-priority environmental concern that would be primarily the responsibility of the developers.

\section{Liquefaction}

Very little information is available regarding the liquefaction potential of soils of the Mono-Long Valley region. Although liquefaction hazards are unlikely to be a serious obstacle to geothermal development, developers would need to evaluate each proposed construction site separately for liquefaction potential.

\section{Surface Deformation}

A releveling survey conducted by Ben Lofgren for the U.S. Geological Survey is the only detailed survey carried out within the Mono-Long Valley KGRA. The survey was undertaken to establish a pre-development base level for use in detecting subsidence or horizontal ground displacement due to geothermal production. Data from the Lofgren study have not been published but are available from the U.S. Geological Survey. Although surface deformation is not expected to be a problem, it may be desirable to supplement the Lofgren survey with additional geodetic data. If so, any additional geodetic surveying for baseline purposes could be done either before or during exploration drilling but should be completed before the start of any production.

\section{Slope Stability and Erosion.}

In the likely areas of geothermal development, slope instability and accelerated erosion are unlikely to be problems. No slope stability or erosion data are available for Mono-Long Valley KGRA, except for a brief general discussion of slope stability by Lipshie (1974, p. 127-130, 137-138). It may be necessary to conduct slope-stability studies for some proposed sites of geothermal facilities. Accelerated erosion could become a problem, albeit highly localized, if blowouts were to occur.

\section{Volcanic Hazards}

The likelihood of future volcanic eruptions in the Mono-Long Valley region cannot be evaluated with any degree of reliability. Various workers (e.g. Curry, 1971, p. 4; Lipshie, 1974, p. 110; Bailey et a1., 1976, p. 735; Wood, $1977 \mathrm{~b}, \mathrm{p} . \mathrm{s}^{3}$ ) have discussed the possibility of future volcanic eruptions in the region, particularly the explosive eruptions of rhyolitic magma such as have occurred repeatediy in the past 3000 years. Although such an eruption could have catastrophic effects, there are no effective preventive measures that can be taken to protect against volcanic hazards. As one precaution, however, geothermal and seismic activity could be monitored, inasmuch as any major change in activity might be a precursor of renewed volcanism. In selecting sites for geothermal facilities, it would be advisable to avoid 
valleys downstream from volcanic vents. Such valleys might act as natural channels for debris flows or hot, gas-charged ash- and block-flows if volcanic eruptions were to occur again. Based on the Holocene record of volcanic activity in the region, the most likely site of future eruptions is the Inyo-Mono Craters chain.

\section{Hydrologic Effects of Development}

The principal sources of hydrologic data, published and unpublished, are government agencies: the U.S. Geological Survey, U.S. Forest Service, California Department of Water Resources, California Department of Fish and Game, Los Angeles Department of Water and Power, and Mammoth County Water District. Publications on hydrology of the region are mentioned in the "Surface Hydrology" section of this chapter.

Much more hydrologic information is available for the Long Valley caldera than for the remainder of the KGRA. This is primarily due to the fact that the U.S. Geological Survey selected the caldera as the type area for hot-water geothermal systems and studied it intensively during the early 1970's. The results of this project were published in the February 10,1976, issue of the Journal of Geophysical Research. Sorey et al. (1978) synthesized the results of these studies to develop a model of the hydrologic regime of the caldera. Workshop participants felt that further information about the caldera's hydrologic system must come from deep drilling rather than from additional surface geological or geophysical investigations.

Relatively little is known about the Mono Basin hydrologic system and subsurface geologic structure, and virtually nothing is known about its geothermal potential. Lee's (1969) hydrogeologic study contains most of the available information on the basin's hydrology. If a geothermal reservoir is present in the Mono Craters region, it could be either a "hot water" or a "hot dry rock" system. Much reconnaissance exploratory work needs to be done in Mono Basin to acquire basic data (mostly geophysical) needed in order to begin evaluating the geothermal potential of the Mono Craters area. As Curry (1974, p. 7) has pointed out, previous exploratory drilling in Mono Basin (Axtell, 1972) did not test the regions most likely to contain geothermal resources.

In the Long Valley caldera, which is the area most likely to undergo geothermal development, hydrologic considerations may be the most serious barrier to geothermal development. Any conflicts between geothermal operations and other uses of water resources will have to be resolved if development is to proceed. Various government entities will undoubtedly be vigilant in protecting their interests in water resources or their rights thereto: the California Department of Fish and Game at the Hot Creek Fish Hatchery, the U.S. Forest Service for the recreation areas along Hot Creek and the Owens River tributaries, the LADWP for its riparian water rights to Hot Creek and the Owens River and its Lake Crowley reservoir, and the State Water Quality Control Board for protection of overall water quality.

Monitoring of streams and springs before and during development would be desirable in order to establish a data base and detect any changes that might result from geothermal development in the region. Some stream and spring data are currently available (e.g., California Dept. Water Resources, 1967 and 1973; Lewis, 1974; Lipshie, 1974; Mariner and Willey, 1976; unpublished LADWP 
data), but additional measurements of flow, temperature, and chemistry would help to augment the present data base. Additional pre-development monitoring would provide supplemental information on the natural variations, such as seasonar fluctuations, in spring and stream activity. Any hydrologic changes due to seismic activity might also be identified by such monitoring. Hot Creek and the Owens River would be the most 11kely streams to monitor; the fish hatchery springs and the springs along Hot Creek would be the most useful springs to monitor. Such monitoring of flow and quality could provide an important data base if questions arise regarding the possible infringement of geothermal operations on the riparian water rights of downstream landholders, particularly the LADWP.

Very little is known about circulation between groundwater reservoirs and spatial distribution of aquifers, nor is much known about the relationship of groundwater to surface water flow. Further information to charactertze the groundwater hydrology of the caldera would have to be derived from well data. Shallow wells would also be needed in order to monitor any effects of geothermal development on shallow aquifers. The chemistry of well water could be analyzed to detect any contamination and to "fingerprint" the sources of water, using boron and chlorine content to determine the degree of mixing of hot and cold water. Long-term monitoring of the shallow groundwater regime would be relatively inexpensive and could provide useful information prior to and during any development.

Before geothermal production is undertaken in Long Valley, the heat reserves must be evaluated to determine the form that geothermal development will take: space heating or generation of electric power. If geothermal resources are inadequate for generating electricity, it may be possible to develop the resources for use in space heating throughout the Marmoth Lakes area. The necessary geothermal facilities and associated environmental geologic concerns will be less extensive for space heating than for electrical power generation. Depending upon the resource found and the technology employed, the supplying of cold water for the cooling towers of power plants could be one of the most serious problems associated with geothermal power production in the KGRA. Surface water of the Long Valley caldera already is highly utilized for recreation and urban water supplies, and it is questionable whether a significant amount of surface water could be diverted for use in cooling towers. Another possible water source is the groundwater supply, but its adequacy for cooling purposes has yet to be evaluated.

If geothermal development occurs, it will be necessary to acquire production data to help characterize the hydrothermal reservoir: pressure and production records, pressure-drawdown curves, transmissivity tests, and permeability and porosity data. Some hydraulic characteristics of the heat reservoir can be determined during the exploratory phase of drilling, but a full hydraulic characterization would have to await the acquisition and analysis of production data. Such information would be needed in order to assess the amount of field development that would be economically feasible. A reliable estimate of the area's exploitable geothermal reserves may involve use of some proprietary data on production provided by the field operators. 


\section{TABLE 5}

SUMMARY OF ENVIRONMENTAL GEOLOGIC ISSUES FOR MONO-LONG VALLEY KGRA, WITH A PRIORITY RANKING FOR THE ISSUES

$$
\text { ( } H=\text { high, } M=\text { medium, } L=\text { low). }
$$

Matrix indicates the phases of development for which each issue is relevant.

\section{Environmental Geologic Issues}

PHASE OF GEOTHERMAL DEVELOPMENT

Effects of development on groundwater

Effects of development on springs

Effects of development on surface water flow

Local water for cooling

Microseismicity.

Large seismic events

Fault activity

Subsidence

Horizontal ground movement

Liquefaction

Slope stability

Erosion

Volcanic hazards
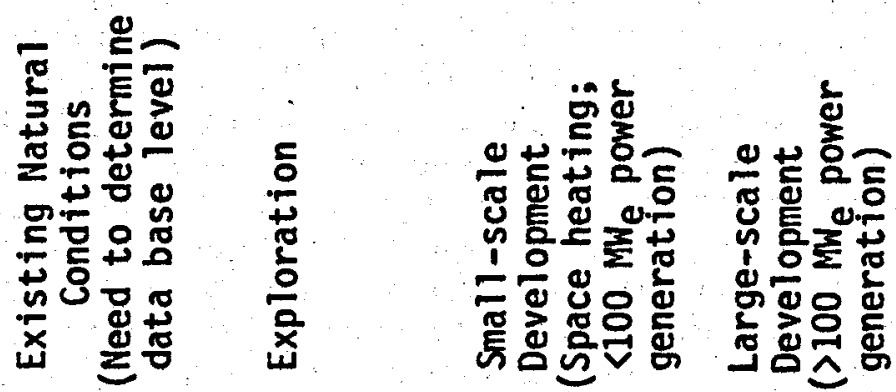

官

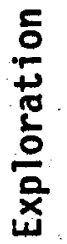

$x$

$x$

$x$

$x$

H

$x$

$x$

$x$

$x$

H

$X$

$x$

$x$

H

$x$

H

$x$

$x$

$x$

$x$

M.

$x$

$X$

$M$

$x$

$x$

$x$

$x$

$M$

$x$

$x$

M

$x$

$\begin{array}{cccc} & X & M \\ X & X & L \\ X & X & L \\ X & X & L \\ X & X & L \\ X & X & L\end{array}$


The most likely area in Mono-Long Valley KGRA for development of geothermal resources is the western part of the Long Valley caldera, around the resurgent dome. Another area of geothermal interest in the KGRA is the Mono CratersPumice Valley region, but this area's geothermal potential is relatively unknown. Geothermal development of the Mono Craters-Pumice Valley region is unlikely to commence for many years and must be preceded by extensive exploration and evaluation of resources. "The existence of either a "hot water" or "hot dry rock" geothermal system in the Mono Craters-Pumice Valley region is possible but unconfirmed at this time.

Because the Long Valley caldera was chosen by the U.S. Geological Survey as the target area for a study of "hot water" geothermal systems, enough information is available to identify the salient characteristics of the caldera's hydrothermal system. Workshop participants concluded, however, that a meaningful assessment of the area's geothermal resources must await further deep drilling. Such an assessment is needed in order to determine the course that geothermal development is likely to take: electric power generation if geothermal reserves are adequate, or space heating if reserves are 1 imited. The life expectancy of production must be great enough to enable the field development costs to be amortized. Development of resources for generation of electric power would be expected to have substantially more environmental impact than would development of resources for space heating, because of the larger scale of the field development and production facilities required.

The principal environmental geologic considerations related to geothermal development in the Mono-Long Valley KGRA are summarized in Table 5. The environmental issues with the highest priorities for consideration are those issues that deal with the hydrologic effects of geothermal development. The effects of geothermal production on springs, streams, and groundwater of the region may prove to be the most serious geologic obstacles to development of geothermal resources. Hydrologic problems may also cause friction between the field operators and other water users, notably the California Department of Fish and Game, U.S. Forest Service, LADWP, and Mamoth County Water District. Nonetheless, water-related environmental issues are primarily related to geothermal production rather than exploration and should not interfere with the exploration phase of development.

Seismic activity related to geothermal development could also be a problem in the area, expecially if the seismic activity causes changes in the plumbing of the hydrothermal reservoir. Such changes could adversely affect production levels and possibly force the abandonment of formerly productive wells and the drilling of new wells elsewhere. Increased seismic activity could-also affect the nearby built-up areas, particularly the burgeoning comunity of Mammoth Lakes.

Other potential geologic side-effects of development, such as subsidence, horizontal ground displacement, accelerated erosion, and slope instability, are not considered to be major problems but should be monitored. A modicum of planning should minimize any hazards of slope instability or liquefaction to geothermal facilities. Volcanic hazards are not expected to be affected significantly by geothermal development. Volcanic eruptions, because they are 
"acts of God" over which mankind has no control, are low-priority considerations in assessing the environmental effects of geothermal development.

As Table 5 indicates, a large body of data is needed in order to provide a data base for comparison with post-development conditions. In particular, data bases are required in order to assess the effects of development on the hydrology, seismicity, and ground displacement of the region. Table 5 also shows that environmental effects of geothermal development are most likely to be manifested during the production phase rather than during exploration.

Because the west-central Long Valley caldera is the most likely target area for geothermal development in the Mono-Long Valley KGRA, a more detailed understanding of its geothermal resources is needed. The U.S. Geological Survey investigations in the caldera have provided a broad overview of the region's geology and hydrology, as well as a preliminary evaluation of the area's geothermal potential. Further knowledge of the geothermal resources of Long Valley will have to come from deep drilling, probably by the private sector inasmuch as no further field programs are planned by the U.S. Geological Survey for the area. Because geothermal development of the Mono Craters-Pumice Valley area is many years away, initial geologic and hydrologic studies in that area should be on a reconnaissance level. The specific environmental effects of geothermal development are difficult to evaluate for the Mono Craters-Pumice Valley area until the extent of geothermal resources is delineated.

\section{ACKNOWLEDGMENTS}

The discussion of environmental issues in this chapter is based on many participants' contributions to the geology section of the Mono-Long Valley workshop which met at Manmoth Lakes on August 10-11, 1978. A list of participants who signed the geology section sign-up sheet at the workshop is included as Appendix A of this chapter. Neil B. Crow of the Lawrence Livermore Laboratory chaired the geology workshop sessions and compiled most of the notes used as an outline in discussing environmental issues of geothermal development.

Roy A. Bailey of the U.S. Geological Survey in Keston, Virginia, and Spencer $H$. Wood of Boise State University provided unpublished information and allowed the use of figures from their publications. Robert R. Curry of the University of Montana, Greg Simay of the City of Burbank, and Frank H. Olmsted of the U.S. Geological Survey in Menlo Park contributed additional unpublished information about the region.

I am grateful to the following reviewers, whose comments substantially improved the content of this chapter: Roy A. Bailey, Barry A. Boudreau and associates (U.S. Geological Survey, Menlo Park), Neil B. Crow, Paul M. Merifield (UCLA, Dept. of Earth and Space Sciences), Carl L. Strojan (UCLA, Laboratory of Nuclear Medicine and Radiation Biology), James Vantine (Union Geothermal/Union $0 i 1$ Co. of California), James F. Wickser (LADWP), and Spencer H. Wood. 


\section{REFERENCES CITED}

Allen, D. R., 1973, Subsidence, rebound and surface strain associated with oil producing operations, Long Beach, California, in Moran, D. E., Slosson, J. E., Stone, R. 0. , and Yelvertor, C. A., eds., Geology, seismicity, and environmental impact: Assoc. Eng. Geologists spec. pub.. p. 101-111.

Axtell, L. H., 1972, Mono Lake geothermal wells abandoned: California Div. Mines and Geology, California Geology, v. 25, no. 3, p. 66-67.

Bacon, C. F., Amimoto, P. Y., Sherburne, R. W., and Slosson, J. E., 1976, Engineering geology of the Geysers Geothermal Resource Area, Lake, Mendocino, and Sonoma Counties, California: California Div. Mines and Geology Spec. Rept. 122, 35 p.

Bailey, R. A., 1974, Preliminary geologic map and cross-sections of the Casa Diablo geothermal area, Long Valley caldera, Mono County, California: U.S. Geol. Survey open-file map, $1: 20,000,2$ sheets.

Bailey, R. A., Dalrymple, G. B., and Lanphere, M. A., 1976, Volcanism, structure, and geochronology of Long Valley caldera, Mono County, California: Jour. Geophys. Research, v. 81, p. 725-744.

Bailey, R. A., and Koeppen, R. P., 1977, Preliminary geologic map of Long Valley caldera, Mono County, Cal ifornia: U.S. Geol. Survey open-file report 77-468, 20p., 2 sheets, scale 1:62,500.

Bateman, $P_{0} C_{0}, 1965$, Geology and tungsten mineralization of the Bishop district, California, with a section on Gravity study of Owens Valley, by L. C. Pakiser and M. F. Kane, and a section on Seismic profile, by $L$. $C$. Pakiser: U.S. Geol. Survey Prof. Paper 470, 208 p.

Bateman, P. C., and Wahrhaftig, C., 1966, Geology of the Sierra Nevada, in Bailey, E. H., ed., Geology of northern California: California Div. Mines and Geology Bul1. 190, p. 107-172.

Blackwelder, E., 1931, Pleistocene glaciation in the Sierra Nevada and Basin Ranges: Geol. Soc. America Bull. v. 42, p. 865-922.

Bolt, B. A., and Miller, R. D., 1975, Catalogue of earthquakes in northern California and adjoining areas, 1 January $1910-31$ December 1972: Berkeley, California Univ. Seismographic Stations, 567 p.

Bonilla, M. G., 1970, Surface faulting and related effects, in Wiegel, R. L., ed., Earthquake engineering: Englewood Cliffs, N.J., PrenticeHall, p. 47-74.

California Department of Water Resources, 1964, Crustal strain and fault movement investigation: California Resources Agency, Dept. Water Resources, Bull. 116-2, 96 p., 4 map sheets.

California Department of Water Resources, 1967, Investigation of geothermal waters in the Long Valley area, Mono County: Sacramento, California Resources Agency, Dept. Water Resources, 141 p. 
California Department of Water Resources, 1973, Mammoth Basin water resources environmental study (final report): Los Angeles, California Resources Agency, Dept. Water Resources, Southern District, 166 p.

Chesterman, C. W., and Gray, C. H., Jr., 1975, Geology of the Bodie Quadrangle, Mono County, California: California Div. Mines and Geology Map Sheet 21 , scale $1: 48,000$.

Christensen, M. N., Gilbert, C. M., Lajoie, K. R., and Al-Rawi, Y., 1969, Geological-geophysical interpretation of Mono Basin, California-Nevada: Jour. Geophys. Research, v. 74, p. 5221-5239.

Curry, R. R., 1966, Glaciation about 3,000,000 years ago in the Sierra Nevada: Science, v. 154, p. 770-771.

Curry, R. R., 1968, Quaternary climatic and glacial history of the Sierra Nevada, Californià: unpublished Ph.D. dissertation, California Univ., Berkeley, 238 p.

Curry, R. R., 1971, Glacial and Pleistocene history of the Marmoth Lakes Sierra--a geologic guidebook: Montana Univ. Dept. Geology, Geol. Series Pub. No. $11,49 \mathrm{p}$.

Curry, R. R., 1974, Geothermal potential, eastern Sierra Nevada, California: a report to the East Sierra Task Force: San Francisco, Sierra Club Research, $9 \mathrm{p}$.

Dalrymple, G. B., 1963, Potassium-argon dates of some Cenozoic volcanic rocks of the Sierra Nevada, California: Geol. Soc. America Bull., v. 74, p. $379-390$.

Dalrymple, G. B., 1964, Cenozoic Chronology of the Sierra Nevada, California: California Univ. Pubs. Geol. Sci., v. 47, 41 p.

Dalrymple, G. B., Cox A., and Doell, R. R., 1965, Potassium-argon age and paleomagnetism of the Bishop Tuff: Geol. Soc. America Bull, v. 76, p. 665-674.

Evernden, J.F., and Kistler, R. W., 1970, Chronology of emplacement of Mesozoic batholithic complexes in California and western Nevada: U.S. Geol. Survey Prof. Paper 623, 42 p.

Fiske, R. S., and Tobisch, O. T., 1978, Paleographic significance of volcanic rocks of the Ritter Range pendant, central Sierra Nevada, California, in Howell, D. G., and McDougall, K. A., eds., Mesozoic paleogeography of the western United States: Pacific Sec., Soc. Econ. Paleontologists and Mineralogists, Pacific Coast paleogeography symposium 2, p. 209-221.

Friedman, M. E., Whitcomb, J. H., Allen, C. R., and Hileman, J. A., 1976, Seismicity of the southern California region, 1 January 1972 to 31 December 1974: Pasadena, Seismol. Lab., California Inst. of Technology, $142 \mathrm{p}$. 
Gilbert, C. M., 1938, Welded tuff in eastern California: Geol. Soc. America Bul1., v. 49 , p. 1829-1862.

Gilbert, C. M., Christensen, M. N., Al-Rawi, Y., and Lajoie, K. R., 1968, Structural and volcanic history of Mono Basin, California-Nevada, in Coats, R. R., Hay, R. L., and Anderson, C. A., eds., Studies in volcanology: Geol. Soc. America Mem. 116, p. 275-329.

Green, J. P., 1973, An approach to analzing multiple causes of subsidence, in Moran, D. E., Slosson, J. E., Stone, R. O., and Yelverton, C. A., eds., Geology, seismicity, and environmental impact: Assoc. Eng. Geologists spec. pub., p. 79-87.

Gresswell, W. K., 1940, Short report on the geological formations encountered in driving the Mono Craters tunnel: California Jour. Mines and Geology, v. 36 , no. 2, p. 199-204.

Healy, J. H., Rubey, W. W., Griggs, D. T., and Raleigh, C. B., 1968, The Denver earthquakes: Science, v. 161, p. 1301-1310.

Hileman, J. A., Allen, C. R., and Nordquist, J. M., 1973, Seismicity of the southern California region, 1 January 1932 to 31 December 1972: Pasadena, Seismol. Lab., California Inst. of Technology, $487 \mathrm{p}$.

Hill, D. P., 1976, Structure of Long Valley caldera, California, from a seismic refraction experiment: Jour. Geophys. Research, v. 81 , p. 745-753.

Housner, G. V., 1970, Strong ground motion, in Weigel, R. L., ed., Earthquake engineering: Englewood Cliffs, N.J., Prentice-Ha11, p. 75-91.

Huber, N. K., and Rinehart, C. D., 1965, Geologic map of the Devils Postpile quadrangle, Sierra Nevada, California: U.S. Geol. Survey Geol. Quad. Map GQ-437, scale $1: 62,500$.

Huber, N. K., and Rinehart, C. D., 1967, Cenozoic volcanic rocks of the Devils Postpile quadrangle, eastern Sierra Nevada, California: U.S. Geol. Survey Prof. Paper 554-D, 21 p.

Kane, M. F., Mabey, D. R., and Brace, R.-L., 1976, A gravity and magnetic investigation of the Long Valley caldera, Mono County, California: Jour. Geophys. Research, v. 81, p. 754-762.

Kistler, R. W., 1966a, Geologic map of the Mono Craters quadrangle, Mono and Tuol umne Counties, California: U.S. Geol. Survey Geol. Quad. Map GQ-462, scale $1: 62,500$.

Kistler, R. W., 1966b, Structure and metamorphism in the Mono Craters quadrangle, Sierra Nevada, California: U.S. Geol. Survey Bull. 1221-E, 53 p.

Kistler, R. W., Bateman, P. C., and Brannock, W. W., 1965, Isotopic ages of minerals from granitic rocks of the central Sierra Nevada and Inyo Mountains, California: Geol. Soc. America Bull., v. 76, p. 155-164. 
Koenig, J. B., 1963, Walker Lake sheet, Geologic map of California, 01 af P. Jenkins edition: California Div. Mines and Geology, scale 1:250,000.

Krauskopf, K. B., and Bateman, P. C., 1977, Geologic map of the Glass Mountain quadrangle, Mono County, California, and Mineral County, Nevada: U.S. Geol. Survey Geol. Quad. Map GQ-1099, scale 1:62,500.

Kubota, K., and Aosaki, K., 1975, Reinjection of geothermal hot water at the Otake geothermal field, in Lawrence Berkeley Lab., Proceedings, second United Nations conference on the development and use of geothermal resources: Washington, D.C., U.S. Govt. Printing Office, v. 2, p. 1379-1383.

Lachenbruch, A. H., Sass, J. H., Munroe, R. J., and Moses, T. H., Jr., 1976a, Geothermal setting and simple heat conduction models for the Long Valley caldera: Jour. Geophys. Research, v. 81, p. 769-784.

Lachenbruch, A. H., Sorey, M. L., Lewis, R. E., and Sass, J. H., 1976b, The near-surface hydrothermal regime of Long Valley caldera: Jour. Geophys, Research, v. 81, p. 763-768.

Lee, K., 1969, Infrared exploration for shoreline springs - a contribution to the hydrogeology of Mono Basin, California: unpublished Ph.D. dissertation, Stanford Univ., 196 p.

Lewis, R. E., 1974, Data on wells, springs, and thermal springs in Long Valley, Mono County, California: U.S. Geol. Survey open-file report, 52 p.

Lipshie, S. R., 1974, Surficial and engineering geology of the Mammoth Creek area, Mono County, California: unpublished M.S. thesis, California Univ., Los Angeles, 163 p.

Loeffler, R. M., 1977, Geology and hydrology, in Winkler, D. W., ed., An ecological study of Mono Lake, California: California Univ., Davis, Inst. Ecology Pub. No. 12, p. 6-38.

Mariner, R. H., and Willey, L. M., 2976, Geochemistry of thermal waters in Long Valley, Mono County, California: Jour. Geophys. Research, v. 81, p. $792-800$.

Mayo, E. B., 1934, The Pleistocene Long Valley Lake in eastern California: Science, new ser., v. 80, no. 2065, p. 95-96.

McNitt, J. R., 1963, Exploration and development of geothermal power in California: California Div. Mines and Geology Spec. Rept. 75, 45 p.

Nichols, D. R., and Buchanan-Banks, J. M., 1974, Seismic hazards and land-use planning: U.S. Geol. Survey Circ. 690,33 p.

Oakeshott, G. B., Greensfelder, R. W., and Kahle, J. E., 1972,...one hundred years later: California Div. Mines and Geology, California Geology, v. 25 , no. 3 , p. $55-61$. 
Pakiser, L. C., 1961, Gravity, volcanism, and crustal deformation in Long Valley, California: U.S. Geol. Survey Prof. Paper 424-B, p. B250-B253.

Pakiser, L. C., 1968, Seismic evidence for the thickness of Cenozoic deposits in Mono Basin, California: Geol. Soe, America Bull., v. 79, p. 1833-1838.

Pakiser, L. C., 1976, Seismic exploration of Mono Basin, California: Jour. Geophys. Research, v. 81, p. 3607-3618.

Pakiser, L. C., Press, F., and Kane, M. F., 1960, Geophysical investigation of Mono Basin, California: Geol. Soc. America Bull., v. 71, p. 415-448.

Pitt, A. M., and Steeples, D. W., 1975, Microearthquakes in the Mono Lakenorthern Owens Valley region from September 28 to October 18, 1970: Seismol. Soc. America Bull., v. 65, p. 835-844.

Putnam, W. C., 1949, Quaternary geology of the June Lake district, California: Geol. Soc. America Bull., v. 60, p. 1281-1302.

Putnam, W. C., 1960, Origin of Rock Creek and Owens River Gorges, Mono County, California: California Univ. Pubs. Geol. Sci., v. 34, no. 5, p. 221-280.

Putnam, W. C., 1962, Late Cenozoic geology of McGee Mountain, Mono County, California: California Univ. Pubs. Geol. Sci., v. 40, no. 3, p. 181-218.

Raleigh, C. B., Healy, J. H., and Bredehoeft, J.D., 1972, Faulting and crustal stress at Rangely, Colorado, in Heard, H. C., Borg, I. Y., Carter, N. L., and Raleigh, C. B., eds., FTow and fracture of rocks: Am. Geophys. Union, Geophys. Mon. 16, p. 275-284.

Ramos, G., 1978, Quake hits San Joaquin Valley, Sierra Nevada: Los Angeles Times (0ct. 5, 1978), v. 97, pt. 1, p. 3.

Richter, C. F., 1958, Elementary seismology: San Francisco, W. H. Freeman, $768 \mathrm{p}$.

Ridley, A. P., and Taylor, C. L., 1975, Earthquake-related geologic and seismic safety of geothermal developments, in Lawrence Berkeley Lab., Proceedings, second United Nations conference on the development and use of geothermal resources: Washington, D.C., U.S. Govt. Printing Office, v. 2, p. 1411-1415.

Rinehart, C. D., and Ross, D. C., 1957, Geology of the Casa Diablo Mountain quadrangle, California: U.S. Geol. Survey Geol. Quad. Map GQ-99, scale $1: 62,500$.

Rinehart, C. D., and Ross, D. C., 1964, Geology and mineral deposits of the Mount Morrison quadrangle, Sierra Nevada, Cal ifornia, with a section on A gravity study of Long Valley, by L. C. Pakiser: U.S. Geol. Survey Prof. Paper 385, 106 p. 
Rinehart, C. D., Ross, D. C., and Huber, N. K., 1959, Paleozoic and Mesozoic fossils in a thick stratigraphic section in the eastern Sierra Nevada, California: Geol. Soc. America Bull., v. 70, p. 941-945.

Russe11, I. C., 1889, Quaternary history of Mono Valley, California: U.S. Geol. Survey 8th Ann. Rept., pt. 1, 261-394.

Seed, H. B., and Idriss, I. M., 1971, Simplified procedure for evaluating soil liquefaction potential: Am. Soc. Civil Engineers Proc., Jour. Soil Mechanics and Found. Div., v. 97, no. SM9, p. 1249-1273.

Sharp, R. P., 1972, Geology field guide to Southern California: Dubuque, Iowa, Kendall/Hunt Publishing Co., $181 \mathrm{p}$.

Sharp, R. P., and Birman, J. H., 1963, Additions to classical sequence of Pleistocene glaciations, Sierra Nevada, California: Geol. Soc. America Bull., v. 74, p. 1079-1086.

Smith, E. I., 1973, Mono Craters, California: a new interpretation of the eruptive sequence: Geol. Soc. America Bull. v. 84, p. 2685-2690.

Smith, G. I., 1976, Origin of lithium and other components in the Searles Lake evaporites, California, in Vine, J. D., ed., Lithium resources and requirements by the year 2000: U.S. Geol. Survey Prof. Paper 1005, p. 92-103.

Smith, G. S., ed., 1976, Mammoth Lakes Sierra: a handbook for roadside and trail, 4th ed.: Palo Alto, Genny Smith Books, 147 p.

Smith, J. L., and Rex, R. W., 1977, Drilling results from the eastern Long Valley caldera, in American Nuclear Society, Energy and mineral resource recovery: U.S. Dept. of Energy CONF-770440, p. 529-540.

Sorey, M. L., 1976, Potential effects of geothermal development on springs at the Hot Creek Fish Hatchery in Long Valley, Mono County; California: U.S. Geol. Survey open-file report $75-637,13 \mathrm{p}$.

Sorey, M. L., and Lewis, R. E., 1976, Convective heat flow from hot springs in the Long Valley caldera, Mono County, California: Jour. Geophys. Research, v. 81, p. 785-791.

Sorey, M. L., Lewis, R. E., and 01msted, F. H., 1978, The hydrothermal system of Long Valley caldera, California: U.S. Geol. Survey Prof. Paper 1044-A, 60 p.

Steeples, D. W., and Iyer, H. M., 1976, Low-velocity zone under Long Valley as determined from teleseismic events: Jour. Geophys. Research, v. 81, p. 849-860.

Steeples, D. W., and Pitt, A. M., 1973, Microearthquakes in and near Long Valley, California (abstract): EOS, Trans. Amer. Geophys. Union, v. 54, p. 1213. 
Steeples, D. W., and Pitt, A. M., 1976, Microearthquakes in and near Long Valley, California: Jour. Geophys. Research, v. 81, p. 841-847.

Stilwell, W. B., Hall, H. K., and Tawhai, J., 1975, Ground movement in New Zealand geothermal fields, in Lawrence Berkeley Lab., Proceedings, second United Nations conference on the development and use of geothermal resources: Washington, D.C., U.S. Govt. Printing Office, v. 2, p. $1427-1434$.

Strand, R. G., 1967, Mariposa sheet, Geologic map of California, 0laf P. Jenkins edition: California Div. Mines and Geology, scale 1:250,000.

U.S. Forest Service, 1972, Forest visitors map, Inyo National Forest: planimetric map, scale $1: 126,720,1$ sheet.

White, D. E., and Williams, D. L., eds., 1975, Assessment of geothermal resources of the United States--1975: U.S. Geol. Survey Circ. 726, $155 \mathrm{p}$.

Wood, S. H., 1977a, Distribution, correlation, and radiocarbon dating of late Holocene tephra, Mono and Inyo craters, eastern California: Geol. Soc. Anerica Bull., v. 88, p. 89-95.

Wood, S. H., 1977b, Chronology of late Pleistocene and Holocene volcanics, Long Valley and Mono Basin geothermal areas, eastern California: unpublished U.S. Geol. Survey tech. report (contract no. 14-08-000115166), 76 p.

Wood, S. H., 1977c, Mono Craters, California: history of rhyolite volcanism. (abstract): Geol. Soc. America, Abstracts with Programs (Cordilleran Sec.), v. 9, no. 4, p. 528-529.

Youd, T. L., 1971, Landsliding in the vicinity of the Van Norman Lakes, in U.S. Geological Survey and National Oceanic and Atmospheric Administration, The San Fernando, California, earthquake of February 9, 1971: U.S. Geol. Survey Prof. Paper 733, p. 105-109. 
APPENDIX A: List of Geology Workshop Participants

This list is taken from the stgn-up sheet for the geology session of the Mono-Long Valley workshop held at Mammoth Lakes on August 10-11, 1978. Only the names and affiltations of participants are given in this appendix; complete mailing addresses are given in Appendix I to the environmental overview report.

Roy A. Bailey

U.S. Geological Survey

Robert Butler

Chevron Resources Co.

Dean Cornett

Lawrence Livermore Laboratory

Neil B. Crow

Lawrence Livermore Laboratory

Robert A. Dinsmore

Inyo County Planning Cormission

Dale Kite

U.S. Forest Service

Diori Kreske

Naval Weapons Center, China Lake

Steve Lipshie

University of California, Los Angeles

Roger C. Martin

California Division of Mines and Geology

John Mawby

Deep Springs College

Paul M. Merifield

University of California, Los Angeles

Leroy M. Mohorich

U.S. Geological Survey

Frank H. Olmsted

U.S. Geological Survey

Charles Priddy

California State Lands Comission

Walter Randall

Geothermal Resources International, Inc.

Bill Taylor

U.S. Forest Service 
APPENDIX B: Glossary of Geologic Terms

alluvial deposits: See alluvium

alluvium; Recent deposits of stream or fan sediments, generally unconsolidated.

andesite: Fine-grained volcanic rock which contains no quartz and which has plagioclase feldspar that is more sodic than that found in basalt.

aquifer: Body of water-bearing soil or rock which is sufficiently porous and permeable to yield economically significant quantities of groundwater.

aseismic: Not subject to earthquake activity.

ash flow: A turbulent mixture of unsorted, gas-charged voicanic ash and lapilli ejected explosively from a vent or fissure. Ash flows may lithify to form tuff $(q \cdot v$.

basalt: Fine-grained, dark volcanic rock which contains no quartz and which has plagioclase feldspar that is more calcic than that found in andesite.

basement rocks: A complex of igneous and metamorphic rocks that underlies younger stratified rocks in an area.

batholith: A large intrusive mass of granitic (q.v.) rocks that has a surface outcrop area greater than $40 \mathrm{sq} \mathrm{mi}(100 \mathrm{sq} \mathrm{km})$. Bathol tth rocks, which are emplaced at depth as magma (q.v.), generally are discordant with adjacent stratified rock units.

blowout: The sudden and uncontrolled escape of pressurized fluids from a well.

breccia: A rock composed of coarse, angular fragments of other rocks or minerals; fragments are pebble-size or larger.

calcareous tufa: A chemical sedimentary rock composed of calcium carbonate, formed by evaporation or precipitation around springs or in streams or lakes.

caldera: A large, basin-shaped volcanic depression, formed by the removal of the underlying volume of rock by volcanic processes.

chert: A compact, siliceous rock formed of cryptocrystalline (microscopic crystals) silica. It can have either an organic or a chemical (precipitate) origin.

conglomerate: A well-cemented rock containing rounded fragments of other rocks or minerals; fragments are pebble-sized or larger. Compare with breccia, above.

creep: See fault creep. 
dacite: Volcanic equivalent of granodiorite (q.v.); may contain crystals of quartz, feldspar, and various dark minerals (pyroxene, hornblende, biotite). Dacite may have either a glassy or a fine-grained groundmass.

dome: Any roughly circular structure having an upward surface that is convex upward. Volcanic domes are steep-sided protrusions of bulbous masses of originally viscous lava over and around a volcanic vent.

drawdown: The difference between the height of the water table and that of the water in a well, resulting from withdrawal of water by pumping.

epicenter: That point on the Earth's surface which is directly above an earthquake's focus, the point at which the seismic waves originate.

escarpment: A high, steep, abrupt face of rock.

extrusion: The emission of lava at the Earth's surface.

fault: Fracture along which there has been displacement of the two sides relative to one another, with direction of movement being parallel to the fracture plane.

fault creep: Continuous but slow deformation along a fault zone, involving movement with no associated seismic activity.

fill: Any sedimentary or volcanic material deposited so as to fill or partly fill a valley or other depression, generally in basement rocks $(q . v$.

fissure: Open fracture in rock, due to separation at right angles to fracture plane.

fumarole: A hole or vent from which volcanic fumes or vapors are emitted; a steam vent.

geodetic survey: A survey involving the precise location of points on the Earth's surface, usually over large areas of land.

geothermometer: A mineral or mineral assemblage whose properties or presence indicate a limit or range for the temperature of formation of the host rock.

glacial deposits: See till.

glacial outwash: Stratified debris carried from a glacier by meltwater streams and deposited beyond the margin of the glacier.

glaciation: Any of several relatively short-lived episodes of geologic time during which glaciers were more extensive than at present.

granitic: Pertaining to the granite family of plutonic (intrusive igneous) rocks, medium- to coarse-grained rocks composed primarily of quartz and feldspar minerals. 
granodiorite: Granitic rock in which plagioclase is the dominant feldspar, with subordinate amounts of potassium feldspar also present.

hydrothermal: Pertaining to heated water or the effects of heated water.

hydrothermal alteration: Changes in rocks brought about by the addition or removal of material through hot fluids, particularly water, associated with heated magma bodies.

hydrothermal reservoir: A body of porous and permeable rock that contains economically significant quantities of hot water.

intensity: A measure of the effects of an earthquake at a particular place on humans and structures. Intensity depends both on earthquake magnitude $\left(q \cdot v_{.}\right)$and on distance from the epicenter $\left(q_{\cdot} v_{\bullet}\right)$.

intermediate: Pertaining to igneous rocks that are transitional in composition between basaltic (low-silica) and rhyolitic (high-silica) rocks; intermediate rocks generally have a silica content between 54 and 65 percent.

intermittent stream: A stream that flows only at certain times of the year, depending on the availability of its source water (groundwater or surface runoff).

intrusion: Body of igneous rock that invades older rocks. The invading body is emplaced as a plastic or liquid mass.

lacustrine: Pertaining to or formed in lakes.

lapilli: Pebble-sized rock debris produced by explosive volcanic eruptions; Tapilli (singular is "lapillus") are between 4 and $64 \mathrm{~mm}$ in diameter. Material less than $4 \mathrm{~mm}$ in diameter is called "volcanic ash."

limestone: Sedimentary rock, generally of biological or chemical origin, which is composed primarily of calcium carbonate (calcite).

liquefaction: The sudden loss of soil strength owing to collapse of the soil structure by cyclic loading, as during an earthquake, and a sudden but temporary rise in pore pressure in the soil.

lithology: The physical characteristics (e.g., color, structure, mineralogic composition, grain size) of rocks.

magma: Naturally occurring molten or partially molten rock below the Earth's surface. Most igneous rocks are believed to be derived from magma by cooling and solidification.

magnitude: A measure of the strain energy released by an earthquake, as determined from seismograph records. Magnitudes are usually reported in terms of the Richter scale, which is based on the logarithm of the amplitude of the deflection observed on a seismograph located $100 \mathrm{~km}$ from the epicenter. 
metamorphic rocks: Rocks which have been altered from their original form by the effects of pressure, temperature, and chemical changes below the zone of weathering and cementation.

metasediments: Metamiorphosed sedimentary rocks.

metavolcanics: Metamorphosed volcanic rocks.

microseismicity: Weak, more or less continuously occurring seismic activity that can only be detected by sensitive instruments. Microseismicity is seismic noise unrelated to earthquake events.

moraine: Hill or ridge of glacial debris, constructed by the direct action of glacier ice and independent of the underlying topographic surface.

obsidian: Volcanic glass, usually black in color and having a rhyolitic composition. (Also see rhyolite.)

pendant: Remnant of older rocks, usually metamorphosed, that formed the roof of an intrusive igneous body. The pendant (also called "roof pendant") is an inclusion of older rocks within the intruding mass.

perennial stream: A stream that flows throughout the year.

phreatic explosion: Volcanic explosion or eruption of steam, water, or mud. It is caused by the heating of groundwater by underlying hot rocks or magma; the hot water migrates upward, flashes to steam, and causes an explosion because of the increased fluid pressure.

pluton: A body of igneous rock emplaced in a molten or semi-molten state at considerable depth. Plutons generally are composed of granitic $(q \cdot v \cdot)$ rocks.

pumice: Light colored volcanic froth, generally of rhyolitic composition. (Also see rhyolite.)

quartz monzonite: A granitic (q.v.) rock in which plagioclase and potassium feldspar are roughly equally abundant. (Compare with granodiorite.)

radiocarbon dating: A technique of radiometric dating ( $q . v$.$) of organic$ material by measuring the concentration of carbon-14, a radioactive isotope, remaining in the material. Carbon-14 has a half-life of about 5570 years, and the technique can be applied to material up to about 70,000 years old.

radiometric dating: Determining the age of geologic materials by measuring the concentration of a short-life radioactive element or else a long-life radioactive element plus its decay products. Age can be calculated from the measured concentration, using the disintegration rate (half-life) of the radioactive element.

resurgent dome: Structural dome, within a caldera (q.v.), that has been uplifted, probably by replenishment of the underlying magma chamber, following subsidence of the caldera. 
rhyodacite: Volcanic equivalent of quartz monzonite (q.v.); may contain crystals of quartz, feldspar, hornblende, or biotite. Rhyodacite may also include glassy material. Rhyodacite and guartz latite are indistinguishable in hand specimens but differ chemically, quartz latite being more alkaltc than is rhyodacite. In the Long Valley-Mammoth Lakes region, rocks described as "rhyodacite" are technically quartz latite despite the absence of quartz as a constituent mineral.

rhyolite: Volcanic equivalent of granite; composed of silica, feldspar, biotite, and/or hornblende, as well as volcanic glass. May contain crystals of these minerals. Has fewer dark minerals and has less calcic feldspar than does rhyodacite (q.v.)

ring fracture: A steep-sided fault pattern that is cylindrical in outline and that is associated with caldera (q.v.) subsidence.

riparian: Pertaining to the banks of a body of water, especially a watercourse such as a stream. "Riparian water rights" are water rights held by virtue of owning property along a given watercourse.

scarp: A relatively steep and straight, cliff-like face produced by faulting or, less commonly, by erosion.

sedimentation: The process of accumulating sedementary deposits in layers, principally by mechanical means.

seismicity: Pertaining to earthquake activity, particularly the relative frequency of occurrence and magnitude $(q \cdot v \cdot)$ of earthquakes.

serpentinite: A rock consisting mostly of serpentine minerals formed by alteration of low-silica igneous rocks.

shale: A fine-grained sedimentary rock formed by the compaction and consolidation (conversion of loose sediment into rock) of clay-rich mud. Shale generally is relatively soft and thinly layered parallel to the bedding plane.

silica: Silicon dioxide. Silica, which is resistant to weathering, occurs naturally in its pure form as quartz, chert (q.v.), flint, opal, and several other minerals.

siliceous sinter: White, opaline form of silica (q.v.) produced by chemical precipitation around hot springs or geysers. Sinter differs from chert (q.v.) in being lightweight and porous, whereas chert is dense.

siltstone: Fine-grained sedimentary rock composed of particles intermediate in size between those of shale (q.v.) and sandstone.

stratigraphic: Pertaining to the characteristics, thickness, sequence, age, and interrelationships of geologic units.

substrate: The underlying soil and rock materials that serve as a foundation, as for structures or vegetation. 
tectonic: Pertaining to processes of deformation of the Earth's crust and to geologic structures resulting from these processes.

tephra: A general term for fragmental rock material formed by explosive volcanic eruptions. (Also see lapilli.)

thermal spring: A spring having water that is appreciably warmer than the Tocal mean annual air temperature. Thermal springs include hot and warm springs.

till: Poorly-sorted (well-graded), unstratified sediment and rocky debris carried or deposited by glaciers.

transmissivity: In an aquifer $\left(q . v_{.}\right)$, the rate at which water is transmitted through a unit width under specified conditions.

tufa: See calcareous tufa.

tuff: A rock formed of small, usually compacted, volcanic fragments, such as pumiceous volcanic ash and lapilli $\left(q \cdot v_{\bullet}\right)$. (Also see welded tuff.)

tuff breccia: A tuff $\left(q \cdot v_{0}\right)$ which contains abundant large (pebble-sized or bigger), angular blocks of assorted rock fragments. (Also see breccia.)

unconformable: Not in uninterrupted depositional succession with the older underlying rocks, as a result of a substantial gap (erosion or nondeposition) in the geologic record.

volcanic dome: See dome.

volcano-tectonic depression: A large depression, generally trough-shaped, formed by a combination of volcanic and tectonic $\left(q_{\cdot} v_{\bullet}\right)$ processes. Most large-scale calderas $\left(q \cdot v_{.}\right)$are volcano-tectonic depressions.

void ratio: "The ratio of pore space volume to volume of solids in a rock or soil.

welded tuff: Particularly dense, hard tuff $\left(q \cdot v_{.}\right)$that was emplaced and hardened into rock while still in a hot, plastic state, causing its glassy particles to become flattened.

wildcat: An exploratory well drilled without sufficient geologic information or in an unproven territory. 


\section{APPENDIX C: Supplemental List of References}

(not cited in the report)

Benioff, H., and Gutenberg, B., 1939, The Mammoth "Earthquake Fault" and related features in Mono County, California: Seismol. Soc. America Bull., v. 29, p. 333-340.

Birman, J. H., 1964, Glacial geology across the crest of the Sierra Nevada, California: Geol. Soc. America Spec. Paper 75, $80 \mathrm{p}$.

Blackwelder, E., 1929, Moraines of Convict Lake glaciers (abstract): Geol. Soc. America Bull., v. 40, p. 171.

Chelikowsky, J. R., 1940, Tectonics of the rhyolite in the Mammoth embayment, California: Jour. Geology, v. 48, p. 421-435.

Christensen, M. N., 1966, Late Cenozoic crustal movements in the Sierra Nevada of California: Geol. Soc. America Bull., v. 77, p. 163-182.

Cleveland, G. B., 1961, Economic geology of the Long Valley diatomaceous earth deposit, Mono County, California: California Div. Mines and Geology Map Sheet 1, scale 1:31,250.

Cleveland, G. B., 1962, Geology of the Little Antelope Valley clay deposits, Mono County, California: California Div. Hines and Geology Spec. Rept. 72,28 p.

Dalrymple, G. B., 1967, Potassium-argon ages of Recent rhyolites of the Mono and Inyo Craters, California: Earth and Planet, Sci. Letters, v. 3, p. 289-298.

Dunn, J. R., 1953, The origin of the deposits of tufa at Mono Lake: Jour. Sed. Petrology, v. 23, p. 18-23.

Friedman, I., 1968, Hydration rind dates rhyolite flows: Science, $v$. 159 , p. $878-880$.

Gilbert, C. M., 1941, Late Tertiary geology southeast of Mono Lake, California: Geo1. Soc. America Bull., v. 52, p. 781-816.

Hamilton, W., 1978, Mesozoic tectonics of the western United States, in Howe 11, D. G., and MCDouga 11, K. A., eds., Mesozoic paleogeography of the western United States: Pacific Sec., Soc. Econ. Paleontologists and Mineralogists, Pacific Coast paleogeography symposium 2, p. 33-70.

Hildreth, W., 1976, The Bishop Tuff: compositional zonation in a silicic magma chamber without crystal settling (abstract): Geol. Soc. America Abstracts with Programs (Ann. Mtg.) v. 8, no. 6, p. 918.

Izett, G. A., Wilcox, R. E., Powers, H. A., and Desborough, G. A., 1970, The Bishop ash bed, a Pleistocene marker bed in the western United States: Quaternary Research, v. 1, p. 121-132. 
Jack, R. N., and Carmichael, I. S. E., 1969, The chemical 'fingerprinting' of acid volcanic rocks: California Div. Mines and Geology Spec. Rept. 100, p. 17-32.

LeConte, J., 1879, On the extinct volcanoes about Lake Mono, and their relation to the glacial drift: Am. Jour. Sci., 3d ser., v. 18, p. 35-44.

Lipshie, S. R., 1976, Geologic guidebook to the Long Valley - Mono Craters region of eastern California: Geol. Soc. UCLA Field Guide No. 5, 184 . p.

Loney, R. A., 1968, Flow structure and composition of the Southern Coulee, Mono Craters, California - a pumiceous rhyolite flow, in Coats, R. R., Hay, R. L., and Anderson, C. A., eds., Studies in volcanology: Geol. Soc. America Mem. 116, p. 415-440.

Manmoth/UCLA Project, 1972, Facing the future: five alternatives for Mamnoth Lakes: Los Angeles, UCLA School of Architecture and Urban Planning, 243 p.

Merriam, R., and Bischoff, J. L., 1975, Bishop ash: A widespread volcanic ash extended to southern Cal ifornia: Jour. Sed. Petrology, v. 45, p. 207-211.

Nadeau, R. A., 1974, The water seekers, 2nd ed.: Salt Lake City, Peregrine Smith, 278 p.

Noble, D. C., and Slemmons, D. B., 1975, Timing of Miocene faulting and intermediate volcanism in the central Sierra Nevada and adjacent Great Basin: California Div. Mines and Geology, California Geology, v. 28, p. 105.

Pakiser, L. C., Kane, M. F., and Jackson, W. H., 1964, Structural geology and volcanism of Owens Valley region, California - a geophysical study: U.S. Geol. Survey Prof. Paper 438, 68 p.

Putnam, W. C., 1938, The Mono Craters, California: Geog. Rev., v. 28, p. 68-82.

Putnam, W. C., 1950, Moraine and shoreline relationships at Mono Lake, California: Geol. Soc. America Bull., v. 61, p. 115-122.

Quick, G. L., 1974, Geotechnical reconnaissance, Mammoth Lakes area, Mono County, California, for Mr. John L. Nordmark, A.I.P.: Ventura, Calif., Geotechnical Consultants, Inc., unpub. rept., $34 \mathrm{p}$.

Rinehart, C. D., and Huber, N. K., 1965, The Inyo Crater Lakes - a blast in the past: California Div. Mines and Geology, Mineral Information Service, v. 18, no. 9, p. 169-172.

Sampson, R. J., and Tucker, W. B., 1940, Mineral resources of Mono County: California Jour. Mines and Geology, v. 36, no. 2, p. 116-156. 
Scholl, D. W., and Taft, H. H., 1964, Algae, contributors to the formation of calcareous tufa, Mono Lake, California: Jour. Sed. Petrology, v. 34, p. 309-319.

Schol1, D. W., von Huene, R., St.-Amand, P., and Ridion, J. B., 1967, Age and origin of topography beneath Mono Lake, remnant Pleistocene lake, California: Geol. Soc. America Bull., v. 78, p. 583-599.

Sharp, R. P., 1968, Sherwin till - Bishop Tuff geological relationships, Sierra Nevada, California: Geol. Soc. America Bull., v. 79, p. 351-364.

Sharp, R. P., 1969, Semiquantitative differentiation of glacial moraines near Convict Lake, Sierra Nevada, California: Jour. Geology, v. 77, p. 68-91.

Sheridan, M. F., 1971, Guidebook to the Quaternary geology of the east-central Sierra Nevada: XVI Field Conf., Rocky Mtn. Sec., Friends of the Pleistocene, $60 \mathrm{p}$.

Silberman, M. L., Fabbi, B. P., and Chesterman, C. W., 1972, K-Ar age ranges and $\mathrm{K}, \mathrm{Rb}$, and $\mathrm{Sr}$ contents of Pliocene volcanic rocks, southern Bodie Hills, Mono County, Cal ifornia (abstract): Geol Soc. America, Abstracts with Programs (Cordilleran Sec.), v. 4, no. 3, p. 236-237.

Silberman, M. L., and McKee, E. H., 1974, Ages of Tertiary volcanic rocks and hydrothermal precious-metal deposits in central and western Nevada, in Guidebook to the geology of four Tertiary volcanic centers in central Nevada: Nevada Bur. Mines and Geology Report 19, p. 67-72.

Slemmons, D. B., 1966, Cenozoic volcanism of the central Sierra Nevada, California, in Bailey, E. H., ed., Geology of northern California: California Div. Mines and Geology Bu11. 190, p. 199-208.

Smith, R. L., and Bailey, R. A., 1968, Resurgent cauldrons, in Coats, R. R., Hay, R. L., and Anderson, C. A., eds., Studies in volcanology: Geol. Soc. America Mem. 116, p. 613-662.

Twain, M., 1965, Islands of Mono Lake (extract from Roughing It, published in 1872): California Div. Mines and Geology, Mineral Information Service, v. 18 , no. 9, p. $173-180$.

White, D. E., and Williams, D. L., eds., 1975, Assessment of geothermal resources of the United States - 1975: U.S. Geol. Survey Circ. 726, 155 p.

Whitehead, H. C., and Feth, J. H., 1961, Recent chemical analyses of waters from several closed-basin lakes and their tributaries in the western United States: Geol. Soc. America Bull., v. 72, p. 1421-1426.

Whitney, J. D., 1865, Geological Survey of California, Report of progress and synopsis of the field work from 1860 to 1864: California Geol. Survey, Geology, v. 1, $498 \mathrm{p}$. 

Chapter 4

数

\section{WATER QUALITY OVERVIEW}

R. Ted Abresch ${ }^{1}$ and $A 1 i$ Ghorbanzadeh 2

1Department of Land, Air and Water Resources

2Department of Civil Engineering

University of California, Davis 


\section{TABLE OF CONTENTS}

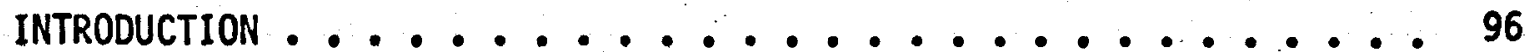

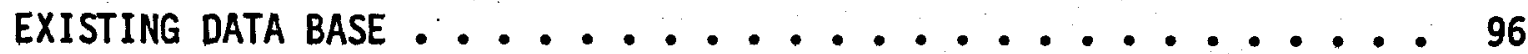

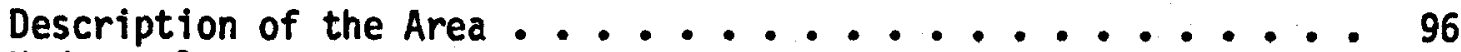

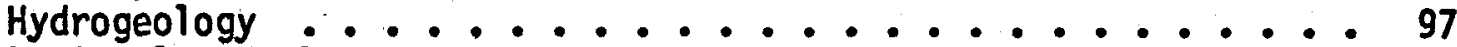

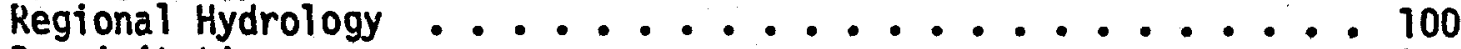

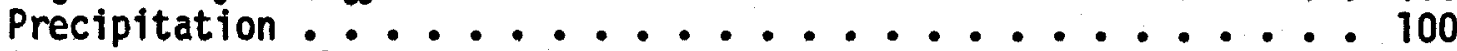

Surface Water Flows ............... 100

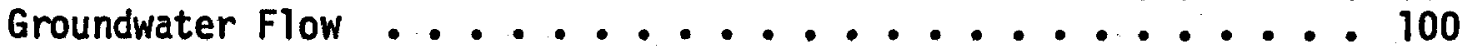

Hydrogeology of the Hot Springs ................. 105

Fluctuations in Spring Discharge ................ 107

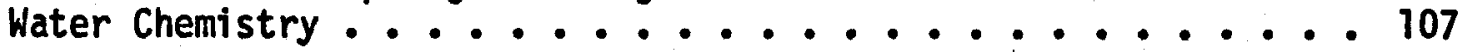

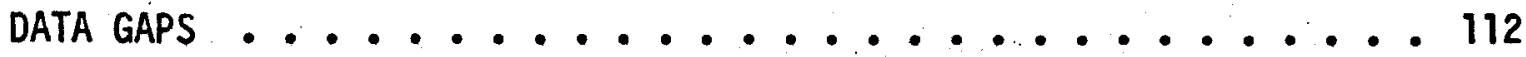

Hydrology ................... 112

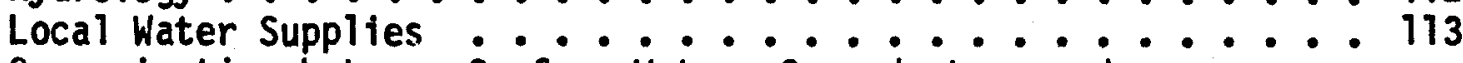

Communication between Surface Water, Groundwater, and

Geothermal Water ................ 113

Water Chemistry ................. 115

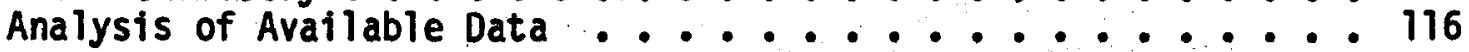

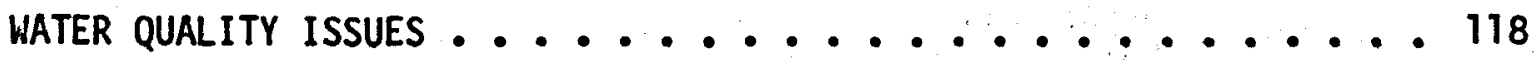

POTENTIAL BARRIERS TO GEOTHERMAL ENERGY DEVELOPMENT . . . . 121

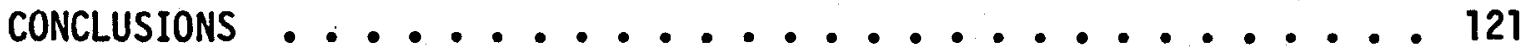

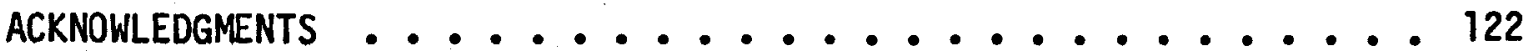

REFERENCES CITED ...................... 123

APPENDIX A: DATA SOURCES ................... 125 
1. Laboratory Data for Selected Cores from Test Holes in Long

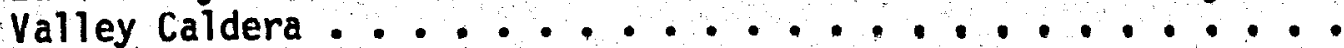

2. Water Budget for the Long Valley Drainage Basin for Water Years 1964-1974 .................... 101

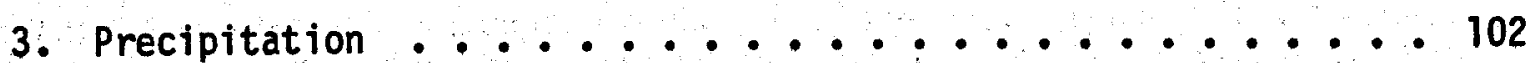

4. Lake Crowley Hydrologic Balance ............. 103

5. Water Quality Data on Selected Streams Entering the Crowley Lake-Owens River System ............... 108

6. Selected Chemical Constituents, Temperature, and Isotopic Compositions for Thermal and Non-Thermal Waters in Long Valley ............................. 110

7. Sumary of Data Gaps ....................... 117

8. Major Water Quality Issues .............. 119

LIST OF FIGURES

1. Map of Long Valley Caldera Showing Relations among Groundwater Flow, Hot Spring Discharge, 10-m Temperatures, and the

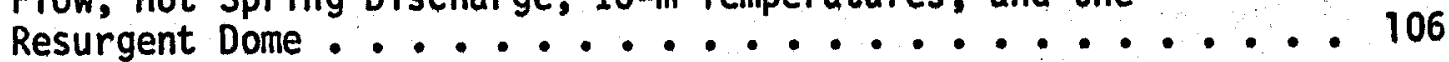

2. Occurrence of Trace Elements in Selected Surface Waters .... 111

3. Block Diagram of a Hot Spring ............. 114 


\section{INTRODUCTION}

The principal object of this chapter is to evaluate the information needed to assess the impact of geothermal energy development on the water-resources of the Mono-Long Valley Known Geothermal Resource Area (KGRA). Reliable information is required to determine the effect of geothermal development on the water quality of the KGRA. This paper will identify and describe the key water-related issues, inventory the existing water resource data, identify gaps and inadequacies in the existing data base, and recommend specific studies which would provide the decision-maker adequate information to ensure that geothermal energy development would occur in an environmentally acceptable manner. Water quality may be defined as the suitability of the water for its intended use; it is not an inherent property of a given water. For example, waters that are hot and have a high content of salts make excellent bathing sites but are very poor for drinking. Consequently, before an assessment can be made of the suitability of water of a certain quality, the intended uses of the water and their importance must be established. An important use of surface water flowing through the Mono-Long Valley KGRA is for municipal and industrial use. At present, water flowing from and through Long Valley accounts for about $40 \%$ of the water used by the City of Los Angeles (Eccles 1976). Other important uses of water in the KGRA which must be protected are for fish and wildlife habitat, recreation, and agriculture. Each has its specific quality requirements.

The first step in our analysis is to inventory the existing data base. Data will be presented and evaluated through basic hydrologic and mass balance principles. Conceptual models will be used to determine the functional relationships of the system. These models will allow us to predict how perturbations in specific system parameters (such as pressure decilines in the hot water resource due to geothermal energy development) will affect the water quality of the region.

\section{EXISTING DATA BASE}

Description of the Area

The Mono-Long Valley Known Geothermal Resource Area encompasses two distinct drainage basins, Mono Lake and Long Valley. The Sierra Nevada, which rise to a height of $13,000 \mathrm{ft}(4000 \mathrm{~m})$, form the western boundary of Mono Lake Basin; smaller hills and ridges form the northern, eastern, and southern boundaries. A major feature of the north end of the basin is Mono Lake. In 1976 it covered an area of $107 \mathrm{mi}^{2}(277 \mathrm{~km}$ ) and attained a depth of $150 \mathrm{ft}$ (46 m) (Mono Lake Comittee 1978). Long Valley is an $11 \times 20 \mathrm{mi}(17 \times 32 \mathrm{~km}$ ) ring-faulted elliptical depression on the east front of the Sierra Nevada, a caldera formed by the collapse of an ancient volcano. The major geothermal activity in the KGRA occurs in the western half of Long Valley. The walls of the caldera rise abruptly (up, to $3000 \mathrm{ft}$ or $915 \mathrm{~m}$ ) on all sides except the southwest, which opens toward Lake Crowley. Hydrothermal activity in Long Valley has been intermittent since it first underwent vulcanism during the Tertiary period (Bailey et a1. 1976). Most of the active hot springs are located on faults which originated in the Quarternary period. 
Hydrogeology

The water quality of Mono-Long Valley KGRA is a function of its geologic structural history. Hydrologic components, groundwater flow, and storage are largely determined by the subsurface strata. Piezometric pressure, location and extent of faulting, permeability of the sub-strata, recharge, and temperature gradients determine the flow of a geothermal fluid, and its chemistry depends upon the rock-composition, temperature, and pressure it has experienced. Water quality of the area depends generally upon the relative contributions of materials froin geothermal and freshwaters.

The Long Valley caldera was formed 0.7 million years ago during the eruption of the Bishop Tuff from a shallow magma chamber (Bailey et al . 1976). Subsequent glaciation, vulcanism, and inundation have produced a lithologic section that includes volcanic flows, tuffs, ash falls, glacial-outwash deposits, and Pleistocene lake sediments. Thus, the subsurface geology which determines the capability of the subterranean rocks to accept, store, and transmit water is very heterogeneous in the Long Valley-Mono Lake Basin.

The Sierra Nevada, which bound the Basin on the south and west, are mainly comprised of metamorphic and intrusive rocks. Since these rocks are of igneous origin or have been metamorphosed, they do not contain significant intergranular operings. As a consequence, water storage and transmission depend upon the degree of fracturing, jointing, and faulting present. Porous lava flows, tuffs, and breccia of the caldera contain intergranular pore space and are fragmental, which tends to make them a good reservoir for groundwater. Highly permeable, unsorted glacial deposits are interbedded with the lava flows.

Alluvial deposits occur in the floodplain of the Owens River, around Lake Crowley, at local creeks, and at mountain slopes at the foot of glacial moraines. They vary in thickness from a few feet to a depth of $945 \mathrm{ft}$ (288 $\mathrm{m}$ ) in the upper portion of the Mono Basin. The alluvial deposits are very capable of transmitting water and are a good groundwater reservoir. In areas in which hydrothermal alterations have occurred, the permeability has been reduced.

The California Department of Water Resources (1973) performed an extensive analysis of groundwater in the Mamnoth Basin. The study suggests that the groundwater basin is not a single saturated interconnected basin but rather a series of subbasins with restricted inflows and outflows. This is due to the heterogeneity of the subsurface geology. The California Department of Water Resources (1967) indicated that most of the underflow in the basin occurs in the fractured volcanics below glacial deposits.

The most comprehensive analysis of the hydrogeologic system in Long Valley has been performed by Sorey et al. (1978). They computed the porosity, permeability, and specific gravity from test drilling and seismic refraction resuits (Table 1). The large range in porosity and permeability can be attributed to the heterogeneity of the sub-strata. 
Table 1

LABORATORY DATA FOR SELECTED CORES FROM TEST HOLES IN LONG VALLEY CALDERA

(Sample analyses run by Hydrologic Laboratory, WRD, Denver, Colo., except as noted below.)

\begin{tabular}{|c|c|c|c|c|c|c|c|c|}
\hline No. & $\begin{array}{l}\text { Test hole } \\
\text { and location } \\
\end{array}$ & $\begin{array}{l}\text { Depth } \\
(\mathrm{m})\end{array}$ & $\begin{array}{l}\text { Lithologic } \\
\text { Description } \\
\end{array}$ & $\begin{array}{c}\text { Specific } \\
\text { Gravity } \\
\text { of soljds } \\
\left(\mathrm{g} / \mathrm{cm}^{3}\right)\end{array}$ & $\begin{array}{l}\text { Porosity } \\
\text { (percent) }\end{array}$ & $\begin{array}{l}\text { Permeabilititio } \\
\left(\mathrm{m}^{2} \times 10^{-15}\right)^{\mathrm{a}}\end{array}$ & 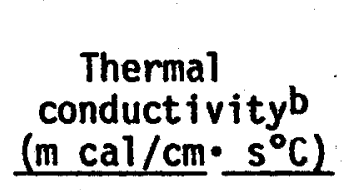 & $\begin{array}{l}\text { Electrical } \\
\text { resistivity } \\
\text { (ohm-m) }\end{array}$ \\
\hline \multirow[t]{8}{*}{$\mathrm{CH}-1$} & \multirow{8}{*}{$\begin{array}{l}\text { Near Cashbaugh } \\
\text { Ranch } \\
\text { 3S/29E-19C }\end{array}$} & 84 & $\begin{array}{l}\text { Tuffaceous (ashy) } \\
\text { sediments }\end{array}$ & 2.34 & 59.8 & $\begin{array}{r}8,300 \\
640\end{array}$ & $-\cdots$ & --- \\
\hline & & $\begin{array}{l}120 \\
133\end{array}$ & Sand " & $\begin{array}{l}2.40 \\
2.33\end{array}$ & $\begin{array}{l}35.0 \\
50.2\end{array}$ & -- & $-\cdots$ & ---- \\
\hline & & 146 & & 2.33 & 63.1 & 460 & 1.8 N.P. & $-\ldots$ \\
\hline & & $\begin{array}{l}157 \\
172\end{array}$ & $\begin{array}{l}\text { Silty ash } \\
\text { Tuffaceous sedi- } \\
\text { ments }\end{array}$ & $\begin{array}{l}2.37 \\
2.60\end{array}$ & $\begin{array}{l}56.9 \\
39.6\end{array}$ & $5.5 \times \frac{35}{10^{-4}}$ & $\begin{array}{l}1.9 \text { N.P. } \\
1.8 \text { N.P. }\end{array}$ & ---- \\
\hline & & 185 & $\begin{array}{l}\text { Ashy sediments, } \\
\text { clay alteration }\end{array}$ & 2.72 & 45.2 & $1.3 \times 10^{-3}$ & 2.1 N.P. & $\cdots$ \\
\hline & & $\begin{array}{l}209 \\
229\end{array}$ & $\begin{array}{l}\text { Pumiceous sand } \\
\text { Pumiceous tuffa- } \\
\text { ceous sediments }\end{array}$ & $\begin{array}{l}2.37 \\
2.69\end{array}$ & $\begin{array}{l}62.4 \\
62.3\end{array}$ & $\begin{array}{l}2.3 \times 10^{-3} \\
4.9 \times 10^{-3}\end{array}$ & $\overline{---}$ & $-\cdots$ \\
\hline & & 251 & $\begin{array}{l}\text { Pumiceous ( } c l \text { ay } \\
\text { alteration) }\end{array}$ & 2.67 & 52.1 & $1.0 \times 10^{-3}$ & 2.4 N.P. & $-\cdots$ \\
\hline & & 305 & Ash & 2.69 & 56.5 & $7.1 \times 10^{-4}$ & $\cdots-$ & $-\cdots$ \\
\hline $\mathrm{CH}-3$ & $\begin{array}{l}\text { West of Crow- } \\
\text { ley Lake } \\
3 S / 29 E-27 L\end{array}$ & 29 & Rhyol ite flow & 2.39 & 31.0 & $4.5 \times 10^{-3}$ & 2.3 N.P. & ---- \\
\hline $\mathrm{CH}-4$ & $\begin{array}{l}\text { East Rim } \\
3 S / 30 E-19 M\end{array}$ & 58 & Ash & 2.36 & 66.1 & $3.2 \times 10^{-1}$ & $2.1 \mathrm{N.P}$. & 260 \\
\hline
\end{tabular}


Table 1 (cont.)

\begin{tabular}{|c|c|c|c|c|c|c|c|c|}
\hline No. & $\begin{array}{l}\text { Test hole } \\
\text { and location }\end{array}$ & $\begin{array}{l}\text { Depth } \\
(\mathrm{m})\end{array}$ & $\begin{array}{l}\text { Lithologic } \\
\text { Description } \\
\end{array}$ & $\begin{array}{c}\text { Specific } \\
\text { Gravity } \\
\text { of soljds } \\
\left(\mathrm{g} / \mathrm{cm}^{3}\right)\end{array}$ & $\begin{array}{l}\text { Porosity } \\
\text { (percent) }\end{array}$ & $\begin{array}{l}\text { Permeabilitya } \\
\left(\mathrm{m}^{2} \times 10^{-15}\right)\end{array}$ & $\begin{array}{l}\text { Thermal } \\
\text { conductivity } \\
\left(\mathrm{m} \mathrm{cal} / \mathrm{cm} \cdot \mathrm{s}^{\circ} \mathrm{C}\right)\end{array}$ & $\begin{array}{l}\text { Electrical } \\
\text { resistivity } \\
\text { (ohm-m) }\end{array}$ \\
\hline \multirow[t]{2}{*}{$\mathrm{CH}-5$} & \multirow{2}{*}{$\begin{array}{l}\text { East of Whit- } \\
\text { more Hot } \\
\text { Springs } \\
4 S / 29 \mathrm{E}-5 \mathrm{~B}\end{array}$} & 122 & Pumiceous tuff & 2.32 & 46.6 & $-\cdots$ & 2.2 N.P. & ---- \\
\hline & & 214 & Tuff & ---- & 29.5 & $\cdots$ & 2.5 S.S. & $\cdots$ \\
\hline \multirow[t]{2}{*}{$\mathrm{CH}-6$} & \multirow{2}{*}{$\begin{array}{c}\text { Little Ante- } \\
\text { lope Valley } \\
3 S / 28 E-22 F\end{array}$} & 76 & $\begin{array}{c}\text { Clay-altered } \\
\text { tuff }\end{array}$ & 2.64 & 37.1 & $\cdots$ & 3.5 N.P. & --- \\
\hline & & 209 & $\begin{array}{l}\text { Altered } \\
\quad \text { (silicified) } \\
\text { tuff }\end{array}$ & 2.59 & 6.0 & $\cdots$ & 5.2 S.S. & $\cdots$ \\
\hline \multirow[t]{2}{*}{$\mathrm{CH}-8$} & \multirow{2}{*}{$\begin{array}{l}\text { Smokey Bear } \\
\text { Flat } \\
3 S / 28 E-18 D\end{array}$} & 57 & Rhyolite flow & 2.52 & 7.1 & $8.3 \times 10^{-2}$ & $-\cdots$ & 233 \\
\hline & & $\begin{array}{l}122 \\
183 \\
213 \\
305\end{array}$ & $\begin{array}{c}\text { Rhyolite tuff } \\
n\end{array}$ & $\begin{array}{l}2.33 \\
2.28 \\
2.30 \\
2.35\end{array}$ & $\begin{array}{l}35.2 \\
38.6 \\
46.1 \\
46.8\end{array}$ & $\begin{array}{r}180 \\
36 \\
34 \\
14\end{array}$ & $\begin{array}{l}2.3 \mathrm{N.P} \\
2.3 \mathrm{N.P} \\
2.0 \mathrm{N.P}\end{array}$ & $\begin{array}{l}130 \\
190 \\
780 \\
360\end{array}$ \\
\hline \multirow[t]{2}{*}{$\mathrm{CH}-9$} & \multirow{2}{*}{$\begin{array}{l}\text { Upper Dry } \\
\text { Creek } \\
3 \text { S/27E-2OH }\end{array}$} & 42 & Basalt flow & 2.87 & 13.9 & $5.5 \times 10^{-2}$ & 3.6 S.S. & 800 \\
\hline & & 54 & Andesite flow & 2.66 & 10.2 & $7.2 \times 10^{-4}$ & $\cdots$ & --- \\
\hline
\end{tabular}

aComputed from vertical hydraulic conductivity measurement run with water matching chemical composition of appropriate ground water, at temperature of $16^{\circ} \mathrm{C}$.

bN.P. signifies needle probe measurement; data for $\mathrm{CH}-1,4,5,6,8(183 \mathrm{~m})$ run in Heat Flow Laboratory, Geologic Division, Menlo Park, Calif. S.S. signifies divided bar, steady-state conductivity measurements made in Menlo Park Heat Flow Laboratory. All measurements made on water-saturated samples.

Source: Sorey et al. (1978) 
Regional Hydrology

In order to determine the amount of water available for geothermal energy development, as well as any effects of development on the hydrology and water chemistry of the area, the quantities and qualities of the major sources of freshwater and geothermal fluids need to be established. This can be done through conceptual hydrologic and mass balance models. The hydrologic balance can be estimated by the equation:

$$
\begin{aligned}
& \text { Inflow (precipitation + surface inflow + subsurface inflow) }= \\
& \text { Outflow (consumptive use + surface outflow + subsurface outflow) } \\
& + \text { Change in lake storage + Change in groundwater storage }
\end{aligned}
$$

Sorey et al. (1978) calculated a hydrologic budget for the Long Valley Basin (Table 2). The total average inflow exceeded outflow by about 3.2\%. Part of the imbalance could be attributed to unmeasured groundwater interflow in Lake Crowley.

\section{Precipitation}

About $70-80 \%$ of the precipitation in the KGRA occurs as snow from Pacific winter storms. The remaining 20-30\% falls during summer thunderstorms (Table $3)$. The orographic effect of the Sierra Nevada greatly affects the amount of precipitation that occurs in the KGRA. In areas near the crest of the Sierra Nevada, such as Mammoth Pass, the average annual precipitation is about 56.5 in/yr. Long Valley Dam, which lies in the rain shadow, receives only 9.6 in/yr.

\section{Surface Water Flows}

Surface water flow in the Long Valley Basin has been well characterized by the California Department of Water Resources (1967) survey, which is based on records from the Los Angeles Department of Water and Power (LADWP) from the period 1942-1965. Surface inflow from the Long Valley Basin into Lake Crowley was 214,000 acre $\mathrm{ft} / \mathrm{yr}$; 9620 acre $\mathrm{ft} / \mathrm{yr}$ of this was estimated as the loss by evaporation (Table 4). The most important sources of surface water in Long Valley include Hot Creek (called Mammoth Creek west of Highway 395), which drains the northwestern part of the valley, and the Owens River. Convict, McGee, and Hilton Creeks flow from the eastern slopes of the Sierra Nevada directly into Lake Crowley.

The major source of controlled surface flow to Long Valley is the Mono Craters Tunnel. The average annual water diversion from Mono Basin through the tunnel is about 110,000 acre $\mathrm{ft} / \mathrm{yr}$ (Winkler 1977). Nearly all of the surface runoff from Walker, Rush, Parker, and Lee Vining Creeks is diverted into the Mono Craters Tunnel from the east slope of the Sierra Nevada. The California Department of Water Resources (1964) estimated the mean runoff for Mono Basin at 216,000 acre $\mathrm{ft}$.

\section{Groundwater Flow}

Recharge in Long Valley occurs through the regional glacial moraines on the steep slopes of the Sierra Nevada and to a lesser extent from local precipitation. Most of the water percolates within the fractured volcanics and 
Table 2

WATER BUDGET FOR THE LONG VALLEY DRAINAGE BASIN

FOR WATER YEARS 1964-74

Inflow

Owens River below East Portala

Hot Creek at the gorgeb

McGee Creek

Convict Creek

Hilton Creek

Rock Creek Diversionc

Laurel Creekd

Crooked Creek

Precipitation on Lake Crowleye

Ungaged inflowf

Total inflow (rounded) 10,900
$\underline{L / S}$

5,140

1,810

930

805

344

293

168

113

168

1,090

9,670

508

430

469

121

110

$-90$

$\underline{\mathrm{hm}^{3} / \mathrm{yr}}$

162.3

57.1

29.4

25.4

10.9

9.3

5.3

3.6

5.3

34.5

343.0

Main venturi at Long Valley Dam

Evaporation from irrigated grasslandh

Evaporation from Lake Crowley ${ }^{1}$

Owens River gorge, Main Weir

Ground-water loss to regional system

Change in reservoir storage, 1964-1974

Total outflow (rounded)

11,200

305.3

16.0

13.6

14.8

3.8

3.5

$-2.8$

354.0

a Includes water imported from Mono Lake basin: $113.2 \mathrm{hm}^{3} / \mathrm{hr} \quad(3,590$ $L / S)$ average for the 11 -year period of record.

bIncludes discharge from the Hatchery springs and hot springs in Hot Creek gorge.

CPeriod of record: 1966-1974 water years.

dperiod of record: $7 / 70-7 / 73$, from Calif. DWR (1973).

eAverage $25 \mathrm{~mm}$ on $21 \mathrm{~km}^{2}$ of lake surface.

fincludes recoverable water from ungaged drainage and all spring discharge except as described in $b$ above.

gFrom $85 \mathrm{~km}^{2}$ area where water table is less than $2.4 \mathrm{~m}$.

hSame as from a lake--690 m; $19 \mathrm{~km}^{2}$. irrigated.

iAverage $690 \mathrm{~mm}$ from $21 \mathrm{~km}^{2}$ lake surface.

Source: Sorey et a1. (1978) 
Table 3

PRECIPITATION (inches)

(1951-1970)

\begin{tabular}{lccc} 
& $\begin{array}{c}\text { Long } \\
\text { Valley } \\
\text { Reservoir }\end{array}$ & $\begin{array}{c}\text { Cain } \\
\text { Ranch }\end{array}$ & $\begin{array}{c}\text { Lake } \\
\text { Mary } \\
\text { Store }\end{array}$ \\
\cline { 2 - 4 } Jan. & 2.20 & 1.98 & 5.30 \\
Feb. & 1.68 & 1.39 & 3.66 \\
Mar. & 0.93 & 1.03 & 3.55 \\
Apr. & 0.93 & 0.74 & 2.42 \\
May & 0.53 & 0.60 & 1.64 \\
June & 0.23 & 0.42 & 0.91 \\
July & 0.51 & 0.45 & 0.82 \\
Aug. & 0.24 & 0.30 & 0.70 \\
Sept. & 0.20 & 0.41 & 1.11 \\
Oct. & 0.20 & 0.50 & 1.04 \\
Nov. & 1.19 & 1.46 & 3.22 \\
Dec. & 1.92 & 1.90 & 5.09 \\
Total & 10.76 & 11.18 & 29.46
\end{tabular}

Source: Monoplan Associates (1972)

PRECIPITATION EXTREMES (inches)

Long

Valley

Reservoir

1942-197

20.86
(1969)

20.86
$(1969)$

\subsection{2}

(1947)
Lake

Mary

Store

Period of Record

Cain

Ranch

1931-1971

1947-1972

(year)

18.86

(1938)

40.30

Lowest Precip. (year)
2.73
(1947)

Highest Monthly Precip. 10.41 (month-year)

$\begin{array}{cc}11.28 & 21.10^{\mathrm{a}} \\ (\text { Dec. 1955) } & (\text { Dec. 1955) }\end{array}$

apartial record, some spill

Source: Monoplan Associates (1972) 


\section{LAKE CROWLEY HYDROLOGIC BALANCE a}

\section{Station}

Surface Flow at Lake Crowley Out let

Evaporation at Lake Crowley

Change in Storage at Lake Crowley

TOTAL OUTFLOWd

\section{Owens River below East Portal}

Mono Craters Tunnel

$$
\text { East Portal Outlet }
$$

Mono Craters Junnel Make

$\overrightarrow{0} \quad$ Owens River above East Portal

Hot Creek at County Road Mamoth Creek at Highway 395 State Fish Hatchery Springse Hot Springs along Hot Creek Gorge $f$

Convict Creek at DWP Gaging Station

McGee Creek at Highway 395

Hi]ton Creek at Highway 395

SUBTOTAL INFLOW
Flow

Acre-feet Percentc Acre-feet Percentc
Flow Acre-feet Percentc

\begin{tabular}{rr}
200,800 & 93.8 \\
9,260 & 4.2 \\
4,040 & 2.0 \\
\hline 214,100 & 100.0
\end{tabular}

$107,510 \quad 50.2$
17,820

8.3

$\begin{array}{ll}36,250 & 16.9 \\ 14,630 & 6.8 \\ 14,500 & 6.8 \\ 11,500 & 5.4\end{array}$

$40,630 \quad 19.0$

16,910

20,850

7,410

7.9

9.7

193,310

90.3 
Table 4 (cont.)

\section{Station}

Minor Streams 9

Little Hot Creek near Source

Surface Flow from Alkali

Lakes and Vicinity

Surface Flow near North

Landing

Whitmore Hot Springs

Springs near mouth of

Watterson Canyon
Flowb Acre-feet Percentc
Flowb Acre-feet Percentc

$\begin{array}{rr}1,000 & 0.47 \\ 4,000 & 1.87 \\ 100 & 0.05 \\ 500 & 0.23 \\ 1,000 & 0.47\end{array}$

\section{Estimated Unmeasured Contribution to Lake Crowley ${ }^{h}$}

TOTAL INFLOW

Flow
Acre-feet
Percentc

$6 ; 600$

3.1

a Average annual flow in acre-feet for 1942-1965, calendar year; change in storage based on fiscal year. Except as noted, all values determined from DWP long-time records.

bFlows listed in this column are tributary to those flows listed in the adjacent column to the right.

CFlow as a percent of outflow plus evaporation and change in storage for Lake Crowley.

dAverage annual evaporation determined by DWP. Average annual change in storage computed from DWP statistical reports.

eEstimated from the State Fish Hatchery (1960-66) measurements of spring flow.

fCalculated from flow of Hot Creek at County Road minus Marmoth Creek and State Fish Hatchery Springs flow.

GBased on DWR June 1966 measurements.

hEstimated from total outflow minus measured inflow.

Source: California Department of Water Resources (1967) 
metamorphics but reappears as surface flows in the basin. Shallow groundwater flows follow the regional topography of the basin. Groundwater flow patterns have been developed by the California Department of Water Resources (1973) from hydraulic potential information that was obtained from seven wells. The data suggest that a shallow, unconfined groundwater system 1ies 2-45 ft $(0.6-14 \mathrm{~m})$ below the land surface from the Sierra Nevada to Lake Crowley (California Department of Water Resources 1967.). A shallow groundwater reservoir lies below the unconfined aquifer system near Lake Crowley and along the Owens River above the lake (Eccles 1976).

Lachenbruch et al. (1976) measured temperatures in 29 shallow drill holes to better characterize the groundwater system in Long Valley. They were able to delineate three regions of origin. In areas in which the temperature at a depth of $10 \mathrm{~m}\left(33 \mathrm{ft}\right.$ ) is less than $11^{\circ} \mathrm{C}$, there are essentially no gradients up to $30 \mathrm{~m}(98 \mathrm{ft})$ in depth. This suggests that the heat from greater depth is being absorbed by moving groundwater, which is a condition characteristic of zones of hydrologic recharge. The second region exhibited temperatures between $11^{\circ} \mathrm{C}$ and $16^{\circ} \mathrm{C}$ at $10 \mathrm{~m}$. In these areas, the gradients are $200-400^{\circ}$ $\mathrm{c} / \mathrm{km}$. This is characteristic of conductive regimes to substantial depth. The third region was characterized by temperatures which exceeded $16^{\circ} \mathrm{C}$ at $10 \mathrm{~m}$. This region has irregular gradients and heat flows to 50 HFU ( 1 HFU $=10^{-6}$ $\mathrm{cal} / \mathrm{cm}^{2} \mathrm{sec}$ ), which is characteristic of zones of hydrologic discharge. From the temperature measurements, water table elevation and isotopic data on concentrations of oxygen-18 and deuterium, Lachenbruch et al. (1976) mapped groundwater flows (Fig. 1). Shallow groundwater recharge occurs at the periphery of the caldera and moves laterally toward the hot springs, mixing with local hydrothermal discharges along faults. Since much more water is available for recharge at the western and southern rim of the Sierra Nevada, as compared to the eastern rim of the caldera, groundwater flow is from west to east.

Groundwater movement in the Mono Lake Basin is similar to the freshwater movement of Long Valley Basin. Recharge is through unconsolidated alluvial deposits and fractured volcanic material. It follows the regional topography flows toward Mono Lake. There are artesian wells in the vicinity of Mono Lake which indicate that areas surrounding portions of the lake are overlain by fine grained confining sediments (Lee 1969). Water levels are close to the surface at Mono Lake but may be as much as 300-400 ft (91-122 m) below the recharge areas along the higher alluvial slopes.

\section{Hydrology of the Hot Springs}

The hydrology and chemical nature of the hot springs in the KGRA is a function of their origin and the degree of mixing that has occurred with surface and groundwaters. Most of the hot springs, fumaroles and thermally altered rock occur along faults. Deep-seated geothermal fluids rise from the magma in the form of superheated vapor. As they rise to the surface through faults, the temperatures and pressures of the vapors are reduced, allowing the nonvolatile elements to precipitate. Cold groundwater of local origin, which tends to be dominated by calcium and bicarbonate with very low concentrations of other chemical constituents, moves laterally and mixes with highly mineralized geothermal fluids. The temperature and chemistry of the springs depend upon the amount of mixing with the shallow groundwater which, in turn, is a function of subsurface geology and location in the basin. 


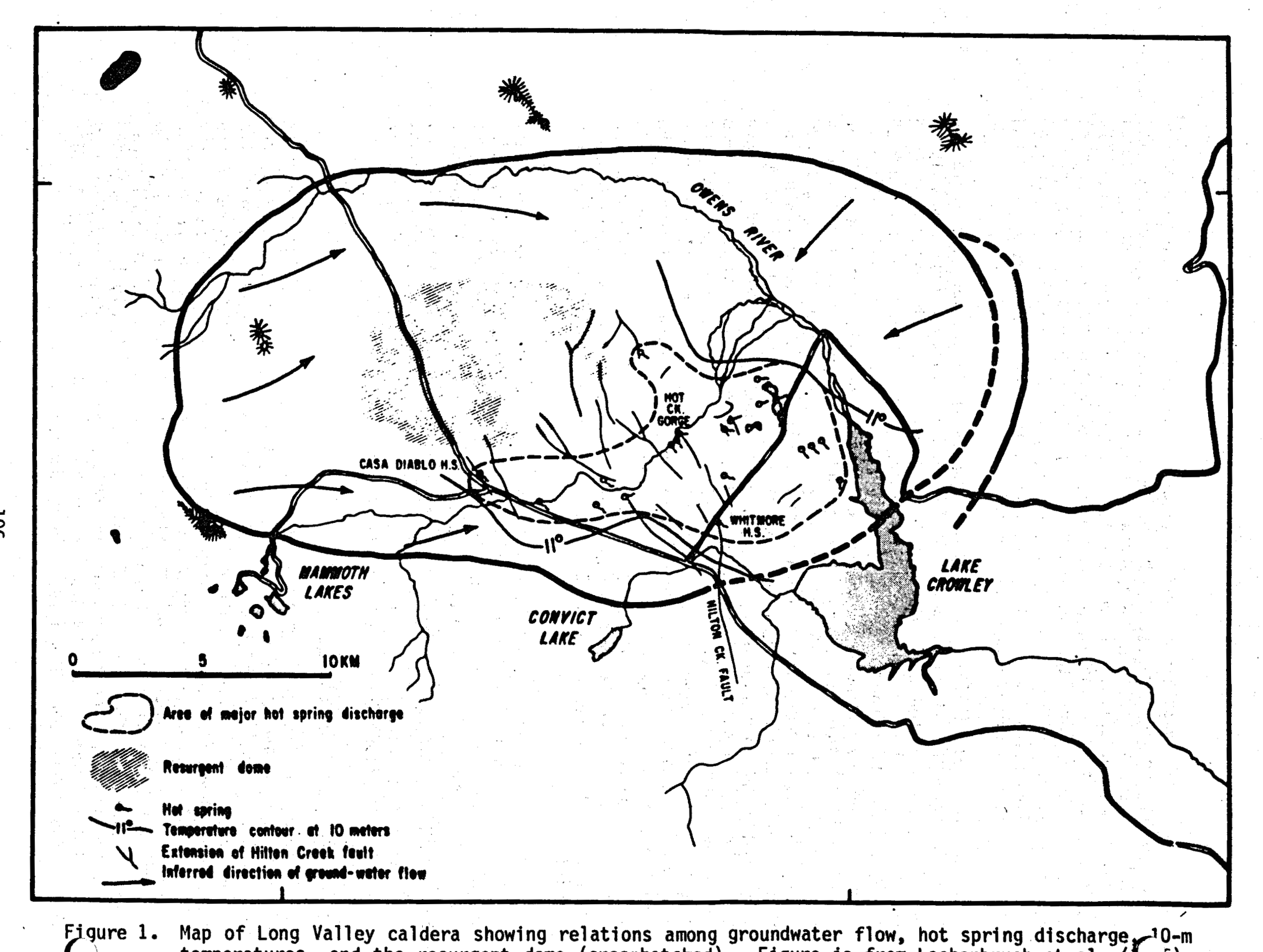


The various springs in Long Valley do not have the same origin. The hot springs directly tributary to Hot Creek are primarily controlled by faulting. These springs are the hottest and have the highest trace metal content and total dissolved solids of any in the basin (California Departiment of Water Resources 1967). This indicates that the geothermal waters in this area rise along fractures which offer little resistance to flow and, as a result, experience very little mixing. Waters emanating from Chance Spring, Hot Creek Fish Hatchery, and Hot Creek Ranch springs are fed from shallow groundwater that originates off the Sierra Nevada and emerge from glacial deposits which are overlain by impermeable basalts flows. Even though the fish hatchery springs emit $9035 \mathrm{gal} / \mathrm{min}$ ( 570 liters/sec) and comprise $74 \%$ of the total thermal spring discharge, they account for only $7 \%$ of the total hot geothermal water discharged in Long Valley (Sorey 1976). The quality of this water is variable depending upon the amount of mixing with geothermal fluid. Large seasonal variations in temperature and chemistry indicate the importance of mixing of geothermal and surface waters. The thermal springs near the Alkali Lakes and Alkali Pond have a slightly different chemical characteristic than the aforementioned springs. These waters range from $39^{\circ} \mathrm{C}$ to $65^{\circ} \mathrm{C}$, are more alkaline, and are generally low in divalent cations (Californta Department of Water Resources 1967). They are fed by upwelling of mixed geothermal and surface waters that are concentrated by evaporation, thus creating their high concentrations of total dissolved solids.

\section{Fluctuations in Spring Discharge}

Emissions from specific springs change with time. Geologic activity, such as earthquakes, may open new faults and create new springs. New springs were observed on August 24, 1973 just after an earthquake occurred near Long Valley (Eccles 1976). Precipitation of silica, mineralization, and thermal alteration are continually occurring, gradually occluding existing springs.

Eccles (1976) studied the sources of arsenic and general chemical constituents in streams tributary to Lake Crowley. He concluded that the origin of arsenic is the geothermal fluid which emanates from the hot springs and fumaroles. Because the hot springs in Hot Creek Gorge contribute about $60 \%$ of the arsenic discharged into Lake Crowley, they were further investigated. A salinity-seepage survey was used to determine the volume and chemical concentration of water gained or lost in several reaches of the stream. The majority of the chemical seepage into the gorge was found to be from localized spring complexes, although some seepage appeared to be continuous throughout the entire reach of the stream. Analyses were performed from two to six different times over the survey period revealing some temporal variability in the data. Even though flow varied considerably, the overall mass of arsenic discharged from Hot Creek did not change considerably with time.

\section{Water Chemistry}

Water chemistry has been used to characterize systeriatic differences between geothermal fluids and non-thermal waters. The California Department of Water Resources (1967) performed detalled chemical analyses of water to determine the effect of geothermal fluids discharged from natural sources on the water quality in Long Valley (Table 5). The Department reported that the discharge of geothermal fluids could degrade water quality in Long Valley and "constitute a threat of pollution to the water supply of the Los Angeles-Owens River 
Table 5

WATER QUALITY DATA ON SELECTED STREAMS ENTERING THE CROWLEY LAKE-OWENS RIVER SYSTEM

Stream

Mammoth Creek at Hwy. 395

State Fish

Hatchery Spgs.

Hot Springs along Hot Creek Gorge

\section{Convict Creek at} DWP Gaging Sta.

McGee Creek at

Hwy. 395

Hilton creek at Hwy. 395

Little Hot Crk. near source

\section{$\frac{\text { Annual Flow }}{\text { Acre-feet Percenta }} \frac{\text { Arsenic }}{\text { ppm Tons/Yr Pe }}$}

\section{Average}$$
14,630
$$

$$
14,630
$$$$
6.8
$$$$
0.003
$$

0.1

0.2

0.14

2.8

$1.4 \quad 0.03$

0.6

0.3

$$
14,500
$$$$
6.8
$$

0.044

$$
0.9
$$

6.1

0.25

4.9

2.4

11,500

5.4

9.2

62.2

$-$

89.5

44.0

$0.21 \quad 4.1$

1.8

$$
16,910 \text {. }
$$$$
7.9
$$

$$
-
$$$$
\therefore \quad 0.03
$$

0.7

20,850

9.7

$$
-
$$$$
-
$$

0.05

1.4

$$
7,410
$$$$
3.5
$$$$
-
$$$$
\text { - }
$$

0.03

0.3

1,000

$$
0.47 \quad 0.75
$$

1.0

$-$

8.8

12.0

$-$

$10.00 \quad 13.6$

Surface Flow from Alkali Lakes and Vicinity

$$
4,000
$$

$$
1.87 \quad 0.60
$$

3.3

$-$

$8.0 \quad 43.5$

$-$

TOTALS

90,800

$42.4 \quad 1.397 \quad 14.5$

68.9

$17.3 \quad 155.1$

$\begin{array}{llll}47.8 & 21.53 & 177.1\end{array}$

45.7

Curce: California Department of Water Resources (1967) 
Aqueduct." The state report further suggested that the Los Angeles Department of Water and Power monitor fluxes of arsenic concentration into Lake Crowley and take remedial action if the influxes of geothermal fluids from hot springs approached the EPA standard of $0.1 \mathrm{ppm}$ arsenic. The Department of Water Resources reemphasized the policy established by the Lahontan Regional Water Quality Control Board of precluding geothermal waste discharges into Long Valley.

The California Department of Water Resources (1967) also made a comparison of runoff and arsenic ion concentration at Hot Creek Gorge. They found a strong correlation between ion concentration and flow. A chloride-runoff plot prepared by the Department indicated that simple dilution is the only factor responsible for changes in chloride ion concentration. This suggests that there is a virtually constant source of chemical constituents emanating from the not springs along Hot Creek, a reasonable conclusion since it is known that geothermal fluids are of wide areal extent and deep-seated origin.

Mariner and Willey(1976) performed extensive chemical analyses to determine the histories of the water in Long Valley and to determine the temperature of the waters in the geothermal reservoir utilizing quantitative chemical geothermometers (Table 6). They illustrated the mixed character of most of the hot springs with isotope data for deuterium and oxygen-18. The hot springs issue sodium-bicarbonate to sodium-bicarbonate-chloride type waters which are relatively high in total dissolved solids, bicarbonate, chloride, boron, arsenic and fluoride. Freshwaters outside the caldera are calcium-bicarbonate type waters with a very low total dissolved solid content. As water progresses from the freshwaters to the thermal water, the proportion of divalent cations, especially calcium, relative to sodium and potassium, markedly decreases. The warm springs and shallow ground water in the Long Valley caldera have a composition intermediate to the freshwater and the hot springs. Between Hot Creek and Lake Crowley, the shallow aquifer has been contaminated by thermal fluid. Chloride concentrations and temperature data indicate that chloride-rich geothermal waters are being introduced into the zone of saturation in Hot Creek Gorge. If only simple mixing were controlling the chloride concentrations and spring temperature, a plot of chloride versus temperature should yield a straight 1ine. This is not the case. Data from springs plot above the ideal mixing composition, suggesting that vapor loss or conductive cooling is occurring.

The Mono Lake Basin has water of various qualities. The freshwater from the Sierra Nevada is calcium bicarbonate in nature with a very low TDS concentration, averaging less than $50 \mathrm{mg} / 1$ at the higher elevations (California Department of Water Resources 1967). Water from Warm Springs has a total dissolved solids content in excess of $2000 \mathrm{ppm}$. Mono Lake has a very unusual chemistry. Unlike most waters with high dissolved solids, the lake is sodium chloridecarbonate in nature. It had a TDS content greater than 76,000 ppm in 1964 (Lyon and Lee 1968). Salinity increased 50 percent from 1948-1968 due to diversion of fresh water away from the lake by the Mono Craters Tunnel (Winkler 1977).

Trace element analyses of Long Valley waters were done by the California Department of Water Resources (1967) and are shown in Fig. 2. These data are good indicators of the natural levels of geothermal flow and can be used to demonstrate the spatial variability of geothermal effluent. 
Table 6

SELECTED CHEMICAL CONSTITUENTS, TEMPERATURES AND ISOTOPIC COMPOSITIONS FOR THERMAL AND NON-THERMAL WATERS FROM LONG VALLEY.

(Data for locations 1 through 10 from Mariner and Willey (1976); sampled in 1972 . Chemical data for locations 12,13 , and 21 from Lewis (1974). Locations 11 through 19 collected by M. Sorey (September 1975), 180 analyzed by $N$. Nehring, D analyzed by $D$. White, $C l$ analyzed by L. Tanner. Locations 20 through 25 collected by $B$. Evans (June 1976), D analyzed by D. White. Chemical concentrations are in milligrams per liter.)

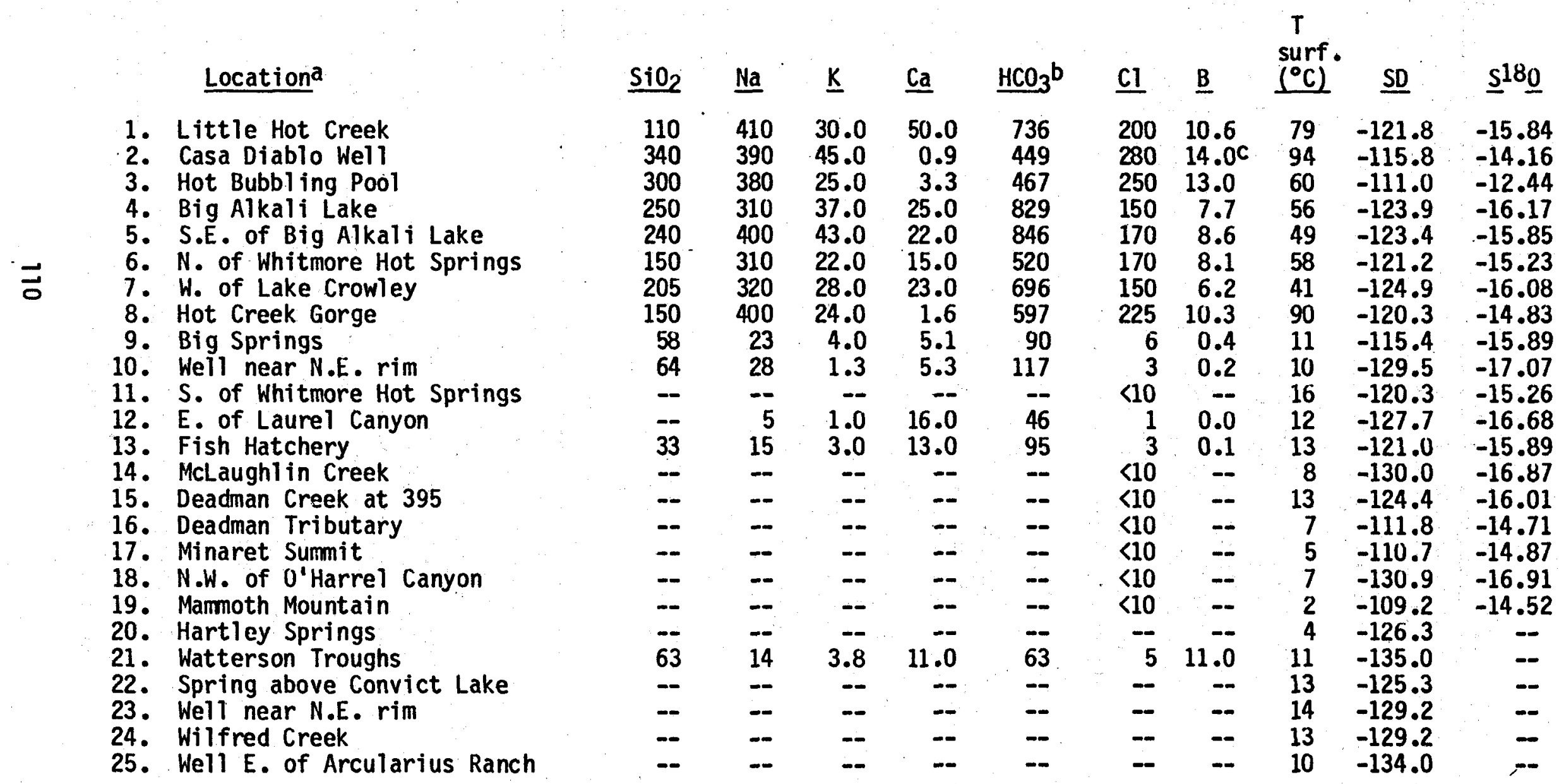

Metailed locations are given in Sorey et al. (1978) verage value for 12 samples from Mariner and Willey (1976) and Cal if. DWR (1967)
source: Sorey et al. (1978)

bTotal alkalinity calculated as $\mathrm{HCO}_{3}$ 

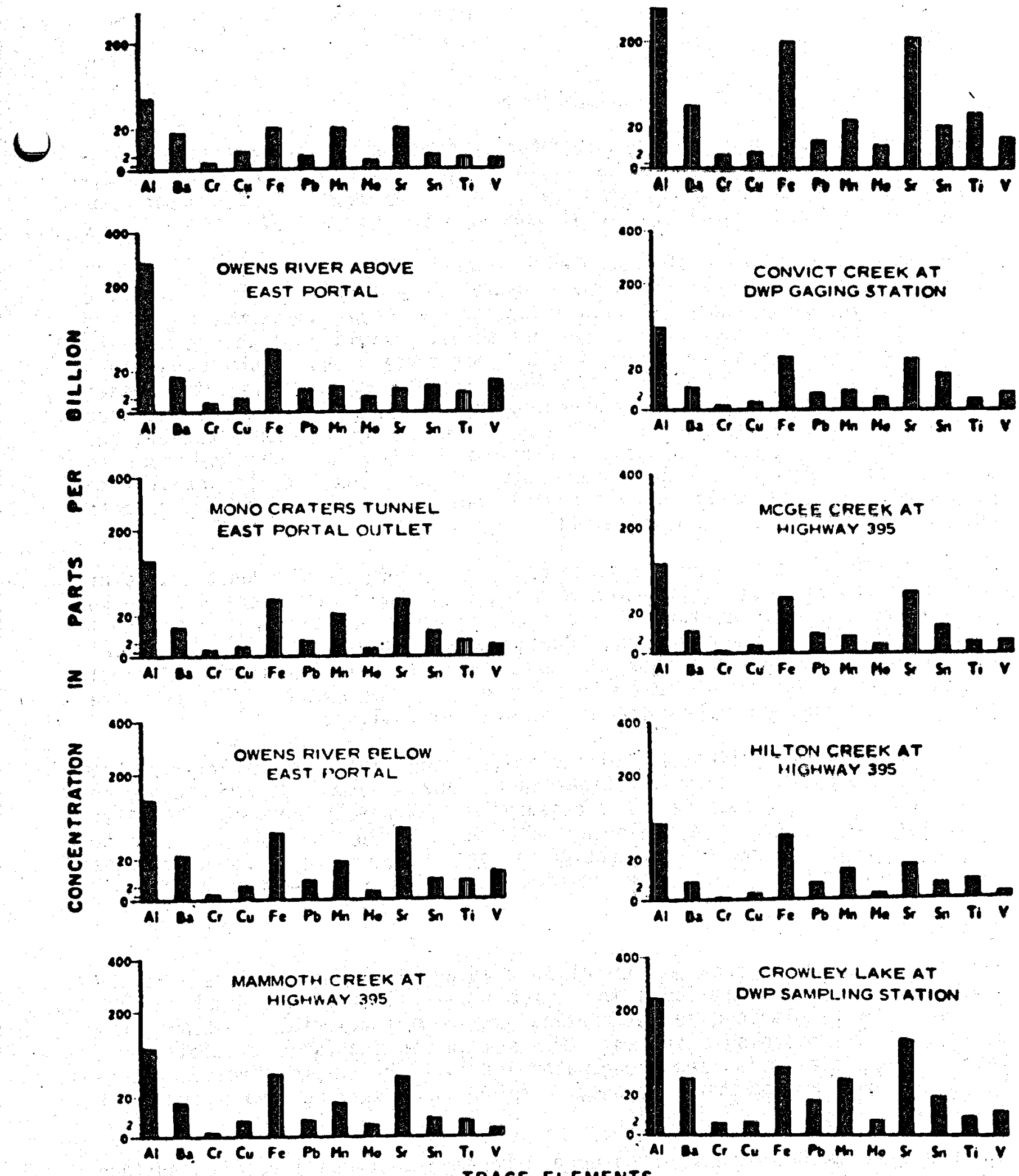

TRACE ELEMENTS

Figure 2. Occurrence of trace elements in selected surface waters. Data are from the California Department of Water Resources (1967). Bar graphs are based on an average of 3 to 6 spectrographic analyses for the period 1957 to 1964. Samples were collected and analyzed by the Los Angeles Department of Water and Power. 


\section{DATA GAPS}

The preceding section described the information attained from existing hydrologic and water chemistry studies in the Mono-Long Valley KGRA. What additional information is needed to predict and/or monitor the impact of geothermal development on the beneficial uses of water in the KGRA

Water acts as a conveyer of suspended sediments and dissolved salts, as well as a reactant in chemical weathering (hydration and hydrolysis). The toxic and hot nature of geothermal fluids is due to the extensive weathering of the host rock at high temperatures and pressures. Fluid emanates toward the surface through faults and is diluted by c00l surface and groundwaters which are low in salts and heavy metals. The changes that occur as water passes through the environment can be determined by conceptualizing a mass balance model consisting of source terms (inputs), storages in various locations and forms, transport among storages, transformation from one chemical form to another, and outputs to the surroundings. Such a model could actually be developed and could prove to be a useful tool for evaluation of any impacts due to geothermal resource development.

Geothermal fluids are responsible for most of the undesirable constituents of the water in the KGRA (California Department of Water Resources 1967). The concentration and temperature of these constituents are diluted by the cool groundwater and surface waters. Quantitative knowledge about the local hydrologic system and the mass of toxic materials emitted from geothermal sources will allow us to predict how geothermal development will affect the flow of water and materials which determine water quality.

It is impossible to collect all of the information needed to characterize the hydrology and chemical transformations in the environment. We need to decide what additional information is necessary to adequately protect the water quality of the area. The following sections describe the data required to make the hydrologic and mass balance models sensitive enough to detect changes in the environment. These data requirements are also summarized in Table 7.

\section{Hydrology}

Hydrologic processes are the principal driving forces which determine the amount of freshwater available for cooling and diluting geothermal fluids. Data need to be obtained and synthesized which will describe the basic components of the hydrologic system. The system has inputs of precipitation, recharge, surface inflow and groundwater inflow. The outputs include evapotranspiration, groundwater seepage, pumping, and surface and groundwater outflow.

The Los Angeles Department of Water and Power has adequate data on surface inflow and outflow for the KGRA. Additional data will be required only in the specific localities where development takes place. Precipitation measurements for the entire area are sparse. Winkler (1977) and Sorey et al. (1978) had to interpret precipitation data from various weather station averages, allowing for effects of altitude, orientation, slope and exposure. More data are needed to estimate accurately the rate of groundwater inflow, outflow, interflow and evaporation in the Long Valley and Mono Basins. 
Local Water Supplies

An area-wide hydrologic study is needed if extensive amounts of groundwater are going to be extracted for geothermal energy development and production, especially if wet cooling towers are utilized. It is important to monitor groundwater levels to ensure that the water extracted from the groundwater reservoir does not exceed the quantity of water that is returned. Otherwise, development might reduce both the quantity and quality of groundwater. overdraft may deplete perched groundwater reservoirs and not replenish them. Decreased groundwater flows may reduce the amount of water available to dilute geothermal waters. In order to determine the amount of groundwater available for extraction, groundwater measurements need to be taken before development begins. This type of information is essential to monitor and manage the changes that occur in the groundwater. Test wells need to be drilled to determine water table elevations, depth of the water table, permeabilities, and the water bearing characteristics of the groundwater reservoir. Groundwater level information can be recorded by contour maps which may convey details on changes in water table elevation and storage with time, and which may then be used to determine the rates of groundwater movement which are dependent both on the conductivity of the geologic material and the hydraulic gradients described by water table contours. Extracting geothermal or groundwaters will change the flow regime around the well because it will lower the piezometric surface locally. Observation wells are needed to monitor the water table and also to ensure that the groundwater resource is not depleted with time. They will also provide much needed information on seasonal variability and ranges in groundwater flow.

Communication Between Surface Water, Groundwater, and Geothermal Water

Investigation of groundwater basins begins with a determination of the size and shape of the reservoir. The surface area has been generally well defined through topographic maps of the region. The California Department of Water Resources (1967) and Sorey et al. (1978) have characterized the overall groundwater level and subsurface structure of the Long Valley region. However, this characterization is not in sufficient detail in either time or space to detect changes which might be induced by geothermal energy development. The hydrogeologic regime is probably too heterogeneous to allow construction of models of sufficient detail and adequate sensitivity to determine direction and flow of the groundwater in the whole region. Nevertheless, site-specific hydrogeologic studies would be useful in areas in which the beneficial uses are potentially threatened by development, such as the California Department of Fish and Game, Hot Creek Fish Hatchery and Hot Creek itself. Geothermal energy development could adversely affect the productivity of the fish hatchery by lowering the temperature of the water of the springs. In such areas, it may be possible that information is sufficient to allow construction of useful models.

As shown on Fig. 3, the fluid flowing out the hot springs is a mixture of hot (deep geothermal) fluid and cold (shallow) water. Removal of the hot geothermal fluid will decrease the hydraulic potential and will produce a "point sink" at the bottom of the production hole. The reduction of potential caused by creation of a point sink will tend to divert the flow towards the production hole. Therefore, the rising hot fluid at the bottom of hot springs will gradually lose its strength, and the amount of hot water contributed will gradually decrease. The continuation of this process may result in pro- 


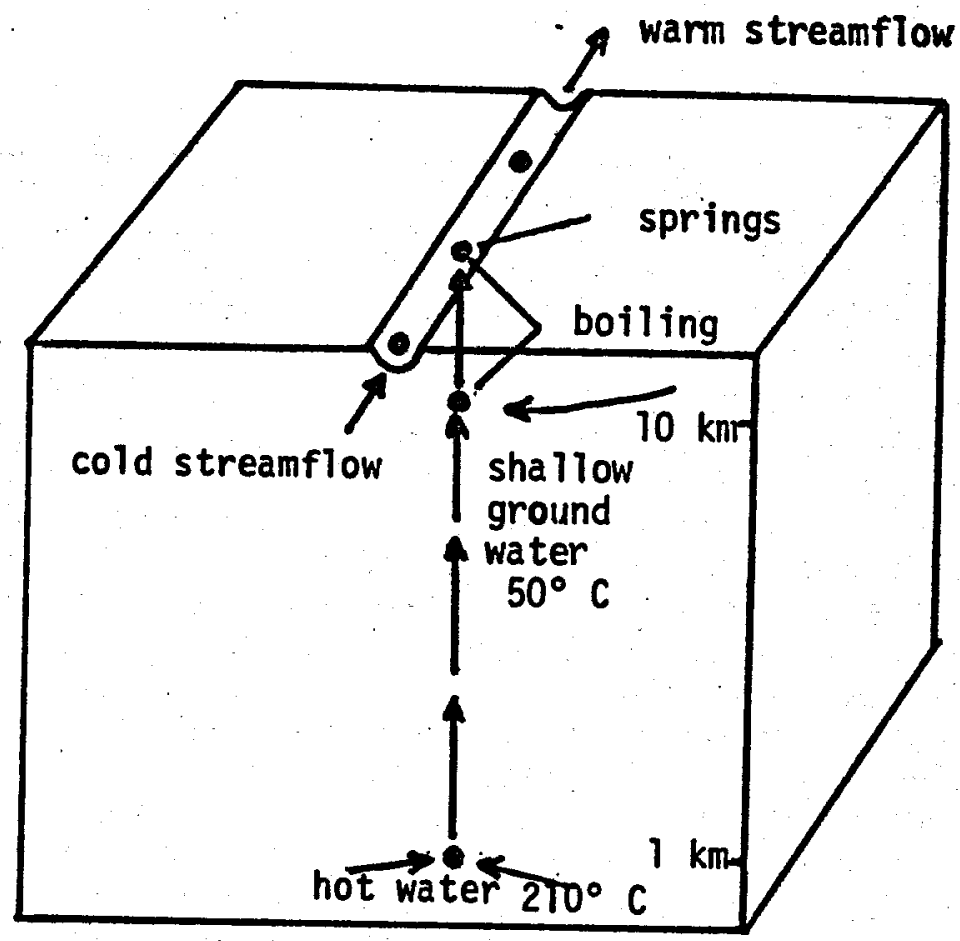

Diagram of Hot Creek Gorge Spring System

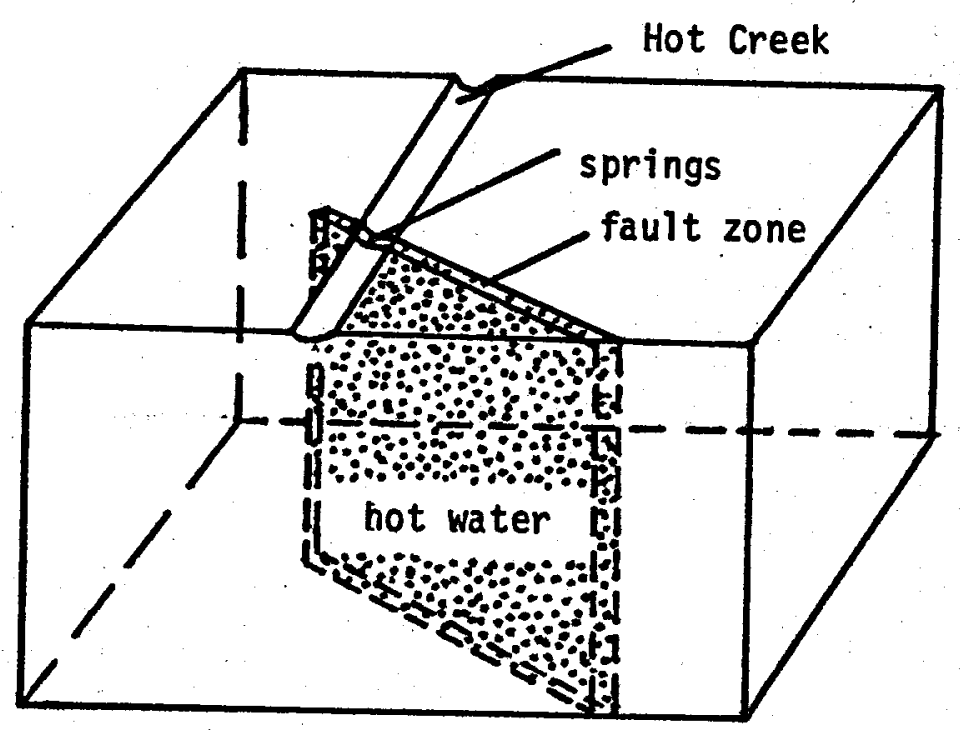

Slab Model for Spring Flow in Hot Creek

Figure 3. Block diagram of a hot spring (from Sorey and Lewis 1976) 
gressive reduction in the temperature of the hot springs. While these processes are occurring, the chemistry of the hot springs can be expected to change gradually.

Studies are needed to determine any communication between the geothermal water flows and the groundwater flows to the Fish Hatchery Springs. A deep test well needs to be drilled which will delineate the source of the cold water and the zones which supply the geothermal fluid to the springs. The well will change the resultant water table form, called the zone of depression. Graphical relationships, between the change in water level due to the well (drawdown) and time, can be used to solve the Theis equation. If one takes into account boundary effects (interference of several wells or effect of an intersecting stream on the drawdown), the Theis equation can be used to estimate the effect of the well on the water table. Pumping tests of the production well and adjacent observation wells are needed to estimate the Theis solution. These tests will help locate faults, fractures, and impermeable layers which are extremely important in understanding the movements of underground fluids.

The pumping tests will also enable us to estimate some of the aquifer characteristic coefficients such as permeability, storage, and transmissivity. If these aquifer characteristic coefficients are determined in advance, the effects of geothermal fluid withdrawal production and reinjection of fluids on the hot springs can be estimated. These test wells will yield baseline information on the lateral variability of hydrologic conditions near the springs.

As more wells are drilled and analyzed, more information will be obtained which will characterize the groundwater hydrology. All drilling data should be collated and synthesized so managers can better understand, monitor, and predict changes in the system. Better geologic data will yield better information on groundwater recharge, storage, and flow. These data could be used to simulate the effect of geothermal development on the local hydrology. A simplified model of the hydrothermal flow system of Long Valley caldera was constructed by Sorey et a1. (1978). The results from the model explain the general relation between heat flow and depth and duration of fluid flow, as well as the effective hydraulic characteristics of the hydrothermal reservoir.

It is important to monitor the local variations of the hot springs before, during, and after these tests. The data should include: piezometric maps, variation of spring temperatures with respect to tine, and the chemical composition of the major springs and streams. Investigation over a period of time may disclose that sources and proportions of mixing of waters can be determined from water chemistry data and water temperature measurements.

Water Chemistry

Water chemistry of the area can be assessed by changes in the mass balance of the region. This has been done by Eccles (1976). He used a salinity seepage survey to analyze the sources of arsenic into Lake Crowley. Flow and concentration data taken at selected points of the major tributaries to Lake Crowley account for flow of water and chemical constituents passing each sampling site. For the reach of stream between the upstream point $x$, and the downstream point $y$, the flow gain or loss, $Q$, between the points is:

$$
\Delta Q_{x y}=Q_{y}-Q_{x} \text { (in vol/unit time) }
$$


The gain or loss in mass, $m$ of each chemical constituent is:

$$
\Delta m_{i}=Q_{y} c_{i y}-Q_{x} c_{i x}
$$

where $c$ is the concentration (mass/unit volume) of the constituent at the sampling site. The concentration of constituent $i$ in the water gained or lost in the reach is:

$$
C_{j}=\Delta m_{j} / \Delta Q_{x y}
$$

This type of analysis requires that the streamflow remains constant during the sampling periods and that the water samples taken are representative of the total flow at the sampling site. A mass balance method of this nature should be used to synthesize the basic water chemistry data being collected by the LADWP. If trace elements and isotope data in streams and wells were analyzed in this manner, our ability to predict and detect the temporal and spatial variations, as well as the comunication between geothermal fluids and groundwater, would be enhanced.

Ongoing monitoring programs can provide assurance of continuing high quality water for municipal and industrial use. Additional analysis of trace elements would improve efforts to detect changes due to the release of geothermal fluids. However, the present monitoring systems do not give the information which will allow us to predict changes induced by geothermal development or to understand the chemical transformations that occur in the natural environment. A California Department of Water Resources (1967) study indicated that 16\% more arsenic was entering Lake Crowley than was leaving it. The study attributed this imbalance to removal of arsenic by complex bio-and-physiochemical process, although there were no quantitative assessments of the rates at which these processes take place or the environmental factors that influence them. Studies are needed to determine the fate of toxic constituents, such as arsenic, which are not accounted for by routine monitoring.

Additional studies are needed to determine the tolerances of each beneficial use. We must establish the range of temperatures that the fish in Hatchery Springs can tolerate and still maintain the present high levels of productivity. Could man selectively inject degraded geothermial fluids and still maintain the same productivity?

Analysis of Available Data

It is evident that significant data have been collected by various agencies. Typically, data are collected to meet specific information needs. For instance, the Los Angeles Department of Water and Power has collected much information on the quality and quantity of surface runoff in order to predict the amount and quality of water needed for municipal and industrial use. Data which are collected by one agency need to be synthesized to help establish baseline data which all agencies can readily use.

Areas which are most likely to be developed, such as the resurgent dome in the Long Valley caldera, need much more extensive hydrologic data than the rest of the KGRA. This would include the monitoring of streams and springs before and during development to establish baseline data and detect changes. In the Long Valley area, Hot Creek, Little Hot Creek, Hot Creek Fish Hatchery Springs, and 
Table 7

SUMMARY OF WATER QUALITY DATA GAPS

I. Need for Better Hydrologic Data

A. Development of a strategy for obtaining hydrologic data over the entire basin for a significant length of time

1. Hydraulic continuity and interconnection of aquifers

a. Pumping tests

b. Piezometric maps

2. Precipitation measurements

3. Test drilling and well logging

4. Temperature measurements on wells and springs at different depths and times

B. Pre- and post-development studies

1. Monitoring of streams

a. Flow and chemical measurements

b. Perform a mass-balance analysis to determine spatial and temporal variations

2. Determination of direction and quality of underflows

II. Additional Water Needed for Geothermal Electricity Production

A. Amount depends upon the method of cooling and quality of cooling water

B. Water budget must be established if local waters are to be used for cooling

III. Effect of Development on Hot Springs

A. Monitor local variations of the hot springs

1. Piezometric maps

2. Temperature data

3. Chemical composition of hot springs water

B. The effect of geothermal deep drilling on the local streams and hot springs could be evaluated by:

1. Pumping tests on a deep well with perhaps three to five additional observation wells

2. Performing a numerical simulation model on the data

IV. Effect of Extraction of Cooling Waters and Geothermal Waters on Surface Hydrology 
the Owens River would require monitoring. The California Department of Fish and Game does continuous temperature and occasional chemical monitoring of geothermal springs used by Hot Creek Fish Hatchery (e.g. see Lewis 1974).

Information is required for management to formulate conceptual models which will show how geothermal development will affect the water quality of the region. These models must be sensitive enough to define the acute and chronic impacts of development. It is easy to recognize immediate impacts, such as the effect of spilis from equipment breaks, but it is harder to determine the effects of impacts which are substantially delayed. Care must be taken to predict the secondary effect of geothermal energy production on the water quality of the KGRA.

\section{WATER QUALITY ISSUES}

On August 10-11, 1978, a workshop was held in Mamnoth Lakes, California to discuss the environmental issues concerning geothermal development in MonoLong Valley KGRA. In order to determine the key water quality issues concerning geothermal energy development, the water quality discussion group decided that it was necessary to evaluate the intended uses of water in the KGRA.

The dominant uses of water that flows through the KGRA are for municipal and industrial purposes, recreation, wildlife habitat, agriculture and grazing. The most desirable water for municipal and industrial use is water low in dissolved salts and especially low in heavy metals. The group decided that the municipal and industrial use cannot tolerate additional geothermal fluids, based on data from the California Department of Water Resources (1967). The fish hatchery production, fishing, and bathing in Hot Creek are the most important uses of water-related recreational activities in this KGRA. The actual flow of geothermal springs required to maintain adequate production in the fish hatchery is not known. Bathing activities in Hot Creek could tolerate wider variations in hot spring temperatures than now occur, but the water quality discussion group felt that Hot Creek is a valuable resource which should be preserved. Based on these intended uses, the water quality discussion group developed a list of major water issues (Table 8).

Two kinds of geothermal energy development have been proposed for Mono-Long Valley KGRA: space heating and electric power generation (see Chapter 2). Members of the water quality group felt that the major difference in the water quality impacts encountered by space heating and electric power generation is due to the scale of development, which will influence the secondary effects. Space heating will initially produce the same water quality impacts as electric power generation. The exploratory and development phases will be the same, just on a smaller scale. The water quality discussion group decided that limited exploration is necessary to determine the impact of development on the water resources of the KGRA. However, the effect of drilling and pumping of deep wells must be assessed to determine its effect on the hydrology of the region before additional development is allowed.

Geothermal energy development may affect water resources in three major ways. It can compete for local water supplies, contaminate surface and groundwaters, and affect the local hydrology. All of these problems are of greater concern 
Table 8

\section{MAJOR WATER QUALITY ISSUES}

(1) The comunication between groundwater and geothermal water. Will geothermal fluid extraction or reinjection contaminate the groundwater reservoirs or the surface water bodies which are used for municipal purposes. About $40 \%$ of the water supply for the City of Los Angeles flows through the KGRA.

(2) Is there enough additional water available for geothermal energy production needs. Nearly all surface waters in the KGRA are used locally or exported to the City of Los Angeles. The availability of ground water is undetermined. Amounts of additional water needed for geothermal development, if any, will depend upon the technology which is utilized.

(3) Are mitigation measures adequate to ensure that beneficial water uses are protected, even if an accidental spill or blow out occurs. What would happen to the quality of water in Lake Crowley. under the worst situation.

(4) What will be the effect of geothermal fluid extraction on Hot Creek Fish Hatchery Springs and Hot Creek itself.

in a hot water-dominated resource such as Long Valley, as compared to a vapor-dominated resource. Since enthalpy of water is lower in hot water fields than for water in the vapor state, much greater quantities of geothermal fluid must be brought to the surface and disposed for each kilowatthour of electricity that is produced. For example, at Wairekei, New Zealand, over 20 million gallons of geothermal fluids are disposed of daily for each $100 \mathrm{Mw}$ of generating capacity (U.S. Environmental Protection Agency 1977). This compares to 1 million gallons per day which are disposed of at The Geysers (California), a vapor dominated resource, for each 100 Mw of electricity generated (Berman 1975).

Local water supplies may be affected if additional freshwater supplies are required for cooling towers and drilling. The amount of water needed for geothermal energy production depends upon the type of development. Space heating would require very little freshwater, whereas the amount of additional water required for electricity generation depends upon the method of cooling utilized and the quality of cooling water. A water budget must be established if local groundwater is to be used for cooling. Overdraft of groundwater reservoirs for geothermal development is of concern. Small perched water tables may become depleted and not recharged. This can only be determined by good understanding of the hydrology of the area. The amount of recharge and outflow needs to be established. This can be done by interpreting precipitation and well data. The direction and quantity of groundwater flow needs to be established.

The quality of the geothermal fluid in a hot water-dominated resource is potentially toxic and must be prevented from entering the surface or ground- 
water. The Lahontan Regional Water Quality Control Board precludes disposal of wastewater into any surface water and will not allow reinjection into any groundwater reservoir if the beneficial uses of the subsurface water cannot be protected. Even though reinjection is the most desirable method of wastewater disposal, one must guard against accidental spills and blow-outs. These wastewaters, if accidentally released into the natural environment, could alter the temperature and composition of local surface and groundwaters.

Reinjection or extraction of geothermal fluids could alter the hydrology of the KGRA. Withdrawal of geothermal fluid may cause pressure declines in the hot water reservoir which, in turn, may reduce the natural discharge of geothermal fluids into surface and groundwaters. In the case of Long Valley, such an occurrence could reduce the temperature of the water diverted to Hot Creek Fish Hatchery, which is near optimum for production of trout. Also, it could reduce the temperature of local accretions of geothermal waters to Hot Creek, a popular bathing site. However, reducing the natural discharge of geothermal fluid would likewise decrease the loading of arsenic and other potentially toxic elements entering Lake Crowley reservoir. Geothermal development could potentially affect the direction and quantity of underground flow, mixing of geothermal fluids and surface waters, flow of the hot springs, composition, and temperature of the waters entering the fish hatchery.

Geothermal energy production may bring changes in the natural hydrologic and water quality regime. The immediate effects, as well. as the long range changes induced by geothermal energy, must be assessed. Water quality management will consist of measures to prevent geothermal waters from entering surface and groundwaters. Indeed, if one could el iminate all contamination of the natural waters, there would be no concern. But, accidents do happen, despite all of the laws enacted and money spent. However, accidents have initiated improved mitigation measures. For example, retaining barriers, which are designed to contain any accidental spills from power plants, have become standard practice. Data must be obtained that will allow determination of the probability and extent of a spill. The effects of climate and hydrologic events on the effectiveness of mitigation measures must al so be assessed.

A better understanding of the hydrology, water quality, and tolerance of each beneficial use in the KGRA would enhance efforts to predict the aforementioned impacts. In order to assess changes in the environment, data must be obtained and synthesized, which will delineate the temporal and spatial variations in the natural environment, both before and during geothermal energy production.

The only way to determine any comunication between groundwater and geothermal water is through well tests. The drilling and analysis of observation wells will delineate the source of the cold groundwater and geothermal water. If temperature, water chemistry, and piezometric elevations were monitored for a significant length of time, the interrelation between the geothermal springs and the cold-groundwater system could be obtained. A mass balance analysis could be used to determine and predict how hydrologic events such as precipitation would affect the local variations in the spring discharge. A production well must be drilled, pumped, and observed to determine the effect of extracting geothermal fluid on the groundwater and hot water system.

The prevention of spills and discharges of brines during testing and in well casings appears to be adequately controlled by the California Regional Water 
Quality Control Board, the California Division of 011 and Gas, and the U.S. Geologic Survey. A worst case analysis should be performed to determine the acute effect of a major spill on the water quality of Lake Crowley. This should be done under many different climatic conditions.

The effect of geothermal fluid extraction on the Hot Creek Fish Hatchery Springs can be determined in the same manner as one would detect changes in the communication between the cold groundwater system and the geothermal system as previousiy described. Mitigation of any adverse temperature effects at the Fish Hatchery might be accomplished by selective addition of geothermal water from production wells to maintain optimum breeding temperatures. This could only be done if it did not violate environmental protection laws established by the Lahontan Regional Water Quality Control Board.

\section{POTENTIAL BARRIERS TO GEOTHERMAL ENERGY DEVELOPMENT}

Members of the water quality discussion group felt that the large quantities of potentially toxic geothermal fluid that are extracted and reinjected may present barriers to geothermal energy development, since:

(1) The release of any geothermal fluid into surface or groundwaters may exceed the concentration of arsenic or heavy metals allowed in a municipal water supply.

(2) Development of the hot resource for electricity generation may require additional freshwater supplies for cooling. These supplies may not exist or be available for exploitation.

\section{CONCLUSIONS}

I. Much information is already being collected by various agencies. Water quality and quantity are monitored routinely by the Los Angeles Department of Water and Power and to a limited extent by the California Department of Water Resources.

II. Compositions of waters used for municipal and industrial processes are adequately monitored to determine changes in municipal and industrial waters.

III. More extensive studies of the shallow aquifers near hot springs as well as long term measurements of hot spring discharges would enhance efforts to predict and detect changes in Hot Creek and other hot spring areas in the KGRA.

IV. Data must be gathered to determine the amount of water needed and available for geothermal energy production.

V. Basic hydrological studies in the Mono Lake Basin are needed before development occurs there.

VI. Deep drilling and pumping tests are needed to evaluate the effect of development on local hot springs. Well logs, aquifer constituents, 
and well field pressures can be measured during exploration by the industry. All available baseline data and data on energy producing aquifers need to be synthesized into predictive models before and during exploration and development. This is necessary for adequate monitoring of hot spring activity and control of development.

\section{ACKNOWLEDGMENTS}

We thank Ray Krone and Gerald Orlob (co-principal investigators of the study), for their discussion of the material, suggestions, and critical review of the manuscript. Comments on the manuscript were also received from the following individua1s: Barry Boudreau and associates (U.S. Geological Survey, Menlo Park), Gerald Gewe (Los Angeles Department of Hater and Power), Steve Lipshie (University of California, Los Angeles), Charles McDonald (U.S. Forest Service), Frank 0lmsted (U.S. Geological Survey, Menlo Park), Robert Sandy (Mono County Planning Department), Carl Strojan (University of California, Los Angeles), James Vantine (Union $0 i 1$ Company), James Wickser (Los Angeles Department of Water and Power), and Syd Willard (California Energy Commission).

The following individuals participated in the discussions of the water quality section of the workshop on August 10-11, 1978: Ted Abresch, Paul DeDecker, Ali Ghorbanzadeh, Ray Krone, Robert Mariner, Diane Mawby, Kenneth Pimentel, and John Sakaguchi. Affiliations are given in Appendix iv to the report. Joint discussions were also held with members of the geology section.

We thank A. H. Lachenbruch and R. E. Lewis for permission to use copyrighted materiais. 
Bailey, R. A., G. B. Dalrymple, and M. A. Lanphere 1976. Volcanism, structure, and geochronology of the Long Valley caldera, Mono County, California. J. Geophys. Res. 81:725-744.

Baas, J., F. D. Westerdah1 and R. L. Perrine (eds.). 1976.- Non-point source water quality monitoring, Inyo National Forest, 1975. California Water Resources Center Contribution No. 156.

Berman, E. R. 1975. Geothermal energy. Noyes Data Corporation, Park Ridge, N.J.

California Department of Water Resources. 1964. Ground water occurrence and quality, Lahontan region. Bulletin no. 106-1.

California Department of Water Resources - 1967. Investigation of geothermal waters in the Long Valley area, Mono County.

California Department of Water Resources, Southern District. 1973. Mammoth Basin water resources environmental study (final report), 70 p. +11 App.

California Department of Water Resources. 1977. Hydrologic data: 1975. Volume V: southern California. Department of Water Resources Bulletin No. 130-75.

Eccles, L. A. 1976. Sources of arsenic in streams tributary to Lake Crowley, California. U.S. Geol. Survey, Water-Resources Investigations 76-36, 39 p.

Hermann, C. and F. R. McGregor (eds.). 1973. Water quality and recreation in the Mammoth Lakes Sierra. Environmental Science and Engineering Program, University of California, Los Angeles, $166 \mathrm{p}$.

Lachenbruch, A. H., M. L. Sorey, R. E. Lewis and J. H. Sass. 1976. The near-surface hydrothermal regime of Long Valley caldera. J. Geophy. Res. $81: 763-768$.

Lee, K. 1969. Quaternary stratigraphy and geologic history of Mono Basin, eastern California. Ph.D. Thesis, Stanford University, 196 p.

Lewis, R. E. 1974. Data on wells, springs, and thermal springs in Long Valley, Mono County, California. U.S. Geol. Survey open-file report, 52 p.

Los Angeles Department of Water and Power. n.d. Los Angeles water rights in the Mono Basin and the impact of the Department's operations on Mono Lake.

Lyon R. J. P. and L. Lee. 1968. Infrared exploration for coastal and shoreline springs. Stanford RSL Technical Report 68-1. 
Mariner, R. H. and L. M. Willey. 1976. Geochemistry of thermal waters in Long Valley, Mono County. California. J. Geophy. Res. 81:792-800.

Mono Lake Committee of the Santa Monica Bay Audubon Society. 1978. Mono Lake: Its uncertain future. Oakland, Calif., P.0. Box 2764, 17 P.

Monoplan Associates. 1973. Monoplan Phase 2: Environmental background reports. Monopian Associates, South Pasadena, Calif.

Sorey, M. L. 1976. Potential effects of geothermal development on springs at the Hot Creek Fish Hatchery in Long Valley, Mono County, California. U.S. Geol. Survey open-file report $75-637,13 \mathrm{p}$.

Sorey, M. L. and R. E. Lewis. 1976. Convective heat flow from hot springs in the Long Valley caldera, Mono County, California. J. Geophy. Res. $81: 785-791$.

Sorey, M. L., R. E. Lewis and F. H. 01msted. 1978. The hydrothermal system of Long Valley caldera, Californta. U.S. Geol. Survey Prof. Paper 1044-A, 60 p.

State Water Resources Control Board. 1974. Abstract report on water quality control plan for the South Lahontan Basin 6B. California Regional Water Quality Control Board--Lahontan Region, South Lake Tahoe, Calif., $67 \mathrm{p}$.

U.S. Environmental Protection Agency. 1977. Western energy resources and the environment. Report EPA-600/9-77-010.

Willey, L. M., J. R. O'Neil and J. B. Rapp. 1974. Chemistry of thermal waters in Long Valley, Mono County, California. U.S. Geol. Survey open-file report.

Winkler, D. W. (ed.). 1977. An ecological study of Mono Lake, California. Institute of Ecology Publication No. 12, University of California, Davis. 
APPENDIX A: DATA SOURCES

This section will identify the data from the major reports containing hydrologic and water quality information for the Mono-Long Valley KGRA.

1. Baas, J., F. D. Westerdahl and R. L. Perrine (eds.). 1976. Non-Point Source Water Quality Monitoring, Inyo National Forest, 1975.

This report presents the results of a study by the Environmental Science and Engineering Program at UCLA on the impact of non-point sources on water quality in wilderness and recreational areas within Inyo National Forest. Thirty-four sites were sampled during the sumer and fall of 1975, but only three of these (Hot Creek, Sherwin Lakes and Horseshoe Lake) were in the KGRA. Physical measurements included air and water temperature, dissolved oxygen, pH, and TDS. Chemical analyses included sulfates, nitrogen, chloride and phosphates. Bacteriological observations were also made.

2. California Department of Water Resources. 1964. Groundwater Occurrence and Quality, Lahontan Region.

This report provides a general description of the geology, water supply, water quality, and utilization of the groundwater resources of the Mono and Long Valley groundwater basins. Tables are included which describe the chemical characteristics of the groundwater and whether the water is suitable for irrigation and domestic use.

3. California Department of Water Resources. 1967. Investigation of Geotherma? Waters in the Long Valley Area, Mono County.

This investigation describes the hydrology, geology, and geochemistry of Long Valley. The report concluded that Hot creek is the largest source of natural degradation of water quality in the area. Hot Creek contributes 11,500 acre $\mathrm{ft} / \mathrm{yr}$ of mineralized water with TDS $1500 \mathrm{ppm}$, (FI) $\sim 2.1-21 \mathrm{ppm},(\mathrm{B}) \sim 0.9$ - $2.3 \mathrm{ppm}$, (As) $-1.6-3 \mathrm{ppm}$, and significant concentrations of the trace elements strontium, iron, manganese, and germanium into Lake crowley. The report tabulates the chemical constituents, electrical conductivity, temperature, and $\mathrm{pH}$ of the major streams, wells, and springs in Long Valley. Some of the data included in the report are: (a) monthly measurements from two state wells $(33 / 28 E-33 \mathrm{P} 1)$ and (3S/28E-34 R1) for the years 1963, 1964, and 1966 ; (b) periodic measurements from a number of springs and wells; (c) monthly chemical analyses for Grant Lake, Hot Creek at County Road, and Crowley Lake from 1953-1967; and (d) selected spectrographic analyses of trace. elements of major streams and lakes from 1957-1966.

4. California Department of Water Resources, Southern District. 1973. Mammoth Basin Water Resources Environmental Study (Final Report).

The study describes the hydrology, water quality, and geology of the southwest portion of the KGRA, Mammoth Basin. The study tabulates discharge (runoff) of streams and lake volumes, and depth to the water table for the basin. A periodic mineral analysis is included for Hot Creek at County Road and Mammoth Creek at 01d Highway 395 from 1933-1971 and the major water bodies in the basin, Lake Mary,"Lake George, Lake Mamie, and Twin Lakes. 
5. California Department of Water Resources. 1977. Hydrologic Data: 1975.

Included in this extensive report are mineral and nutrient analyses from numerous sites in the Long Valley area. Data were collected in 1975 by the Department of Water Resources and the Lahontan Regional Water Quality Control Board.

6. Eccles, L. A. 1976. Sources of Arsenic in Streams Tributary to Lake Crowley, California.

This study inventoried arsenic sources which flow into Lake Crowley. An analysis of about 50 water samples from 13 sources and results from a detailed investigation of Hot Creek are included. Seepage-salinity surveys were conducted six times to determine the volume and chemical composition of water and constituents gained or lost along several reaches of Hot Creek.

7. Hermann, C. and F. R. McGregor (eds.). 1973. Water Quality and Recreation in the Mammoth Lakes Sierra.

This report presents the results of a study conducted during the sunmer of 1972 by graduate students and faculty from the Environmental Science and Engineering Program at UCLA. The study focused on the relationships between recreation and water quality in the Sierra Nevada. Chemical and microbiological data were collected from sites in the Shadow Creek-San Joaquin River and Manmoth Creek drainages, and recommendations for future water quality control policies and monitoring programs were made. All sampling locations were in mountainous areas unlikely to be affected by geothermal development.

8. Lachenbruch, A. H., M. L. Sorey, R. E. Lewis, and J. H. Sass. 1976. The Near-Surface Hydrothermal Regime of Long Valley Caldera.

Temperature measurements were taken from 29 shallow holes which indicate the influence of the hydrologic system. The shallow thermal observations help define the areas of recharge, discharge, where the shallow system is relatively impermeable, and areas of subsurface discharge of hot or warm groundwater.

9. Lamont-Doherty Geochemical Studies of Mono Lake.

The Lamont-Doherty Geological Observatory of Columbia University has been conducting long-term geochemical studies of closed basin lakes in the west-one of which is Mono Lake. Principal investigators for this basic research, originally funded by the Atomic Energy Commission, are Wallace S. Broecker and David L. Thurber. Much of the work relates to radionuclide behavior in the various lakes. Pertinent reports include the following:

Thurber, D. L. and W. S. Broecker. 1969. The behavior of radiocarbon in surface waters of the Great Basin. Report CU-2493-10 (App.A), 40 p.

Broecker, W. S. 1969. $\mathrm{Rn}^{222}$ to $\mathrm{Ra}^{226}$ ratios in closed basin lakes. Report CU-2493-10 (App. B), 4 p. 
Simpson, H. J. 1969. Lake Tahoe fallout study. Report CU-2493-10 (App. D), $28 \mathrm{p}$.

Broeker, W. S. and D. L. Thurber. 1970. Geochemical studies of continental waters, Report CU-2493-11, $282 \mathrm{p}$.

10. Lewis, R. E., 1974. Data on Wells, Springs, and Thermal Springs in Long Valley, Mono County, Cal ifornia.

The report includes tabulation of recent and historical data from wells, test wells, springs, and thermal springs. Included in these data are water-level measurements, flow rates, water temperatures, and some chemical analyses. Temperature gradients and bottom hole temperatures were made in selected wells. This is the most complete published listing of groundwater data for Long Valley.

11. Lyon, R. J. P. and K. Lee. 1968. Infrared Exploration for Coastal and Shorel ine Springs.

The geology, groundwater, chemistry, and infrared scanning measurements of Mono Lake were reported. The infrared imagery was able to detect the difference between the springs and lake when there was a temperature difference of less than $1.5^{\circ} \mathrm{C}$ if the flow rate was $12 \mathrm{gpm}$.

12. Los Angeles Department of Water and Power. n.d. Los Angeles Water Rights and the Impact of the Department's Operations on Mono Lake.

The report discusses the impacts of the City of Los Angeles' diversions on the level of Mono Lake. Due to the diversions, the lake has declined at a rate of 1.5 to $2.0 \mathrm{ft}(0.5-0.6 \mathrm{~m})$ per year since 1950 . If this continues, Negit Island will be bridged to the mainland, and the avian population on the island will be subject to predation. Mitigation measures were analyzed to prevent this effect.

13. Los Angeles Department of Water and Power (unpublished data).

14. Los Angeles Department of Water and Power. 1976. Final Environmental Impact Report on Increased Pumping of the Owens Valley Groundwater Basin.

This report contains information pertaining to the Department's efforts to increase groundwater pumping from the Owens Valley region. Much information is contained in the report, but most of it pertains to areas south of the KGRA.

15. Mariner, R. H. and L. M. Willey. 1976. Geochemistry of Thermal Waters in Long Valley, Mono County, California.

Geothermally important constituents including silica, principal cations, gas composition, and isotopic ratios of oxygen and hydrogen for the major hot springs in Long Valley were analyzed. The chloride concentrations, spring temperatures, and isotopic compositions indicate mixing of thermal and freshwaters in the Long Valley area. Some of the spring temperatures near Big Alkali Lake may be controlled by conductive cooling. 
16. Sorey, M. L. 1976. Potential Effects of Geothermal Development on Springs at the Hot Creek. Fish Hatchery in Long Valley, Mono County, California.

This paper describes the potential effects of geothermal development on the Hot Creek Fish Hatchery. Geothermal development may cause pressure declines in the hot water reservoir in the Long Valley caldera, which could el iminate the hot water component in the Hatchery Springs. Without the hot water component, the composite Hot Spring temperature could be lowered from $14.4^{\circ} \mathrm{C}$ to $11^{\circ} \mathrm{C}$. Such a temperature drop could decrease productivity in the hatchery.

17. Sorey, M. L. and R. E. Lewis. 1976. Convective Heat flow from Hot Springs in the Long Valley Caldera, Mono County, California.

Geochemical mixing models were used to estimate the heat discharged from the hot spring water in Long Valley, California. The effects of heat loss by conductive cooling, mixing, and boiling are quantified for the springs in Hot Creek Gorge.

18. Sorey, M. L., R. E. Lewis, and F. H. Omsted. 1978. The Hydrothermal System of Long Valley Caldera, California.

The results of previous geologic, geophysical, geochemical, and hydrologic investigations have been synthesized in this report to develop a generalized conceptual and mathematical model which describes the gross features of heat and fluid flow in the hydrothermal system of the Long Valley caldera.

19. State Water Resources Control Board. 1974. Abstract Report on Water Quality Control Plan for the South Lahontan Basin 6B.

This abstract report summarizes the comprehensive water quality control plan for the South Lahontan Basin 6B which was developed by the State of California.

20. Willey, L. M., J. R. O'Neil, and J. B. Rapp. 1974. Chemistry of Thermal Waters in Long Valley, Mono County, California.

The study reported chemical analyses on groundwaters (one grab sample) at 10 locations in Long Valley. Subsurface temperatures were calculated from those chemical measurements by using the computer program SOLMNEQ developed by $Y$. K. Kharaba.

21. Winkler, D. W. (ed.). 1977. An Ecological Study of Mono Lake, California.

The report includes the geology, geologic history, the geologic processes, and the historic fluctuation of Mono Lake. A water budget of Mono Lake was developed. It estimated the inflows from rainfall, streamflow, and groundwater flow, and outflow by evaporation from Mono Basin which is a closed basin with no seepage loss. The report provided a general description of the water table gradient and permeability of the substrata in the Mono Lake Basin. A hydrologic model was developed to demonstrate the effects of water diversion on Mono Lake. 


\section{Chapter 5}

\section{AIR QUALITY OVERVIEW}

Charles R. Molenkamp

Lawrence Livermore Laboratory

University of California 
TABLE OF CONTENTS

INTRODUCTION ....................... 132

KEY AIR QUALITY ISSUES .................. 133

DATA REQUIREMENTS ................... 134

Source Data ..................... 134

Meteorological Data................. 135

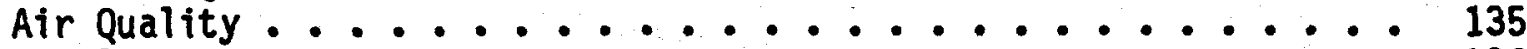

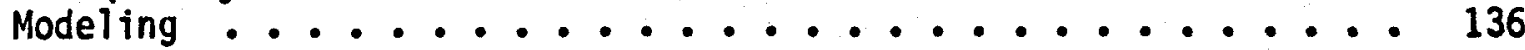

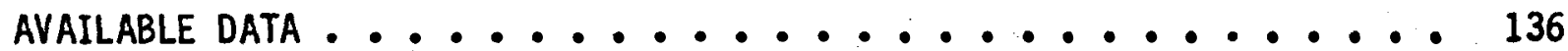

Source Data .......................... 136

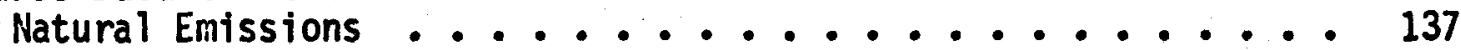

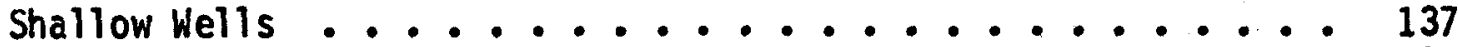

Deep Wells ................... 139

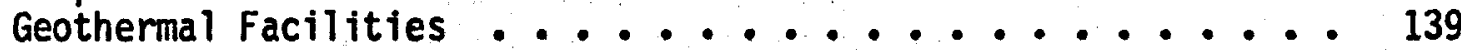

Meteorological Data .................. 139

Climate Data ........................... 139

Surface Winds ................... 140

Winds Aloft ........................... 140

Temperature Structure ................ 140

Visibility, Fog, Clouds ............... 142

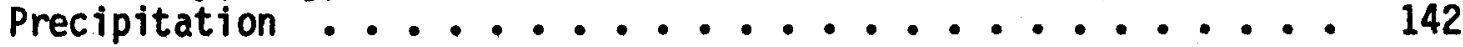

Air Quality Data ................. 142

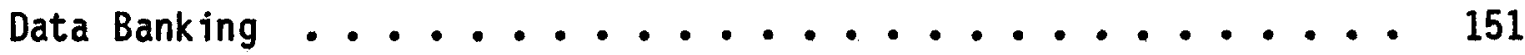

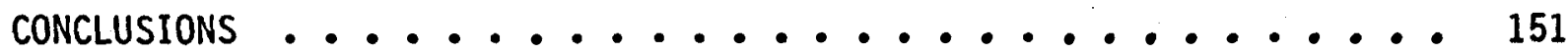

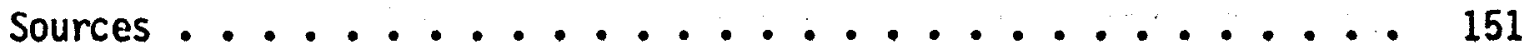

Meteorological Data ................... 154

Air Quality Data ................. 154

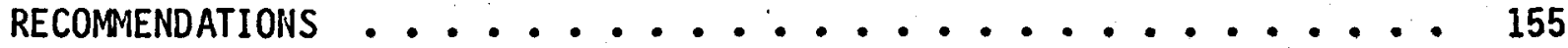

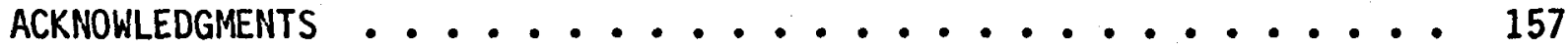

REFERENCES CITED ........................ 158 
1. Potential Air Quality Issues ......................... 133

2. Chemical Constituents of Fluids From Casa Diablo

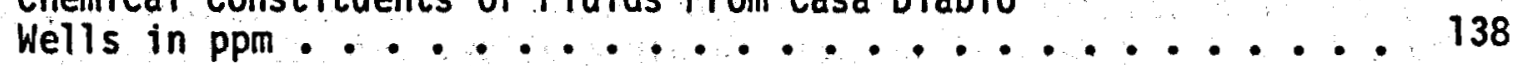

3. Ambient Air Sampling Data .................. 143

4. Ambient Hydrogen Sulfide Analyses ............ 150

5. Summary of Total Suspended Particulate Levels, JuneJuly $1972 \ldots \ldots 152$

6. Summary of Total Suspended Particulates, October 1972June 1973

\section{LIST OF FIGURES}

1. Natural Steam Emissions From a Fumarole Near Hot Creek Fish Hatchery Being Trapped by an Atmospheric Inversion .... 141

2. Locations of Ambient Air Monitoring Stations ........ 149 


\section{INTRODUCTION}

The Mono-Long Valley Known Geothermal Resources Area (KGRA) is considered a favorable site for development of geothermal resources (Muffler 1979). Utilization of geothermal resources in other places has led to changes in air quality, and there are concerns that development in the Mono-Long Valley KGRA will lead to similar changes. This chapter identifies key air quality issues associated with development of the geothermal resource, summarizes data available to assess potential changes in air quality, defines additional data that are needed, and recommends measurement programs and research for acquiring these data.

Several unique characteristics of the Mono-Long Valley KGRA have significant influences on evaluating or determining acceptable air quality changes. First, it is one of the most scenic regions in the state. The southwest portion particularly, which is the most promising area for geothermal development, has extremely high outdoor recreational value. Aesthetic changes such as visible structures, cooling towers, plumes, or minor reductions in visibility, that would be readily accepted in other places may be considered intolerable in this area. Second, the elevation of the entire KGRA is above $6,400 \mathrm{ft}$ MSL. In winter particularly, the area is subject to very low temperatures, so that even small releases of water vapor could lead to significant enhancement of cloudiness and fog. Finally, there are several enclosed or nearly enclosed basins within the KGRA where very strong temperature inversions frequently occur. These conditions trap emitted pollutants where they may build up to high concentrations.

One of the characteristics of Mono-Long Valley KGRA is that it can be considered as two nearly independent regions: Mono Basin and Long Valley. The region is divided into northern and southern sections by the GTass Mountain Ridge-Bald Mountain highlands (Fig. 1, Chapter 3 ). Geothermal outcroppings occur near Casa Diablo at the intersection of highways 395 and 203 in Long Valley, and in Mono Basin in and around Mono Lake. These physical features of terrain and geothermal distribution allow the two parts of the KGRA to be considered separately.

Two types of geothermal resource utilization are being considered for the Long Valley portion of the KGRA: district space heating and electric power generation (see Chapter 2). Large differences in potential air quality impacts exist for these two types of development. Utilization of geothermal fluids in a district space heating system would have negligible impacts on air quality because geothermal fluids would not normally be emitted to the atmosphere in significant quantities. However, there would be increased suspension of particulates during construction, and major geothermal emissions would occur if there were a break in the system. A more common type of development is transformation of the energy stored in geothermal fluids into electricity. There are several methods for transforming energy from geothermal to electric, and each method has different emission characteristics. In some technologies (e.g. binary systems) the geothermal fluid is almost completely contained and reinjected. The major air quality concerns for such developments would be with water vapor emissions from cooling towers. Other methods, such as those used at The Geysers, permit large amounts of the geothermal fluid to be emitted into the atmosphere. For these systems one must assess the effects of 
emissions on potential receptors. Since planned development has not yet advanced to the stage where systems are designed, all types of development, including those that release geothermal fluids, must be considered as possibilities.

In addition to considering the different types of geothermal utilization, it is important to recognize several different components of development because each component has its associated potential air quality impacts. Site preparation usually involves major earth moving activities such as leveling, road building, and trenching. These activities are often major sources of dust suspension. Drilling of exploratory and production wells can lead to significant emissions of some components of the geothermal fluid. This phase of development is frequently accompanied by dust suspension and high noise levels. Well flow-testing and clean-out can produce similar impacts. Construction of geothermal transport systems and power plants can be accompanied by emissions of various types and dust suspensions. Operation of power plants would be the major continuing source of geothermal emissions either through stacks, vents or cooling towers--depending on the design of the plant. Power plant shut downs have led to significant emissions in other KGRA's and may have different characteristics than routine power plant emissions. The final phase of development is the closing down of wells and plants. This must be done in a way that prevents continuing air quality impacts.

\section{KEY AIR QUALITY ISSUES}

On August 10-11, 1978, a geothermal workshop on Mono-Long Valley KGRA was held at Mammoth Lakes, California (see Appendices III and IV). In the air quality section of that workshop key issues relating to air quality were discussed, and recomendations were made regarding additional research. This report depends heavily on the conclusions reached at that workshop. Key potential air quality issues from geothermal development in Mono-Long Valley KGRA are shown in Table 1.

\section{TABLE 1}

\section{POTENTIAL AIR QUALITY ISSUES}

1. Visibility degradation from increased particulate loading of the atmosphere.

2. Odor from increased ambient air concentrations of hydrogen sulfide $\left(\mathrm{H}_{2} \mathrm{~S}\right)$.

3. Increased ambient air concentrations of other non-condensible gases and chemical elements (e.g., ammonia $\left(\mathrm{NH}_{3}\right)$, methane $\left(\mathrm{CH}_{4}\right)$, mercury $(\mathrm{Hg})$, radon $(\mathrm{Rn})$, carbon dioxide $\left(\mathrm{CO}_{2}\right)$, arsenic $(A s)$, and boron $\left.(B)\right)$.

4. Increased cloudiness, fog, precipitation, and highway icing from water vapor emissions, particularly in winter.

The KGRA is heavily used for outdoor recreation, both in summer and winter. Because this use depends in part on the excellent visibility and air quality presently existing, there is great concern that construction and development of a geothermal industry in Mono-Long Valley KGRA will have an adverse impact 
on this land use. Construction activities are frequently large sources of airborne dust. Because of the very dry conditions and sparse vegetation existing in this area, the soil is particularly susceptible to this type of disturbance. Emitted hydrogen sulfide has the potential to be transformed into sulfate particles in the atmosphere, and such particles are usually of sizes that are particularly effective at reducing visibility. However, the transformation of $\mathrm{H}_{2} \mathrm{~S}$ into sulfate particles will most likely be too slow in the dry atmosphere of Mono-Long Valley to produce a major effect.

Hydrogen sulfide from geothermal wells and power plants also has the potential of being an odor nuisance in inhabited areas. Although most of the residences and visitor facilities are located in areas that are usually upwind of likely geothermal development areas, any detection of $\mathrm{H}_{2} \mathrm{~S}$ odor would be considered a major adverse impact.

Emissions of other substances (e.g. heavy metals) have the potential for adversely affecting nearby flora and fauna, either by increasing ambient air concentrations or by direct deposition.

Emissions of large amounts of water vapor can result in increased fog and precipitation, highway icing, and cloudiness--particularly during the winter. While increases in precipitation might be considered beneficial, all these effects and changes should be estimated quantitatively so that correct management decisions can be made concerning geothermal development.

\section{DATA REQUIREMENTS}

Assessment of the potential geothermal impacts on air quality depends on adequate data and suitable models. Data in the following categories are needed: source, meteorological, and air quality. A model is a method of translating data on sources, meteorology and air quality into quantitative estimates of pollutant deposition, changes in ambient concentrations, and other relevant effects. For a model to be suitable it must be validated to the extent that significant confidence can be placed in its predictions.

In the remainder of this section we identify the types of data and models that are required to make assessments of potential impacts of geothermal development on air quality.

\section{A. Source Data}

The first step in establishing that a particular substance will produce an adverse impact is identification of that substance as an emitted material and then determination of its emission rate. Various physical and chemical properties of potential pollutants must also be determined. These properties include the effective height of release, early mixing and dispersion associated with release (e.g. dilution in cooling towers, and turbulence enhanced by fans or high velocity emission), and whether the pollutant is a gas or is emitted with drift droplets. All of these factors depend on the composition of the geothermal fluid and on specific designs of the various components of geothermal development. Similar requirements exist concerning emission of water vapor by geothermal operations. 
For assessment of impacts associated with dust suspension by construction and well drilling, data are required on the size distribution, suspension, and optical properties of dust particles for both natural and disturbed surface conditions.

\section{B. Meteorological Data}

The impacts of released materials depend on adequately assessing the effects of transport by wind and mixing with surrounding air, probably using atmospheric transport and diffusion models. These assessments are based on measurements of the flow fields and diffusive properties of the atmosphere for a suitable set of representative meteorological conditions. Because the terrain in Mono-Long Valley KGRA is complex, a relatively long and detailed record of wind data at the surface and throughout the lowest $2-3 \mathrm{~km}$ of the atmosphere is required to assess the most important potential pollutants.

Vertical temperature structure must also be measured because atmospheric stability has a large influence on vertical diffusion.

Data on relative humidity, precipitation, cloudiness, fog, and visibility are needed as baseline information to assess the effects of water vapor emissions and dust suspension.

C. Air Quality

Adverse impacts of geothermal development are manifest quantitatively by changes in ambient concentrations of emitted pollutants. To determine the effects of geothermal emissions on air quality it is necessary to measure the concentrations of pollutants before and after development. Relevant pollutants include $\mathrm{H}_{2} \mathrm{~S}, \mathrm{NH}_{3}, \mathrm{CH}_{4}, \mathrm{Hg}, \mathrm{As}, \mathrm{B}, \mathrm{Rn}$, and suspended particulates. To determine the effects of particulates on visibility, it is necessary to know not only the total mass suspended, but also the size distribution of particles and their optical properties. Knowledge of their composition, perhaps as a function of particle size, is needed to determine whether they contain any substances that are toxic or hazardous to man, or detrimental to flora and fauna.

Since there are fumaroles in the area, there are natural geothermal emissions of pollutants. In the immediate vicinity of fumaroles at Hot Creek, the odor of hydrogen sulfide can frequently be detected. In addition to these local geothermal sources of pollutants, materials are transported into the area by advection and are naturally emitted from the earth. Consequently, measurements of ambient concentrations of the substances listed above are needed before development begins to provide a baseline for comparison of post-development conditions.

After development begins, continued monitoring of ambient concentrations will be needed to assess impacts of geothermal emissions. Since development will occur in stages, there will be a continuing need to predict effects of geothermal emissions from new sources. For such predictions, atmospheric transport and diffusion models are most useful, but to have confidence in such models they must be validated. The monitoring of ambient concentrations and meteorological data provides the opportunity to test and validate such models. 
Tracer experiments have proven especially useful in developing an understanding of flow and transport characteristics, particularly in regions of complex terrain. Such experiments will be necessary as development proceeds in Mono-Long Valley KGRA. Conducting tracer experiments in conjunction with the development and validation of transport and diffusion models provides an effective technique for assessing the impacts of geothermal emissions.

One of the major potential changes in air quality in Mono-Long Valley KGRA is degradation of visibility, either because of dust suspension or increased cloudiness and fog. Baseline data are needed on current dust loading, fog frequency and characteristics, cloudiness, water vapor content and temperature. In addition, modification of the desert surface by construction can change the potential for dust suspension. Estimates of these changes as a function of wind are needed.

\section{Modeling}

Pre-development assessments of geothermal impacts are based on models of pollutant transport from the proposed source to various potential receptors. These models can range from simple conceptual models of air flow, to numerical models that calculate transport on the basis of equations describing the atmosphere simplified to various degrees, to physical models that use a small scale reproduction of the terrain and emissions in a wind tunnel. The main requirement on these models is that they be sufficiently accurate and reliable to specify downwind concentrations on the basis of available sources and meteorological data. Some of the major necessary or desirable features of such models are the following: (1) they must represent the three dimensional aspects of transport and diffusion in the very complex terrain of Mono-Long Valley KGRA, (2) they must include multiple emission sources, (3) they must incorporate plume dynamic of the release mechanism, and (4) they must be capable of simulating flow, during periods of strong thermal stability. For application to particulate emissions they must allow for deposition and resuspension. For assessment of fog and cloudiness they must represent condensation, evaporation, coagulation of droplets, and deposition or fallout of drops.

\section{AVAILABLE DATA}

\section{A. Source Data}

There are few data avilable on the gaseous components of geothermal fluids in Mono-Long Valley KGRA. This is due partly to the undeveloped state of the resource, the only operating geothermal facility being a small experimental space heating project at Wickes Lumber Company near Casa Diablo (see Chapter 2). This facility does not produce atmospheric emissions because it is a closed system. In an earlier development, Magma Power Company drilled nine wells at Casa Diablo from 1959-1962. These were relatively shallow wells ranging in depth from about 400-1000 feet (see Chapter 2). Large scale geothermal development will depend on production from much deeper wells than have been successfully drilled to date.

Most data on geothermal composition have been collected to determine the thermal characteristics and economic potential of the resource. The constitu- 
ents important for these considerations are not the same substances that lead to adverse air quality impacts.

\section{Natural Emissions}

There are numerous fumaroles and hot springs in Mono-Long Valley KGRA particularly along Hot Creek and Little Hot Creek. Ho comprehensive survey has been made of the composition of atmospheric emissions from these sources. Lewis (1974) compiled an extensive and thorough sumary of chemical analyses of fluids from wells and springs in Long Valley. Mariner and Willey (1976) measured the composition of the water from 7 hot springs, 2 cold springs, and 1 Casa Diablo geothermal well, primarily to estimate the temperature of the geothermal reservoir. of the potentially important air quality emissions, they measured concentrations for boron $(7-15 \mathrm{mg} / 1)$, arsenic $(0.3-2.2 \mathrm{mg} / 1)$, and hydrogen sulfide $(0.7-10 \mathrm{mg} / \mathrm{l})$ in fluids collected from the hot springs and well. The measured $\mathrm{H}_{2} \mathrm{~S}$ included only that in water, not what was emitted as a gas, which would be much larger. The odor of hydrogen sulfide is readily detectable in the vicinity of the hot springs.

D. Robertson and J. Evans (Battelle-Pacific Northwest Laboratories) measured trace consituents in several fumaroles and hot springs in Mono-Long Valley KGRA and presented these data at the geothermal workshop at Mammoth Lakes on August 10-11, 1978. The data they presented are summarized as follows: Radon concentrations are slightly higher than at The Geysers, where atmospheric emissions have negligible impacts. Boron was found at very low concentrations in steam condensate and at relatively high concentrations in geothermal brine and in Mono Lake. Arsenic concentrations were low in the stean condensate, but high in flashed brine. Because of the potential for increased arsenic concentrations in Lake Crowley, which is part of the Los Angeles water supply, release of geothermal fluids into surface waters is prohibited by the Lahontan Regional Water Quality Control Board (California Department of Water Resources 1967).

Plans are being made to sample waters and gases from geothermal springs in Long Valley as part of a study being conducted by Woods Hole Oceanographic Institution. Sampling in Long Valley is expected to begin in 1979 and will include analyses for argon, helium, neon, radon and xenon (personal communication between $T$. Torgersen and C. Strojan).

\section{Shallow Wells}

There have been only a few measurements of the concentrations of potential air pollutants at the Magma Energy, Inc. wells. Data presented by McNitt (1963) are given in Table 2. Note that these fluid samples were collected in different ways and that none of them included gases emitted as non-condensibles. The steam produced from Endogenous No. 4 contained $0.87 \%$ by weight non-condensible gas, which was $98.64 \%$ by weight $\mathrm{CO}_{2}$ and $1.36 \%$ by weight $\mathrm{H}_{2} \mathrm{~S}$. The steam thus contained 118 ppmw $\mathrm{H}_{2} \mathrm{~S}$, which compares with an average of 220 ppmw for steam produced at The Geysers. Additional analyses of well fluids, based on data presented by Lewis (1974), are shown in Chapter 2. 
TABLE 2

CHEMICAL CONSTITUENTS OF FLUIDS FROM CASA DIABLO WELLS IN PPM.

Endogenous
No. $1^{\mathrm{a}}$$\quad \begin{gathered}\text { Endogenous } \\ \text { No. } 1^{\mathrm{b}}\end{gathered}$

\begin{tabular}{ll}
$\begin{array}{c}\text { Endogenous } \\
\text { No. } 2^{\mathrm{a}}\end{array}$ & $\begin{array}{c}\text { Mammoth } \\
\text { No. } 1^{\mathrm{b}}\end{array}$ \\
\hline
\end{tabular}

Endogenous

No. $4^{C}$

Endogenous

$\begin{array}{rr}250 & 278 \\ & 2 \\ 380 & \text { trace } \\ 47 & 236 \\ & 62 \\ & 4 \\ & 5 \\ 276 & 2 \\ 61 & 60 \\ & 266 \\ & 108\end{array}$

8.86

7.5

256

292

30

trace

375

45

Li

Fe

Cl

$\ddot{\omega}$

$\mathrm{SO}_{4}$
$\mathrm{H}_{2} \mathrm{~S}$
$\mathrm{~F}$
$\mathrm{NH}_{3}$
$\mathrm{CO}$
$\mathrm{As}_{2}$
$\mathrm{pH}$

4

5

60

266

108

276

62

200

4

No. $4 d$

Source: McNitt (1963)

asample taken from wellhead after cooling. No flashing to steam.

bSample taken from wellhead immediately after flowing. Some water flashed to steam.

CWater sample taken during flow test.

dCondensate of steam sample taken during flow test.

247

71

3

4

49

301

124

308

32

0.3

11
227
96
14
20
0.1
180
0.2
6.5

2

11

0.5

205

4.9

5

\section{3}

8.0

0.2

5

0.8 


\section{Deep We.11s}

No deep well drilled in Mono-Long Valley KGRA has intersected a geothermal resource of commercial quality, therefore, no data are available on the composition of geothermal fluids that will be most important for any large scale development. Data from shallow wells and natural sources do not necessarily provide information on the deep reservoir, since the geothermal layers may have quite different and variable trace constituents.

\section{Geothermal Facilities}

Knowledge of the composition of the geothermal fluid input to a utilization facility is only the first step in estimating the emission rate and characteristics. Space heating will most likely use an entirely closed system where there are no atmospheric emissions. A variety of potential designs for geothermal power plants exist, each with its own emission characteristics. As development plans proceed it will be necessary to consider the processing of geothermal fluids and the relative emission rates of each plant type. For some power plant designs there are data available on the disposition of various consistuents of the geothermal fluid, but in most cases great uncertainty exists, and emission rates could not be reliably estimated even if the input composition were known.

\section{B. Meteorological Data}

There are few meteorological data for Mono-Long Valley KGRA. This is probably due to the low population density of the region, the only sizeable concentration of residents being at Mammoth Lakes Village.

1. Climate Data

The nearest National Weather Service climatological data station is in Bishop, approximately 25 miles southeast of the closest boundary of the KGRA and at an elevation of $4100 \mathrm{ft}, 2300 \mathrm{ft}$ lower than the lowest point in the KGRA, but still within a similar climatic zone.

The climate in the KGRA is largely controlled by terrain, particularly the Sierra Nevada to the west. Descriptions of the climate are given by the California Department of Water Resources (1967), James A. Roberts Assoc., Inc. (1973), Sasaki, Walker, Roberts, Inc. (1975), the Great Basin UAPCD (1976), and Peterson and Palmer (1977). They are based on data for Bishop, supplemented with scattered data for other sites, and interpreted according to the experiences and observations of the authors.

The major feature of the climate is its dryness, due largely to the rain shadow effect of the Sierra Nevada. Winds are generally oriented parallel to the mountain ranges, north-northwest to south-southeast, and can be strong at times. Skies are usually clear and visibility excellent, except for occasional dust storms associated with strong winds, and fogs associated with the trapping of moisture in enclosed basins when surface winds are light and strong low-level inversions form. 


\section{Surface Winds}

The most important meteorological variable affecting air quality is wind because wind transports pollutants from sources to receptors and disperses emitted substances in the atmosphere. There are no routine surface wind stations in Mono-Long Valley KGRA. Long term wind data are available only for the climatological station at Bishop.

Terrain has a dominant effect on air flow characteristics within the KGRA. Even synoptically forced flows are greatly modified by terrain features, and when the synoptic forcing is small the air flow is driven by local heating and cooling of the mountain surface. A discussion of typical flows under the various regimes is included in Peterson and Palmer (1977). These postulated flow fields are based as much on the personal experience of one of the authors (Palmer) as on measurements of winds in the area.

Essentially all climatological data for the geothermal area are summarized by Peterson and Palmer (1977). The major wind data include one year of measurements (1975-76) on the plateau just northeast of Hot Creek Fish Hatchery and six months (0ct. 57-Mar. 76) data in Little Antelope Valley. Data at these two sites were recorded at two levels, $5 \mathrm{~m}$ and $15 \mathrm{~m}$, and are summarized in deta11. Data were also collected on vertical winds and smoke tracer experiments. Wind measurements have also been made at U.S. Forest Service headquarters near Mammoth Lakes, at Lee Vining, and on Mammoth Mountain in winter. These wind data have not been analyzed. A 34-year record of average daily wind speed, but not direction, is available for Long Valley Dam at Lake Crowley.

\section{Winds Aloft}

Potential pollutants are emitted, transported, and dispersed primarily at levels above the surface, but within the boundary layer. Consequently, knowl edge of wind fields within a few $\mathrm{km}$ of the surface is required to assess impacts of pollutants.

The only above-surface wind data available for this region are those collected at the $15 \mathrm{~m}$ level by Palmer in Little Antelope Valley and near the Hot Creek Fish Hatchery.

\section{Temperature Structure}

A very important parameter governing the vertical dispersion of emitted pollutants is the vertical temperature structure of the atmosphere. Surface air temperature data are available for several sites in or near Mono-Long Valley KGRA. These include climatological data for Bishop, Gem Lake, and Long Valley Dam. Temperature has also been recorded in recent years at the $U$. $S$. Forest Service headquarters at Mammoth Lakes and on Mammoth Mountain in winter. The meteorological towers in Little Antelope Valley and near Hot Creek Fish Hatchery measured temperatures at $5 \mathrm{~m}$ and $15 \mathrm{~m}$ levels while they were in operation. These are the only data within the KGRA giving temperatures at two heights, and there are many cases, particularly in Little Antelope Valley, with very strong temperature inversions. 
From May 15-June 23, 1972 vertical temperature soundings were measured each morning by aircraft at Independence, 44 miles south of Bishop. These showed inversion tops at 500-1300 ft, and temperatures increasing with altitude by 0-15 F. Peterson and Palmer (1977) mention a few radiosonde measurements taken near Glass Mountain in Mono Valley during December 1965 and June 1966. These observations showed a strong ground-based inversion at night and a slightly elevated inversion during the day. Acoustic sounder data taken at Lake Crowley in January 1976 indicated no evidence of temperature inversions in the range of the instrument, which was 60-600 $\mathrm{m}$. Simultaneous visual observations of fog layers over the lake suggested that the inversion was below $60 \mathrm{~m}$. These data confirm the almost daily occurrence of nighttime temperature inversions that tend to be very strong and shallow. The existence of these inversions (Fig. 2) will have a major effect on buildup of emitted pollutants in enclosed basins unless the atmospheric emissions occur above the top of the inversion layer.

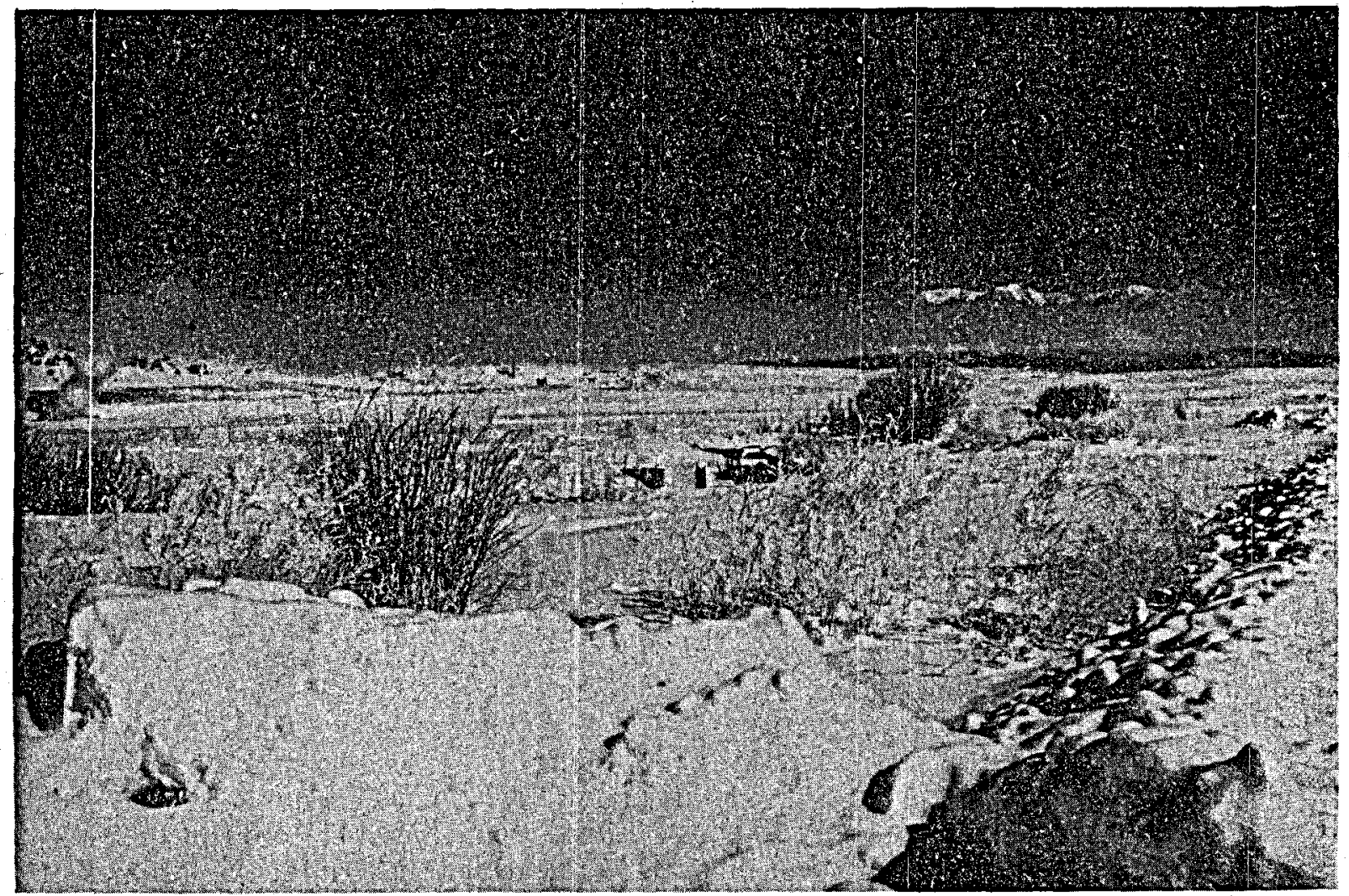

Fig. 1. Natural steam emissions from a geothermal fumarole (far left) near Hot Creek Fish Hatchery being trapped by an atmospheric inversion. 
5. Visibility, Fog, Clouds

Observations at Bishop are the only source of visibility and cloudiness data for Mono-Long Valley KGRA. These data are summarized by the Great Basin UAPCD (1976). The majority of observations were 70 miles, the maximum that can be reported. Poor visibilities (less than 10 miles) were associated with rain and wind blown dust. All observations of low visibility caused by dust were associated with winds of $11.5 \mathrm{mph}$ or higher.

There are no recorded data on fog frequency in this region. Fog is known to occur over Lake Crowley, and especially Mono Lake, when air stagnates and strong temperature inversions occur. These events occur most frequently in winter and may persist for days. The lowest parts of all the Great Basin Valleys, and particularly the enclosed basins are also subject to formation of fog, depending on moisture availability and temperature.

\section{Precipitation}

Precipitation is highly variable across the KGRA. Data are available for Gem Lake (in the mountains just west of June Lake), Long Valley Dam, Cain Ranch (adjacent to Grant Lake), Lake Mary, Rock Creek Lake ( 9 miles south of Long Valley Dam), and for Bishop. Summaries of these data are tabulated in James A. Roberts Assoc., Inc. (1973) and the Great Basin UAPCD (1976). Average annual precipitation in the KGRA ranges from about 56.5 in. at Mammoth Pass (California Department of Water Resources 1967) to about 7 in. in eastern Mono Basin (Winkler 1977, p. 17). Highest values occur at the Sierra crest and decrease rapidly towards the east. Approximately $2 / 3$ to $3 / 4$ of the annual. precipitation normally occurs during the winter as snow.

\section{Air Quality Data}

There has been no continuous monitoring of air quality for any atmospheric pollutants in Mono-Long Valley. The few available measurements have been intermittent and short term, and have been concerned mainly with pollutants normally associated with automobile emissions. All available air quality data are identified and surmarized in Peterson and Palmer (1977). Many of the same data are also presented by the Great Basin UAPCD (1976).

The main source of air quality data consists of measurements made by the California Air Resources Board in June-July, 1974 using a mobile van. This van measured ambient concentrations of sulfur dioxide, hydrocarbons, oxidants, nitrogen oxides, and carbon monoxide at Mammoth Lakes Village and in Bishop. Additional data include measurements of carbon monoxide by the California Department of Transportation in December 1974, ozone meausrements by the U.S. Forest Service in Mammoth Lakes from December 1975 to February 1976, spot samples of sulfur dioxide concentrations taken once a month during 1975 by Union Carbide at their tungsten mine and mill at Rovana (12 miles southeast of the KGRA), and spot measurements by the U.S. Geological Survey of sulfur dioxide, nitrogen oxides, and armonia during April and August 1974. Since none of these substances is normally emitted in significant amounts by geothermal operations, and since these data are all summarized by the Great Basin UAPCD (1976) and Peterson and Palmer (1977), they are not discussed further here. 
TABLE 3

\section{AMBIENT AIR SAMPLING DATA}

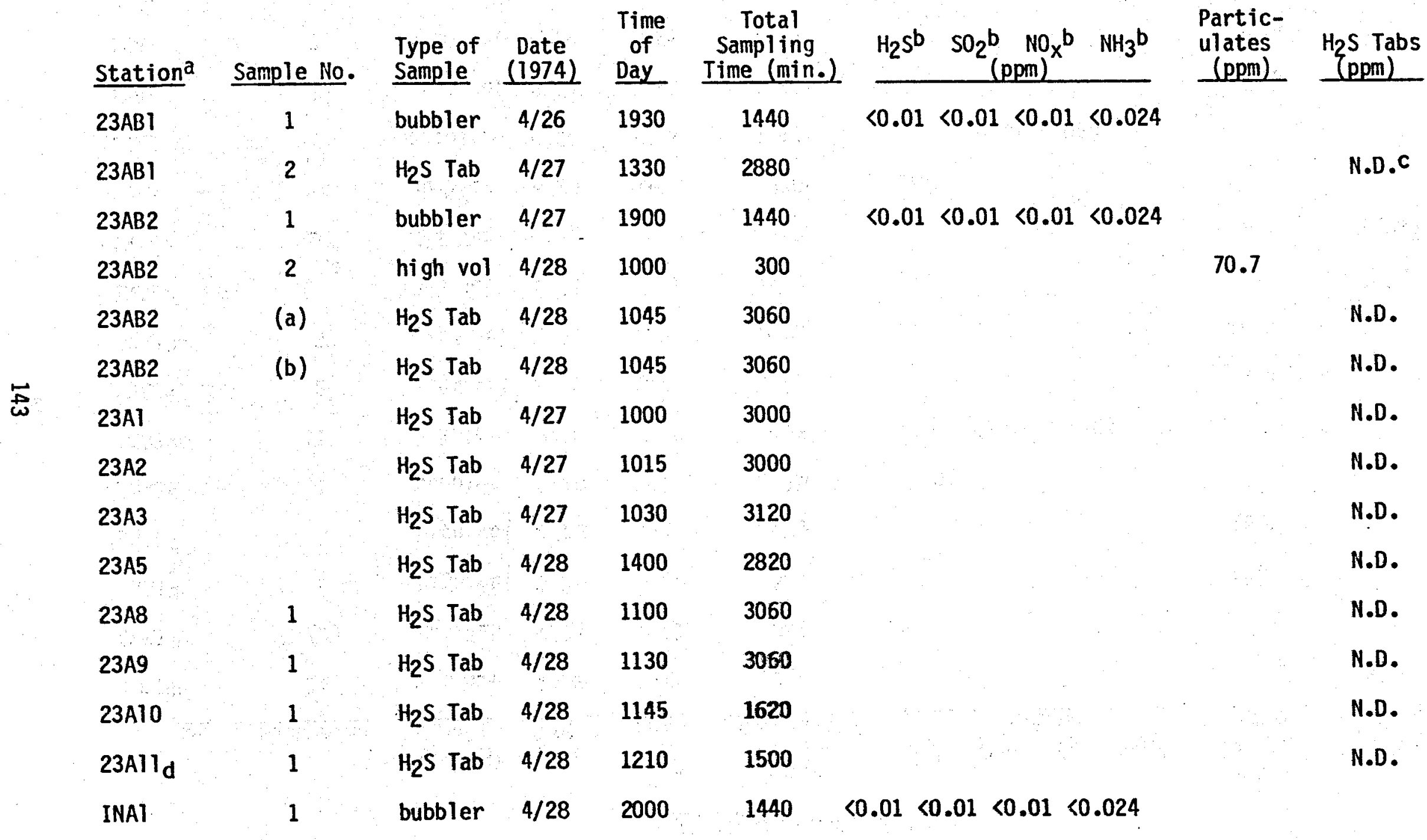


TABLE 3 (Continued)

AMBIENT AIR SAMPLING DATA

\begin{tabular}{|c|c|c|c|c|c|c|c|c|c|}
\hline Station $^{\mathrm{a}}$ & Sample No. & $\begin{array}{l}\text { Type of } \\
\text { Sample }\end{array}$ & $\begin{array}{l}\text { Date } \\
(1974)\end{array}$ & $\begin{array}{c}\text { Time } \\
\text { of } \\
\text { Day } \\
\end{array}$ & $\begin{array}{c}\text { Total } \\
\text { Sampling } \\
\text { Time (min.) } \\
\end{array}$ & $\mathrm{H}_{2} \mathrm{Sb}^{\mathrm{b}}$ & $\underset{(\mathrm{ppm})}{\mathrm{SO}_{2} \mathrm{~b}} \mathrm{NO}^{\mathrm{b}} \quad \mathrm{NH}_{3}{ }^{\mathrm{b}}$ & $\begin{array}{l}\text { Partic- } \\
\text { ulates } \\
\text { (ppm) } \\
\end{array}$ & $\begin{array}{l}\mathrm{H}_{2} \mathrm{~S} \text { Tabs } \\
(\mathrm{ppm})\end{array}$ \\
\hline INA1d & (a) & $\mathrm{H}_{2} \mathrm{~S}$ Tab & $4 / 28$ & 1045 & 300 & & & & N.D. \\
\hline INA1 d & (b) & $\mathrm{H}_{2} \mathrm{~S} \mathrm{Tab}$ & $4 / 28$ & 1045 & 300 & & & & N.D. \\
\hline INAId & 2 & high vol & $8 / 19$ & 1500 & 1480 & & & 43.9 & \\
\hline INA1 $^{d}$ & 3 & high vol & $8 / 20$ & 1717 & 820 & & & 26.2 & \\
\hline INA2e & 1 & bubbler & $8 / 18$ & 1345 & 630 & $<0.01$ & & & \\
\hline INA2e & 1 & bubbler & $8 / 18$ & 1345 & 1445 & $<0.01$ & $<0.01<0.104$ & & \\
\hline INA2 ${ }^{2}$ & 2 & high vol & $8 / 18$ & 1345 & 1445 & & & 15.4 & \\
\hline INA2e & 3 & high vol & $8 / 21$ & 1500 & 1440 & & & 26.5 & \\
\hline INA2e & (a) & $\mathrm{H}_{2} \mathrm{~S}$ Tab & $8 / 21$ & 1500 & 1440 & & & & N.D.f \\
\hline INA2 $^{e}$ & (b) & $\mathrm{H}_{2} \mathrm{~S}$ Tab & $8 / 21$ & 1500 & 1440 & & & & N.D.f \\
\hline INA3 & 1 & bubbler & $8 / 20$ & 0950 & 370 & $<0.01$ & & & \\
\hline INA3 & 1 & bubbler & $8 / 20$ & 1715 & 1440 & & $<0.01 \quad 0.068$ & & \\
\hline INA3 & 2 & high vol & $8 / 18$ & 1615 & 1430 & & & 40.3 & \\
\hline INA3 & 3 & high vol & $8 / 19$ & 1615 & 1440 & & & 38.0 & \\
\hline INA3 & 4 & high vol & $8 / 20$ & 1635 & 1380 & & & 56.7 & \\
\hline INA3 & 5 & high vol & $8 / 21$ & 1535 & 1445 & & & 51.7 & \\
\hline
\end{tabular}


TABLE 3 (Continued)

\section{AMBIENT AIR SAMPLING DATA}

\begin{tabular}{|c|c|c|c|c|c|c|c|c|c|c|}
\hline Stationa & Sample No. & $\begin{array}{l}\text { Type of } \\
\text { Sample }\end{array}$ & $\begin{array}{c}\text { Date } \\
\text { (1974) } \\
\end{array}$ & $\begin{array}{l}\text { Time } \\
\text { of } \\
\text { Day }\end{array}$ & $\begin{array}{c}\text { Total } \\
\text { Sampling } \\
\text { Time (min.) } \\
\end{array}$ & $\mathrm{H}_{2} \mathrm{Sb}^{\mathrm{b}}$ & ${ }_{(\mathrm{ppm})}^{\mathrm{SO}_{2}{ }^{\mathrm{b}} \mathrm{N}^{\mathrm{NO}}}$ & $\mathrm{NH}_{3}{ }^{\mathrm{b}}$ & $\begin{array}{l}\text { Partic- } \\
\text { ulates } \\
(\mathrm{ppm}) \\
\end{array}$ & $\begin{array}{l}\mathrm{H}_{2} \mathrm{~S} \text { Tabs } \\
\text { (ppm) }\end{array}$ \\
\hline INA49 & 1 & bubbler & $8 / 17$ & 1015 & 420 & $<0.01$ & & & & \\
\hline INA49 & 1 & bubbler & $8 / 17$ & 1015 & 1245 & $<0.01$ & $<0.01$ & & & \\
\hline INA49 & 1 & bubbler & $8 / 17$ & 1015 & 1440 & & 0.075 & & & \\
\hline INA49 & 2 & bubbler & $8 / 18$ & 1015 & 315 & & & 0.034 & & \\
\hline INA49 & 3 & high vol & $8 / 17$ & 1037 & 300 & & & & 30.1 & . \\
\hline INA49 & 4 & high vol & $8 / 17$ & 1815 & 750 & & & & 16.5 & \\
\hline INA4h & (a) & $\mathrm{H}_{2} \mathrm{~S}$ Tabs & $8 / 17$ & 1030 & 1 & & & & & 8.0 \\
\hline INA4 ${ }^{i}$ & (b) & $\mathrm{H}_{2} \mathrm{~S}$ Tabs & $8 / 17$ & 1045 & 2 & & & & & 9.5 \\
\hline$I^{\prime N A} 4^{j}$ & (c) & $\mathrm{H}_{2} \mathrm{~S}$ Tabs & $8 / 17$ & 1000 & 150 & & & & & 0.15 \\
\hline INA4k & (d) & $\mathrm{H}_{2} \mathrm{~S}$ Tabs & $8 / 17$ & 1000 & 50 & & & & & N.D. \\
\hline INA4 1 & (e) & $\mathrm{H}_{2} \mathrm{~S}$ Tabs & $8 / 17$ & 1000 & 135 & & & & & N.D. \\
\hline INA4M & (f) & $\mathrm{H}_{2} \mathrm{~S}$ Tabs & $8 / 17$ & 1000 & 1590 & & & & & N.D. \\
\hline INA4n & (g) & $\mathrm{H}_{2} \mathrm{~S}$ Tabs & $8 / 17$ & 1000 & 1590 & & & & & N.D. \\
\hline INA5O & 1 & bubbler & $8 / 21$ & 1210 & 122 & 0.10 & $3<0.01$ & & 38.0 & \\
\hline
\end{tabular}


TABLE 3 (Continued)

\section{AMBIENT AIR SAMPLING DATA}

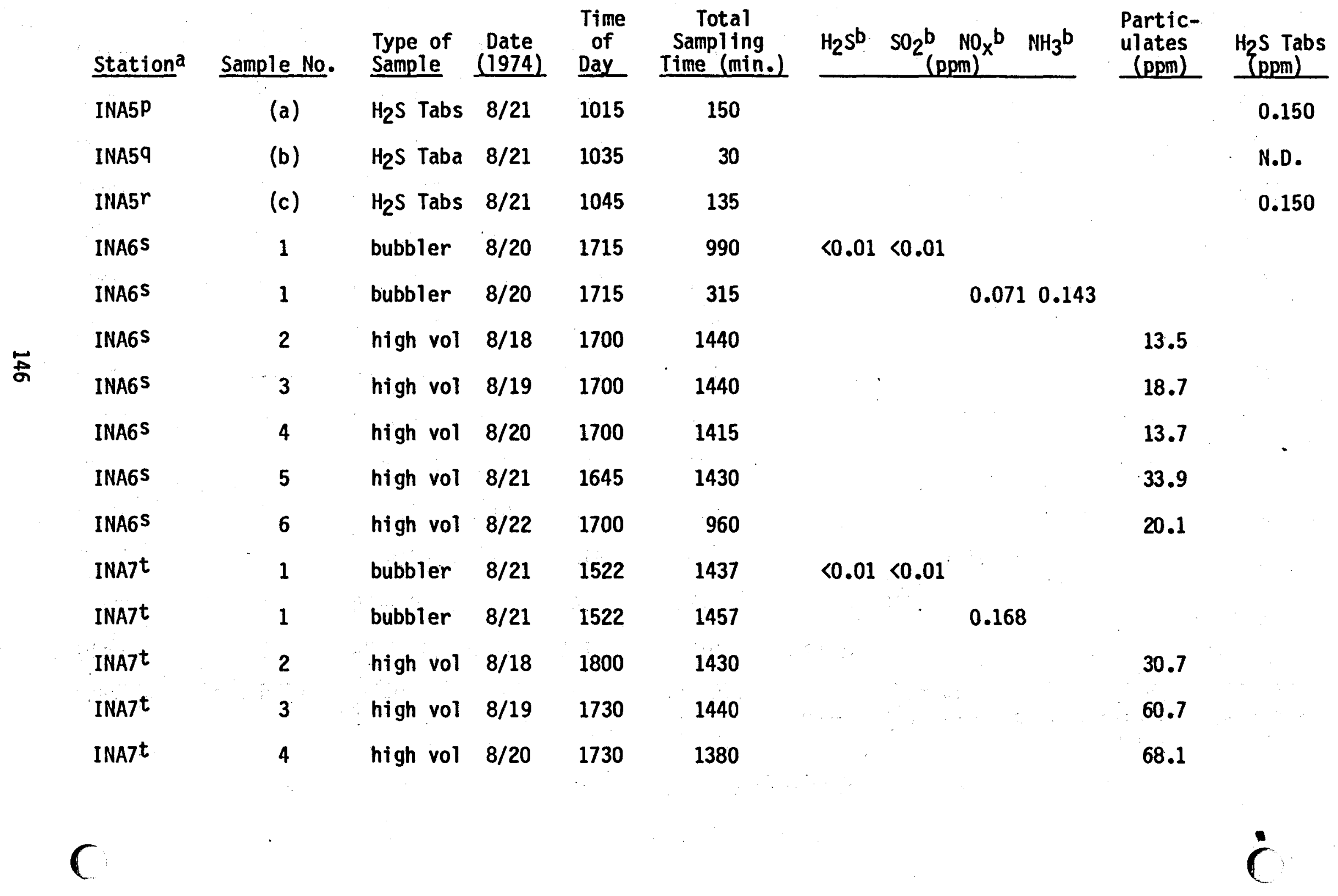


TABLE 3 (Continued)

\section{AMBIENT AIR SAMPLING DATA}

\begin{tabular}{|c|c|c|c|c|c|c|c|c|c|}
\hline Stationa & Sample No. & $\begin{array}{l}\text { Type of } \\
\text { Sample }\end{array}$ & $\begin{array}{c}\text { Date } \\
\text { (1974) } \\
\end{array}$ & $\begin{array}{c}\text { Time } \\
\text { of } \\
\text { Day }\end{array}$ & $\begin{array}{c}\text { Total } \\
\text { Sampling } \\
\text { Time (min.) } \\
\end{array}$ & $\begin{aligned} & \mathrm{H}_{2} \mathrm{~S}^{\mathrm{b}} \mathrm{SO}_{2}{ }_{(\mathrm{ppm})}^{\mathrm{b}} \mathrm{NO}^{\mathrm{b}} \\
&\end{aligned}$ & $\mathrm{NH}_{3} \mathrm{~b}$ & $\begin{array}{l}\text { Partic- } \\
\text { ulates } \\
\text { (ppm) }\end{array}$ & $\begin{array}{c}\mathrm{H}_{2} \mathrm{~S} \text { Tabs } \\
\text { (ppm) }\end{array}$ \\
\hline INA7t & 5 & high vol & $8 / 21$ & 1700 & 1445 & & & 57.7 & \\
\hline INA7t & 6 & high vol & $8 / 22$ & 1515 & 1085 & & & 57.5 & \\
\hline
\end{tabular}

Source: Peterson and Palmer (1977)

asee Fig. 2 for station locations

bMinimum detection limits $(\mathrm{ppm}):<0.01$ for $\mathrm{H}_{2} \mathrm{~S},<0.01$ for $\mathrm{SO}_{2},<0.01$ for $\mathrm{NO}_{\mathrm{x}},<0.24$ for $\mathrm{NH}_{3}$

E CN.D. = not detected

dMeteorological Station No. 1

eMeteorological Station No. 2

fTabs installed in high vol. shelter in air stream

gCasa Diablo. Hot Springs 10 meters east and 2 meters down slope of hot gas vent

hCasa Diablo steam vent

i3-12 inches from Casa Diablo steam vent

j30 feet above Casa Diablo steam vent

$k_{15}$ feet west of Casa Diablo steam vent

$1_{60}$ feet east of Casa Diablo steam vent 


\section{TABLE 3 (Continued)}

\section{AMBIENT AIR SAMPLING DATA}

$m_{120}$ feet east of Casa Diablo steam vent

n200 feet east of Casa Diablo steam vent

OHot Creek

PHot Creek near large hot spring with observation deck

qHot Creek, 80 meters upstream from hot springs and new activity

rHot Creek, 100 meters upstream from hot springs

SMammoth Lakes water treatment plant

$\stackrel{\$}{\infty}$

$t_{\text {Mammoth Lakes fire house roof }}$ 


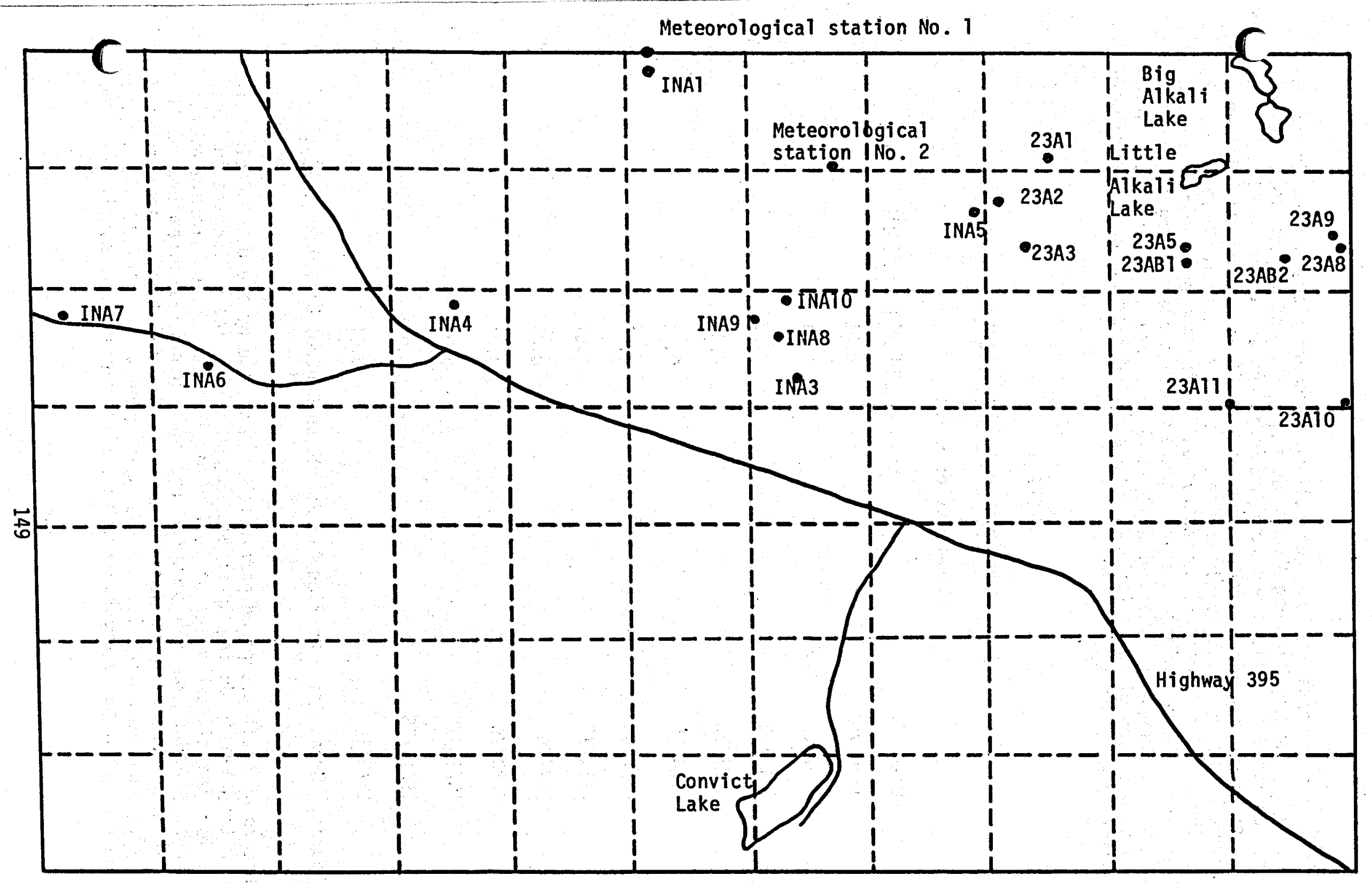

Fig. 2. Locations of ambient air monitoring stations (from Peterson and Palmer 1977). See Table 3 for data. 
Short-term measurements of hydrogen sulfide concentrations were made by the U.S. Geological Survey in Long Valley during April and August 1974. These data are tabulated in Table 3 and sampling locations are given in Fig. 2 . The only places where $\mathrm{H}_{2} \mathrm{~S}$ was detected were within 100 meters of the Hot Spring at Hot Creek and immediately above the vent of a geothermal well at Casa Diablo. The minimum detectable concentration for the hydrogen sulfide samples was $0.01 \mathrm{ppm}$. Union Carbide measured the ambient concentration of hydrogen sulfide at its tungsten mine and mill at Rovana one day per month during 1975. These data are given in Table 4. The sampling location and meteorological conditions were not specified.

TABLE 4

AMBIENT HYDROGEN SULFIDE ANALYSES

(Community of Rovana)

Date

$\mathrm{H}_{2} \mathrm{~S}$ Concentrations (ppm)

$1 / 30 / 75$

0.01

$2 / 3 / 75$

0.01

$3 / 10 / 75$

0.0 ?

$3 / 27 / 75$

0.007

$4 / 24 / 75$

0.01

$5 / 8 / 75$

0.007

$6 / 11 / 75$

0.01

$7 / 7 / 75$

0.01

$9 / 30 / 75$

0.015

$10 / 24 / 75$

0.01

$11 / 11 / 75$

0.005

$12 / 5 / 75$

0.01

Source: Great Basin Unified Air Pollution Control District (1976).

Measurements of total suspended particulates were made by the U.S. Geological Survey in Long Valley during April and August 1974. These data are included in Table 3. The highest value of $70.7 \mu \mathrm{g} / \mathrm{m}^{3}$ is below the California ambient air quality standard of $100 \mathrm{\mu g} / \mathrm{m}^{3}$. The only other measurements in the geothermal area were made at Mammoth Lakes by the California Air Resources Board during June and July 1974. The measurements were 147.2, 154.3, and $178.1 \mathrm{\mu g} / \mathrm{m}^{3}$. Five measurements made in Bishop during this sampling period 
ranged from 52.7 to $198.2 \mu \mathrm{g} / \mathrm{m}^{3}$. Additional measurements by the ARB in Great Basin Valleys outside the geothermal area during 1972-1973 are given in Tables 5 and 6 . All of the total suspended particulate measurements were made with $\mathrm{Hi}$-Vol Samplers.

\section{Data Banking}

The few source, meteorological and air quality data avilable for the Mono-Long Valley KGRA have been taken by a variety of individuals and organizations. Some data have been included in informal reports, but many exist only in tabulations or on charts. In the course of compiling their report, Peterson and Palmer (1977) collected most of these data, and their report represents a convenient source. Some of the data, particularly unpubiished data from the Little Antelope Valley and Hot Creek meteorological towers, is probably only available from T. Palmer.

\section{CONCLUSIONS}

Comparison of available air quaitity data with data required to make assessments of potential impacts of geothermal development on air quality reveals significant gaps in all areas.

\section{A. Sources}

The few measurements of the composition of geothermal gases often do not include data on significant potential pollutants. Data that are available apply to shallow geothermal wells, while any significant development of the resource will depend on production from deep wells where the composition of the geothermal fluid may be much different. There are not even sufficient data to identify which substances are likely to have the most significant environmental impacts. In addition, plans for development have not yet advanced to the stage where the processing of the geothermal fluid in the plant and the relative amount of emission and reinjection can be estimated. For many of the plant cycles that can be considered, knowledge of the disposition of the various components of the geothermal fluid is unavailable, since similar plants have not yet been built or tested. Before air quality assessments can even be started, a significant amount of data is required on the composition of the geothermal fluid input to the plant, and on the processing and emission of various constituents by the plant.

There have been measurements of the composition of some hot springs, but no measurement of the rate of emission to the atmosphere of substances that may affect air quality. There are no data on the natural emission rates of hydrogen sulfide or mercury vapor, and no survey has been made of the characteristics of active fumaroles and hot springs. Therefore, it is not possible to make even a crude estimate of natural emissions.

There have been no studies of dust suspension in this region and how winds, vegetation, surface cover by snow, and surface disturbance (e.g., construction) would affect the suspension of dust.

Cooling towers operated in conjunction with geothermal plants have the potential for releasing significant quantities of water vapor to the atmosphere. 
TABLE 5

SUMMARY OF TOTAL SUSPENDED PARTICULATE LEVELS, JUNE-JULY 1972 (24-HR SAMPLES, $\left.\mathrm{g} / \mathrm{m}^{3}\right)$

\begin{tabular}{|c|c|c|c|c|c|c|c|c|c|c|c|c|c|c|}
\hline Station & $\begin{array}{l}\text { Total } \\
\text { No. of } \\
\text { Samples }\end{array}$ & Max. & $10 \%$ & $\begin{array}{r}\text { Conc } \\
\text { by } \\
20 \% \\
\end{array}$ & $\begin{array}{r}\text { ntrati } \\
\text { tated } \\
30 \% \\
\end{array}$ & $\begin{array}{c}\text { ons Equ } \\
\text { Percent } \\
40 \% \\
\end{array}$ & $\begin{array}{l}11 e d \\
\text { of al1 } \\
50 \% \\
\end{array}$ & $\begin{array}{l}r \text { Exceedec } \\
\text { Samples } \\
60 \% \\
\end{array}$ & $70 \%$ & $80 \%$ & $90 \%$ & Min & $\begin{array}{l}\text { Geo- } \\
\text { metric } \\
\text { Mean } \\
\end{array}$ & $\begin{array}{l}\text { Std. } \\
\text { Dev. }\end{array}$ \\
\hline Bishop & 21 & 141 & 123 & 110 & 101 & 98 & 85 & 82 & 79 & 65 & 57 & 32 & 83.4 & 1.4 \\
\hline Bridgeport & 26 & 108 & 82 & 63 & 59 & 52 & 49 & 41 & 32 & 28 & 17 & 14 & 42.8 & 1.7 \\
\hline Lee Vining & g 19 & 87 & 74 & 73 & 59 & 50 & 48 & 43 & 39 & 31 & 24 & 21 & 45.5 & 1.5 \\
\hline $\begin{array}{l}\text { Lone Pine } \\
\text { Airport }\end{array}$ & 21 & 185 & 113 & 93 & 81 & 51 & 47 & 44 & 43 & 34 & 23 & 11 & 51.2 & 2.0 \\
\hline
\end{tabular}


TABLE 6

SUMMARY OF TOTAL SUSPENDED PARTICULATES (OCTOBER 1972-JUNE 1973)

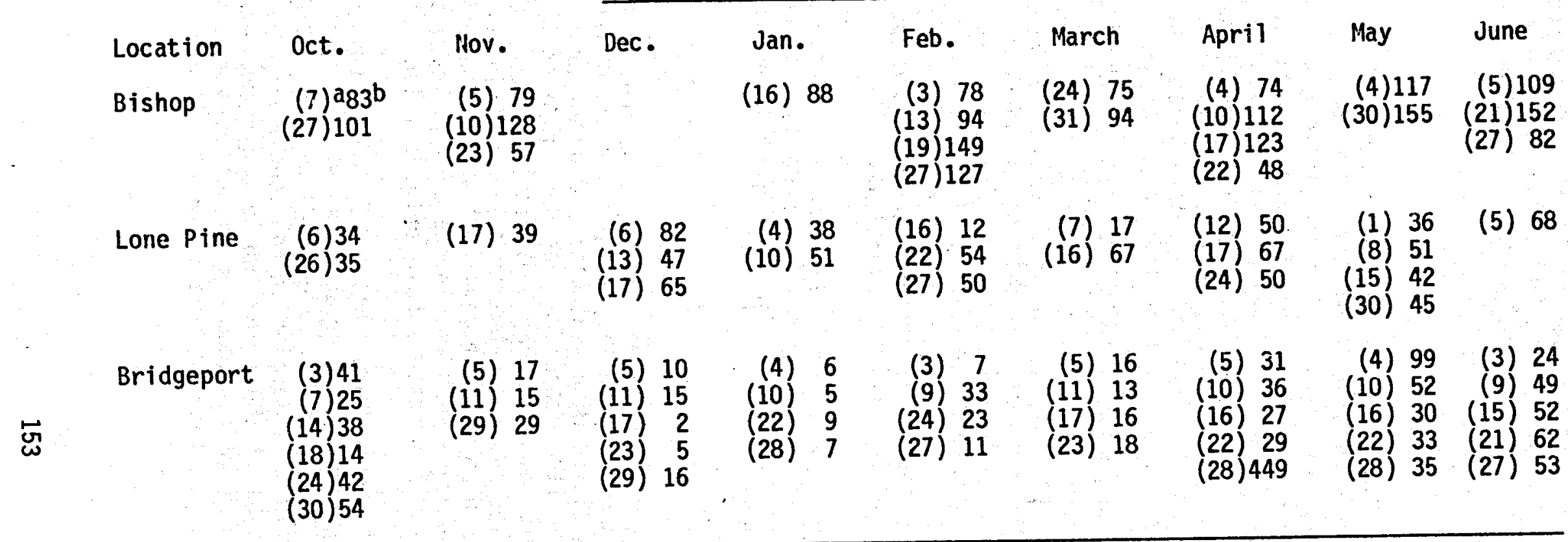

Source: Great Basin Unified Air Pollution Control District (1976)

aDay of month in parentheses.

bparticulate concentration in $\mathrm{g} / \mathrm{m}^{3}$. 
Such releases could have an effect on precipitation, particularly snowfall, and on fog occurrence. Operating characteristics of cooling towers are generally known, but some of the temperatures, humidities and thermal stratifications that can be encountered in Mono Basin and Long Valley are unusual and may require special consideration.

\section{B. Meteorological Data}

The scarcity of meteorological data within Mono-Long Valley KGRA is surprising, particularly for the most important parameter of wind. Useful data consist of 1 year of measurements at $5 \mathrm{~m}$ and $15 \mathrm{~m}$ in Little Antelope Valley and 6 months of data at the same heights above the plateau north of the Hot Creek Fish Hatchery. The location and topography of the area have a dominant influence on the air flow, so that measurements at any given location are subject to local influences and not generally representative of the area. This is particularly true for the data in Little Antelope Valley, which is a nearly enclosed basin with only a small exit to the east. Before any estimates can be made of the impact of geothermal pollutants, an extensive set of meteorological data on winds, turbulence characteristics, and thermal stratifications will be required. There is no current effort to acquire such data. The flow fields that have been hypothesized for this region are based on the limited observations of various authors. Acquiring an understanding of atmospheric transport and diffusion in this area and performing air quality assessments will be extremely difficult because of the complexity of the terrain and its dominance on the flow fields. The dryness of the region acts to enhance the terrain effects by maximizing radiative heating and cooling and permitting formation of very strong temperature inversions.

There are no recorded data within the KGRA on visibility, cloudiness, and fog. Since visibility degradation and increases in the frequency of fog occurrence are potentially important impacts of geothermal development, lack of background data is a serious deficiency.

\section{Air Quality Data}

There are only a few irregular short-term measurements of ambient air concentrations of pollutants within Mono-Long Valley KGRA, and most of these data are for substances normally associated with vehicular and urban sources. The only measurements of hydrogen sulfide concentrations were made on 3 days in April and 5 days in August 1974 by the U.S. Geological Survey. The only hydrogen sulfide detected occurred when the detectors were within $100 \mathrm{~m}$ of a large hot spring and immediately above a geothermal well vent. These data are not sufficient to describe background conditions in the Long Valley geothermal area, but they suggest that natural emissions have only very local impacts.

Measurements of total suspended particulates include $21 \mathrm{Hi-Vol}$ samples at 7 locations within the Long Valley geothermal area on the same .8 days in 1974 that hydrogen sulfide concentrations were measured, and $3 \mathrm{Hi}-\mathrm{Vol}$ samples in Mammoth in June and July 1974. All the samples in the Long Valley geothermal area were below the state standard of $100 \mu \mathrm{g} / \mathrm{m}^{3}$, while the three samples at Mammoth were near $150 \mu \mathrm{g} / \mathrm{m}^{3}$. These few samples do not provide adequate background data on particulates, but they do tend to indicate the effects of human activity. 


\section{RECOMMENDATIONS}

The preceding sections of this report have shown that significant gaps exist between available data and data needed to make air quality assessments. These gaps are especially serious because of several characteristics of the region. The flow fields that disperse pollutants are so dominated by the complex terrain that meteorological data requirements are much greater than for most regions. The high value placed on recreation and the dependence of this value on the currently excellent air quality will certainly lead to a very critical examination of any attempts to predict air quality impacts. The relative remoteness of this region has left it with an unusually small set of meteorological and air quality data. Because of these tremendous data gaps, assessment of air quality impacts that must precede any geothermal development that includes atmospheric emissions will require a major data gathering effort. Attempts may be made to circumvent this effort because of the associated costs and to streamline the environmental assessment. For this region such an occurrence would be a major error and would result in tremendous future conflicts.

In the remainder of this section 11 specific recommendations for measurements and research are listed in priority order. Priority is based more on need for early implementation than on overall importance. Before an adequate analysis of impacts of geothermal development can be completed, data and results for all these recomendations will be required.

1. Baseline data on visibility and fog. The most serious potential air quality impact of geothermal development has already been identified as periodic reduction in visibility. To provide a quantitative measure of pre-development conditions it is very essential to establish a station in Long Valley, and perhaps Mono Basin, where visiblity and fog frequency characteristics are routinely measured. Additional baseline data on fog should include particle size distribution, drop composition, air and water temperatures, and fog layer depth.

2. Baseline data on $\mathrm{H}_{2} \mathrm{~S}, \mathrm{Rn}, \mathrm{Hg}, \mathrm{NH}_{3}, \mathrm{CH}_{4} \cdot$ The second most serious impact of geothermal development is an increase in odor detection of hydrogen sulfide. A comprehensive survey of measurements is needed to provide a current assessment of the effects of natural $\mathrm{H}_{2} \mathrm{~S}$ emissions. In conjunction with this survey, measurements of radon, mercury, ammonia, and methane concentrations should be made.

3. Natural emissions. A survey of atmospheric emissions from fumaroles and hot springs should be made to provide an estimate of current total emissions for comparison with future geothermal development emissions, and to determine the effects of development on natural emissions. Such a survey would inciude a mapping of natural fumaroles and hot springs in the area, measurement of flow rates, concentration measurements of pollutants and pollutant emission rates. Particular emphasis should be on hydrogen sulfide.

4. Dust characteristics. A study is needed of several properties of dust particles and the susceptibility of various local surfaces to suspend dust. These data include measurements of dust loadings and particle size distribution in various wind conditions, chemical composition of dust emitted from geothermal wells, effects of surface disturbance (construction) and surface 
moisture and cover on dust suspension, and optical properties (visibility reducing power) of dust particles.

5. Permissible air quality changes. The unique air quality features of Mono-Long Valley KGRA have been mentioned. It is quite clear that local residents expect air quality to remain excellent and this implies that permissible change may have different criteria than what might otherwise be suggested by current state and federal air quality standards. Now is the time for local planning and decisions on what changes in air quality are locally acceptable.

6. Surface meteorological data. The key element in any air quality assessment is determining the transport of pollutants from a source to a receptor, including the effects of dispersion. Such determinations require data on wind speed, direction and fluctuations. A network of surface stations is required to collect such data over a reasonable period of time. The stations must be located to measure representative flow fields. They should not be unduly affected by local terrain features, but should represent significant influences of local terrain, a most difficult compromise that may depend on site-specific emissions. It has already been mentioned that the Mono-Long Valley KGRA can be divided into two independent regions, a northern region including Mono Basin, and a southern region including Long Valley. Development in Long Valley appears more imminent, and an observing network of stations was suggested in the Air Quality Workshop at Mammoth Lakes Village on August 10-11, 1978. The network included stations at Long Valley Dam, along the Owens River, near Glass Mountain, at Mammoth Airport, at Mamnoth Ranger Station, at Tom's Place, and in Mammoth Pass. A network of 4 stations in Mono Basin was suggested, with stations on the ridge near June Lake, at Lee Vining, east of Mono Lake and north of Mono Lake. It was recommended that these surface stations have 10-meter towers to measure wind speed, direction and fluctuations, and also measure temperature, humidity and solar radiation. Measurement of inversion heights using acoustical sounders was suggested at Casa Diablo and Mono Lake.

7. Emission rates and characteristics of geothermal facilities. Knowledge of emission rates and characteristics are required to make air quality assessments. If deep geothermal wells are drilled it will. be necessary to measure the chemical composition of the fluid with particular emphasis on potential pollutants. If power plants are designed, specific consideration must be given to determining the disposition of the geothermal fluid within the plant and estimating the rate and characteristics of emissions.

8. Upper level meteorological data. Most geothermal emissions occur tens of meters above the surface, but within the boundary layer. Therefore, data on winds at levels up to a few $\mathrm{km}$ above the surface will be required to specify the transport of pollutants. In addition the vertical temperature structure which dominates vertical transport must be measured. Workshop participants suggested routine pibal soundings taken at Mammoth Airport and at Mono Lake, supplemented with aircraft soundings.

9. Site specific transport. As development plans proceed and source characteristics are defined, site specific transport studies will be required to assess effects of local transport on air quality. Data requirements at this 
stage include a denser surface meteorological network, and release and measurement of the dispersal of a tracer simulating geothermal emissions.

10. Transport model. Assessment of air quality effects depends upon a model of pollutant transport. In the complex terrain and meteorology of Mono-Long Valley, simple models will not be adequate. Fortunately, basic research in turbulent transport and air pollution is beginning to attack the problem of complex terrain modeling. Such models, when available, should be applied and validated for Mono-Long Valley KGRA.

11. Cooling tower effects. The Mono-Long Valley region presents a climatically unusual environment for cooling towers. Studies will be required to evaluate the effectiveness of cooling towers in these conditions, and the effects of cooling tower emissions of water vapor on fog and precipitation in the local area. Dissipation and visibility of cooling tower plumes may also prove to be a major concern from an aesthetic viewpoint in this region; therefore, characteristics of these plumes need to be studied.

\section{ACKNOWLEDGMENTS}

The following people participated in the discussions of the air quality section at the workshop in Mamnoth Lakes, August 10-11, 1978: Robert Alexander (Mammoth Lakes), John Evans (Battelle Northwest Laboratories), Paul Gudiksen (Lawrence Livermore Laboratory), John S. Kirby-Smith (UCLA), Charles Molenkamp (Lawrence Livermore Laboratory), Neil Moyer (California Air Resources Board), Thomas $Y$. Palmer (SWETL, Inc.), Kendall Peterson (Lawrence Livermore Laboratory), and Paul Phelps (Lawrence Livermore Laboratory).

Charles Fryxell (Great Basin Unified Air Pollution Control District) and Tom Palmer critically reviewed the draft version of this chapter.

Carl Strojan supplied the photograph in Figure 2. 


\section{REFERENCES CITED}

California Department of Water Resources. 1967. Investigation of geothermal waters in the Long Valley area, Mono County. $141 \mathrm{p} .+7 \mathrm{pl}$.

Great Basin Unified Air Pollution Control District. 1976. Implementation plan for achieving and maintaining ambient air quality standards in the Great Basin Valleys Air Basin, Revision No. 1. Great Basin Unified Air Pollution Control District, Bishop, Calif.

James A. Roberts Associates, Inc. 1973. Preliminary natural resource baseline and environmental sensitivity analysis for Mammoth. In Monoplan phase 2: Environmental background reports. South Pasadena, Calif., Monoplan Associates, 111 p.

Lewis, R. E. 1974. Data on wells, springs, and thermal springs in Long Valley, Mono County, California. U.S. Geol. Survey, open-file report, $52 \mathrm{p}$.

Mariner, R. H. and L. M. Willey. 1976. Geochemistry of thermal waters in Long Valley, Mono County, California. J. Geophys. Res. 81:792-800.

McNitt, J. R. 1963. Exploration and development of geothermal power in California. California Division of Mines and Geology, Special Report 75, 44 p.

Muffler, L. J. P. (ed.). 1979. Assessment of geothermal resources of the United States--1978. U.S. Geol. Survey Circular 790, 163 p.

Peterson, K. R. and T. Y. Palmer. 1977. Climatology and air quality of Long Valley geothermal resource area. Lawrence Livermore Laboratory Report UCID-17459, Rev. 1, 29 p. + 5 App.

Sasaki, Walker, Roberts, Inc. 1975. Draft environmental statement for Monoplan for Mammoth. Sausalito, Calif., SWR, 245 p. + App.

Winkler, D. W. (ed.). 1977. An ecological study of Mono Lake, California. Institute of Ecology Publication No. 12, University of California, Davis, $184 \mathrm{p}$. 


\section{Chapter 6}

\section{ECOSYSTEMS OVERVIEW}

\section{Carl L. Strojan \\ Laboratory of Nuclear Medicine and Radiation Biology \\ University of California, Los Angeles}


TABLE OF CONTENTS

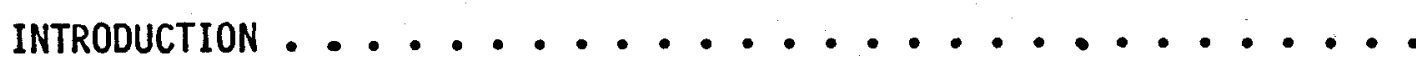

General Environmental Effects of Geothermal Development .....

EXISTING ECOLOGICAL DATA BASE $\ldots \ldots \ldots \ldots$

Data Sources $\ldots \ldots \ldots 161$

General Ecology of the KGRA ......................... 162

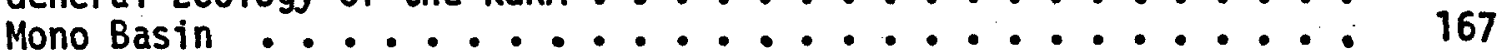

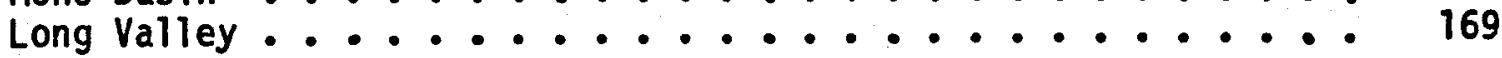

KEY ISSUES AND DATA GAPS ....................... 171

Hot Creek Fish Hatchery ................. 172

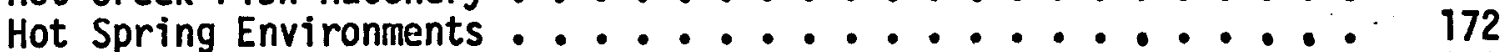

Habitat Loss to Vegetation and Wildlife .............. 172

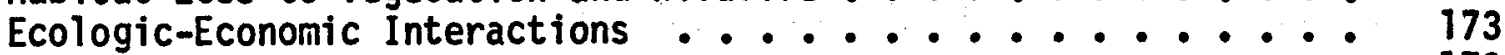

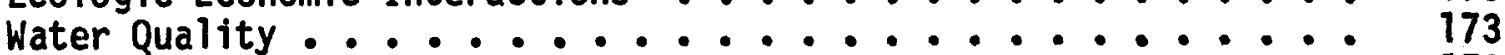

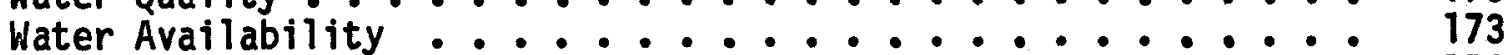

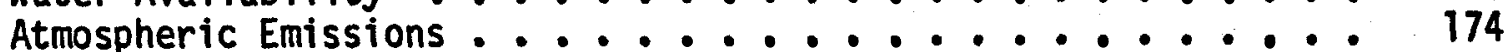

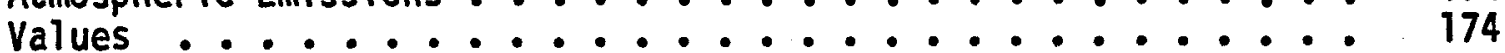

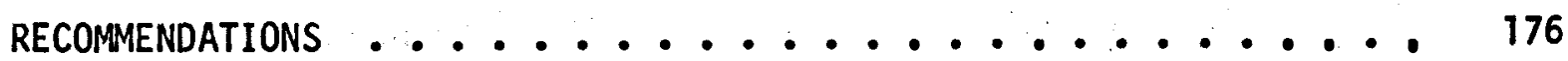

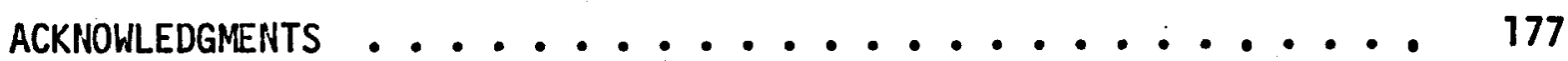

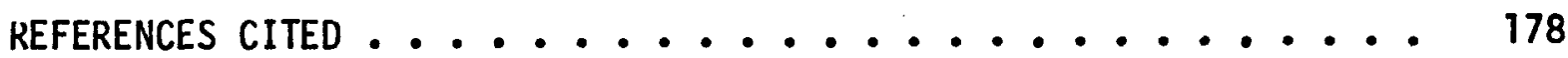

APPENDIX A: ECOLOGICAL DATA SOURCES ............. 182

\section{LIST OF TABLES}

1. Major Vegetation Types ................ 162

2. Rare, Endangered, and Unusual Plant Species ........ 165

3. Rare, Endangered, and Unusual Animal Species ........ 166

4. Average Chemical Concentrations in Convict Lake,

Mono Lake, and Sea Water............... 168

5. Comparative Brown Trout Biomass in Various Streams ...... 170

6. Major Ecological Issues ................. 174

7. Recomendations ...................... 175 


\section{INTRODUCTION}

The following chapter will concern biotic components of natural ecosystems in Mono-Long Valley KGRA. It will consider general environmental effects of geothermal energy development, existing ecological data for the KGRA, specific ecological issues involved in geothermal development in Mono-Long Valley, and recommendations to help resolve key issues so that development will not be detrimental to existing ecosystems.

General Environmental Effects of Geothermal Development

Several attempts have been made to identify and assess important environmental effects related to geothermal energy development (Goldsmith 1971, Bowen 1973, U.S. Department of the Interior 1973, Anderson and Bowen 1974, Kruger 1976, U.S. Environmental Protection Agency 1977, and U.S. Department of Energy 1978). Many of these effects are important to natural ecosystem functioning. For example, land use for well pads, pipelines, power plants, roads, etc. can alter or destroy critical wildlife habitat and migration routes. Removal of geothermal fluids may disrupt surface hot springs and biological comminities adapted to that environment. Increased soil erosion can cause siltation of streams and lakes. Atmospheric emissions containing boron and other potentially toxic elements can damage hative vegetation. Noise during construction and operation of facilities may disturb wildife. Aquatic organisms and habitats may be affected by accidental releases of hot geothermal fluids containing potentially toxic chemical elements.

Three points should be emphasized with respect to potential environmental effects and our discussion of Mono-Long Valley. First, environmental effects from geothermal development are generally site-specific and differ with the nature of the geothermal reservoir (steam or hot water), chemical make-up of the geothermal fluids, and the design, size and location of geothermal facilities. In any consideration of Mono-Long Valley KGRA, it is important to remember that the KGRA is large $(-460,256$ acres $)$, the extent of the geothermal resource is not well known, and that development has been suggested for space heating and/or generation of electricity. Second, environmental effects which do occur will most likely take place in the vicinity of the geothermal reservoir. There is limited flexibility in the design and placement of geothermal facilities. They must be situated relatively near the underground reservoir because the steam or hot water cannot be transported any great distance. Since geothermal reservoirs in Mono-Long Valley KGRA are located near areas which are very scenic or otherwise environmentaliy sensitive, concern about environmental degradation is warranted. Finally, not all environmental effects need be detrimental-although most concern is understandably directed toward those which are.

\section{EXISTING ECOLOGICAL DATA BASE}

\section{Data Sources}

One of the major problems in identifying and assessing the quality of existing ecological information is that much of it is contained in unpublished reports and files of various agencies and individuals. Much of the information which does exist consists mainly of habitat descriptions and population inventories. There are few site specific data on ecosystem processes such as production, 
energy flow, and mineral cycling. Identification and assessment of ecological data sources for the KGRA are given in Appendix A. A summary of the information in these sources is given in the following paragraphs.

General Ecology of the KGRA

A diversity of ecosystems exists in Mono-Long Valley KGRA, owing to its size ( $(460,256$ acres) and diversity in surface relief and climate. "The Sierra Nevada rise abruptly along the western border of the KGRA. Their presence dominates the landscape and determines in large part the climatology and life forms which can exist. Elevation in the KGRA ranges from about 6400 $\mathrm{ft}$ above sea level near Mono Lake to slightly over 11,000 ft on Mammoth Mountain. Annual precipitation ranges from about 7 inches in eastern Mono Basin (Winkler 1977, p. 17) to about 56.5 in at Mamoth Mountain Pass (California Department of Water Resources 1967). Flora and fauna at the lower elevations, representative of the Great Basin Desert, give way to montane forests at higher elevations of the Sierra Nevada. Five life zones (Upper Sonoran, Transition, Canadian, Hudsonian, and Alpine-Arctic) can be found on the eastern slope of the Sierra Nevada--all within six miles of the crest (Smith 1976). Few places in the United States have such a range of natural ecosystems within such close proximity of each other.

Most of the region's ecosystems are in a relatively natural state because of low population density and lack of significant industrial or commercial development. A major factor responsible for this situation is that about $95 \%$ of the land in the KGRA is owned by governmental agencies (see Chapter 8). Existing land uses are mainly for watershed, recreation, grazing, and timber production.

Table 1 summarizes major vegetation types found in the KGRA. Their distribution is determined mainly by temperature and moisture (elevation), soils, and microrelief. Lists of plant species found in various parts of the KGRA are given by James A. Roberts Associates, Inc. (1973), the U.S. Department of the Interior (1973), Smith (1976), and Winkler (1977). Data are also available from the Bureau of Land Management and the U.S. Forest Service (Bishop offices).

TABLE 1

MAJOR VEGETATION TYPES

Descriptive Name

Sagebrush
Comments

Dominant over the eastern part of the KGRA and the area around Mono Lake; habitat type most likely to experience geothermal development; dominant shrubs are sagebrush (Artemisia tridentata), bitterbrush (Purshia tridentata) and rabbitbrush (Chrysothamnus spp.); forbs and grasses are also important components. 
Jeffrey Pine

Grassland

Riparian

Pinyon-Juniper

Mountain Brush

Lodgepole pineRed fir

Subalpine forest

Unique habitats
The KGRA contains the largest continuous stand of Jeffrey pine anywhere $\left(-200 \mathrm{mi}^{2}\right.$ from Mammoth Lakes to Mono (raters); understory species consist of shrubs, forbs and grasses, including sagebrush, bitterbrush, rabbltbrush, manzanita (Arctostaphylos patula), and western needlegrass (Stipa occidentalis).

Includes natural and irrigated associations, mainly in Long Valley and Little Antelope Valley. Species include salt grass (Distichlis stricta), meadow foxtail (Alopecurus pratensis), cheatgrass (Bromus tectorum), and Nevada bluegrass (Poa nevadensis).

Found along streams in the KGRA; includes numerous terrestrial and aquatic species such as willow (Salix spp.), black cottonwood (Populus trichocarpa), quaking aspen (Populus tremuloides) wiregrass (Juncus balticus), and spike carex (Carex eleocharis).

Typical species in this association include pinyon (Pinyon monophylla), juniper (Juntperus osteosperma), sagebrush, rabbitbrush, and severat buckwheats (Eriogonum spp.).

- Curlleaf mountain mahogony (Cercocarpus ledifolius) is the dominant species; others include manzanita, snowbrush (Ceanothus velutinus), bush chinquapin (Castanopsis sempervirens), and species from sagebrush habitat.

Occurs at high altitudes $(\sim 8000-9000 \mathrm{ft})$ in areas of the KGRA unlikely to undergo geothermal development. Dominant species are lodgepole pine (Pinus contorta), red fir (Abies magnifica) and white fir (Abies concolor).

occurs at high altitudes $(-9000-10,000 \mathrm{ft})$ in areas of the KGRA unlikely to undergo geothermal development. Dominant species include whitebark pine (Pinus albicaulis), mountain hemlock (Isuga mertensiana), and lodgepole pine.

Includes areas such as hot springs, the alkali lake beds east of Crowley Lake, and pumice flats (e.g. Big Sand Flat, Little Sand Flat, and Smokey Bear flat). These areas are of special interest because rare, endangered, or otherwise unique species inhabit them.

Source: James A. Roberts Associates, Inc. (1973), Smith (1976), U.S. Forest Service data. 
Plant species which are rare, endangered, or otherwise unique are a special component of the native flora. A rare species is one which is restricted in both numbers and distribution, while an endangered species is one threatened with extinction throughout all or a significant portion of its range. Species known to occur in the KGRA are included in Table 2. Astragalus johannishowellii and $A$. monoensis are listed as endangered by the federal government (U.S. Fish and Wildlife Service 1976). Many parts of the KGRA have not been studied, and a thorough inventory would undoubtedly reveal both additional species and locations. The California Native Plant Society has eighteen rare and endangered plant species for all of Mono County on its main list and an additional fifteen species with lower priority or incomplete data (Powell 1974).

A variety of animals exists in the KGRA. Each of the vegetation types in Table 1 has an associated faunal component, although there may be much overlap. According to the U.S. Forest Service (1978, p. 11), more than 75 mamnal, 150 bird, and 15 reptile and amphibian species occur in their MamothMono Planning Unit, an area which includes all Forest Service lands in the KGRA. The U.S. Department of the Interior (1973) 1isted 110 bird, 49 mammal, and 11 reptile and amphibian species as inhabiting the Mammoth-Crowley Lake and Mono Lake portions of the KGRA. About a dozen species of fish also occur in the lakes and streams of the KGRA. Most of these species of fish have been planted for sport fishing and are not native to the area. Lists of animal species in various parts of the KGRA are given by Armstrong (1972), the U.S. Department of the Interior (1973), Smith (1976), and Winkler (1977). Data are also available from the Bureau of Land Management, California Departinent of Fish and Game, and the U.S. Forest Service (Bishop offices).

Animal species in the KGRA which are rare, endangered, or of special interest are shown in Table 3. Both the state and federal government list the bald eagle and peregrine falcon as endangered (California Department of Fish and Game 1978, U.S. Fish and Wildlife Service 1979). California also includes the Owens Tui chub as endangered and the wolverine and bighorn sheep as rare (California Department of Fish and Game 1978). Additional information on the biology and distribution of the Owens Tui chub is given by Miller (1973).

The most important wildlife species in terms of geothermal development are probably sage grouse (Centrocercus urophasianus) and mule deer (Odocoileus hemionus hemionus). Significant populations occur in areas of the KGRA most likely to undergo development. These species will be discussed in more detail later: Rainbow, golden, brown, cutthroat, and eastern brook trout are important species which also have commercial value because of the large number of anglers who come to the area. Existing data on invertebrates are very sparse except for a survey of Convict Lake benthic organisms (Reimers et al. 1955), a survey of aquatic and shore invertebrates of Mono Lake Basin (Winkler 1977), and some unpublished data from Hot Creek collected by the California Department of Fish and Game.

Two areas of the KGRA merit more detailed consideration because of their environmental sensitivity and/or likelihood of geothermal development. These are Mono Basin and Long Valley. 
TABLE 2

RARE, ENDANGERED, AND UNUSUAL PLANT SPECIES

Species

Astragalus johannis-howellii John's locoweed

Astragalus monoensis Mono locoweed

Eriogonum ampull laceum Mono eriogonum

Eriogonum kearneyi var. kearneyi

Kearney's eriogonum

Lupinus duranii Tupine

Lupinus montigenus lupine

Pedicularis crenulata. margined-leaf lousewort

Penstemon papillatus Inyo penstemon

Puccinellia lemmonii alkali grass

Spartina gracilis alkali cordgrass

Thelypodium brachycarpum short-podded thelypodium

Triglochin maritima var. elata arrow-grass
Comments

Rare and endangered; appears restricted to swales near present or former hot springs in the Long Valley area.

Rare and endangered; only known locations are three pumice flats in the KGRA; Big Sand Flat, and Smokey Bear Flat.

Occurs along the shores of Mono Lake; endemic to California and somewhat rare.

Occurs on the northeast shore of Mono Lake; alkali tolerant; rare in California.

of limited distribution, but not truly rare; occurs on pumice flats.

0ccurs on pumice soils in forested areas; has a restricted habitat, but is not rare.

CNPS files list one location near Convict Creek and U.S. highway 395 based on pre-1945 data.

CNPS files list one location near Hilton Creek and U.S. highway 395.

Known sites are the eastern shore of Mono Lake and near Little Alkali Lake.

Occurs in Long Valley; may be added to the federal endangered list because of habitat destruction.

CNPS files list one location near Benton Crossing.

Normal habitat is coastal marsh; hot spring environments in Long Valley enable it to survive cold Sierra winter.

Source: Mary DeDecker, personal communication; California Native Plant Sociey (CNPS) files; Powell (1974) 
TABLE 3

RARE, ENDANGERED, AND UNUSUAL ANIMAL SPECIES

Species

Aplodontia rufa mountain beaver

$\frac{\text { Coturnicops noveboracensis }}{\text { yellow rai }}$

Euderma maculata spotted bat

Falco mexicanus prairie falcon

Falco peregrinus peregrine falcon

Gila bicolor snyderi Owens Tui chub

Gulo Iuscus wolverine

Hal iaeetus leucocephalus leucocephalus southern bald eagle

Ovis canadensis californiana California bighorn sheep

\section{Comments}

Unusual rodent; typical burrows have been seen in the Mammoth Lakes area.

Long Valley was one of the few known breeding sites in California; current status is uncertain.

Formerly classified as rare; may occur in pinyon-juniper and Jeffrey pine forest.

Formerly classified as threatened; present in significant numbers, particularly in the Long Valley area.

Endangered; no known nesting pairs in the KGRA, but several sightings have been made.

Endangered; only known pure population is located in the eight miles of Owens River immediately below Long Valley Dam.

Rare; may occur in small numbers at high altitudes $(>8000 \mathrm{ft}$ ).

Endangered; wintering grounds are at Crowley Lake and June Lake Loop area. No known nesting sites occur in the KGRA.

Rare; may occur in isolated parts of the KGRA unlikely to be developed (e.g. Convict Lake area).

Source: Morris Anderson (personal communication) James A. Roberts Associates Inc. (1973), U.S. Forest Service data. 
Mono Basin

Mono Basin lies at the northern edge of the KGRA, nearly 25 miles from Long Valley to the south. Terrestrial vegetation of the Basin is dominated by sagebrush associations. The dominant feature of the area is Mono Lake, a large inland sea $(\sim 40,000$ acres) with no outlet. Although various aspects of the lake are mentioned in early writings, including those of Mark Twain (1872), ecological research in this region began only recently. Mason (1967) conducted the first systematic investigation on the limnology of the lake. More recently, Winkler (1977) reported the results of a student-originated project sponsored by the National Science Foundation. Research is continuing by members of the study group and others on the lake's ecology and the effect of water diversions by the Los Angeles Department of Water and Power (Mono Lake Comittee 1978a). The studies reported by Mason (1967) and Winkler (1977) are particularly valuable in that they consider both the structure and function of various ecosystem components.

The unusual water chemistry of Mono Lake (Table 4) has important ecological implications. The highly saline and alkaline waters of Mono Lake preclude fish life but not other forms. The existing trophic structure is characterized by low diversity and high productivity. Fewer than six phytoplankton species comprise most of the primary producers (Mason 1967, Winkler 1977). Saline lakes are among the most biologically productive of all lakes (Whittaker 1975, p. 325), and Mono Lake is no exception. Mason (1967) reported primary production to be over $1 \mathrm{~kg} \mathrm{C} \cdot \mathrm{m}^{-2} \cdot \mathrm{yr}^{-1}$.

Higher trophic levels in the lake consist of a small brine shrimp (Artemia salina) which feeds on phytoplankton, and a brine fly (Ephydra hians) which feeds on detritus at the lake's edge. The Artemia salina in Mono Lake are apparently physiologically distinct from populations in both the Great Salt Lake and San Francisco Bay (Bowen 1964). Descriptions of the biology of the brine fly are given by Aldrich (1912). Populations of A. salina typically reach $1000 / \mathrm{m}^{3}\left(28 / \mathrm{ft}^{3}\right)$ and $E$. hians about $5400 / \mathrm{m}^{2}$ (500/ft $\mathrm{ft}^{2}$ (Wink $\left.1 \mathrm{er} 1977\right)$. These two species are the major source of food for over a million birds which annually utilize the lake environs for nesting and migratory stops. About 95\% of the state's breeding population of California Gulls nests at Mono Lake (Mono Lake Committee 1978b). Fall migratory populations of about 750,000 Eared Grebes and 90,000 Wilson's Phalaropes have been estimated at the lake (Mono Lake Cormittee 1978b). Although numerous other bird species have also been recorded in the area (U.S. Department of the Interior 1973, Winkler 1977. Heilbrun et a1. 1978, pp. 868, 870), it is primarily as a nesting site and migratory stop that the lake is important for birds. A list of bird species of Mono Lake which may be of historical interest is given by Fisher (1902).

The unusual lake chemistry is responsible not only for high biological productivity, but also for the formation of the unique tufa towers visible at several places along the lake's shore. These towers are formed underwater by the precipitation of calcium carbonate $\left(\mathrm{CaCO}_{3}\right)$ where calcium-rich underwater springs mix with carbonate-rich lake water. Algae in the lake may enhance tufa formation by altering the bicarbonate-carbonate equilibrium (Scholl and Taft 1964). 
TABLE 4

AVERAGE CHEMICAL CONCENTRATIONS IN CONVICT LAKE, MONO LAKE, AND SEA WATER

\begin{tabular}{|c|c|c|c|c|}
\hline \multicolumn{2}{|c|}{ Constituent } & Convict Lake $^{\mathrm{a}}$ & Mono Lakeb & Sea Water ${ }^{c}$ \\
\hline \multicolumn{2}{|l|}{$\mathrm{Na}$} & $0.001 \mathrm{~g} / 1$ & $29.5 \mathrm{~g} / 1$ & $10.5 \mathrm{~g} / 1$ \\
\hline \multicolumn{2}{|l|}{$\mathrm{CO}_{3}$} & 0.06 & 18.9 & - \\
\hline \multicolumn{2}{|l|}{$\mathrm{Cl}$} & $<0.01$ & 17.6 & 19.0 \\
\hline \multicolumn{2}{|c|}{$\mathrm{HCO}_{3}$} & 0.06 & 11.2 & 0.1 \\
\hline \multicolumn{2}{|l|}{$\mathrm{SO}_{4}$} & 0.009 & 10.3 & 2.5 \\
\hline \multicolumn{2}{|l|}{$k$} & 0.002 & 1.5 & 0.4 \\
\hline \multicolumn{2}{|c|}{ Dissolved Solids } & 0.08 & -90 & -35 \\
\hline \multicolumn{2}{|l|}{ B } & $0.01 \mathrm{mg} / 1$ & $331 \mathrm{mg} / 1$ & $4.6 \mathrm{mg} / 1$ \\
\hline \multicolumn{2}{|l|}{$\mathbf{F}$} & $<0.1$ & 48 & 1.3 \\
\hline \multicolumn{2}{|l|}{ As } & no data & 16 & -0.003 \\
\hline \multicolumn{2}{|l|}{$\mathrm{pH}$} & 7.9 & 9.7 & -8.1 \\
\hline Source: & \multicolumn{4}{|c|}{$\begin{array}{l}\text { bwinkler (1977, p. } 41 \text { ), based on analyses in } 1974 \text { by the Los } \\
\text { Angeles Department of Water and Power }\end{array}$} \\
\hline
\end{tabular}

Although tufa formation occurs underwater, structures are now present along the lake's shore, owing to the receding levels of water in the lake from natural and man-made causes. The present-day lake is a remnant of the much larger Pleistocene Lake Russell, with numerous ancient shorelines evident. In recent times water diversions by the City of Los Angeles have assumed great importance in the decline of the lake level. Four major streams feeding Mono Lake (Parker, Rush, Lee Vining and Walker Creeks) are diverted into Grant Lake and then through tunnels under Mono Craters to the Los Angeles-Owens River Aqueduct. Diversions began in 1940 and were increased in 1970. About 100,000 acre-feet of water per year are now diverted. At this rate, the lake is predicted to continue receding until about the middle of the next century when it will stabilize at about one-half of its present surface area (Los Angeles Department of Water and Power, n.d., Winkler 1977). As the lake recedes it becomes increasingly saline. At some point phytoplankton and brine 
shrimp populations may be threatened by the increased salinity. If this happens the food base, as well as the bird populations which depend on it, will shift or collapse.

Long Valley

Long Valley is the area of the KGRA most likely to undergo geothermal development in the near future. Exploratory drilling has occurred in the past, and there is a continuing interest in its geothermal resources for space heating and electricity generation (see Chapter 2). The U.S. Forest Service (1978) proposed several land management alternatives which include possibilities for geothermal leasing of Forest Service lands in the KGRA. The alternative finally adopted by the Forest Service includes about 26,000 acres for geothermal leasing in Long Valley.

Long Valley is located at the gateway to the recreation complex centered around Mammoth Lakes. Terrestrial and aquatic habitats are diverse and sometimes unique. In addition to being the largest reservoir in the City of Los Angeles aqueduct system, Crowley Lake is one of the most popular fishing areas in California. Around 10,000 people are attracted to its waters on opening day (Smith and Williams 1973)--more than at any other place in the state. The Crowley Lake area is also a wintering ground for southern bald eagles.

Hot Creek is a unique ecological area containing geothermal springs and fumaroles. Hot Creek Fish Hatchery is one of three rainbow trout brood stock hatcheries in California--the other two being Mount Whitney and Mount Shasta. It is operated by the California Department of Fish and Game on land leased from the Los Angeles Department of Water and Power. The fish hatchery utilizes springs having a natural combination of meteoric and geothermal waters. These springs supply about $9000 \mathrm{gal} / \mathrm{min},(570 \mathrm{l} / \mathrm{s})$ of water at a composite temperature of about $57.9^{\circ} \mathrm{F}$--which is near optimum for raising trout (Sorey 1976). Data indicate that about 1 to $3 \%$ of the water in the hatchery springs is contributed by the hot-water system at depth, the remainder being contributed by cold surface springs (Sorey 1976). Both temperature and chemistry of these springs are monitored by the California Department of Fish and Game (See Appendix A).

In addition to increasing the hatchery's productivity and permitting operation on a year-round basis, the elevated water temperatures have allowed the development of a unique strain of fall-spawning rainbow trout. Annual hatchery production includes about 800,000 catchable rainbow trout $(\sim 1 / 3 \mathrm{lb}$ each), about 500,000 fingerling trout, and about 20 million eggs for shipment throughout the western United States (Robert Iselin, personal communication).

Hot Creek itself has high self-sustaining populations of trout (Table 5). It is ranked as one of the top fly fishing streams in the United States (U.S. Department of the Interior 1973, p. v-216), and it is currently designated as a wild trout stream by the California Department of Fish and Game.

While much of the eastern sierra lies under a blanket of snow for the entire winter, the ground surface at areas such as Hot Creek and Casa Diablo remains free of snow because of near-surface geothermal activity. These "thermal islands" serve as feeding and resting grounds for wildlife and result in some 
unusual plant distributions. For example, a variety of arrow-grass (Triglochin maritima var. elata) is able to survive beyond its normal range in such sites (Mary DeDecker, personal communication). At least one endangered plant species (Astragalus johannis-howellii), appears restricted to thermallyaltered soils in the lower Hot Creek area.

A popular year-round bathing area, administered by the U.S. Forest Service, is also located along a section of Hot Creek. About 170,500 people visited this site in 1975 (U.S. Forest Service data).

TABLE 5

COMPARATIVE BROWN TROUT BIOMASS IN VARIOUS STREAMS

Stream

Hot Creek

Little Deschutes River, Oregonb
a) Gulick's
b) $01 d$ Mill
c) Cow Camp
d) Cresent
199
181
83
54

Biomass (1b/acre)

555

Pennsylvania streams $c$
a) Spruce Creek
b) Kettle Creek
c) Spring Creek
d) Young Woman's Creek
e) Shaver Creek
137

i. Source: U.S. Forest Service. Original sources are:

aCalifornia Department of Fish and Game (1975)

boregon Wildlife Commission (1972)

CMcFadden and Cooper (1964)

Long Valley is an important location for sage grouse and contains the secondlargest concentration in Mono County (U.S. Department of the Interior 1973, p. $v-208)$. The California Department of Fish and Game has long-term population data for all known sage grouse areas in Mono County (see Appendix A).

Few species have more specialized habitat requirements than the sage grouse (Patterson 1952). In winter they feed almost exclusively on leaves of sagebrush (Artemisia tridentata). They also require four different areas during their life cycle: strutting grounds, nesting grounds, brood areas, and 
winter range. The birds are year-round residents in Long Valiey, except during severe winters when they migrate to more sheltered locations east of the KGRA. A large population also occurs in the Bodie Hills to the north of Mono Lake. Because of their specialized requirements, sage grouse are particularly susceptible to habitat losses or alterations. Populations in Long Valley appear to be stable now, following reduction of heavy hunting pressure in 1974 . (Morris Anderson, personal communication). There is presently a two-day hunting season for sage grouse with a one-bird limit.

A three-month study on the effects of a geothermal well drilling operation on sage grouse was conducted in Long Valley during Republic Geothermal, Inc.'s operations in 1976 (Fraser-Smith 1977). A major conclusion was that welldrilling operations, including noise, had no effect on sage grouse behavior beyond $1600 \mathrm{~m}(1760 \mathrm{yd})$ from the well. The lack of major use areas closer than $1600 \mathrm{~m}$ to the well precluded definitive statements about effects of closer well operations. Another conclusion was that sage grouse populations in Long Valley were already under stress from habitat loss and conversion--particularly from overgrazing by cattle.

Another important wildife species in Long Valley is the mule deer. The Casa Diablo deer herd migrates between sumer ranges in the Sierra Nevada and winter ranges to the east of the KGRA. The herd presently numbers about 1000 to 1500 deer (Morris Anderson, personal comunication). Important migration routes pass through Long Valley, and specifically through the "grandfather lands" above Crowley Lake. These routes are typically $1 / 4$ to $1 / 2 \mathrm{mile}(0.4$ to $0.8 \mathrm{~km}$ ) wide, and generally the same from year to year. However, routes to winter ranges may be disrupted by hunters (Morris Anderson, personal communication).

Generally speaking, man should also be considered as part of the biotic component of ecosystems. In Mono-Long Valley this is particularly true. Forests and grasslands, and fish and wildlife populations have formed the base of the region's economy for thousands of years. About $85 \%$ of the economy of Mammoth Lakes and Mono County is currently based on recreation (U.S. Department of the Interior 1973, p. v-216; SWR 1975, p. 34). Recreation use on National Forest land in the Mammoth-Mono Planning Unit of Inyo National Forest totalled nearly 3 million recreation-visitor-days in 1977--where one recreation-visitor-day is equivalent to one person visiting for twelve hours (U.S. Forest Service 1978). Annual recreation use for all of Inyo National Forest is over 5 million recreation-visitor-days, fourth highest of all National Forests (U.S. Forest Service data). Interactions between man and the environment are covered in more detail in our chapters on archaeology and socioeconomics.

\section{KEY ISSUES AND DATA GAPS}

What are the key ecological issues concerning geothermal energy development in Mono-Long Valley? Can the existing data base be used to resolve some of these issues? What additional data are needed to ensure that geothermal development in the KGRA will not be detrimental to the structure and function of existing ecosystems? These questions were addressed at our workshop in Mammoth Lakes on August 10-11, 1978. Answers to them depend in large part on the size and kind of development which may take place, e.g., whether it will be for space heating or electricity generation. The size and nature of the two types of 
development differ significantly in their potential impacts on natural ecosystems. A closed-1oop system for space heating similar to the pilot plant now in operation at Casa Diablo would undoubtedly have fewer ecological effects than an electrical generating station with its attendant well pads, steam gathering lines, power houses, and cooling towers.

Major ecological issues which were developed at our workshop are 1 isted in Table 6 and discussed in the following paragraphs. Included are directeffect issues such as habitat losses from development, and indirect-effect issues resulting from potential air and water quality changes which may affect natural ecosystems. Recommendations for resolving major issues are given in Table 7.

\section{Hot Creek Fish Hatchery}

One of the most critical issues and data gaps concerns hydrothermal relationships in Hot Creek, particularly their importance to operations of Hot Creek Fish Hatchery. Data gaps here involve questions of surface and ground-water flows, water chemistry, and the physiology of fish. For example, the nature of underground connections between geothermal springs used by the fish hatchery and the larger reservoir likely to be tapped by geothermal development are unknown. Disruption of the present surface system could have adverse consequences on the operation of the hatchery if waters were cooled only several degrees (Sorey 1976). Any hot spring changes would likely also affect Hot Creek itself and its biota.

A related issue and data gap concerns the role of water chemistry in the biological production of the fish hatchery and other Hot Creek communities. Are their high productivities simply the result of elevated temperatures from geothermal springs, or do these same springs alter water chemistry enough to be of physiological significance?

\section{Hot Spring Environments}

Geothermal drilling in the 1960 's has been cited as a reason that hot springs dried up in the Casa Diablo area (Smith 1976, p. 20). Some species appear to be specifically adapted to hot spring habitats, but little is known about the basic ecology of surface hot springs and associated ecosystems in Mono-Long Valley. Basic ecological data are needed to characterize the fauna and flora of these areas before development begins.

Habitat Loss to Vegetation and Wildlife

Habitat losses and alterations present another major issue for ecological communities. The ultimate question is whether present-day biolgical communities can coexist with geothermal energy facilities, or whether these facilities will exceed the carrying-capacity of the land and its biota. The answer depends in large part on the size and design of facilities, both of which are presently unknown.

Habitat changes in Long Valley are of particular concern regarding sage grouse populations, deer migration routes, and rare and endangered species. Migration routes and sage grouse use areas are currently known therefore, successful resolution of the issue involves mitigation through appropriate design 
of facilities. Habitats and locations of rare and endangered species are less well known, particularly for areas outside of the "grandfather lands" in Long valley. Soil erosion should not be an especially critical habitat issue because of the surface relief and substrate of areas most likely to be developed. An exception might be siltation of trout streams caused by erosion during large scale construction or road building. Noise could cause effective habitat loss unless adequate mitigation measures are utilized.

In attempting to resolve habitat issues, it is important to consider not only short-term localized effects, but also long-term cumulative effects of development. For example, habitat loss or alteration from one exploratory well may. not be ecologically significant, whereas that from an entire development may be.

\section{Ecologic-Economic Interactions}

Ecological issues are closely related to economics in Mono-Long Valley. Natural ecosystems form the base of the region's recreation-oriented economy. If these ecosystems and the area's natural beauty are degraded, the region's existing economy may also suffer. An important data gap in this respect concerns information and techniques to assess the net benefit of current land use for recreation, timber, grazing, watershed, etc., compared to its use for energy facilities. The economic value of timber sales, grazing allotments, ski lift tickets, etc. can be identified, but it is more difficult to assign dollar values to watershed protection, wildlife, scenery, etc. Westman (1977) has pointed out some of the considerations and difficulties in determining the economic value of natural ecosystems.

Water Quality

Water quality issues are of concern to biological communities. Issues concerning the flow, temperature, and chemistry of hot springs have already been considered. An additional issue involves ecological effects of accidental releases of geothermal fluids--primarily because of their chemical constituents and high temperatures. A somewhat related issue concerns the environmental pathways of potentially toxic trace elements from natural geothermal discharges into Long Valley ecosystems. Knowing such pathways and environmental sinks could help identify especially sensitive or vulnerable ecosystem components. For example, the California Department of Water Resources (1967) estimated that about $16 \%$ (2.4 tons) more arsenic was annually entering Crowley Lake (from natural sources) than was leaving it. Eccles (1976) concluded that no health problems were likely from these elevated arsenic concentrations but the long-term environmental effects are unknown.

Water Availability

Some indirect ecological issues are related to water availability. For example, will increased moisture as a result of water vapor releases from evaporative cooling towers alter native plant commities by creating a more mesic environment? Conversely, will a drier environment be created by falling water tables caused by the withdrawal of geothermal fluids or removal of fresh water for cooling purposes? Natural ecosystems in parts of the KGRA (e.g. Mono Lake) are already being affected by the removal of surface waters. Basic hydrological data and information on the size and design of any project are 
needed to resolve these issues. Mathematical modeling could also be a useful tool.

\section{Atmospheric Emissions}

The potential effects of mineral deposition from cooling towers or well blowouts onto vegetation and soils deserve attention. Boron deposition has been implicated as a possible cause of damage to vegetation near cooling towers at The Geysers (Leitner 1978, p. 13). Such deposition in Mono-Long Valley could be important because of relatively high concentrations of arsenic, boron and fluoride in geothermal fluids (see Chapter 2). Data which are needed to determine potential effects of these and other atmospheric emissions include chemical characterization of the geothermal reservoir at depth, and knowledge of development plans.

\section{$\underline{\text { Values }}$}

One final point should be made with respect to issues. Where questions of values and priorities are involved, the issues may not be resolvable through short-term research and further data acquisition. Issues involving aesthetics, "the quality of life," and the value of rare and endangered species are examples. This, however, does not imply that such issues should be ignored.

\section{TABLE 6}

\section{MAJOR ECOLOGICAL ISSUES}

1. Potential changes in temperatures, flow rates, and chemical composition of thermal springs. Effects of such changes on:

a) Hot Creek Fish Hatchery

b) natural biota of Hot Creek, especially fish populations

c) biotic communities adapted to hot spring environments

2. General habitat changes caused by noise and physical disturbance from construction of well pads, roads, power plants, cooling towers etc. Effect of such habitat changes on:

a) areas which are unique or of special concern, such as Hot Creek, Mono Lake, pumice flats, and alkali flats

b) distribution and abundance of plants and animals, including sage grouse and rare and endangered species

c) migration routes of deer and non-game species

d) accelerating soil erosion 
3. Impact of development on the economic value of existing natural ecosystems, including:
a) potential harm to the general recreation base of the region for skiling, fishing, hunting, camping, hiking etc.
b) net benefit of current land use versus its conversion to energy production
c) aesthetics

4. Effects on biota from changes in water quality and quantity, including:
a) effects of accidental fluid discharges with relatively high As, $B$, and $F$ concentrations
b) depletion of surface and ground waters by the withdrawal of
geothermal fluids or additional waters for cooling purposes
c) potential for increased precipitation from cooling tower conden- sate

5. Potential adverse effects on biota from atmospheric emissions, including:
a) deposition of boron and other elements from cooling tower drift

b) H $S$ and other non-condensable gases

c) noise

\section{TABLE 7}

\section{RECOMMENDATIONS}

The following general and specific recomendations were developed at our workshop after discussion of the key issues, existing data base, and data gaps.

\section{General Recommendations}

Existing data should be used and future studies planned with the following goals in mind:

1. Preventing disturbance or destruction of unique and critical habitats.

2. Mitigating general habitat effects from geothermal development. These inciude:

a) effects on hot springs (flow, temperature, and chemistry) 
b) habitat loss from surface disturbance

c) effective habitat loss from noise

d) barriers to wildlife movements and migrations

e) habitat changes from weather modification

f) air and water emissions (heavy metals, boron, $\mathrm{H}_{2} \mathrm{~S}$ )

g) impacts resulting from the use and availability of drilling and/or cooling water

Specific Recommendations

1. A hydrologic/geologic study should be conducted to determine the potential impact of geothermal fluid withdrawal on the integrity of hot springs, particularly those in the Hot Creek area. The U.S. Geological Survey in 1977 proposed drilling two 200-meter (650 ft.) test wells west of the hatchery to determine any hydrological connections between fish hatchery springs and the larger geothermal reservoir, but this work was not done.

2. A thorough inventory should be made of rare and endangered plant and animal species in the KGRA. This should be done early to avoid any potential siting conflicts for proposed developments. The U.S. Forest Service is currently preparing environmental sensitivity maps for the so-called "grandfather lands" in Long Valley which will include, among other things, known locations of sensitive species and critical habitats.

3. A program should be instituted to establish "baseline conditions" and to monitor the effects of development on hot springs (flow, temperature and chemistry), and the effects of trace element emissions (particularly cooling tower drift) on soil and plant chemistry. Lease stipulations should include the need for such monitoring and a provision for reevaluation of the lease if monitoring results show adverse impacts from development. The California Department of Fish and Game does continuous temperature monitoring and occasional chemical monitoring at six hot springs which are used by Hot Creek Fish Hatchery and at one station in Hot Creek (see Appendix A).

4. Basic ecological data should be collected on the kinds of organisms (plants, animals, and microbes) adapted to, and perhaps dependent upon, hot spring environments.

5. There is a need to determine the amounts and sources of surface and ground water which can be used consumptively by geothermal projects without adversely affecting existing aquatic or terrestrial ecosystems. 


\section{ACKNOWLEDGMENTS}

The discussions of the ecology section at our workshop were led by Robert Giacosie and Phil Leitner. Notes taken during these discussions provided the base for the issues and recommendations contained in this chapter. Although a complete list of discussion participants was not recorded, the following individuals were present: Mary DeDecker (Independence), Robert Giacosie (California Energy Commission), Thomas Jenkins (June Lakes), John Koranda (Lawrence Livermore Laboratory), Andrea Lawrence (Mammoth Lakes), Phil Leitner (St. Mary's College), Phil Pister (California Department of Fish and Game), Ronald Powell (California Department of Fish and Game), William Rhoads (EG \& G), Marjorie Sill (Sierra Club), Glenn Suter (Oak Ridge National Laboratory), David Winkler (Mono Basin Research Group), and Darrell Wong (California Department of Fish and Game). Complete affiliations are given in Appendix IV to the report.

The identification of existing data was aided by the following individuals: Morris Anderson (California Department of Fish and Game), Frank Daniels (Bureau of Land Management), M. DeDecker, John Deinstadt (Cal ifornia Department of Fish and Game), John Derby (U.S. Forest Service), Tom Griggs (California Native Plant Society), Robert Iselin (Hot Creek Fish Hatchery), Harry Leland (U.S. Geological Survey), Charles McDonald (U.S. Forest Service), John Melack (University of California, Santa Barbara), Marilyn Meyers (Bureau of Land Management), P. P.ister, R. Powell, 011 ie Sapousek (U.S. Forest Service), Jerry Stefferud (U.S. Forest Service), William Thomas (University of California, San Diego), and D. Winkler.

I thank the following people for critical review of this chapter: $M$. Anderson, Barry Boudreau and associates (U.S. Geological Survey, Menlo Park), M. Dedecker, J. Deinstadt, R. Giacosie, P. Leitner, C. McDonáld, J. Melack, P. Pister, R. Powell, W. Smith (Union Oil Company), J. Wickser (Los Angeles Department of Water and Power), S. Willard (California Energy Commission), and D. Winkler. 


\section{REFERENCES CITED}

Aldrich, J. M. 1912. The biology of some western species of the dipterous genus Ephydra. J. New York Entomol. Soc. 20:77-99.

Anderson, D. N. and R. G. Bowen. 1974. Proceedings of the workshop on environmental aspects of geothermal resources development. Report NSF-RA-E-74-071. Springfield, Va., National Technical Information Service, $123 \mathrm{p}$.

Armstrong, M. 1972. Wildlife. In Facing the future: Five alternatives for Mammoth Lakes; final report of the Mammoth Lakes/UCLA project, pp. 127-138. Los Angeles, University of California, School of Architecture and Urban Planning, and Environmental Science and Engineering Program, $243 \mathrm{p}$.

Baas, J., F. D. Westerdahl, and R. L. Perrine (eds.). 1976. Non-point source water quality monitoring, Inyo National Forest, 1975. California Water Resources Center Contribution No. 156, University of California, Davis.

Bowen, R. G. 1973. Environmental impact of geothermal development. In Geothermal energy (P.F. Kruger and C. Otte, eds.), pp. 197-215. Stanford, Calif., Stanford University Press.

Bowen, S. T. 1964. The genetics of Artemia salina. IV. Hybridization of wild populations with mutant stocks. Biol. BuTl. 126:333-344.

California Department of Fish and Game. 1975. Salmonid stream study, Job No. 4 (Study VI), Hot Creek wild trout research, July 1974-June 1975.

California Department of Fish and Game. 1978. At the crossroads 1978. A report on California's endangered and rare fish and wildlife. Sacramento, The Resources Agency, 103 p.

California Department of Water Resources. 1967. Investigation of geothermal waters in the Long Valley area, Mono County. $141 \mathrm{p} .+7 \mathrm{pl}$.

. Eccles, L. A. 1976. Sources of arsenic in streams tributary to Lake Crowley, California. U.S. Geol. Survey, Water-Resources Investigations 76-36, 39 p.

Fairbridge, R. W. (ed.). 1966. The encyclopedia of oceanography. New York, Reinhold Publ. Co., 1021 p.

Fisher, W. K. 1902. A trip to Mono Lake, ornithological and otherwise. The Condor 4:3-11.

Fraser-Smith, E. B. 1977. The effect of drilling a geothermal well on the behavior and reproduction of sage grouse. Prepared for Republic Geothermal, Inc., by Enviros, Los Altos, Cal if., $76 \mathrm{p}$. 
Goldsmith, M. 1971. Geothermal resources in California: Potentials and problems. California Institute of Technology, EQL Report No. 5, 45 p.

Heilbrun, L. H, and the CBC Regional Editors. 1978. The seventy-eighth Audubon Christmas Bird Count. Amer. Birds 32:415-911.

Hess, H. 1976. Geothermal energy prospects and limitations. Sierra Club Bulletin, Nov./Dec.:9-12.

James A. Roberts Associates, Inc. 1973. Preliminary natural resource baseline and environmental sensitivity analysis for Mammoth. In Monoplan phase 2: Environmental background reports. South Pasadena, Calif., Monoplan Associates, $111 \mathrm{p}$.

Kruger, P. 1976. Geothermal energy. Annu. Rev. Energy 1:159-182.

Leitner, P. 1978. An environmental overview of geothermal development: The Geysers-Calistoga KGRA. Volume 5. Ecosystem quality. Lawrence Livermore Laboratory Report UCRL-52496, 52 p.

Lewis, R. E. 1974. Data on wells, springs, and thermal springs in Long Valley, Mono County, California. U.S. Geol. Survey, open-file report, 52 p.

Los Angeles Department of Water and Power. n.d. Los Angeles water rights in the Mono Basin and the impact of the Department's operations on Mono Lake.

Mason, D. T. 1967. Limnology of Mono Lake, California. Univ. Calif. Publ. 2001. 83:1-110.

McFadden, J. T. and W. L. Cooper. 1964. Population dynamics of brown trout in different environments. Physiol. Zool. 4:355-363.

Miller, R. R. 1973. Two new fishes, Gila bicolor snyderi and Catostomus fumeiventris, from the Owens River basin, California Univ. Mich. Mus. Z001. Occ. Pap. 667:1-19.

Mono Lake Comittee of the Santa Monica Bay Audubon Society. 1978a. Newsletter $1(2): 1-13$.

Mono Lake Committee of the Santa Monica Bay Audubon Society. 1978b. Mono Lake: Its uncertain future. Oakland, Calif., P.0. Box 2764, 17 p.

Oregon Wildlife Comission. 1974. Ecology and management of brown trout in Little Deschutes River, Oregon. Fishery Research Report No. 8.

Patterson, R. L. 1952. The sage grouse in Wyoming. Wyoming Game and Fish Commission, $341 \mathrm{p}$.

Powell, W. R. (ed.). 1974. Inventory of rare and endangered vascular plants of California. California Native Plant Society, Special Publication No. 1. 
Reimers, N., J. A. Maciolek, and E. P. Pister. 1955. Limnological study of the lakes in Convict Creek Basin, Mono County, California. U.S. Fish and Wildlife Service Fishery Bulletin, Vol. 56, Fishery Bulletin 103.

Rowell, G. 1978. Mono Lake: Silent, sailless shrinking sea. Audubon $80(2): 102-106$.

Scholl, D.W., and W.H. Taft. 1964. Algae, contributors to the formation of calcareous tufa, Mono Lake, California. J. Sed. Petrol. 34:309-319.

Sims, A.V., and W.C. Racine. 1977. Feasibility of geothermal space/water heating for Mammoth Lakes Village, California. Final report for period September 1976-September 1977. Prepared for the Department of Energy, Pasadena, Calif., The Ben Holt Co., 123 p.

Smith, G.S. (ed.). 1976. Marmoth Lakes Sierra, a handbook for roadside and trail, 4th ed. Palo Alto, Calif., Genny Smith Books, 147 p.

Smith and Williams, Recreation Consultants. 1973. Manmoth recreation and recreational accommodations. In Monoplan phase 2: Environmental background reports. South Pasadena, Calif., Monoplan Associates, 127 p.

Sorey, M.L. 1976. Potential effects of geothermal development on springs at the Hot Creek Fish Hatchery in Long Valley, Mono County, California. U.S. Geol. Survey open-file report 75-637, 8 p.

SWR. 1975. Draft environmental statement for Monoplan for Mammoth. Sausalito, Calif., 245 p. + App.

Twain, M. [Clemens, S.L.]. 1872. Roughing it. Hartford, Conn., American Publ. Co., $591 \mathrm{p}$.

U.S. Department of Energy. 1978. Environmental readiness document: Hydrothermal electric and direct heat. Report DOE/ERD-0005, 26 p. +2 App.

U.S. Department of the Interior. 1973. Final environmental impact statement on the federal geothermal development program. Vol. II, V-157 to V-297.

U.S. Department of the Interior, Bureau of Land Management, Bakersfield District. 1978. Plan and program update. April 30, 1978, 4 p.

U.S. Environmental Protection Agency. 1977. Western energy resources and the environment: Geothermal energy. Report EPA-600/9-77-010, $103 \mathrm{p}$.

U.S. Fish and Wildlife Service. 1976. Endangered and threatened species. Plants. Federal Register 41(117):24523-23572, June 16, 1976 .

U.S. Fish and Wildlife Service. 1979. List of endangered and threatened wildlife and plants. Federal Register 44(12):3635-3654, Wednesday, January $17,1979$.

U.S. Forest Service. 1978. Draft environmental statement of land management alternatives for the Mammoth-Mono Planning Unit. 171 p. + 8 App. 
U.S. Geological Survey. 1976. Environmental analysis for three proposed deep exploration holes on Lease CA-963, Republic Geothermal, Inc.

University of California, Los Angeles. 1972. Facing the future: Five alternatives for Marmoth Lakes; final report of the Mammoth Lakes/UCLA project. School of Architecture and Urban Planning, and Environmental Science and Engineering Program, 243, p.

Westman, W. E. 1977. How much are nature's services worth? Science 197:960964.

Whittaker, R. H. 1975. Communities and ecosystems, 2nd ed. New York, Macmillan Publ. Co., Inc., $385 \mathrm{p}$.

Winkler, D. W. (ed.). 1977. An ecological study of Mono Lake, California. University of California, Davis, Institute of Ecology Publication No. $12,184 \mathrm{p}$.

Woodward-Clyde Consultants. 1977. Exploratory geothermal well drilling operations at Long Valley, California. Environmental data statement prepared for Union $0 i 1$ Company of California. San Francisco, Calif., Woodward-Clyde Consultants, ca. 78 p. + App. 
APPENDIX A: ECOLOGICAL DATA SOURCES

Following is a summary and assessment of sources of ecological data for $\longrightarrow$ Mono-Long Valley KGRA.

Reimers et al. (1955)

One of the earliest baseline surveys was a limnological study conducted by the U.S. Fish and Wildlife Service on ten alpine and montane lakes in Convict Creek Basin (Reimers et al. 1955). All ten lakes drain into the KGRA, but only Convict Lake is within the KGRA boundaries. The ten lakes represent a range of conditions in altitude, substrate materials, area, depth, and morphometry. Numerous comparative data were collected during the summers of 1950 and 1951 on zooplankton, benthic fauna, and trout populations. Analyses of food habits of brook, brown and rainbow trout were based on stomach contents of 979 trout; benthic invertebrates were sampled with an Ekman dredge at regular intervals along several transects in each lake; and vertical plankton hauls were made from all levels to the surface of the deepest part of each lake. Abiotic data were also collected, including information on lake morphometry, bottom types, sumer temperature characteristics, transparency, and water chemistry. Although this study is about twenty-five years old, it is still a major source of limnological data.

Mason (1967)

This report contains the results of doctoral thesis research on the limnology of Mono Lake. Biological data were restricted mainly to numbers and diversity of plankton species, and some measurements of primary productivity based on six different methods. Abiotic data included lake morphometry, hydrologymeteorology, thermal-hydrodynamics, and water chemistry, some of which were from secondary sources. This report and one by Winkler (1976) are presentiy the major sources of ecological data for Mono Lake.

UCLA (1972)

A multi-disciplinary planning study of the Mammoth Lakes area by the University of California, Los Angeles (1972) included a chapter on wildlife (Armstrong 1972). Few original ecological data were presented, but recommendations for wildlife and habitat preservation were made on the basis of existing data--primarily from U.S. Forest Service sources.

James A. Roberts Associates, Inc. (1973)

This environmental baseline report was part of the Monoplan, a cooperative planning study between Mono County and the U.S. Forest Service. The study area covered about $300 \mathrm{mi}^{2}\left(777 \mathrm{~km}^{2}\right)$ near Mamnoth Lakes, of which about 260 $\mathrm{mi}^{2}\left(673 \mathrm{~km}^{2}\right)$ were in the southern part of the KGRA. Baseline data were summarized, mainly from previously-existing sources, for soils, climate, hydrology, major vegetation types, and wildlife--including rare and endangered animal species. Original data sources are not always identified, e.g. rare and endangered species data. Baseline maps were prepared for each of the above resources (2000 ft scale) from a combination of field inventories and aerial photography. Maps are available from the Mono County Planning Commission. 


\section{U.S. Department of the Interior (1973)}

The final environmental impact statement for the federal geothermal development program (U.S. Department of the Interior 1973) contains an entire chapter on Mono-Long. Valley KGRA. Included in it are descriptive sumnaries of existing biological and other resources in the KGRA. Much information is included, but data sources are not always adequately identified.

\section{Powel1 (1974)}

In 1974, the California Native Plant Society (CNPS) published an inventory of rare and endangered plant species in California (Powell 1974). The publication summarized original data from the work of amateur and professional botanists. Information for each species included the vernacular name, flowering period, degree of rarity, endangerment, vigor and general distribution, and location by county and U.S. Geological Survey topographical quadrangle maps. Known locations of plants in the KGRA can be identified on $15^{\prime}$ topographic maps by the CNPS, currently located at the Institute of Ecology, University of California, Davis.

\section{SWR (1975)}

The draft environmental impact report for the Monoplan (SWR 1975) contains descriptive summaries from secondary sources. Data sources are not always identified, e.g. rare and endangered plant species data. Many of the environmental statements are based on information presented by James $A$. Roberts Associates, Inc. (1973).

Baas et al. (1976)

This water quality study conducted by the Environmental Science and Engineering Program at UCLA contains data on bacterial and algal populations from three sites in the KGRA: Horseshoe Lake, Hot Creek, and Sherwin Lakes. Numbers of coliform bacteria were determined with a Millipore memblane filtration technique followed by incubation in a growth medium, while qualitative estimates of algal species composition were obtained by microscopic examination of concentrated samples.

Smith (1976)

This book provides a valuable and very readable introduction to the geological, natural, and human history of the region included in the KGRA. While it is based mostly on secondary sources, it summarizes considerable information.

\section{U.S. Geological Survey (1976)}

Some ecological data are presented in various reports relating to geothermal drilling activities. For example, the U.S. Geological Survey (1976) prepared an environmental analysis for Republic Geothermal Inc.'s geothermal drilling in Long Valley. The descriptive summaries and quantitative data appear to be based mainly on existing sources, particularly Monoplan reports and the environmental impact report for the federal geothermal development program (U.S. Department of the Interior 1973). 


\section{Fraser-Smith (1977)}

An additional study related to Republic's drilling operations is described by Fraser-Smith (1977). The purpose of the three-month study was to observe the behavior of sage grouse during construction and drilling for a geothermal well, and to determine any adverse effect of such activity on the reproductive cycle of sage grouse. The study area encompassed $32.5 \mathrm{~km}^{2}$ (12.5 mi2) within a circle of radius $3.2 \mathrm{~km}$ ( $2 \mathrm{mi})$ centered on the well site in Long Valley ( $T$. 3S., R. 29E., Sec. 29, S.E. 1/4). Measurements and observations were made on human activity, noise levels, weather, vegetation, sage grouse strutting grounds, pellet counts and tracks, flushed birds, nest searches, and brood counts. Human activity was rated subjectively on a 0 to 5 scale. Noise measurements were made with an ambient noise meter at distances of 180,360 , and $720 \mathrm{~m} \mathrm{(200,400}$ and $800 \mathrm{yds})$ north, south, east, and west of the well site. Noise measurements were also made at two strutting grounds and at Big Alkali Lake, $2200 \mathrm{~m}(2,420 \mathrm{yds})$ away. Plant species were recorded along $60 \mathrm{~m}$ $(200 \mathrm{yd})$ transects. Detailed observations of sage grouse behavior were made, including numbers of male and female sage grouse arriving at and departing from two active strutting gounds, direction of flight, maximum count for each ground, and peak time of strutting ground attendance. Pellet counts and tracks were identified along transects to determine roosting and feeding habits. Flushed birds, nests, and brood counts were noted on these transects. Comparisons were made with long-term sage grouse data collected by the California Department of Fish and Game.

\section{Woodward-Clyde Consultants (1977)}

Another environmental data statement was prepared by Woodward-Clyde Consultants (1977) for Union 0il Company's three proposed deep geothermal wells in Long Valley. While the report contains mostly descriptive information from secondary sources, U.S. Forest Service biological data are presented which are not given in other environmental reports.

\section{Sims and Racine (1977)}

This report contains a preliminary environmental assessment which was prepared by Southern California Edison Company (SCE) for a geothermal district heating system proposed for Casa Diablo and Mammoth Lakes. Descriptive information was presented on vegetation and wildlife. Some original data were collected during a three-day biological survey conducted by SCE in July 1974, and during a two-day survey conducted in April 1977. The 1974 survey included 102 trapping nights for small marmals, and some observations on reptiles and birds. Survey methods and sampling locations were not given in the report.

\section{Winkler (1977)}

This report contains the results of a student-originated project on the ecology of Mono Lake sponsored by the National Science Foundation. Although field research was limited to only three months, original data were collected on all trophic levels of the lake ecosystem. Many data from secondary sources were also included. Baseline and experimental data were collected on aquatic and terrestrial vegetation, aquatic and shore invertebrates, bird populations, and biological production. Photosynthesis and cholorphyli were measured by carbon-14 and spectrophotometric methods respectively. 
Bureau of Land Management

The Bishop office of the Bureau of Land Management (BLM) is proceeding on a comprehensive Managenent Framework Plan to inventory mineral resources, soils, vegetation, wildi ife, and cultural resources in the Benton/Owens Valley Planning Unit, an area encompassing almost 600,000 acres (U.S. Department of the Interior 1978). Included in this inventory are all BLM lands in the KGRA ( 92,000 acres). Maps are being prepared at a scale of about 1 in. per mi. for soils and major vegetation types, based on aerial photography and some ground work (Frank Daniels, personal comunication). Because of the large area involved, few locations can be studied in detail. Wildlife data included in the inventory are historical museum records (primarily early collections from the Museum of Vertebrate Zoology, University of California, Berkeley, and the Cleveland Museum of Natural History), as well as data from recent field studies (Marilyn Meyers, personal communication). Recent BLM field studies included small mamal trapping in a representative site for each of the major wildlife habitats in the Planning Unit, using a combination of 300 to 500 small Sherman live traps and snap traps for three consecutive nights. About seven sites were located on BLM lands in the northern part of the KGRA. Breeding bird surveys were conducted under contract in twenty-one habitat sites in the Planning Unit in May and June 1978, using one-mile transect counts. Data for reptiles and amphibians were based mainly on historical records. Limited sampling of invertebrates in BLM sections of Hot Creek and Little Hot Creek was done for one day.

California Department of Fish and Game

The California Department of Fish and Game is the major source of fish and wildlife data for the KGRA. Of particular interest was a four-year program (1973-1976) on trout populations in Hot Creek. Trout populations were studied in a $0.9 \mathrm{mi}(1.4 \mathrm{~km})$ section of Hot Creek from about 200 yds (183 $\mathrm{m})$ above the swiming area footbridge to the downstream boundary of Hot Creek Ranch (John Deinstadt, personal communication). Fish populations were estimated by mark and recapture one week before opening day (April) and after the fishing season closed (October). The purpose of the study was to determine the effect of reducing the angling limit in 1974 from 10 to 2 fish per day. A second part of this study concerned experimental fingerling stocking. In 1972-1973 marked trout fingerling were added to Hot Creek and their contribution to the native population studied. Information on these studies is available in progress reports, and a management report on Hot Creek is scheduled for completion in the summer of 1979 (John Deinstadt, personal communication).

The California Department of Fish and Game annualiy collects data for all known sage grouse strutting grounds in Mono County (Morris Anderson, personal communication). Data extend back to the mid-1950's, with extensive information available beginning in 1959. Data are gathered on the number of males at strutting grounds, brood counts, and hunting pressure. Males are counted in spring, while females and young are counted later in the summer. Data must be interpreted carefully because of these differences, and because of varying efforts annually expended on data collection. Some data are also available for the Casa Diablo deer herd, including migration routes, hunting kills and herd composition. Nesting sites for raptors have also been identified. 
Data on rare and endangered species of fish and wildlife are also available from the California Department of Fish and Game. For example, the Department publishes a biennial report on the status of California's endangered and rare fish and wildlife. The most recent report (California Department of Fish and Game 1978) contains information on the descriptions, distributions, status, and management actions and recomendations, and literature references for five species found in the KGRA which are identified as rare or endangered by the State of California. The Department has also recently completed a map of areas of special biological importance for Mono County (scale: 2 in. per mi.), which includes information on deer migration routes and fawning areas, sage grouse strutting grounds, wolverine sightings, etc. (Morris Anderson, personal comunication). Copies are on file in Sacramento.

Hot Creek Fish Hatchery, operated by the California Department of Fish and Game, maintains production data on trout raising operations. The hatchery also collects potentially important temperature and chemical data on the geothermal springs which it utilizes in its operations (Robert Iselin, personal communication). One continuous recording thermograph is located at each of the six geothermal springs the hatchery uses, and an additional thermograph is located in Hot Creek downstream from Hot Creek Ranch. Chemical analyses of hatchery spring waters are made on an irregular basis. Results of these analyses were reported in detail by Lewis (1974).

\section{U.S. Forest Service}

Data are available on critical habitats and plant and animal species inhabiting the KGRA. Much of this information, however, is based on general knowledge of habitat types and locations, sightings, and collections by forest Service personnel. There have been no extensive or systematic animal surveys in the KGRA (Jerry Stefferud, personal communication). Most data on animals are for game species such as sage grouse and deer. Some of these data are based on California Department of Fish and Game surveys. Data on non-game species are mainly restricted to raptors and a species of chipmunk Eutamias speciosus). Rare and endangered plant species have been identified for certain specific areas, e.g. Smokey Bear Flats. Many of the ecological baseline data pertaining to the Long Valley area are currently being assembled in an environmental assessment for geothermal leasing. This document is scheduled for completion in spring 1979. Part of the environmental assessment will include maps for the "grandfather lands". in Long Valley which identify, among other things, sensitive species and critical habitats (011ie Sapousek, personal communication). These will be based on Forest Service data as well as data collected by individuals and other agencies.

\section{Sierra Nevada Aquatic Research Laboratory (SNARL)}

Dr. John Melack (University of California, Santa Barbara) is in the second year of a long-term investigation of the Mono Lake ecosystem (personal communication). During the first year, seasonal dynamics and spatial distribution of phytoplankton and brine shrimp were described and nutrient concentrations measured. The next phase will determine: (1) the influence of salinity increases on the reproductive success of the aquatic biota, (2) the reproductive, grazing and nutrient cycling rates of brine shrimp, and (3) growth rates and nutritional needs of the phytoplankton. This research is being funded by the University of California and the National Geographic Society. 


\section{U.S. Geological Survey (Menlo Park)}

Dr. Harry Leland (Water Resources Division) is conducting a study on the response of aquatic biological communities in Convict Creek to low levels of copper $(1-30 \mu \mathrm{g} / 1)$. The study began in June 1977 and is expected to cont inue until the fall of 1980. This is a basic blology study utilizing the experimental field facilities at Convict Creek (SNARL). Responses in both the structure and function of the biological community are being measured, with emphasis on benthic invertebrates. Other organisms to be studied include fish, periphyton, protozoans, and rotifers. Abiotic measurements will include both physical and chemical measurements of the stream. Copper is being added continuously except during winter, and sampling occurs every 4 to 6 weeks from about July through October.

\section{Individuals and Environmental Groups}

Many individuals maintain an active interest in the natural history of the region. These people are often long time residents of the area and very valuable sources of information. Environmental groups are very active in the area as well. The applicability of the California Environmental Quality Act of 1970 (CEQA) to private activities for which a permit or other entitlement is required is based on a landmark California Supreme Court decision of a case involving condominium construction in Mammoth Lakes (Friends of Mammoth $v$. Board of Supervisors of Mono County). Hess (1976) discussed the environmental concerns of the Sierra Club with respect to geothermal energy development in sensitive regions such as Long Valley. The National Audubon Society has been active in publicizing and attempting to ameliorate the environmental effects of water diversions from Mono Lake (Mono Lake Comittee 1978b, Rowell 1978). The annual Audubon Christmas Bird Count also includes two sites in the KGRA-Mammoth Lakes and Mono Lake (Heilbrun et al. 1978, pp. 868, 870). Records from Mammoth Lakes begin in 1967, and from Mono Lake in 1977. 

Chapter 7

NOISE OVERVIEW

Philip Leitner

Biology Department

Saint Mary's College

Moraga, Californja 


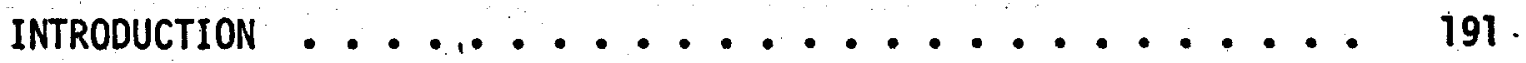

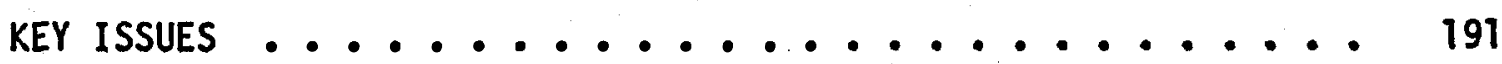

EXISTING DATA BASE ...................... 191

Geothermal Noise Sources . . . . . . . . . . 192

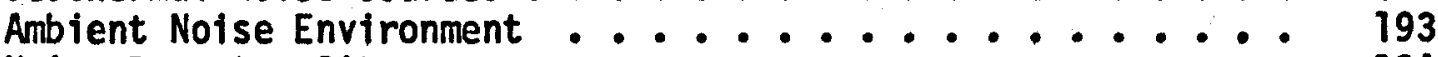

Noise Receptor Sites ................ 194

Noise Propagation Models ...................... 194

Noise Criteria and Standards ................... 195

Cormunity Noise ................... 195

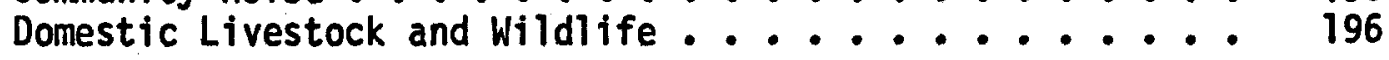

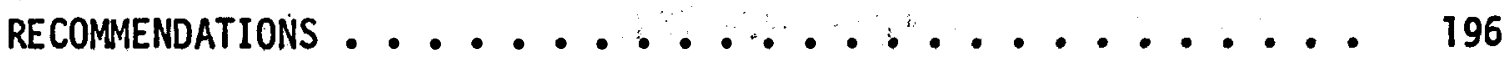

Source Term Measurements . . . . . . . . . . 196

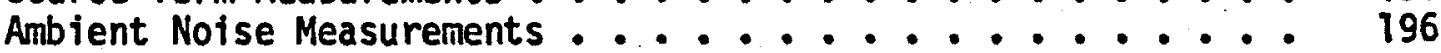

Noise Receptor Sites ................ 197

Noise Criteria and Standards ............. 197

REFERENCES CITED . . . . . . . . . . . . . 198 


\section{INTRODUCTION}

The development and utilization of geothermal energy resources, like many other industrial operations, can be a source of unwanted sound. Geothermal industry noise emissions have become a significant environmental issue at The Geysers-Calistoga Known Geothermal Resource Area in northern California (Leitner 1978). In this KGRA; major geothermal development projects have been constructed or proposed in proximity to a number of small residential communities. Some local residents who have chosen The Geysers area for its recreational and retirement values object to increased noise levels resulting from the truck traffic, the drilling of geothermal wells, and the venting of large quantities of superheated steam.

Therefore, it is important to evaluate the potential for environmental noise problems prior to large-scale geothermal development at Mono-Long Valley KGRA. This chapter will identify key issues relating to noise effects. It will describe existing data that may be useful in resolving these issues: ambient noise conditions within the region, geothermal noise sources to be expected, types of sensitive noise receptors, and any applicable regulations or standards. Finally, it will outline the additional information needed to help ensure that geothermal development can proceed without creating unacceptable noise impacts.

\section{KEY ISSUES}

It seems likely that noise emissions in Mono-Long Valley KGRA will be of moderate intensity compared to those experienced during development and operation of the vapor-dominated geothermal field at The Geysers. Nevertheless, the existing quiet ambient conditions, the lack of other industrial noise sources, and the sensitivity of many visitors and residents to changes that might detract from the natural setting suggest that potential noise effects should receive serious consideration. The following issues have been identified:

1. What noise levels are likely to be associated with the various stages of the geothermal development process in Mono-Long Valley KGRA?

2. What will be the effects on local communities and sensitive landuses?

3. What will be the effects on wildlife and domestic animals?

4. Are new noise regulations or special noise control technologies required?

\section{EXISTING DATA BASE}

The information needed to adequately address these issues includes quantitative data on geothermal noise sources, characterization of ambient noise conditions, the locations of proposed facilities and existing receptors, and noise propagation models appropiate to the terrain and meteorological properties of the area. With these data, it is possible to predict the impacts that geothermal projects will have on the noise environment at particular receptor sites and to make recommendations for such noise control measures and other mitigations as may be required. 
Geothermal Noise Sources

Although very little noise information is available for geothermal industry operations in the Mono-Long Valley area, extensive studies of noise emissions have been carried out at The Geysers-Calistoga KGRA in northern California (Atlantis Scientific 1975; 1976; Bush 1976, 1977; ECOVIEW Environmental Consultants 1977; Environmental Impact Planning Corporation 1977; Sociotechnical. Systems, Inc. 1977). Wells drilled into the vapor-dominated reservoir at The Geysers produce superheated steam at high pressure. The jet noise which results when there is large-scale venting to the atmosphere has been the source of the majority of community complaints (IIlingworth 1976; Leitner 1978). Sound pressure levels (SPL) over $120 \mathrm{~dB}(A)$ have been recorded at $15.2 \mathrm{~m}(50 \mathrm{ft})$ from well-venting operations and the noise can be heard at distances of $3.2-4.8 \mathrm{~km}$ (2-3 mi). (I11ingworth 1976, Timons and Whitescarver 1978). Noise abatement measures have been successful in reducing the frequency of venting episodes and in effectively silencing certain venting procedures, but additional work is needed to bring all sources under acceptable control (Leitner 1978; Whitescarver 1978).

Because the geothermal reservoirs in Mono-Long Valley KGRA are liquid-dominated, no venting of superheated steam should occur. Wells could be completely. shut-in when not producing, eliminating the need to release geothermal fluid. Furthermore, no venting should be necessary when wells are put back into production. Liquid-dominated geothermal fields can therefore be developed and operated without the problem of very high noise emissions. Major noise sources should not exceed $95 \mathrm{~dB}(A)$ at $15.2 \mathrm{~m}(50 \mathrm{ft})$ and standard noise control measures are available for these sources if required.

A summary of noise sources expected to accompany geothermal resource development in the Mono-Long Valley area is given below, along with typical SPL ranges.

1. Road and Site Preparation. -- Especially during the exploration and field development stages, heavy earth-moving equipment is used to prepare roads, drill pads, sumps, and sites for the power plant and other facilities. Data from the EPA document PB 206717 suggest a $S P L$ range of $70-95 \mathrm{~dB}(\mathrm{~A})$ at $15.2 \mathrm{~m}(50 \mathrm{ft})$ (U.S. Environmental Protection Agency 1971a).

2. Well Drilling. -- Drilling operations begin with exploration and continue through the field development stage. Make-up wells must be drilled periodically during the production stage to replace the original wells whose yield has declined. The dominant noise sources associated with drilling are the large diesel engines which power the rotary rig and mud pumps. Typical SPL during drilling when mud is used as the circulating medium ranges from 75 to $85 \mathrm{~dB}(\mathrm{~A})$ at $15.2 \mathrm{~m}$ $(50 \mathrm{ft})$ (Whitescarver 1978). SPL of about $62 \mathrm{~dB}(A)$ was measured at $182.4 \mathrm{~m}(200 \mathrm{yd})$ from a large rotary drill rig in Long Valley (Fraser-Smith 1977). Compressed air is routinely used as a circulation medium in the final phase of drilling at The Geysers; the large compressors and the release of air to atmosphere can be troublesome noise sources with $S P L$ up to $5 \mathrm{~dB}(A)$ above that recorded for mud drilling (Whitescarver 1978). Since this procedure is not extensively used in liquid-dominated reservoirs, it should not be of concern in the Mono-Long Valley KGRA. 
3. Production Testing. -- The process of flowing geothermal wells to test production capability begins in the exploration stage and will occur periodically for the life of the field as new make-up wells are drilled Data from Imperial Valley in California suggest that SPL during this operation should be below $90 \mathrm{~dB}(\mathrm{~A})$ at $15.2 \mathrm{~m}$ ( $50 \mathrm{ft}$ ) ( $\mathrm{P}$. Leitner, unpublished data).

4. Facilities Construction. -- Construction of a power plant, pipelines, and transmission lines involves the use of many standard pieces of heavy motorized equipment. The resulting SPL can be estimated at 70-95 $\mathrm{dB}(\mathrm{A})$ at $15.2 \mathrm{~m}(50 \mathrm{ft})$ by reference to the EPA document PB 206717 (U.S. Environmental Protection Agency 1971a). Construction of facilities for direct heat applications should result in similar levels of noise emissions.

5. Operation of Geothermal Field and Power Plant. -- The noise emission characteristics of geothermal power plants, including turbine building, cooling tower, and steam jet ejector system, are well-documented and adequate data are readily available. SPL of 75-85 $\mathrm{dB}(\mathrm{A})$ are typical at $15.2 \mathrm{~m}$ (50 ft) from the cooling tower, the dominant noise source (Bush 1977. Pacific Gas and Electric Company 1977)." Other potential noise sources are the flash units in which a portion of the geothermal fluid is allowed to flash to steam. These units may be located at the well heads or near the turbine building, although the exact design will depend on the electric generation technology used. SPL at $15.2 \mathrm{~m}$ (50 $\mathrm{ft}$ ) from a flash unit undergoing testing in Imperial Valley was measured at $85 \mathrm{~dB}(A)$ ( $P$. Leitner, unpublished data). Downhole pumps required to produce the geothermal fluid and reinjection pumps used to dispose of residual liquids should be powered by electric motors; these motors are not expected to be significant noise sources.

6. Vehicular Traffic. -- Auto and truck traffic is an important source of noise throughout the life of any geothermal project, with maximum $S P L$ ranging from $70-95 \mathrm{~dB}(\mathrm{~A})$ at $15.2 \mathrm{~m}(50 \mathrm{ft})$ depending on the type of vehicle (U.S. Environmental Protection Agency 1971b).

\section{Ambient Noise Environment}

The Mono-Long Valley region is sparsely populated and much of the land is administered by pubilic agencies such as the U.S. Forest Service, Bureau of Land Management, and LoS Angeles Department of Water and Power. Major land uses are livestock grazing, timber production, watershed, and outdoor recreation. The only community of any size within the KGRA is Mamoth Lakes Village, with a permanent population of about 3,000 that can rise to 20,000 or more during the ski season.

In general, the ambient noise environment appears to be quiet, typical of rural and open space areas. Natural noise sources include animals, wind, and occasional sumer thunderstorms (Woodward-Clyde Consultants 1977). The most significant man-made noise is associated with transportation corridors (U.S. Forest Service 1978). U. S. Route 395, the main Reno-Los Angeles highway, traverses Mono-Long Valley KGRA on a north-south alignment. It is heavily traveled during the winter sports season and in the sumer as well. State Route 120 carries traffic over the Sierra Nevada to and from Yosemite National 
Park and central California in the summer. A major transcontinental airline route crosses the region, while Mammoth Airport is used by both general aviation and small commercial carriers operating turbo-prop and jet aircraft. Machinery used in logging; mining, and ranching operations is sometimes audible in various localities. Recreational activities are sometimes accompanied by vehicular noise sources such a motorcyles, snowmobiles, and motorboats (U. S. Forest Service 1978). No industrial noise sources of any significance currently exist in the region.

Quantitative data on ambient noise conditions are very limited. The U.S. Geological Survey (1976) Environmental Analysis for an exploratory geothermal drilling project stated that ambient SPL in the lease area (approximately $6.4 \mathrm{~km}$ or $4 \mathrm{mi}$. northeast of the Marmoth Airport) were well below $50 \mathrm{~dB}(\mathrm{~A})$ in the absence of human activity. Measurements carried out at the same site just prior to the drilling operation yielded SPL of approximately $30 \mathrm{~dB}(\mathrm{~A})$ (FraserSmith 1977). Noise from aircraft approaching or leaving the Mamoth Airport was audible during the time that these measurements were taken. The highest instantaneous SPL recorded was $48 \mathrm{~dB}(\mathrm{~A})$ when a jet aircraft was in the area.

The California Department of Transportation has measured highway noise at several points along U.S. Route 395: Mammoth Airport, June Lake Junction, and Crestview. Traffic noise at various distances from a roadway can also be estimated by a graphic method which relates the number of vehicles per hour past a given point, percent of trucks, and traffic speed.

\section{Noise Receptor Sites}

Residences, schools, and health care facilities are particularly sensitive to noise intrusion and require special consideration in the planning of any industrial project which may be a significant source of noise. In Mono-Long Valley KGRA such receptors are concentrated at Mammoth Lakes Village and Lee Vining. Some other residences are scattered along U.S. Route 395 and on short side roads. In addition, a few isolated ranch houses are located near the Owens River. Recreation sites such as camp grounds and ski areas may be considered sensitive to geothermal noise. Designated wilderness areas should also be protected from noise intrusion. Finally, certain kinds of wildlife habitat such as sage grouse strutting grounds, raptor nest sites, waterfowl breeding areas, and game migration routes may fall into the sensitive noise receptor category.

The locations of most receptor sites in the KGRA are well-known and could be readily plotted on a map for convenient reference. However, it is possible that not all of the sensitive wildlife areas have been discovered and accurately located. In any case, no maps of noise receptors are available for the region.

Noise Propagation Models

Once noise sources have been identified and characterized and the location of sensitive receptors has been determined, an adequate noise propagation model will allow accurate prediction of SPL and frequency spectra at the receptor. Methods which are currently in use at The Geysers-Cal istoga KGRA in northern California seem to give reasonable results and can be adapted for use in the Mono-Long Valley area (Bush 1977, Pacific Gas and Electric Company 
1977, Fimmons and Whitescarver 1978). These field-tested noise propagation models indicate that an attentuation of at least $40 \mathrm{~dB}$ can be expected over a distance of $0.8 \mathrm{~km}(0.5 \mathrm{mi})$. This suggests that the loudest geothermal noise sources expected would be attenuated to about $55 \mathrm{~dB}(\mathrm{~A})$ at that distance. However, winter meteorological conditions in the Mono-Long Valley KGRA may require special consideration in the prediction of SPL at receptors. Shallow temperature inversions are comon during clear cold weather and sound could propagate longer distances than expected by refraction from these inversion layers (Peterson and Palmer 1977).

\section{Noise Criteria and Standards}

Community Noise

The so-called "Levels Document" published by the Environmental Protection Agency (1974) identifies environmental noise levels which, according to the best available scientific studies, appear to protect against community annoyance and activity interference. The criterion proposed in this document for residential areas, schools, and hospitals is an outdoor day-night equivalent sound level $\left(L_{d n}\right)^{*}$ of $55 \mathrm{~dB}$. This level provides useful guidance in judging the acceptability of noise intrusion, but in no way represents a Federal standard. The document does not consider the economic or technological feasibility of attaining such a level, nor does it consider local needs and attitudes. For example, this criterion may not be adequate in the MonoLong Valley area because of the low existing ambient noise levels. Geothermal industry operations may be audible at considerable distances and could lead to annoyance even at noise levels well below an $L_{d n}$ of $55 \mathrm{~dB}$.

Regulatory authority over comunity noise levels is delegated to local government jurisdiction by the State of California. A Noise Element must be included in the General Plan for each county. This document provides the basis for local programs to control environmental noise. It does not set standards, but rather describes existing noise conditions, develops criteria for noisecompatible land-use planning, and outlines techniques for achieving an acceptable noise environment. Mono County has not yet adopted a General Plan Noise Element, and there is no county noise ordinance.

The only published environmental noise criterion which would specifically apply to geothermal industry operations is that contained in the U.S. Geological Survey (1975) Geothermal Resources Operational Order No. 4. This document states that geothermal-related activities on Federal leases shal1 not exceed a noise level of $65 \mathrm{~dB}(\mathrm{~A})$ at the lease boundary or at $0.8 \mathrm{~km}(0.5 \mathrm{mi})$ from the source, whichever is greatest. No such criteria exist for geothermal operations on land leased from the State or from private owners.

* $L_{\text {dn }}$, day-night equivalent sound level, is the 24-hour A-weighted sound levei that contains the same total acoustic energy as the actual time-varying sound, with a $10 \mathrm{~dB}$ penalty applied to the levels from 10:00 p.m. to 7:00 a.m. 
Domestic Livestock and Wildlife

There are no generally accepted criteria which would apply to the prevention of adverse noise effects on animals. It must be assumed, in the absence of definitive studies, that application of the criteria suggested for humans in the EPA "Levels Document" will serve to protect animals against behavioral disruption and physiological damage from noise (U.S. Environmental Protection Agency 1974).

\section{RECOMMENDATIONS}

In general, adequate information is available to assess the potential for environmental noise impacts from geothermal resource development in the Mono-Long Valley KGRA. Although it does not appear that noise will be a significant problem, certain additional data would be very useful in future impact analyses.

\section{Source Term Measurements}

Sound pressure levels and frequency spectra are not available for some geothermal operations that may be important noise sources. These activities include (1) test flowing of full-scale fluid production from individual wells and (2) the operation of flash units at the wellhead or near the power plant to separate steam from residual hot water. Noise emissions data for these processes will probably become available in the near future as a result of field measurements at geothermal facilities in the Imperial Valley and at Roosevelt Hot Springs in Utah.

Ambient Noise Measurements

Existing environmental noise conditions should be documented prior to development at all sites where commercial use of geothermal resources is proposed. Measurements should be made in general conformance with the guidelines of the Geothermal Environmental Advisory Panel (1976). Sampling would normally be carried out at key locations within the geothermal leasehold unit, at its boundaries, and at nearby receptor sites; a map of these monitoring locations would be prepared. It is desirable to measure both A-weighted and C-weighted $S P L$. The results should be expressed as equivalent SPL $\left(L_{e q}\right)^{*}$, as dayl night eguivalent SPL $\left(L_{d n}\right)$, and as the statistical descriptors $L_{10}, L_{50}$,

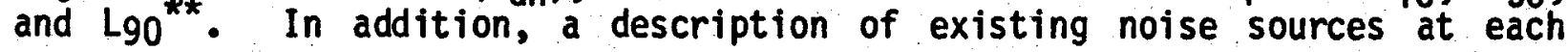
monitoring location should be provided.

* Leq, equivalent sound level, is the constant A-weighted sound level that, for a given period, contains the same total acoustic energy as the actual time-varying sound.

** $L_{10}, L_{50}, L_{90}$ are the A-weighted sound levels that are equaled or exceeded 10,50 , and 90 percent of the time, respectively. 


\section{Noise Receptor Sites}

A map should be prepared that shows the location of sensitive noise receptors in the vicinity of a proposed geothermal dvelopment area. These receptor sites should include:

1. Residences

2. Hospitals

3. Schools

4. Recreation Sites

5. Wilderness Areas

6. Sensitive Wildlife Areas

The mapping effort should be extended up to two miles beyond the sites of proposed geothermal development activities.

\section{Noise Criteria and Standards}

Notse emissions are expected to be of moderate intensity during the development and operation of geothermal facilities in Mono-Long Valley KGRA. There should be little difficulty in meeting the standard of $65 \mathrm{~dB}(A)$ at $0.8 \mathrm{~km}(0.5$ mi) from the source set by the U.S. Geological Survey (1975). However, because of the low ambient noise levels and occasional winter temperature inversions, geothermal noise might sometimes be audible at distances of $3.2-4.8 \mathrm{~km}(2-3 \mathrm{mi})$. If sensitive receptors or land-uses exist within 3.2-4.8 $\mathrm{km}$ of a project site, it would be well to consider the need for a noise standard lower than $65 \mathrm{~dB}(A)$ or even below an $L_{\mathrm{dn}}$ of 55 to avoid annoyance and activity interference. In most cases, a careful analysis of the expected source levels and available noise control strategies should indicate economically feasible ways of avoiding significant tmpacts. 


\section{REFERENCES CITED}

Atlantis Scientific. 1975. Environmental Impact Report, Castle Rock Springs Geothermal Steam Area, Lake County, California. Prepared for Burmah 0 il and Gas Co.

Atlantis Scientific. 1976. Environmental Impact Report, Ford Flat Geothermal Steam Area, Lake County, California. Prepared for the County of Lake Planning Department.

Bush, R. C. 1976. An overview of PG\&E's audible noise measurement program at The Geysers. Geothermal Environmental Seminar - 176, October 27-29, 1976, Lake County, California.

Bush, R. C. 1977. Plant and equipment noise treatment. Pacific Coast Electrical Association Engineering and Operating Conference, March 1718, 1977, Los Angeles, California.

ECOVIEW Environmental Consultants. 1977. A draft Environmental Impact Report for Union 017 Company Unit *17 development area, Lake County, California. Prepared for the County of Lake Planning Department.

Environmental Impact Planning Corporation. 1977. Long Ridge geothermal leasehold - draft Environmental Impact Report. Prepared for the County of Lake Planning Department.

Fraser-Smith, E. B. 1977. The effect of drilling a geothermal well on the behavior and reproduction of sage grouse. Prepared for Republic Geothermal, Inc., by Enviros, Los Altos, California.

Geothermal Environmental Advisory Panel. 1976. Guidelines for acquiring environmental baseline data on federal geothermal leases. Office of the Area Geothermal Supervisor, U. S. Geological Survey, Menlo Park, California.

Illingworth, R. R. 1976. Factors contributing to annoyance by geothermal steam well venting at The Geysers. Geothermal Environmental Seminar - '76, October 27-29, 1976, Lake County, California.

Leitner, P. 1978. An environmental overview of geothermal development: The Geysers-Calistoga KGRA. Volume 3. Noise. UCRL-52496. Lawrence Livermore Laboratory, University of California, Livermore, California 94550.

Pacific Gas \& Electric Company. 1977. Environmental data statement, Geysers Unit 16. San Francisco, California. August 19, 1977.

Peterson, K. R., and T. Y. Palmer. 1977. Climatology and air quality of Long Valley geothermal resource area. Lawrence Livermore Laboratory Report UCID-17459, Rev. 1. National Technical Information Service, Springfield, Virginia. 
Soclotechnical Systems, Inc. 1977. Draft Environmental Impact Report, Northern California Power Agency/Resource Funding Limited, Cobb Valley Geothermal Project. Prepared for County of Lake Planning Department.

Timmons, A. S. and 0. D. Whitescarver. 1978. Geysers simplified noise model, Unit 17 geothermal development area. Union 011 Compeny of California, Santa Rosa, California.

U. S. Environmental Protection Agency. 1971a. Noise from construction equipment and operations, building equipment, and home appliances. PB 206 717. Prepared by Bolt, Beranek, and Newman.

U. S. Environmental Protection Agency. 1971b. Transportation noise and noise from equipment powered by internal combustion engines. NTID 300.13.

U. S. Environmental Protection Agency. 1974. Information on the levels of environmental noise requisite to protect public health and welfare with an adequate margin of safety. Document No. 550/9-74-004.

U. S. Forest Service. 1978. Draft Environmental Statement, Land Management Plan, Mamoth-Mono Planning Unit.

U. S. Geological Survey. 1975. Geothermal Resources Operational Order No. 4. General environmental protection requirements. Office of the Area Geothermal Supervisor, U. S. Geological Survey, Menlo Park, California.

U. S. Geological Survey. 1976. Final Environmental Analysis \#23, prepared for three (3) proposed deep exploration holes on Lease CA-963, Republic Geothermal, Inc., Long Valley, California. Office of the Area Geothermal Supervisor, U.S. Geological Survey, Menlo Park, California.

Whitescarver, 0. D. 1978. Mufflers to abate noise and particulate emissions from geothermal development operations. Proceedings, Geothermal Seminar '78, May 9-11, 1978, Lake County, California.

Woodward-Clyde Consultants. 1977. Exploratory geothermal well drilling operations at Long Valley, California. Environmental data statement prepared for Union $0 i 1$ Company of California. Woodward-Clyde Consultants, San Francisco, California. 


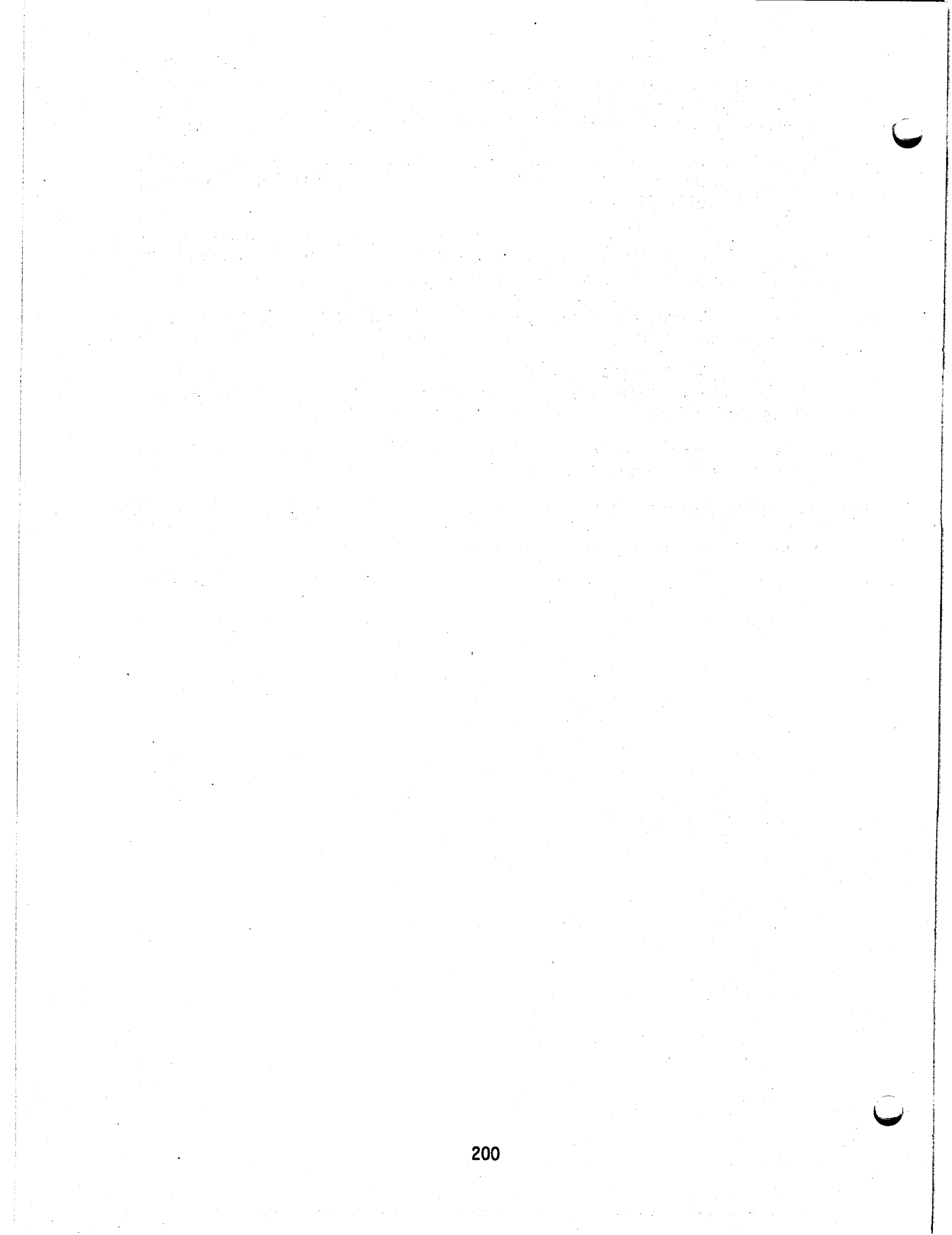




\title{
Chapter 8
}

\section{SOCIOECONOMICS OVERVIEW}

\author{
William J. Moffitt and Linda L. Stocks \\ Laboratory of Nuclear Medicine and Radiation Biology \\ University of California, Los Angeles
}


1. INTRODUCTION ..................... 204

2. MONO-LONG VALLEY SOCIAL AND ECONOMIC OVERVIEW . ... 206

2.1 Population ..................... 206

2.2 Age, Education, and Race .......... 207

2.3 Political Affiliation .............. 208

2.4 Length of Residence ............ 209

2.5 Income and Employment ............ 209

2.6 Economic Base .............. 212

2.7 Retail Trade ................ 213

2.8 Crops and Livestock ............. 214

2.9 Timber .................. 214

2.10 Mining ...................... 214

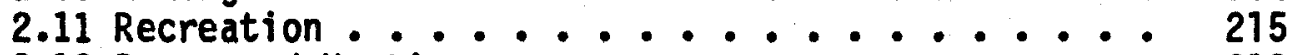

2.12 Power and Heating ........... 219

2.13 County finance .............. 221

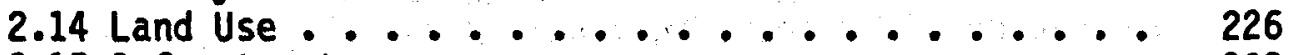

2.15 Infrastructure ............... 232

3. GEOTHERMAL DEVELOPMENT AND POTENTIAL IMPACTS .... 236

3.1 Scenario ................. 236

3.2 Issues and Effects .............. 236

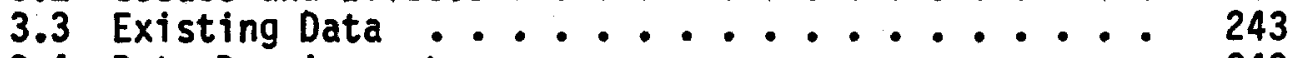

3.4 Data Requirements ............. 249

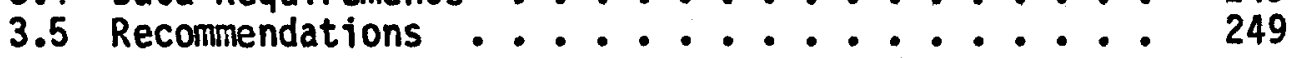

ACKNOWLEDGMENTS ..................... 251

REFERENCES CITED .................. 252 


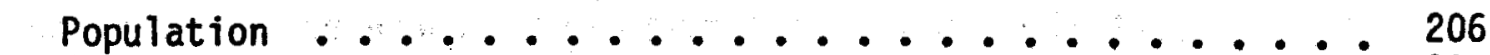

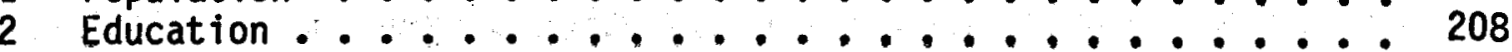

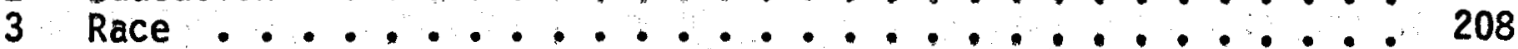

4 Count of Families by Family Income ............ 209

5 Count of Families and Unrelated Individuals

by Family Status and Type of Income ......... 210

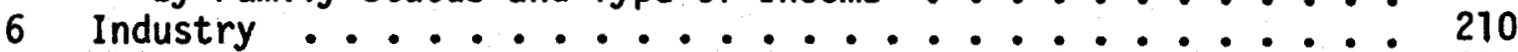

7 Number of Employees .................... 211

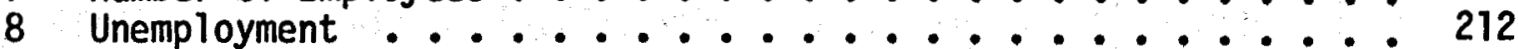

9 Taxable Sales by Type of Business ............ 213

10 Crop and Livestock Income ............... 214

11 Summer Recreation in the Mammoth Area .......... 215

12 Monthly Distribution of Mammoth Visitor

Expenditures with Percent of Yearly

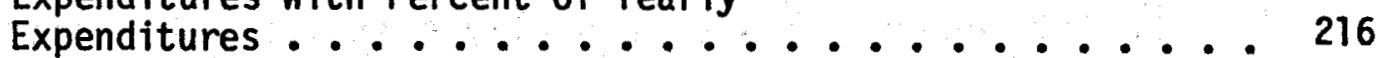

13 Forecasted Population Growth by County for

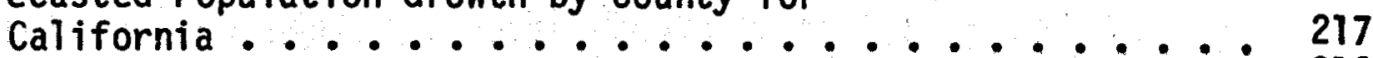

14 Electrical Generation and Capacity ........... 219

15 Electrical Energy Sales .............. 220

16 Mammoth Village Area Peak Power Demands ........ 220

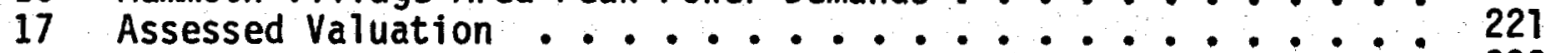

18 Sumary of County Revenues ............ 222

19 Summary of County Expenditures $\ldots$

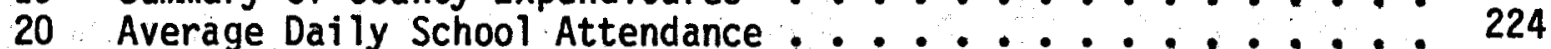

21 Mono County Schools General Fund Income . . . . . . ... 225

22 Mono County Schools General Fund Expenditures ....... 225

23 Residential Construction in Mono County .......... 227

24 Existing Residential Units .............. 227

25 KGRA Land Ownership .................. 228

26 County Land Ownership ................ 228

27 Public Agencies Invol ved in the Geothermal $\ldots \ldots . . \ldots 234$

\section{LIST OF FIGURES}

1 Mono County Census Divisions (Map) .......... 205

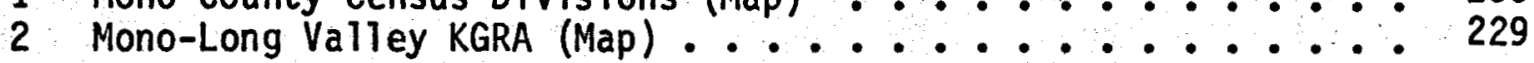




\section{INTRODUCTION}

It would be useful at the onset to set forth the purpose of this chapter. It is intended to be a constrained characterization of the social and economic nature of the Mono-Long Valley KGRA. An overview of existing information has been compiled and geothermal-related issues and concerns have been identified. Finally, data gaps have been identified and recommendations made for satisfaction of these needs.

The Mono-Long Valley KGRA is primarily located in Mono County, a sparsely populated area situated on the eastern edge of California approximately 190 miles east of San Francisco and 260 miles north of Los Angeles. The KGRA also includes a very small uninhabited segment of Madera County which is not considered significant in a socioeconomic sense. Inyo County lies immediately to the south, the state of Nevada to the east and north, and Alpine, Tuolumne, Madera, and Fresno counties to the west. For socioeconomic purposes, the KGRA's area of 719 square miles essentially coincides with the southern census division of Mono County (Fig. 1). The county is 3,028 square miles in area as compared with its southern neighbor, Inyo County, with 10,091 square miles. Undoubtably some spillover effects of geothermal development in the KGRA would occur in Inyo County, and for that matter in other counties such as Los Angeles. These effects are not considered to be significant for this study, and consequently the focus is on Mono County and particularly the primary impact area of Mammoth Lakes. The area is served by Highway 395 which runs essentially north and south for the entire length of the county and is the access route from the Los Angeles area; by Highway 120, running from 395 over Tioga Pass in Yosemite National Park and forming the main access from the San Francisco area; by Highway 158 which leaves 395 and forms the June Lake Loop; and by Highway 203 which provides access from 395 to Mammoth Lakes.

The area includes high desert, forest, mountain, and alpine terrain and is dominated by the eastern Sierra Nevada escarpment which borders on the west. Most of the land (approximately 75\%) is owned by the federal government. Fifty-five percent of the KGRA is administered by the Forest Service. The portion along the Sierra Nevada has an abundance of streams, forests, and mountains, providing attractive terrain for skiing, hiking, fishing, hunting, and other outdoor related activities. It is also the location of numerous trailheads into the Hoover, Minarets, and John Muir Wilderness areas.

The Mono-Long Valley KGRA encompasses the communities of Mammoth Lakes, Lee Vining and June Lake. Mammoth Lakes is the largest community in Mono County and is virtually contiguous to the potential geothermal lease area. The town is unincorporated; in fact there are no incorporated towns in Mono County. Crowley Lake, a popular fishing location is also adjacent to the proposed lease area.

Long before the white man first came to the Mono-Long Valley area, the northern Paiute Indians made it their home. They settled in several small groups and were generally peaceful. Their combined population was less than 1,500 people (USDA, Forest Service 1978, p. 12). The first white men to arrive were the trappers looking for beaver to satisfy the demand for beaver-trimmed hats in the east. They arrived in the early 1800's and were soon followed 


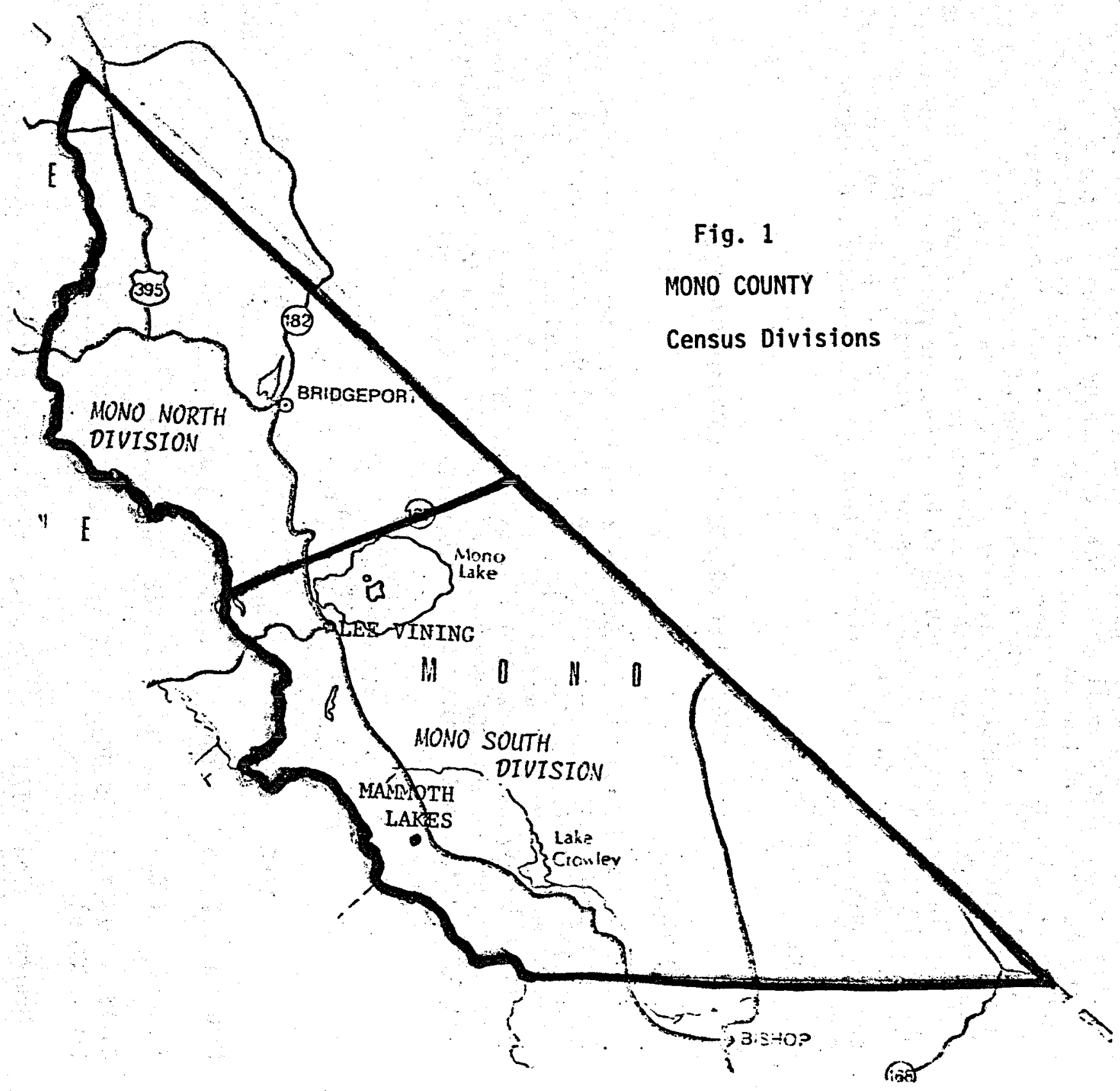


by traders looking for routes to the coast. In 1845, John Fremont led a party into the area for the purpose of exploring and mapping.

The early days of the gold rush were centered on the western slopes of the Sierras and it wasn't until about 1853 that Leroy Vining led the first group of prospectors down the eastern side and into what was then the eastern portion of Calaveras County. However, by the time the first census was taken in the area (1870) many of the miners had gone elsewhere and population data indicate only 430 residents (Smith 1976, p. 134). In 1877 several claims were filed in the Mammoth area which were bought by General Dodge who formed the Mammoth Mining Company. The ensuing rush brought the population of Mammoth to about 2,500 (Smith 1976, p. 136). However the bonanza never materialized and the mill shut down in 1880. Many other small towns sprang up during this period, only to die when the minerals gave out. The farmers and ranchers who came stayed on.

\section{MONO-LONG VALLEY SOCIAL AND ECONOMIC OVERVIEW}

\subsection{Population}

In terms of population, Mono County is a small (third smallest in California), sparsely populated, but rapidly growing area. The county's population grew from 2,213 to 4,016 , or $81 \%$, in the decade of the $1960^{\prime} \mathrm{s}$. As is indicated in Table 1, this growth rate was more than three times that of the state. During the first two years of the 1970's it expanded an additional 45\%, then slowed down to a more modest $28 \%$ between 1972 and 1977 . Mono County's population density in 1977 was estimated to be 2.5 persons per square mile.

TABLE 1

\section{POPULATION}

$\begin{array}{lrrrrrrr} & \underline{1960} & \underline{1970} & \underline{1972} & \underline{1977} & \begin{array}{c}\text { Proj. } \\ 1980\end{array} & \begin{array}{c}\text { Proj. } \\ 1985\end{array} & \begin{array}{r}\text { Proj. } \\ 2000\end{array} \\ \text { Mono Co. } & 2,213 & 4,016 & 5,839 & 7,475 & 8,700 & 10,300 & 14,200 \\ \text { Inyo Co. } 11,684 & 15,571 & 16,262 & 17,450 & 18,100 & 20,100 & 25,800 \\ \text { Calif. } 15,717 & 19,955 & 20,590 & 21,520 & 22,799 & 24,546 & 29,287 \\ \text { (in 1,000's) } & & & & & & \end{array}$

Source: 1960, 1970: U.S. Census. 1972, 1977: Calif. Co. Fact Books. 1980, 1985, 2000: Department of Finance, Population Projections for Calif. Counties

The last full census, 1970 , indicated some $64 \%(2,558)$ of the county's population was located in the southern district, or essentially the KGRA. The Mammoth Lakes Village area accounts for a large proportion of this population. Other population centers in the study area are the June Lake, Lee Vining, and Hilton Creek areas. For 1972 these communities accounted for 
approximately $42 \%$ of the population of the KGRA (study area). The remainder, $57 \%$, resided in the Manmoth Lakes area.

The 1972 resident population of the Mammoth Lakes Village area has been variously estimated to be approximately 2,000-2,200 (UCLA 1972a, p. 11, USDA, Forest Service 1978, pp 13-14). This contrasts with a peak 1972 summer population of 14,500 and a peak 1972 winter population of 16,000 (UCLA 1972a, p. f). The key factor influencing growth is demand for and development of ski facilities in the area. Continued development hinges on whether or not another major ski area is developed elsewhere for Southern California ski enthusiasts. Without this competitive development, it has been suggested that the peak winter population in the Village area will grow to 35,000 by 1985 . If an alternative site is developed, the same study forecasts a winter peak of some 19,000 (UCLA 1972a, p. f).

Significant resident population growth for the entire study area is a reflection of its economic base, namely recreation which is predominantly skioriented. During the past several years, economic recession, poor snow conditions, and restrictions on construction relating to water and waste disposal combined to limit growth. These conditions have moderated and no major alternative ski area for the Los Angeles market appears imminent. Consequently, it would seem that unless the county takes some action to 1 imit growth, population will continue to grow at a pace which, while relatively small in actual numbers of people, is rather significant in terms of impact. As may be seen from Table 1 , Mono County is expected to repeat its rapid growth in the 1970's. It is anticipated that the growth rate will fall off in the 1980 's, yet the projected rate of increase to the year 2000 exceeds that of neighboring Inyo County and is some two times that of the state as a whole. During the same period the rate of household formation is projected to exceed that of population growth due to the decreasing number of persons per household (Calif. Dept. of Finance $1977 \mathrm{c}$ ). As a result, there will be an increasing demand for energy.

\subsection{Age, Education, and Race}

The southern portion of Mono County has attracted a relatively young mix of people. At the time of the 1970 census, approximately $51 \%$ of the population was under 30 years of age. Comparable figures are $49 \%$ for Mono County as a whole, $46 \%$ for Inyo County, and $43 \%$ for the State of California. The 1972 special census for Mono County indicates an increase for this age group to $54 \%$. This represents a decrease in the median age for the county from 30 in 1970 to 27 in 1972. Thirteen percent of the population in 1972 was 55 or older. This was less than the ratio for Mono County in its entirety and for Inyo County. During the latter 1970 's the ratio has been shifting with the result that the estimated median age for Mono County in 1975 increased to 32 . This median is expected to grow to 38 in 1990 (Calif. Dept. of Finance 1977b).

Seventy-two percent of the 1970 study area population 25 years of age and older were reported as having completed high school (Table 2). Nine percent 
of the same population has completed four years of college (U.S. Dept. of Commerce 1970). This percentage of high school graduates exceeds that of the state, while the percentage of college graduates is somewhat less than that for the state as a whole.

TABLE 2

$$
\begin{gathered}
\text { (Persons } \begin{array}{c}
\text { EDUCATION (1970) } \\
25 \text { years of age or older) } \\
\text { Completed } \\
\text { High School }
\end{array} \quad \begin{array}{c}
\text { Completed } 4 \text { or more } \\
\text { Years of College }
\end{array}
\end{gathered}
$$

So. Div. Mono Co.

Mono County

Inyo County

California
$72 \%$

$71 \%$

$62 \%$

$63 \%$

Source: 1970 Census.

\begin{tabular}{|c|c|c|c|c|c|}
\hline$\zeta$ & White ${ }^{a}$ & Black & $\begin{array}{l}\text { Spanish } \\
\text { American }\end{array}$ & Indian & Other \\
\hline $\begin{array}{l}\text { So. Div. Mono Co. } \\
\text { Mono County } \\
\text { Inyo County } \\
\text { Cal ifornia }\end{array}$ & $\begin{array}{l}97 \% \\
94 \% \\
84 \% \\
89 \%\end{array}$ & $\begin{array}{l}<1 \% \\
<1 \% \\
<1 \% \\
7 \%\end{array}$ & $\begin{array}{l}2 \% \\
1 \% \\
7 \% \\
\text { (b) }\end{array}$ & $\begin{array}{r}5 \% \\
8 \% \\
<1 \%\end{array}$ & $\begin{array}{r}1 \% \\
<1 \% \\
1 \% \\
3 \%\end{array}$ \\
\hline
\end{tabular}

The study area is predominately Caucasian (Table 3). In 1970 only some $3 \%$ of its population was of a minority ethnicity in contrast with $16 \%$ for Inyo County and 11\% for California (U.S. Dept. of Commerce 1970, Table 17).

TABLE 3

RACE (1970)

aExcluding Spanish American and Indian for Counties

bspanish American for California is included in White

Source: 1970 Census.

\subsection{Political Affiliation}

Voter registration for Mono County reveals a shift from a significant Republican margin in 1968 and 1970 to a Democratic edge in 1976. This edge of $47 \%$ Democratic to $45 \%$ Republican was still, however, less than that of California's 57\% Democratic to $36 \%$ Republican. Independent and Decline to State registrants increased in number; however, they constituted only $7 \%$ of the total (County Supervisors Assn. 1977-78, pp. 54-57). 


\subsection{Length of Residence}

Reflecting its rapid growth rate and its recreation base, the area has a significant number of relatively new residents. This may be a factor in the lack of homogeneity in attitudes and values. The 1972 special census of Mono County determined that $32 \%$ of the Mammoth area residents had a length of residence of one year or less (Calif. Dept. of Finance 1972). In 1970, the comparable percentages for one year or less family residence were again $32 \%$ for Mammoth, $25 \%$ for Mono County, and $30 \%$ for the state (U.S. Dept. of Commerce 1970, Table 50).

\subsection{Income and Employment}

Available data indicate a surprising number of residents with a relatively low income level. This would appear to be consistent with the employment conditions as assessed below. Mono County South reported 19\% of its families as earning less than $\$ 5,000$ in 1970 . This compares with $17 \%$ for Inyo County and California, and is the same as that for Mono County in its entirety. Some $51 \%$ of Mono County South's families earned $\$ 10,000$ or more as compared with $50 \%$ for Mono County, 54\% for Inyo County, and $55 \%$ for California (see Table 4).

TABLE 4

COUNT OF FAMILIES BY FAMILY INCOME. (1970)

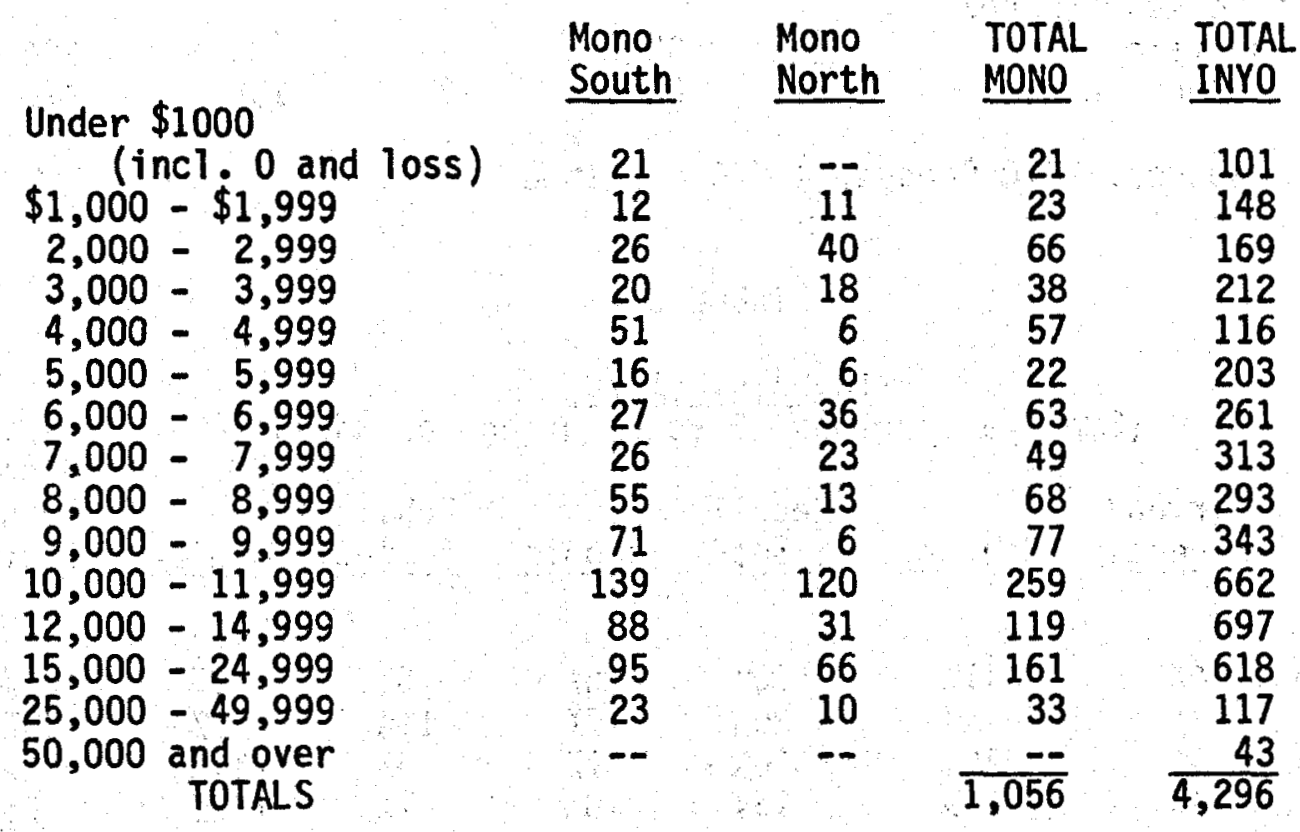

Source: 1970 Census, 4th Count Tape. 
On the other hand, during 1970, only $8 \%$ of Mono County South's families were receiving Social Security or other forms of public assistance as compared with 17\% for Inyo and $12 \%$ for Mono Counties (see Table 5). Similar data for unrelated individuals indicates $20 \%, 36 \%$ and $22 \%$ for the aforementioned areas respectively.

\section{TABLE 5}

COUNT OF FAMILIES AND UNRELATED INDIVIDUALS 14 YEARS AND OVER BY FAMILY STATUS AND TYPE OF INCOME (1970 Census)

\begin{tabular}{|c|c|c|c|c|}
\hline & $\begin{array}{l}\text { Mono } \\
\text { South }\end{array}$ & $\begin{array}{l}\text { Mono } \\
\text { North }\end{array}$ & $\begin{array}{l}\text { TOTAL } \\
\text { MONO } \\
\end{array}$ & $\begin{array}{l}\text { TOTAL } \\
\text { INYO } \\
\end{array}$ \\
\hline \multicolumn{5}{|l|}{ Family } \\
\hline $\begin{array}{l}\text { Wage and Salary } \\
\text { Non-farm self employed } \\
\text { Farm self employed } \\
\text { Social Security/ }\end{array}$ & $\begin{array}{l}565 \\
164 \\
10\end{array}$ & $\begin{array}{r}318 \\
107 \\
34\end{array}$ & $\begin{array}{r}883 \\
271 \\
44\end{array}$ & $\begin{array}{r}3487 \\
655 \\
60\end{array}$ \\
\hline Railroad Retirement & 46 & 78 & 124 & 896 \\
\hline $\begin{array}{l}\text { Public Assistance/ } \\
\text { Welfare } \\
\text { All other income }\end{array}$ & $\begin{array}{r}28 \\
137\end{array}$ & $\begin{array}{r}52 \\
143\end{array}$ & $\begin{array}{r}80 \\
280\end{array}$ & $\begin{array}{r}265 \\
1538\end{array}$ \\
\hline \multicolumn{5}{|l|}{ Unrelated Individuals } \\
\hline Wage and Salary & 220 & 109 & 329 & 779 \\
\hline $\begin{array}{l}\text { Non-farm self employed } \\
\text { Farm self employed } \\
\text { Social Security/ }\end{array}$ & $\begin{array}{l}55 \\
--\end{array}$ & $=$ & $\begin{array}{l}55 \\
--\end{array}$ & $\begin{array}{r}61 \\
7\end{array}$ \\
\hline $\begin{array}{l}\text { Railroad Retirement } \\
\text { Public Assistance/ }\end{array}$ & 53 & 65 & 118 & 529 \\
\hline $\begin{array}{l}\text { Welfare } \\
\text { All other income }\end{array}$ & $\begin{array}{l}35 \\
86\end{array}$ & $\overline{73}$ & $\begin{array}{r}35 \\
159\end{array}$ & $\begin{array}{l}224 \\
470\end{array}$ \\
\hline
\end{tabular}

Source: 1970 Census, 4th Count Tape.

TABLE 6

(Employed persons 16 years of age or more)

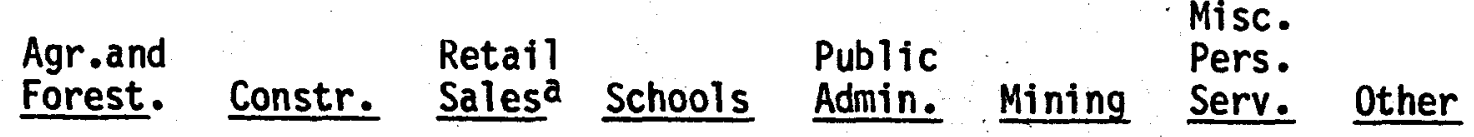

So. Div.

$\begin{array}{ccccrrrrr}\text { Mono Co. } & 4 \% & 11 \% & 20 \% & 6 \% & 8 \% & 2 \% & 31 \% & 18 \% \\ \text { Mono Co. } & 7 \% & 15 \% & 20 \% & 7 \% & 11 \% & 1 \% & 23 \% & 16 \% \\ \text { Inyo Co. } & 4 \% & 10 \% & 20 \% & 7 \% & 5 \% & 11 \% & 11 \% & 32 \% \\ \text { California } & 3 \% & 5 \% & 16 \% & 8 \% & 7 \% & <1 / 2 \% & 5 \% & 56 \%\end{array}$

afood, bakery, dairy, general merchandise, motor vehicle, and other retail trade.

Source: 1970 Census, 4th Count Tape. 


\section{TABLE 7}

EMPLOYMENT IN INYO AND MONO COUNTIES

$$
\text { Number of Employees - } 1976
$$

Construction $\begin{array}{lllllllllllll}\text { Inyo } & 89 & 76 & 71 & 101 & 99 & 111 & 124 & 130 & 131 & 146 & 141 & 132\end{array}$ Mono Manufacturing Inyo Mono

no separate data available ation and Public Utilities $\begin{array}{lllllllllllll}\text { Inyo } & 373 & 382 & 377 & 394 & 391 & 381 & 389 & 385 & 400 & 390 & 400 & 393\end{array}$ Mono

Source: California Employment Development Department, California Employment and Payrolls, 1976 (averages and totals have been modified).

$1976 \quad \begin{array}{ccc}1976 & 1975 \\ \text { Annual } & 1975 \quad \text { Annual }\end{array}$ Average Wages Average Wages Empl'mt. $(\$ 1000)$ Empl 'mt. $(\$ 1000)$

\begin{tabular}{rrrr}
113 & $\$ 1187$ & 99 & $\$ 1024$ \\
244 & 2708 & 199 & 2159 \\
\hline 77 & 619 & 101 & 925 \\
& & & \\
388 & 5325 & 394 & 4805 \\
52 & 678 & 55 & 666 \\
1351 & 7913 & 1416 & 7772 \\
730 & 3176 & 658 & 2651 \\
160 & 1252 & 148 & 1117 \\
118 & 703 & 109 & 571 \\
853 & 4726 & 873 & 4398 \\
824 & 5153 & 955 & 5596 \\
275 & 3319 & 280 & 3247 \\
& & & \\
349 & 6371 & 353 & 6209 \\
33 & 769 & 38 & 740 \\
1332 & 11810 & 1249 & 10761 \\
484 & 5121 & 455 & 4569 \\
4898 & 42522 & 4913 & 40258 \\
2485 & 18398 & 2469 & 16952
\end{tabular}


The four most significant employment sectors for southern Mono County are miscellaneous personal services (including barbers, hairdressers, housekeepers for motels, etc.), retail sales (food, bakery, dairy, general merchandise, motor vehicle, and other retail trade), local government, and construction (Table 6). Data for 1976 show little change from 1970. Retail sales and construction appear as more significant employers of people in the study area than for the state as a whole.

Employment in the service sector during 1976 ranged from a high of 1400-1500 in January-February to a low of some 500 in November and December (1976 was a late snow year) (Table 7). Perhaps the impacts of recreation, tourism, and weather on employment are best reflected by a study of the 1971-1972 winter and summer seasons employment in the Mammoth area. While total employment was approximately equal for each season, summer service and retail sales employment was down 43\% over winter (Monoplan Associates 1975, p. 33). The balancing factor was employment in the private and public construction and maintenance sectors. While total employment for the seasons appears to be constant, the different skills required, seasonality and shortness of the seasons, and the vagaries of weather make for a dynamic employment system. This system is characterized by a significant percentage of transitory, seasonal workers requiring temporary housing. Average annual unemployment for Mono and Inyo Counties combined is greater than that of the state (Table 8), which is traditionally higher than the nation. For the last three years unemployment has exceeded $10 \%$ with a spread of approximately two points between state and county figures (Ripley 1978).

TABLE 8

UNEMPLOYMENT

$\begin{array}{lrrrr} & 1974 & 1975 & 1976 & 1977 \\ \text { Mono-Inyo Counties } & 8.7 \% & 12.4 \% & 11.4 \% & 10.3 \% \\ \text { California } & 8.6 \% & 9.8 \% & 9.2 \% & 8.2 \%\end{array}$

Source: California Employment Development Department (interview)

\subsection{Economic Base}

The study area is fundamentally dependent upon the single and sometimes unpredictable base of recreation/tourism. This underpinning of the economy is highly seasonal and reflective of meteorological vagaries on one hand and the general business cycle on the other. Since the recreational customer of our study area is usually from Los Angeles and vicinity, there is a significant dependence upon economic conditions affecting leisure spending by Los Angeles residents. As is indicated by Tables 6 and 7 , other contributors to the area's economy include agriculture, construction, timber, mineral, and government. 


\subsection{Retail Trade}

Again, the nature of Mono County's economic dependence on recreation and tourism is illustrated by its taxable sales (Table 9). In 1977, eating and drinking places accounted for $23 \%$ of all taxable sales. Another $19 \%$ was made by automobile service stations (Calif. State Board of Equilization 1977). Both categories show substantial percentage increases over prior years.

TABLE 9.

\section{TAXABLE SALES BY TYPE OF BUSINESS - MONO COUNTY}

Type of Business

Retail Stores

Apparel Stores

Gen. Merchandise Stores

Drug Stores

Food Stores

Package Liquor Stores

Eating and Drinking Places

Home Furn. and Appliances

Building Mat. and Farm Impl. Auto Dealers

Service Stations

Other Retail Stores

Retail Stores Total

All Other Outlets

Totals All Outlets
Taxable Transactions

in $\$ 1000$ 's

\begin{tabular}{rrrr}
1965 & 1970 & $\frac{1976}{2}$ & $\frac{1977}{}$ \\
\hline$a$ & $a$ & 234 & 233 \\
393 & 327 & 837 & 926 \\
- & $a$ & $a$ & $a$ \\
364 & 973 & 2,465 & 2,387 \\
159 & 385 & 1,040 & 938 \\
1,627 & 2,575 & 6,639 & 7,038 \\
$a$ & $a$ & 559 & 640 \\
89 & $a$ & 1,621 & 1,524 \\
- & $a$ & $a$ & $a$ \\
387 & 568 & 5,460 & 5,730 \\
$a 485$ & $a 1,879$ & $a 3,475$ & $a 4,333$
\end{tabular}

asales omitted to avoid disclosure of confidential information. "Other Retail Sales" include these figures.

Source: 1965: State Board of Equilization, Trade Outlets and Taxable Retail Sales in Calif. During 1965. 6th Annual Report, p. 13.

1970: Ibid., 10th Annual Report, p. 14.

1976: State Board of Equilization, Taxable Sales in Calif. (Sales and Use Tax During 1976), 16th Annual Report, p. 14 .

1977: Ibid. 17th Annual Report, 1st quarter, p. 12; 2nd quarter, p. $16 ; 3$ rd quarter, p. $12 ; 4$ th quarter, p. 16.

A large percentage of these sales are made in the Mammoth Lakes area. The Forest Service indicates that for 1973-1974 this share was 53\% (USDA Forest Service 1978, p. 20). This percentage is expected to increase due to the nore rapid development in the Mammoth Lakes area. 


\subsection{Crops and Livestock}

Agriculture and livestock production, while rather minor in terms of actual dollars due to the arid nature of the area, is one of the major non-recreation based income sources for Mono County. In 1974, crop and livestock income was at the $\$ 2.3$ million level (Table 10). During that year, $65 \%$ of the income came from field crops, $32 \%$ from livestock, and $3 \%$ from other products (Calif. Dept. of Finance 1977a, p. 90). In contrast, livestock and field crop percentage income for the lower elevation adjoining county of Inyo was essentialily reversed.

Livestock grazing in or near the study area is a commonly visible activity typically involving some three to four thousand sheep and a like number of cattie seasonally brought in from other areas of California and from Nevada.

TABLE 10

$$
\frac{\text { CROP AND LIVESTOCK INCOME (1974) }}{(\text { in } \$ 1,000)}
$$

\begin{tabular}{lrrrrr} 
& $\begin{array}{c}\text { Livestock } \\
\text { \& Livestock }\end{array}$ & $\begin{array}{r}\text { Field } \\
\text { Crops }\end{array}$ & Other & Total \\
\cline { 2 - 2 } Products & 733 & & 1,507 & 69 & 2,309 \\
Mono Co. & 2,136 & & 1,251 & 117 & 3,504 \\
Inyo Co. & $2,786,125$ & & $2,411,906$ & $3,436,094$ & $8,634,125$
\end{tabular}

Source: California Department of Finance. California Statistical Abstracts, 1977, p. 90

\subsection{Timber}

Timber production, particularly on Forest Service land, is another small but significant prop to the county's economy. Forest Service income from this activity is remitted by the federal government to the state and thence to the county. The Forest Service estimates that the average annual timber harvest within their Mammoth-Mono Planning Unit, roughly comparable in terms of timber area to the KGRA, for the last 10 years was 10 million board feet (USDA Forest Service 1978, P. 37). A portion of this production occurs within and adjacent to the proposed lease area. The same source estimated that in 1977, one could add $21 / 2$ million board feet from the gathering of down wood (fallen trees).

\subsection{Mining}

While Mammoth's early history is replete with tales of gold finds and a few abandoned mines are still to be seen in the surrounding mountains, mineral production in the study area today is very limited. Known resources include gold, silver, uranium, tungsten, zinc, pumice, clay, sand, and gravel. The 
only significant extractions currently are kaolinite (clay), sand, and gravel. The kaolinite production is in Little Antelope Valley, one of the prime sites for potential geothermal exploration.

\subsection{Recreation}

Recreation and tourism-related activities are key to the economic vitality of the study area. An analysis of the Mammoth area during 1971-1972 indicated that recreation-oriented retail sales and services accounted for $70 \%$ of the annual dollar volume. Resort lot sales and construction accounted for another $16 \%$, or a total of $86 \%$ directly related to recreation and tourism. The remaining $14 \%$ is related to governmental-public utility expenditures in the area (SWR 1975, p. 34).

In the early 1900's the City of Los Angeles, anticipating an ensuing water shortage, formulated a plan to bring water from the Owens Valley. The City of Los Angeles bought land and water rights and constructed the aqueduct system. Lake Crowley, located in the southeasterly corner of the study area, is the largest reservoir included in the Los Angeles aqueduct system. It is one of the state's most popular fishing areas.

During the late 1930 's ski rope tows were constructed on the slopes close to Highway 395. The crowds increased after World War II and there has continued to be a steady growth in skiing concentrated at Mammoth Mountain and June Mountain. Mammoth Mountain is currently the largest ski area, in volume of use, west of the Mississippi River. Over 1,307,200 skiers visited it during 1975 (USDA Forest Service 1977). There is also participation in cross-country skiing, tobogganing, snowshoeing, ice skating, sledding, and snowmobiling.

TABLE 11

\section{SUMMER RECREATION IN THE MAMMOTH AREA}

\begin{tabular}{lrr} 
& Use in 1970 & Use in est. 1985 \\
Activity & Visitor Days & Visitor Days \\
\hline Swimming & 14,200 & 23,600 \\
Fishing & 95,600 & 95,600 \\
Boating & 800 & 800 \\
Sightseeing & 22,600 & 34,600 \\
Nature walks & 7,500 & 11,200 \\
Camping & 814,400 & 814,400 \\
Hiking & 52,800 & 89,200 \\
Picnicking & 2,100 & 3,100 \\
Horseback riding & 2,800 & 4,100 \\
Auto driving & 240,700 & 356,500 \\
Auto &
\end{tabular}

Source: UCLA, Facing the Future, Five Alternatives for Mammoth Lakes; Final Report, 1972, p. 69. 
A similar growth has occurred in summer recreation. The area boasts numerous lakes accessibile by car and trail. Activities include camping, backpacking, fishing, swimming, boating, picnicking, sightseeing, hiking, horseback riding, visiting archaeological and historical sites, nature study, and photography (Table 11).

Most of the visits to the Mammoth-June Lake area occur in the summer. These summer visitors are spread out over a much larger area making the winter activities appear more crowded and overused. Winter recreation, however, has a greater impact on the local economy than the summer activities (Table 12). The average winter visitor spends about four times as much per day as does his summer counterpart (UCLA 1972a, p. 148).

TABLE 12

MONTHLY DISTRIBUTION OF MAMMOTH VISITOR EXPENDITURES WITH PERCENT OF YEARLY EXPENDITURES

$\begin{array}{lrlc}\text { January } & 9 \% & \text { July } & 13 \% \\ \text { February } & 10 \% & \text { August } & 12 \% \\ \text { March } & 10 \% & \text { September } & 6 \% \\ \text { Apri1 } & 9 \% & \text { October } & <1 \% * \\ \text { May } & 7 \% & \text { November } & 4 \% \\ \text { June } & 7 \% & \text { December } & 13 \%\end{array}$

*Source indicates $0 \%$ for 0ctober expenditures.

Source: UCLA, Facing the Future: Five Alternatives for Mammoth Lakes; Final Report, 1972, p. 70.

The wants and needs of the summer visitor are very different from those who visit during the winter. Lodges and inns do the majority of their business during the winter and then stand empty when the campers come during the summer. As has been mentioned, these fluctuations are reflected in employment. An example of this is the Mammoth Mountain ski facility which employs 900 persons during the winter and only 176 on a year-round basis (Mammoth Mountain Ski Area Personnel Office 1978). There is also a substantial variation in numbers of visitors from weekends to midweek. This is particularly important in the winter when the ratio is about three to one. In the summer the increase on weekends is only about 20\% (UCLA 1972a, p. 141).

Since the Mammoth area is so accessible to Southern California residents, growth in Southern California has a substantial impact on recreation facilities in the study area. A UCLA study published in 1972 indicated that the total population of California was expected to increase $30 \%$ from 1970 to 1985 with a corresponding increase in the participation rate for skiing of about 66\%. The total California ski market was also expected to increase by about 166\% during this time period (UCLA 1972a, p. 70). Population projections 
TABLE 13

FORECASTED POPULATION GROWTH BY COUNTY FOR CALIFORNIA TO 1985

County

Al ameda

Alpine

Amador

Butte

Calaveras

Colusa

Contra Costa

Del Norte

El Dorado

*Fresno

Glenn

Humboldt

*Imperial

*Inyo

*Kern

Kings

Lake

Lassen

*+Los Angeles

Madera

Marin

Mariposa

Mendocino

Merced

Modoc

*Mono

Monterey

Napa

Nevada

*+0range

Placer

Plumas

*+Riverside

Sacramento

San Benito

*+San Bernardino

*San Diego

San Francisco

San Joaquin

* San Luis Obispo

San Mateo

* Santa Barbara

Santa Clara

Santa Cruz

Shasta

Sierra

Siskiyou
July 1,1970

$1,063,800$

500

12,000

102,000

13,600

12,400

558,100

14,400

44,000

413,700

17,600

99,500

74,300

15,600

325,500

60,900

19,700

16,600

$7,006,600$

41,600

203,300

6,100

51,300

100,400

7,500

4,100

221,100

79,400

26,600

$1,419,200$

77,600

11,800

454,600

621,500

18,300

669,300

$1,245,100$

699,200

291,000

106,100

556,000

258,200

$1,070,000$

124,100

77,900

2,400

33,100
July 1, 1975

$1,091,400$

800

15,100

120,700

15,500

12,700

586,600

15,800

59,400

452,400

19,300

104,900

84,100

17,300

348,000

69,400

25,400

18,600

$6,947,200$

46,900

217,500

8,400

57,400

118,900

8,000

7,300

267,600

90,600

34,100

$1,713,400$

91,300

14,000

525,200

691,600

19,700

696,800

$1,594,100$

667,400

299,400

126,500

578,600

281,100

$1,180,300$

156,100

92,400

2,800

35,300
July 1, 1985

\% Increase

1970-1985

$1,140,600$

1,200

20,700

157,000

20,000

13,900

678,700

17,900

97,100

552,900

23,500

113,900

104,000

20,100

409,100

78,800

38,000

21,100

$7,373,700$

59,000

242,300

11,500

72,800

141,000

8,800

10,300

326,100

112,800

51,100

$2,175,700$

129,700

16,700

718,800

813,900

24,500

859,200

$2,041,300$

633,200

338,200

165,300

620,000

319,200

$1,379,500$

217,800

123,900

3,700

39,300
$7 \%$

140

73

54

47

12

22

24

121

34

34

14

40

29

26

29

93

27

5

42

19

89

42

40

17

151

47

42

92

54

67

42

58

31

34

28

64

$-5$

16

56

12

24

29

76

59

54 
TABLE 13 (cont.)

\begin{tabular}{|c|c|c|c|c|}
\hline County & July 1,1970 & July 1,1975 & July 1, 1985 & $\begin{array}{c}\text { \% Increase } \\
1970-1986 \\
\end{array}$ \\
\hline $\begin{array}{l}\text { Solano } \\
\text { Sonoma } \\
\text { Stanislaus } \\
\text { Sutter } \\
\text { Tehema } \\
\text { Trinity } \\
\text { Tulare } \\
\text { Tuolumne } \\
\text { *+Ventura } \\
\text { Yolo } \\
\text { Yuba }\end{array}$ & $\begin{array}{r}156,200 \\
205,200 \\
195,300 \\
42,000 \\
29,500 \\
7,700 \\
189,400 \\
22,400 \\
376,200 \\
92,200 \\
38,300\end{array}$ & $\begin{array}{r}188,000 \\
247,100 \\
224,600 \\
46,400 \\
32,000 \\
9,800 \\
208,600 \\
26,600 \\
440,700 \\
101,700 \\
45,200\end{array}$ & $\begin{array}{r}249,300 \\
316,300 \\
281,400 \\
56,900 \\
37,800 \\
12,700 \\
262,500 \\
37,200 \\
578,600 \\
120,900 \\
54,900\end{array}$ & $\begin{array}{l}60 \% \\
54 \\
44 \\
35 \\
28 \\
65 \\
39 \\
66 \\
54 \\
31 \\
43\end{array}$ \\
\hline California & $19,703,000$ & $21,198,100$ & $24,546,200$ & 25 \\
\hline $\begin{array}{l}\text { *So. Calif. } \\
\text { Counties }\end{array}$ & $12,368,500$ & $13,234,100$ & $15,328,200$ & 24 \\
\hline $\begin{array}{l}\text { +Los Angeles } \\
\text { Metropolitan } \\
\text { Area }\end{array}$ & $9,925,900$ & $10,323,300$ & $11,706,000$ & 18 \\
\hline Source: & \multicolumn{4}{|c|}{$\begin{array}{l}\text { 1970: California State Department of Finance, Provisional } \\
\text { Projections of California Counties to } 2000 \text {, 1971. } \\
1975 \text { and 1985: California State Department of Finance, } \\
\text { Population Projections for California Counties 1975- } \\
\text { 2020, 1977. }\end{array}$} \\
\hline
\end{tabular}

published in 1977 indicate the rate of growth for this period will be somewhat less with an expected increase in the population of California of $25 \%$. The Los Angeles Metropolitan area (including the counties of Los Angeles, Orange, Riverside, San Bernardino, and Ventura) is expected to increase 18\% (see Table 13). Since this area provides the overwhelming proportion of winter visitors, the lower rate of increase should result in a lower rate of increase in the total ski market and in the demand on the facilities at Mammoth.

The growth of winter activities can affect the growth of summer activities. People who build a second home for use when skiing are more likely to visit the area again in the summer. Because of the impact on the environment, the Forest Service has begun to set limits on some activities. By not constructing new campgrounds or enlarging existing ones, the number of campers will remain fairly constant. Fishing and boating activities are constrained by the availability of water resources. 


\subsection{Power and Heating}

The area's power requirements are supplied by investor owned Southern California Edison Co. (SCE). Hydroelectric generation within Mono Co. (21 MWe) is augmented by two $115 \mathrm{KV}$ transmission 1 ines from the south to this northern extremity of the SCE system (Haven 1976, pp. 16, 17). In addition, an intertie between the Los Angeles Department of Water and Power's hydroelectric plants in Owen Gorge and the SCE was recently effected. No significant local generation or transmission facilities, except possibly those related to potential geothermal development, are planned. SCE's analysis indicates that needs may be met most economically by system additions outside the area.

During 1972 Mono County's generated power was 72 million KWH (Table 14) and 88 million KWH were sold (Table 15). In contrast, neighboring Inyo County's generation and use were 747 and $81 \mathrm{milli}$ ion $\mathrm{KWH}$ respectively. Referring to Table 1 concerning population, it is apparent that Mono County's per capita (resident) consumption is approximately three times that of Inyo county. This is due in large part to the Mammoth winter use for lighting and heating.

Peak demand in the general Mammoth service area grew from 1.5 MWe in 1960 to 41 MWe in 1975 (Table 16). 1976 and 1977 peaks were relatively low due to unseasonable snow and winter temperature conditions. 1980 Mammoth Village area peak demand has been estimated to be in the order of 53 MWe, with a continued rise to 78 MWe by 1985 (USDA Forest Service 1977). Another study indicates that the 1980 peak demands for electric space and water heating alone will be 41 MWe and 8 MWe respectively (Sims and Racine 1977, p. 3).

A 1976-1977 study of Mammoth Lakes Village determined that $88 \%$ of space heating capacity and 74\% of water heating capacity were served by electricity (Sims and Racine 1977, p. 3). The balance was fueled by LPG supplied by three companies in the Mammoth area. SCE considers that the Mammoth area is the only area in the county which will see significant increased demand (USDA Forest Service 1978, p. 26).

TABLE 14

ELECTRICITY GENERATION AND CAPACITY (1972)

\begin{tabular}{|c|c|c|c|}
\hline & $\begin{array}{l}\text { No. of Hydro } \\
\text { Plants }\end{array}$ & $\begin{array}{c}\text { Capacity } \\
\text { (MWe) }\end{array}$ & $\begin{array}{l}\text { Generation } \\
(\text { KWH })\end{array}$ \\
\hline $\begin{array}{l}\text { Mono County } \\
\text { Inyo County }\end{array}$ & $\begin{array}{r}3 \\
13\end{array}$ & $\begin{array}{r}21.4 \\
152.4\end{array}$ & $\begin{array}{r}71,810,962 \\
746,650,807\end{array}$ \\
\hline
\end{tabular}

Source: K. F. Haven, The 1972 Flow of Electrical Energy in California and its Relationship to Selected County Level Characteristic Parameters, (Livermore, Calif: Lawrence Livermore Laboratory, 1976), pp. 16, 17. 
TABLE 15

ELECTRICAL ENERGY SALES IN 1972

$$
\text { (in } 1,000 \text { 's) }
$$

Residential KWH
Commercial

KWH $\$$
Industrial

KWH $\$$
Public

KWH $\$$
Total

KWH $\$$

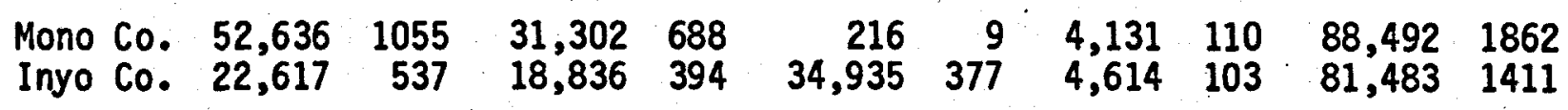

Source: Same as Table 14, pp. 44, 45.

TABLE 16

MAMMOTH VILLAGE AREA PEAK POWER DEMANDS

(in MWe)

$\begin{array}{rrrr}1960 & 1.5 & 1969 & 9.6 \\ 1961 & 1.7 & 1970 & 13.2 \\ 1962 & 2.1 & 1971 & 15.6 \\ 1963 & 2.4 & 1972 & 21.6 \\ 1964 & 4.2 & 1973 & 30.0 \\ 1965 & 4.9 & 1974 & 34.8 \\ 1966 & 7.2 & 1975 & 41.0 \\ 1967 & 7.7 & 1976 & 37.0^{*} \\ 1968 & 9.8 & 1977 & 28.0^{*}\end{array}$

*1976 and 1977 peaks are relatively low due to unusually high winter temperatures and poor snow conditions.

Source: 1960-1968: Unpublished Forest Service Draft Environmental Statement, 1977, quoting SCE records.

1969-1977: A. V. Sims and W. C. Racine, Feasibility of Geothermal Space/Water Heating for Mammoth Lakes Village, California. Final Report for Period September 1976-September 1977 (Pasadena, Calif.: The Ben Holt Co., 1977), p. 36.

The Ben Holt Company, under contract with the U.S. Department of Energy, investigated the feasibility of utilizing geothermal effluent to satisfy heating needs in Mammoth Lakes Village. The production site would be a 90 acre parcel some 3 miles east of Mammoth, owned by Magma Energy, Inc. Nine shallow wells were drilled between 1959 and 1962 on this site. Geothermal fluids would be run through a heat exchanger and energy would be transferred to a closed fresh water loop system for the village. The Holt study considered both a 52 MWe facility for space and water heating and a 60 MWe unit which would have added capacity for pool heating and snow melting. Initial costs in 1977 dollars were estimated at $\$ 14.6$ million for the former and $\$ 15.2$ million for the latter facility exclusive of land and costs incurred by consumers on their premises (Sims and Racine 1978, p. 9). 
This study projected that the Mammoth heating demand for total space and water heating alone will be 58 MWe in 1980, 84 in 1990, and 122 in 2000 (Sims and Racine 1977, p. 3). Projected unit costs based on 1977 dollars for the first year of operation are:

\begin{tabular}{|c|c|c|c|}
\hline & $\begin{array}{l}\text { (Cents } \\
\text { Space and Water } \\
\text { Heating Only } \\
\end{array}$ & $\begin{array}{r}\text { per KWH) } \\
\text { All } \\
\end{array}$ & $\begin{array}{l}\text { Heating } \\
\text { Uses }\end{array}$ \\
\hline $\begin{array}{l}\text { ivestor Owned } \\
\text { blicly Owned }\end{array}$ & $\begin{array}{l}4.26 \\
2.89\end{array}$ & & $\begin{array}{l}3.22 \\
2.24\end{array}$ \\
\hline
\end{tabular}

Electric energy costs are quoted as $3.41-4.22$ cents per KWH. Comparable LPG was costed at an equivalent of 3.17 cents per thermal KWH (Sims and Racine 1977, p. 71). The break-even point, taking into consideration on-consumer premises costs, ranges from six years for the investor owned space and water heating alternatives to one year for a publicly owned district supplying all heating requirements.

The California Energy Commission is currently funding a pilot demonstration project, scheduled for completion in the Spring of 1979 at Casa Diablo. A county permit has been issued for a new exploratory well at this site. (see Chapter 2).

\subsection{County Finance}

Mono County's growth rate is highlighted by its growth in assessed valuation (Table 17). In the five year period from 1972 to 1977 , assessed valuation increased $70 \%$ and virtualiy caught up with more populous Inyo County; in comparison, California grew $58 \%$.

TABLE 17

\section{ASSESSED VALUATION $\left(\$ 1,000^{\prime} \mathrm{s}\right)$}

$\begin{array}{lrrr} & \text { FY } 68 & \text { FY } 172 & \text { FY } 77 \\ \text { Mono County } & 38,866 & 54,726 & 92,975 \\ \text { Inyo County } & 49,532 & 76,189 & 107,499 \\ \text { California } & 45,977,861 & 58,529,133 & 92,556,819\end{array}$

Source: California Controllers Office, Annual Reports of Financial Transactions Concerning School Districts of California, Tables 1 a 2, FY 1967-1977.

While the assessed valuation for $1977-1978$ has grown to a level of $\$ 102$ million, it still is indicative of a relatively low tax base (Mono County Final Budget 1977-1978). 
TABLE 18

SUMMARY OF COUNTY REVENUES

$\left(\$ 1,000^{\prime} s\right)$

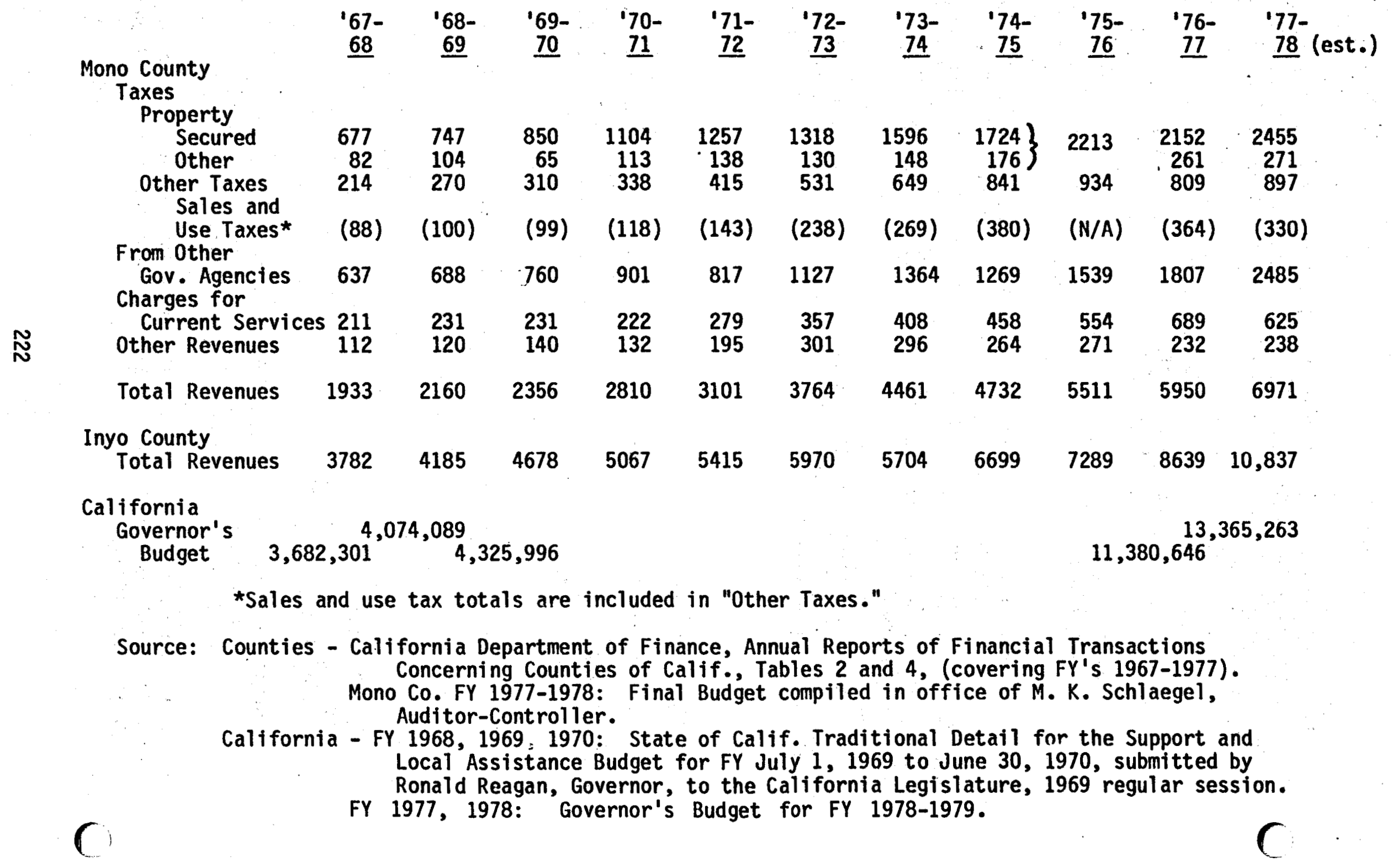




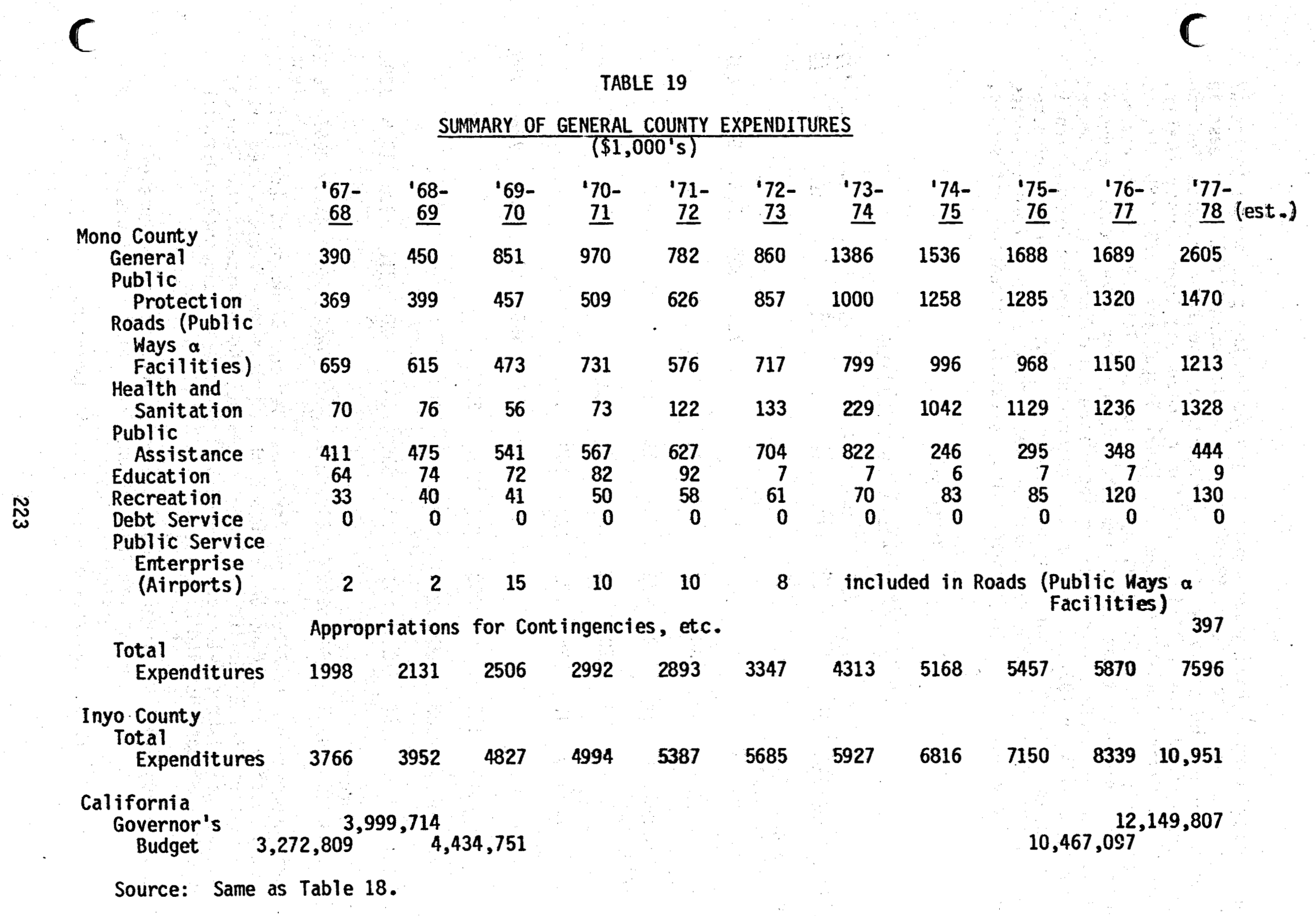


Mono County revenues have grown substantially during the past decade to the 87 million level for fiscal year 1978 (Table 18). The county's 261\% increase in revenues during the ten year period approximates the $263 \%$ increase for the state and exceeds the $187 \%$ increase for neighboring Inyo County (Calif. Controllers Office 1967-1977; Mono Co. Final Budget 1977-1978; USDA Forest Service 1978 , p. 20). As shown by Table 18, the largest current revenue sources are property taxes (39\%) and funds from other governmental agencies $(36 \%)$. Both of these sources were of increasing significance (up from 36 and $31 \%$ respectively in 1977). The current uncertainty regarding Proposition 13 is of course a major factor with respect to the future. Funds from other governmental agencies include revenues derived from the use of Forest Service land. These uses included timber sales, grazing, recreation activities,

TABLE 20

AVERAGE DAILY SCHOOL ATTENDANCE

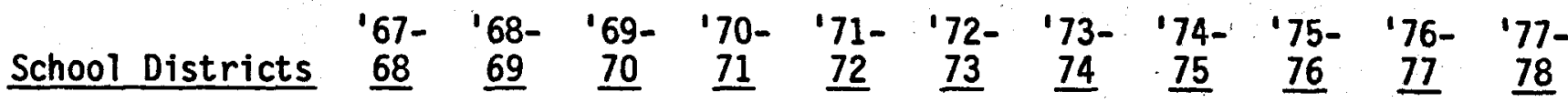

Mono County

Eastern Sierra

Unified

Antelope

$\begin{array}{lllllll}\text { Elementary } & 83 & 86 & 82 & 79 & 73 & 85\end{array}$

Benton

$\begin{array}{lllllll}\text { Elementary } & 64 & 72 & 73 & 79 & 85 & 84\end{array}$

Bridgeport

$\begin{array}{lllllll}\text { Elementary } & 81 & 70 & 90 & 107 & 124 & 128\end{array}$

Lee Vining

$\begin{array}{lllllll}\text { Elementary } & 118 & 126 & 122 & 123 & 140 & 155\end{array}$

Mammoth

Unified

Mammoth

$\begin{array}{lllllll}\text { Element ary } & 188 & 221 & 250 & 282 & 318 & 393\end{array}$

Mono Co. High

School

$\begin{array}{llllll}207 & 206 & 234 & 247 & 255 & 297\end{array}$

Total

$741 \quad 781 \quad 851$

$851 \quad 917$

715

$\begin{array}{llll}585 & 563 & 569 & 601\end{array}$

$\begin{array}{lllll}455 & 631 & 667 & 736 & 700\end{array}$

Total California

$\begin{array}{llllllllllll}\left.\text { (in } 1,000^{\prime} s\right) & 4923 & 4998 & 5091 & 5210 & 5216 & 5203 & 5222 & 4666 & 4699 & 4667 & 4622\end{array}$

Subsequent to FY 1973-1974, the Antelope, Benton, Bridgeport, Lee Vining and a portion of the Mono Co. High School Districts were consolidated into the Eastern Sierra Unified District. Likewise, the balance of the Mono Co. High School District was consolidated with the Mammoth Elementary District into the Mammoth Unified District.

Source: 1967-1977: California Controllers Office, Annual Reports of Financial Transactions Concerning School Districts of California, Table 2.

1978: California Department of Education. 
TABLE 21

MONO COUNTY SCHOOLS GENERAL FUND INCOME

$(\$ 1,000)$

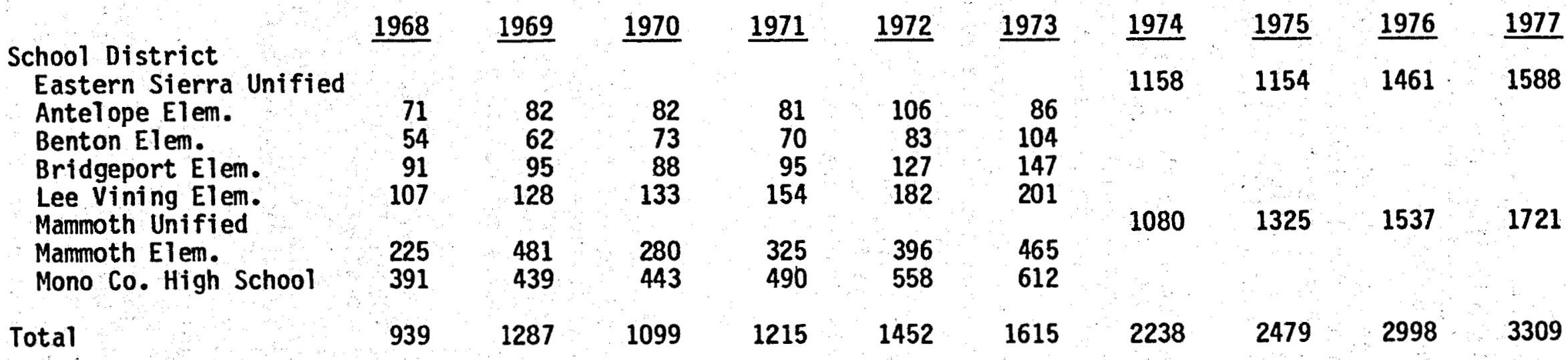

TABLE 22

MONO COUNTY SCHOOLS GENERAL FUND EXPENDITURES $(\$ 1 ; 000)$

\begin{tabular}{|c|c|c|c|c|c|c|c|c|c|c|}
\hline & 1968 & 1969 & 1970 & 1971 & 1972 & 1973 & 1974 & 1975 & $\underline{1976}$ & 1977 \\
\hline $\begin{array}{l}\text { Antelope Elem. } \\
\text { Benton Elem. } \\
\text { Bridgeport Elem. } \\
\text { Lee Vining Elem. }\end{array}$ & $\begin{array}{r}69 \\
50 \\
88 \\
102\end{array}$ & $\begin{array}{r}71 \\
61 \\
99 \\
114\end{array}$ & $\begin{array}{r}79 \\
69 \\
90 \\
135\end{array}$ & $\begin{array}{r}82 \\
73 \\
86 \\
143\end{array}$ & $\begin{array}{r}90 \\
81 \\
117 \\
164\end{array}$ & $\begin{array}{r}95 \\
95 \\
149 \\
211\end{array}$ & & & & \\
\hline Mammoth Unified & & & & & & & 680 & 1373 & 1590 & 1667 \\
\hline $\begin{array}{l}\text { Mammoth Elem. } \\
\text { Mono Co. High School }\end{array}$ & $\begin{array}{l}199 \\
378\end{array}$ & $\begin{array}{l}269 \\
384\end{array}$ & $\begin{array}{l}269 \\
463\end{array}$ & $\begin{array}{l}305 \\
461\end{array}$ & $\begin{array}{l}372 \\
485\end{array}$ & $\begin{array}{l}485 \\
619\end{array}$ & & & & \\
\hline
\end{tabular}

Source for Tables 21 and 22: California State Controllers Office, Annual Reports of Financial Transactions Concerning School Districts of California. Table 3 (covering fiscal years 1967-1977) 
mineral extraction, and power development. In FY 1976 Mono County received in excess of $\$ 98,000$ from USFS receipts. Additionally, the county received some $\$ 269,000$ in lieu of FY 1976 property taxes from federal agencies as mandated by PL94-565 (USDA Forest Service 1978, p. 20).

Mono County expenditures have increased in the last decade from $\$ 2.0$ million in FY 1968 to an estimated $\$ 7.6$ million level for FY 1978 or an increase of $280 \%$ (Table 19) All categories except public assistance support have remained relatively constant while health and sanitation expenditures have grown 1800\% to $\$ 1.3$ million (Calif. Dept. of Finance 1967-1977; Mono County Final Budget 1977-1978).

Mono County school attendance has steadily increased over the past decade from an average daily attendance (ADA) of 741 for FY 1968 to 1301 for FY 1978 (Table 20 ). This represents a $76 \%$ increase as compared with a $6 \%$ decrease for the state. As might be anticipated, attendance growth in the Mammoth area has been quite significant.

Mono County school funding and expenditures have seen a comparable steady increase (Tables 21 and 22). In addition to increased ADA, the approximate doubling of revenues per student reflects a dramatic increase in school support for the county. Since more than $70 \%$ of school revenues have come from county property tax sources, the impact of Proposition 13's roll back of property valuations for tax purposes will be significant. As most expenditures are relatively fixed, decreases in teaching staffs are anticipated (Mono Co. Superintendent of Schools, July 1978).

\subsection{Land Use}

Since the completion of Long Valley Dam and related facilities, construction in the area has been primarily related to housing and public works. The latter includes the typical road and utility improvements and maintenance projects. The small airport some 9 miles southeast of Mammoth has been undergoing modest development and more is planned. A small number of restaurants, shops and other retail sales and service buildings cont inue to be built in Mammoth Lakes.

Residential construction, centered in Mammoth Lakes, was relatively brisk during the last of the 1960's and the beginning of the 1970's (Table 23). Sanitary waste treatment and water availability problems resulted in a building moratorium which, coupled with the recession's impact on the Los Angeles markets' discretionary expenditures, resulted in substantial slowing until the current year. These limitations have now been removed and the pace of 1978 residential construction has increased.

Since construction has been constrained, and that which has occurred is "upper-end" with a substantial percentage of luxury type condominiums, housing for construction or other temporary residents is very limited. Major construction project housing needs in Mono and Inyo Count ies have traditionally been met by construction of temporary housing projects or camps. Fortunately, the prime construction and tourist seasons do not coincide; however moderately priced temporary housing is at a premium at all times. 
TABLE 23

RESIDENTIAL CONSTRUCTION IN MONO COUNTY (Building Permits)

\begin{tabular}{|c|c|c|}
\hline $\begin{array}{l}1967 \\
1968 \\
1969 \\
1970 \\
1971 \\
1972\end{array}$ & $\begin{array}{l}230 \text { units } \\
336 \\
437 \\
400 \\
528 \\
\text { NA }\end{array}$ & $\begin{array}{l}1973 \\
1974 \\
1975 \\
1976 \\
1977\end{array}$ \\
\hline
\end{tabular}

Source: Mono County Planning and Building Department

The Mammoth Lakes area does have a good percentage of transient-type accomodations which are potentially available to skilled workers and technicians with an ability to pay tourist-based rates (Table 24). The capacity of Mammoth Lakes as zoned by Mono County, provides for a fivefold Increase in residential units (UCLA 1972a, p. 84).

\section{TABLE 24}

EXISTING RESIDENTIAL UNITS (1972) (Mammoth Lake Village Area)

Single family residence

Apartments

Condomi ni ums

Dormitory

Mobile homes

Hotel, motel

Total 1

Source: Mono County Planning and Building Department
794

213

1,279

291

212

728

3,517

As indicated by Fig. 2, the federal government dominates land ownership in the KGRA with some $75 \%$ of the acreage. The U.S. Forest Service, as shown in Table 25, is the largest shareholder of both the KGRA and land which may be leased for geothermal development. Due to the extent and location of Forest Service land, coupled with its traditional management role in a recreation based setting, the Forest Service may be considered to be a most influential organization in determining the destiny of geothermal and other development in the area. The federal government is also the major owner of land elsewhere in Mono and Inyo Counties (Table 26). 
TABLE 25

KGRA LAND OWNERSHIP (acres)

Forest

Total KGRA

Service

Proposed Lease Area

253,000

26,000

BLM
92,000
$2,000^{b}$

State $^{2}$

LADWP Private

Total

a Consists mainly of lands beneath the surface of Mono Lake

bIncludes lands currently leased

Source: Federal Resgister, Vol. 36, No. 65, p. 6442, April 3, 1971; USDA Forest Service, Forest Visitors Map, Inyo National Forest, 1972; and interviews with U.S. Forest Service.

Land use in the study area is essentially controlled by the Forest Service, the Bureau of Land Management (BLM), the Los Angeles Department of Water and Power, and Mono County. The Forest Service and the BLM control use under their jurjsdictions through permit systems. Uses of federal land include ski operations, lodges, and cabins. The Mono County Planning Commission controls use of private land through application of its General Plan, zoning regulations, and the Uniform Building Code. The General Plan reflects the Monoplan approved by Mono County in 1976, which is a comprehensive plan for the area consisting of approximately the southern two-thirds of the KGRA (SWR 1975, pp. 28-29). The high densities permitted under the General Plan for Mammoth Lakes are of concern to residents (UCLA 1972a, pp.82-86).

TABLE 26

\section{$\frac{\text { COUNTY LAND OWNERSHIP }}{\text { (in } 1,000 \text { acres) }}$}

Federal State County City Schools Districts Public Private Total

$\begin{array}{lccccccrrr}\text { Inyo Co. } 4,775 & 106 & 7 & 248 & <1 & <1 & 5,136 & 1,354 & 6,490 \\ \text { Mono Co. } 1,187 \mathrm{~b} & 14 \mathrm{c} & 4^{\mathrm{c}} & 60^{\mathrm{a}} & <1 & 185^{\mathrm{d}} & 1,450 & 559 & 2,009 \\ \text { Calif. } & 44,048 & 2,505 & 759 & 922 & 87 & 743 & 49,064 & 52,500 & 101,564\end{array}$

aIncluding Los Angeles Department of Water and Power

bNational Forests (Inyo and Toiyabe) $=1,154,494$ acres

BLM (public domain) $=30,320$ acres

cState and county highways and roads $=7,464$ acres

dprimarily fire protection districts

Source: State of California, State Lands Commission. Public Land Ownership in California, 1977, December 1977, California, Office of State Controller, Annual Report of Financial Transactions, fiscal year 1971-1972. 


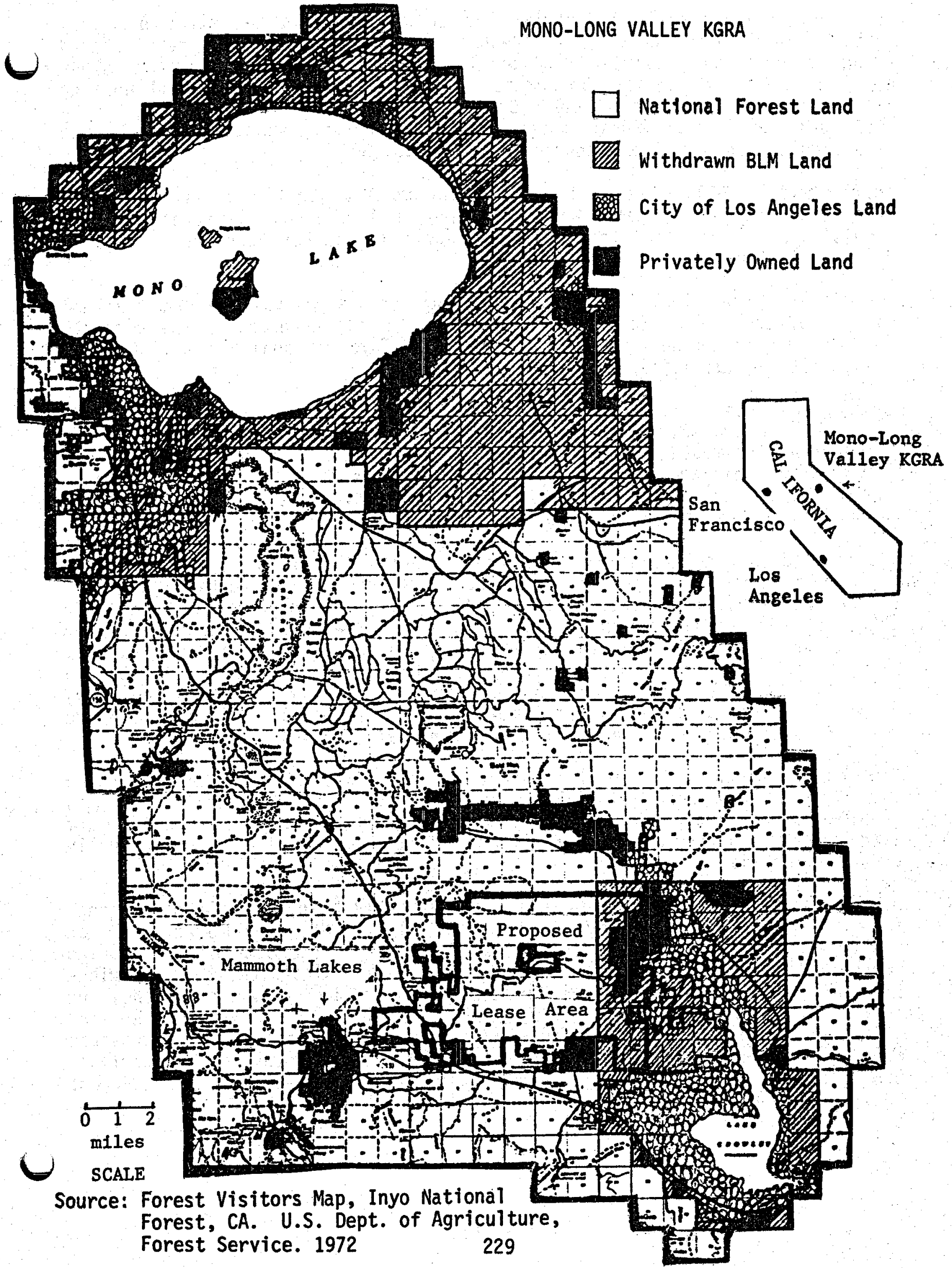


Residential, commercial, industrial and utility uses in the study area are centered in Mammoth Lakes. The greatest number of these uses are clustered along or near State Route 203 which runs from U.S. 395 into Mammoth Lakes. Lee Vining is next in size to Mammoth followed by a number of small housing clusters including those of McGee Creek, South Landing/Whiskey Creek, Crestview, and June Lake. All of these small rural housing settlements, with the exception of June Lake, are contiguous with U.S. 395.

Approximately 200 acres of land adjacent to Mammoth Lakes are privately owned and used for lodges, cabins, boating, and related activities. Public acquisition of this land for public recreational use has been the subject of discussions for many years.

Agricultural use, including cattle grazing, occurs in the eastern flatland portion of the KGRA. Forest products are primarily produced in the westerly section containing the Forest Service-managed Inyo National Forest. Mineral production, as was noted above, is very limited.

Recreational uses predominate over virtually the entire area. Winter sports center on the two ski areas of Mammoth and June Lake. Summer uses target the lake areas of Mammoth, June, Crowley, Mono, and Convict. Other popular areas for camping, hiking and picnicking include Reds Meadow, Devils Postpile, McGee/Hilton Creek, Agnew Meadows, and Hot Creek. The John Muir and San Joaquin Wilderness Areas abut the KGRA on the southwest.

Transportation uses consist of the usual highway and roadway systems as well as a small privately operated airport. U.S. Route 395, running generally north-south through the study area, is the principal transportation artery for goods and for travel from the Los Angeles area market. 1977 traffic flow per day at the intersection of 395 and State Route 203 is represented by a peak flow of 7,000 vehicles and an average of 3,200. State Route 203, running westerly from U.S. 395 to and through Mammoth Lakes, is estimated to carry at its intersection with Minaret Summit, a peak flow of 10,000 and an average daily flow of 6,400 vehicles (Sims and Racine 1977, p. 90).

Non-federally controlled land adjacent to the proposed lease area includes land for the Hot Creek Fish Hatchery which is leased by the City of Los Angeles to the state. This hatchery is considered unique by some as the warm water produces conditions which allow the trout to breed over an unusually extended period.

Within the 28,390 acre area of the KGRA currently being considered for geothermal leasing, only 90 acres are privately owned. The Forest Service controls more than 26,000 acres or $93 \%$ with BLM and the City of Los Angeles controlling virtually all of the remainder. Table 25 indicates this distribution of ownership. The private land is controlled by Magma Energy, Inc. and is the site of the current geothermal heating pilot program. None of the land within the proposed lease area is currently classified as a special interest area under any one of the various laws covering archaeological, historical, biological, wilderness, scenic, or other special protected areas (USDA Forest Service, 1978). 
A number of plans have been developed for the study area. The most recent of these include the following:

A. Monoplan

This is a regional comprehensive land management plan covering approximately the southerly two-thirds of the KGRA. The center of focus is the Mammoth Lakes area. The plan was prepared by Monoplan Associates, a private consulting group and was approved by the Mono County Board of Supervisors in December 1976. The Forest Service, initially a partner in the preparation of the plan, took the position that the Monoplan had a number of deficiencies and proceeded to prepare a plan of its own. These deficiencies had to do with provisions of the National Environmental Policy Act, Resources Planning Act, and other federal legislation.

B. Land Management Plan, Mammoth-Mono Planning Unit

This is a draft comprehensive national forest land use plan, prepared in 1978, which when adopted will replace the Forest Service's Multiple Use Management Plan. The plan includes the southwesterly portion of Mono County together with contiguous portions of Madera County to the west and Fresno County to the south. The most significant areas within the KGRA are embraced by the plan. The plan presents six alternative sub-plans with varying levels of resource utilization. The recomnended alternative sub-plan provides for geothermal development in certain specific locations. These are fundamentally the Grandfather lands and small contiguous areas in the vicinity of Little Antelope Valley (USDA Forest Service 1978).

C. Mono County Regional Transportation Plan

This is a regional plan focusing on transportation needs in the Mammoth Lakes and June Lake areas. It treats the establishment of a Mammoth Village public transportation system as well as roadways and airports. The most recent update is dated September. 28, 1978 .

D. June Lake Loop Plan

The June Lake Loop Plan was prepared in 1974 to guide land utilization in the area of June, Silver, and Grant Lakes and was adopted by the county in 1974 .

E. Mammoth Lakes/UCLA Project

This work is cited here in that, while not truly a plan, the study should be considered as a planning document. The study, centering on Mammoth Lakes Village, identifies five alternative futures and their implications. It was performed as a University of California study in 1972 and was funded by the Friends of Mammoth, Inc., National Science Foundation, and others (UCLA 1972a, 1972b). 


\subsection{Infrastructure}

Decision making in the study area is very complex. One finds the typical marble cake complex of many interacting organizations, public and private, which constitute the power structure of the area. Decision making by numerous organizations on the various governmental levels is fragmented. Coordination amongst these various groups is reported to be at times less than sufficient to rationally internalize the values and needs of various constituencies and to plan for achievement of commonly accepted goals. Additionally, this fragmentation, duplication, and overlap create conflicts and uncertainties. Long lead times are required, ranging up to four years for a Forest Service use permit, which tend to stifle optimal developmental progress where such progress is in fact perceived as beneficial. In recognition of the need for coordination, the Inyo-Mono Association of Government Entities (IMAGE) was established in 1973. This organization fundamentally provides a vehicle for joint planning by the two county governments. Additionally, the Owens Valley Interagency Comittee provides a potential forum for all levels of government.

As the manager of the vast bulk of the land, the Forest Service plays a dominant role. With no municipal government, the county is in position to control geothermal development on private land. As the seat of county government is outside the KGRA, and 50 miles north of Mamnoth Village, some feeling exists that local attitudes toward development are not adequately considered. Since the County Board of Supervisors' role is to be responsive to the needs of the county in its entirety, and the Forest Service's role is to manage its land and recreational resources effectively for all, regardless of where the beneficiaries live, opportunity exists for perception by the local communities that their needs are not always protected.

The county has no specific regulations for geothermal development. This has been a concern of a number of Mammoth area residents who feel that specific regulations should be adopted prior to exploration. Exploration and development are permitted under the county zoning ordinances in general purpose districts, subject to issuance of a use permit. The process is governed by the provisions of the California Environmental Quality Act of 1969 which requires an environmental assessment and the usual findings. The three most recent use permits for geothermal exploration were issued after the filing of negative declarations by the county as the lead agency. The only formal objections were those by archaeologists (Mono Co. Planning Director 1978).

Exploration and development on federal lands are similarly subject to the provisions of the National Environmental Policy Act of 1970. The Forest Service or BLM, whichever is manager, acts as the lead agency. Leasing regulations and special use permit procedures are employed. Other pertinent federal acts include the Geothermal Steam Act, The Forest and Rangeland Renewable Resource Act, and the National Forest Management Act.

One would be remiss for not citing another significant force in the complex institutional framework. The Los Angeles Department of Water and Power, through its strategic ownership of land and water rights within the study area as well as its position as a major electric generating utility in the area and its interaction with the Southern California Edison Co., is in position to exert some influence on development and utilization of geothermal resources for electric power. 
The following is a partial listing of governmental, private, and special interest groups having significant local presence which illustrates the institutional and organizational complexities noted above (see Table 27 also).

Federal

National Park Service

Forest Service, Inyo National Forest, Manmoth Lakes Ranger

District, and Lee Vining Ranger District

Bureau of Land Management

State

Department of Fish and Game

Department of Forestry

Department of Public Health

Department of Water Resources

Division of Highways, District 9, Department of Transportation

Energy Comission

Historic Preservation Office

Lahontan Regional Water Quality Control Board

Native American Heritabe Comission

Public Utilities Commission

Local Government

Board of Supervisors

Department of Health

Eastern Sierra Unified School District

Environmental Review Comittee

Fish and Game Advisory Comittee

Great Basin Unified Air Pollution Control District

June Lake Advisory Council

Los Angeles Department of Water and Power

Mamnoth Advisory Council

Mammoth County Water District

Mamoth Lakes Fire Department

Marmoth Unified School District

Planning and Building Department

Planning Comission

Pollution Control Board

Road Department

Community Action, Special Interest Groups, and Others

Continental Telephone Co.

Friends of Marmoth

Friends of the Earth

Interagency Committee on Owens Valley Wildiffe

Inyo-Mono Association of Government Entities (IMAGE)

Mammoth Lakes Chamber of Cormerce

Mammoth Lakes Motel and Lodge Association

Owens Valley Interagency Committee

National Audubon Society, Mono Lake Comittee

Sierra Club

Southern California Edison Co. 
TABLE 27

PUBLIC AGENCIES INVOLVED IN THE GEOTHERMAL RESOURCE DEVELOPMENT PROCESS

(Jurisdiction)

Primary Area of
Agency Interest

Land Use

Operations Requi rements:

Enforcement

Air Quality Standards:

Enforcement

$\underset{\$}{\omega}$

Water Protection:

Discharge Requirements

Fish and Wildlife Protection

Solid Waste Disposal

Water Resources Development

Forest Watershed Protection

Intra-Governmental Coordination

\section{California}

State Lands Commission

Division of $0 i 1$ and Gas

Air Resources Board

State Water Resources

Control Board

Department of Fish and Game

Solid Waste Management Board

Department of Water Resources

Department of Forestry

Geothermal Resources Board
Federal

Department of the Interior

Bureau of Land

Management

Department of the Interior/U.S. Geological Survey

Environmental Protection Agency

Envïronmental Protection Agency

Department of the Interior/U.S. Fish and Wildlife Service

Department of Agriculture Forest Service

Geothermal Environmental Advisory Panel
Regional or Local

County Planning

Department

Local Air Pollution Control District

Regional Water Quality Control Board ( 


\section{PUBLIC AGENCIES INVOLVED IN THE GEOTHERMAL RESOURCE DEVELOPMENT PROCESS} (Jurisdiction)

Primary Area of
Agency Interest

Pollution Control

Energy Research and Development: Conservation of Resources

Siting Approval of Power Plants: Rate Regulating

\section{Clearinghouse for Environmental} Impact Reports

Occupational Health and Safety Standards: Enforcement

Radioactive Waste Disposal Control

Public Securities - Issuance and Trading Regulation

Property Tax Assessment

Cultural Resources

\section{California}

State Energy Resources Conservation and Development Commission

\section{California Public Utilities Commission, CERCDC}

Governor's Office of Planning and Research

Department of Industrial Relations

Department of Health

Corporations Commission

State Board of Equal ization

Historic Preservation Office, Native American Her. Comm.
Federal

Regional or Local
Envi ronmental Protection Agency

\section{Department of} Energy

\section{Federal Power}

Commission

Occupational Safety and Health Admi nistration

\section{Securities and Exchange Commission}

Source: C.D. Fredrickson, Analys is of Requirements for Accelerating the Development of Geothermal Energy Resources in California (Pasadena, California: Jet Propulsion Laboratory, 1977), pp. 2-24. 


\subsection{GEOTHERMAL DEVELOPMENT AND POTENTIAL IMPACTS}

\subsection{Scenario}

Potential socioeconomic impacts and concerns are of course functions of such factors as plant location, size, type, scheduling, and use. Since much remains to be determined concerning the reservoir and related plant design, we must make assumptions with which to explore the potential for impacts and concerns. Three illustrative models are:

1. 50-100 Mwe facility to serve local heating requirements (district heating).

2. 50-100 Mwe facility to serve local electrical requirements.

3. A larger than a 100 MWe facility to serve both local and distant markets.

For each of these alternatives, it is assumed that exploration would start in approximately two years and that the first unit would be on-line approximately five years later. Facilities would be located easterly of U.S. Route 395 in the Casa Diablo or Little Antelope Valley areas with land requirements in the order of 100 to 700 acres per 100 MWe. Approximately forty wells per 100 MWle may be required. On-site manpower for construction would be in the order of 20-100 per year with 20 plant operational people required per 100 MWe. Plant life is assumed to be 30 years.

The capital cost of the electric power facility in 1978 dollars is assumed to be $\$ 70-115$ million per 100 MWe. The comparable cost of the district heating alternative is $\$ 17-20$ milion. Taxes, or their equivalents, without adjustment for post-Proposition 13 impact or investor ownership would be $\$ 300-600 \mathrm{~K}$ per 100 MWe for electrical power production and $\$ 80-100 \mathrm{~K}$ for the district heating plant.

\subsection{Issues and Effects}

Resource use is always a controversial topic. Development and utilization of geothermal resources in the beautiful Mono-Long Valley area is no exception. As has been noted, the underlying position of informed people in the area may be interpreted as striving for wise use, not non-use. Through various means, including a workshop attended by local concerned citizens and interviews, a listing of some of the potential issues, concerns, and effects has been prepared. It is not the purpose here to evaluate or assess these factors. Since it appears desirable, however, to categorize them by indicating which ones could serve as barriers or constraints which would preclude geothermal development, some degree of appraisal was necessary. Certain of the issues may seem trivial. They are identified, however, as they indicate concerns which should be addressed in order that the implied questions may be objectively answered rather than to await surprise in the press or other public forum. The issues enumerated below are not mutually exclusive. Many of the concerns are fundamental to several categories. Brief comments concerning these issues and effects follow the enumeration. 
A number of the issues and concerns pre-existed discussion of possible geothermal resources. It is important to recognize this as the satisfaction of need systems here becomes more complex. Examples include concerns regarding growth, resource exploitation and employment. Some feel that growth is inherently bad and that many of the soclai and economic problems of the area are the result of uncontrolled growth. Many originally came to the area for the quality of life found here. Yet certain of these people have difficulty making ends meet and view any development that would make the local labor market more vulnerable as negative, or conversely, any action that would provide enhanced employment opportunities for them as positive. With the history of water exportation in the area, any exportation or use for others historically tends to be viewed with concern.

As a further example of pre-existing attitudes, let us turn to a 1972 study. A team of UCLA researchers identified the following key issues for the Mammoth Village area (UCLA 1972a, p. h):

1. Town atmosphere

2. Deterioration of natural environment

3. Variety and quality of recreational opportunities

4. Variety of goods and services

5. Transportation

6. Snow removal

7. Distribution of government control

8. Water supply and waste disposal

9. Ups and downs: the peak loading problem

10. Long term stability/instability

11. Attractive economic and cultural opportunities

12. Desire for local control

The same study suggested that local citizens felt that the environmental quality of the area was rapidly deteriorating as the direct result of increased development. During 1978, an opinion survey of neighboring Inyo County property owners seemed to complement these findings. Only $36 \%$ of the respondents felt that industry would be an asset. Fifty-eight percent felt that existing retail business was sufficient. Sixty-eight percent said that population growth and traffic mean deterioration in the quality of life (Inyo Co. Property Owners Assn. 1978). On the national level, concern regarding development's impact on environmental quality is reflected by the reporting of a Gallup poll in an Inyo County newspaper (Inyo Register 1978):

The prevalent attitude among those interviewed is support for the type of land use that would preserve the national environment. This sentiment is held by a majority of people regardless of their sex and socio-economic background and regardless of the region of the country in which they live.

More specifically, overwhelming majorities would like to see more emphasis placed on the protection of wildlife and ecology, the protection of scenery and natural character and the protection of areas of historic impor tance. At the same time a majority would like to see less emphasis placed 
on commercial development like motels and restaurants. A majority would also like to see less of, or the elimination of, unrestricted open areas for off-road vehicles.

Consistent with the emphasis on environmental protection is the finding that a great majority feel surface scars due to underground pipelines, mining, power generating plants and electrical transmission lines have a negative effect on one's enjoyment of the desert scenery.

At this time there is no strong indication however that the prevelant attitude in the study area is specifically opposed to geothermal development. Many are not adequately informed. As one spokesperson indicated, "No one is opposed to geothermal, those that know are just concerned."

With this as background, the following listing of issues and concerns may be envisaged:

ISSUES AND CONCERNS

\section{Social/Demographic}

1.1 Constraints--Major Concerns

*1.11 Change in character and quality of life: insertion of industrial use in area of great natural tranquility and beauty

*1.12 Social equity: balance between payors and payees

1.2 Subsidiary--Secondary Concerns

1.21 Change in composition of the area with respect to such elements as:

1.211 resident and transient populations

1.212 employment--primary and secondary

1.213 age, sex, ethnicity

1.214 skills

1.215 turnover

1.22 Change in demand, supply, pricing of housing

*1.23 Value of long term recreation resource vs. shorter term geothermal resource

*1.24 Exportation of resources from the valley 


\section{Infrastructure}

\subsection{Constraints--Major Concerns}

Capability of government to effectively manage geothermalrelated development

\subsection{Subsidiary--Secondary Concerns}

*2.21 Local control (non-local control shifting balance of power further away)

*2.22 Capability of local government to effectively assess, plan, and control geothermal development (adequate safeguards)

2.23 Capability of schools to absorb new children

2.24 Forest Service leasing policies, procedures, and practices

2.25 Fragmented permitting, regulation and control (ineffective comprehensive area-wide management)

*2.26 Fragmented EIR process (non-comprehensive evaluation)

2.27 Capability of providing services such as fire and police

2.28 Establishment of a municipal geothermal utility

\section{Fiscal}

\subsection{Constraints--Major Concerns}

Fiscal impacts of geothermal development

\subsection{Subsidiary--Secondary Concerns}

3.21 Property tax revenues

3.22 Fees and lease payments to BLM and Forest Service and pass through to county

3.23 In lieu payments by public utility district or other exempt organizations

3.24 Payrol1, sales, and other tax revenues

3.25 Proposition 13, Serrano, SB 90, AB 65, and other uncertainties

3.26 Costs of services provided by public organizations including fire, police, road maintenance, solid waste, health, schools, and administration (EIR's, monitoring) 


\subsection{Subsidiary (cont.)}

3.27 Costs related to construction workers becoming welfare burdens

3.28 Loss in revenues from hunting and fishing licenses, sales tax, and other income (if recreation/tourism is negatively impacted)

4. Land Use

\subsection{Constraints--Major Concerns}

Change in value or utilization of land resources due to geothermal development

\subsection{Subsidiary--Secondary Concerns}

4.21 Change in basic land use values of the area (recreation)

4.22 Preclusion of other uses--short or long run ( 1 and as a resource for future generations)

4.23 Opening of areas through provision of access roads

\section{Economic--Private Sector}

\subsection{Constraints--Major Concerns}

*5.11 Economic viability of geothermal development

5.12 Change in economic character of the area in regard to its recreation and tourism base

\subsection{Subsidiary--Secondary Concerns}

5.21 Construction, operation, and maintenance employment

5.22 Secondary employment

5.23 Change in structure of labor force (skills needed vs. skills in labor force)

5.24 Duration of employment

5.25 Visual, aesthetic pollution (scenic quality)

5.26 Noise during exploration, development, construction, operation, and redevelopment/replacement and its effect on recreation and tourism 


\subsection{Subsidiary (cont.)}

5.27 Degredation/contamination of surface and ground water supplies by seepage, spills, runoff, and condensate and effect on wildife habitat, vegetation, aquatic life and resultant economic impact

5.28 Non-condensable gas effects

5.29 Surface disturbance (dust,...)

5.210 Change in flow or character of water for Hot Creek operations including hatchery and baths

5.211 Additional roadways and other access

5.212 Favorable utility pricing and encouraging of additional recreation-based development

5.213 Noise, water characteristics and availability, dust, and gas effects on livestock operations

5.214 (Same as 5.213) on agricultural crops including forage

5.215 Removal of timber for exploration and construction

5.216 Development of geological and mineral data for mineral production

5.217 Demand for sand and gravel

5.218 Stimulation of commercial development

5.219 Stimulation of industrial development

5.220 Product pricing and reliability for domestic as well as business users

5.221 Secondary use of fluids for agriculture before reinjection

*5.222 Cooling water (for production of electric power) availability and allocation

5.233 Loss of revenues by existing LPG and/or electric power suppliers

*5.224 Economic dependence: boom/bust (disruption of economy when supply is depleted)

The issues enumerated above were developed through public participation in our workshop held in Mammoth Lakes (indicated by an asterisk) and through discussions with key local citizens. The issues considered to be most significant are the following: 
1. Project feasibility

2. Impact of geothermal development on the quality and character of life--long as well as short run

3. Impact of geothermal development on the recreation/tourism economic base of the area

4. Fiscal impacts of geothermal development

5. Water quality and quantity including potential conflicts over use and availability.

6. Land use impacts of geothermal development

7. Forest Service policies and practice

As previously stated, so few data are available as to reservoir and plant characteristics, that it is very hazardous to speculate as to possible effects of various alternatives on the socioeconomic environment of the area. For example, a key question is to what degree would development affect the beauty of the area which is so attractive to the recreationist $\pi$ Another,--would product economics and reliability be such as to provide economic stimulus $\pi$

It would appear reasonable to assume that overall socioeconomic effects would be greatest during the construction phases of any facilities and for alternative three (more than 100 MWe capacity, generating power for export). The social character of the area will probably not change significantly unless a very substantial alternative three is the case. Once construction is complete, even if all the operations families are new to the area, 40 to 60 people will hardly change the demographics. On the other hand, there are those who will argue that even a small heating plant located over the horizon will have some impact on that intangible quality of life fabric. There is no question that locating an industrial plant in an area of pristine natural beauty, however underutilized now, will have some impact in the minds of the beholders. It will be important to identify the criteria with which to assess this factor if development takes place.

Some impact, depending on the alternative scale of construction, will occur on housing. The impact should be negligible subsequently. Some secondary impact on the housing market is possible if product costing and reliability are favorable.

If development proceeds, the county will adapt to the needs for ordinances and other administrative requirements. If a municipal utility-type district is selected, this will have an effect on local control. Schools may be impacted during construction, particularly if construction workers' children are non-English speaking or have other special needs. Fiscal effects would be significant, particularly if an alternative three-type facility is constructed. This will be true on both the revenue and the expenditure sides of the ledger. As with schools, it must be remembered that the base numbers of people and dollars are small, therefore it does not take much in the way of new children or dollars to be significant. Of major consequence are the potential constraining impacts of recent legislation, including Proposition 13. 
It is not likely that any primary effects on land use will spill over beyond the area utilized for exploration and construction. Again, if the scale of development is quite large and if the economics are such as to provide products at favorable rates, some effect on land value and utilization may accrue. It will be argued that even though land required for utility development is limited, that such use will preclude good overall future land planning. As to transportation use, some new roads into remote areas would result and some increase in highway traffic and inconvenience during construction would occur.

Employment effects would, of course, be a stimulus during construction, and to some extent subsequently. Other than during construction, the operation, maintenance, and well redevelopment and construction requirements would be low due to low labor-intensity. Large scale development secondary effects are uncertain.

As noted above, some aesthetic effects are inevitable. Impacts depend on factors including siting, scale, and design. The resultant effect on the recreation-tourism industry is unknown. Localized minor impacts on forage and wildlife habitat would occur resulting in the immediately affected areas becoming less attractive to the recreationist and the farmer.

Mining and timber economic activities should not be impacted, except for construction requirements for sand and gravel.

Assuming favorable project economics, but limited effective reservoir life, a replacement strategy would be required.

Concern exists as to a possible change from a recreation and tourism based economy to one supported by other industries. It is not clear even with the alternative three power development that this is probable. While a good utility supply and pricing structure would be a stimulus, it is doubtful that the required skilled labor, transportation, and political support would be available as required for development of alternative industry in the area.

Existing bottled gas and electric suppliers would, of course, be impacted by development of geothermal based alternatives. Any adverse impact on the quality or quantity of water for export to the Los Angeles area would be of great concern to the City of Los Angeles Department of Water and Power. Water allocation for cooling purposes, if required by plant design, would probably be a major issue,--and there is no fight like a water fight.

\subsection{Existing Data}

Known existing data sources which may help in resolution of concerns are listed with reference to the previously enumerated issues and effects. 
Issue/Effect Number

1. Social/Demographic

1.11 Character and quality. life change

\subsection{Social equity}

\subsection{Population Change}

1.212 Employment change

1.213 Age, sex, ethnic change

1.214 Skills change

1.215 Turnover change

1.22 Housing demand, supply, pricing change
ICPOA, Survey of Attitudes

ERA, Econ. Base and Future Outlook..., 1974

MAC, Survey of Attitudes

MPA, Enviro-Background Reports, 1973

FS, Draft Enviro-Statement, Mammoth Mono Planning Unit, 1978

1970 Census

CDF, 1972 Census

ERA, Econ. Base and Future Outlook... 1974

UCLA, Facing the Future, 1972

CEDD, Unpublished survey, Inyo Mono Counties, 1976b

CDF, Provisional Household Projections, 1977

CDF, Population Projections..., 1977

FS, Draft Environmental Statement...., 1978

MPA, Environmental Background Reports, 1973

ERA, Econ. Base and Future Outlook... 1974

CSA, Calif. Co. Fact Books, n.d.

1970 Census

CEDD, 1976 Employment and Payrol1s, 1977

MPA, Draft Environmental Statement..., 1975

CEDD, Labor Market Bulletin, n.d.

1970 Census

CDF, Population Projections..., 1977

CDF, Statistical Abstract, 1976

CDF, 1972 Census

1970 Census

ERA, Econ. Base and Future Outlook..., 1974

CDF, Provisional Household Projections ..., 1977 
UCLA, Facing the Future, 1972

SWA, Monoplan IV, 1975

1.23 Recreation v. geothermal tradeoff

1.24 Exportation

2. Infrastructure

2.11 Government capability

2.21 Local control

2.23 School capacity

- 2.24 Fragmentation of government

2.25 Fragmented EIR

2.26 Service capacity

2.27 Municipal district

3. Fiscal

3.21 Property tax

3.22 Federal fees

3.23 In lieu payments
CDFG, Calif. Fish Wildlife Plan 1965 ERA, Econ. Base and Future Outlook... 1974

MPA, Enviro. Background Reports, 1973 FS, Draft Environmental Statement 1978

OCA, Mammoth Mountain Winter Recreation.... 1978

Haven, The 1972 Flow of Elect. Energy ..., 1976

FS, Unpubl ished Draft EIS, 1977

Sims and Racine, Feasibility..., 1977

CERCDC, Biennial Report, 1977

Fredrickson, Analysis of Requirements ..., 1977

BLM, BLM Regulations.

CCO, Annual Reports Fin. Transactions....

MCSS, ADA statistics

Cal. Pub. Resource Code

Cal. Admin. Code

Geothermal Steam Act

Geothermal Resources Operation Orders, et al.

Fredrickson, Analysis of Requirements ..., 1977

CCO, Annual Reports Fin. Transactions...

Mono Co. Final Budget, 1977-78

Calif., State of Calif. Traditional Detail...

FS, Draft Environmental Statement, 1978 
3.24 other revenues

3.27 Welfare costs

3.28 Revenue losses

4. Land Use

4.21 Value change 4.22 Alternative use
constraints

4.23 Opening of new areas

5. Economic - Private Sector

5.11 Project viability

5.12 Area economic change
FS, Draft Environmental Statement, 1978

SWR, Draft Enviro. Statement..., 1975

CSBE, Trade Outlets and Taxable Retail Sales...

CSBE, Taxable Sales in Calif. During 1976,1978

Mono Co. Final Budget, 1977-1978

See above

UCLA, Facing the Future, 1972

MCWD, Unpublished reports

1970 Census

ERA, Economic Base and Future Outlook ..., 1974

SWR, Draft Env. Statement..., 1975

UCLA, Facing the Future, 1972

MPA, Enviro. Background Reports, 1973

SWA, Monoplan Phase IV, 1975

MCPBD, General Plan, Ordinances....

Sims and Racine, Feasibility of Geothermal Space/Water Heating, 1977

Sims and Racine, Additional Studies... 1978

Fredrickson, Analysis of Requirements, 1977

Larson, Economic Reasibility..., 1978a

Larson, Effects of Tax Incentives, 1978b

Racine, Economics of Geothermal Space/ Water Heating, 1978

Ramachandrau, Economic Analysis of Geothermal..., 1977

Barrager, Econ. Anal. of Geothermal ..., 1977

Larson, The Costs of Geothermal

Energy..., 1977

MPA, Enviro. Background Reports, 1973 


\subsection{Employment - primary}

5.22 Secondary employment

5.23 Change in labor force structure

5.24 Duration of employment

5.25 Visual and aesthetic pollution

\subsection{Noise}

5.27 Water degradation

5.28. Non-condensable gases

5.29 Surface disturbances

5.210 Hot Creek

5.211 New road access

5.212 Product pricing for additional recreation

5.213 Livestock

5.214 Agricultural crops

5.215 Timber

5.216 Data for mineral production

5.217 Sand and gravel

5.218 Stimulation commercial development
ERA, Economic Base and Future Outlook ..., 1974

PGE, Geysers Units 16 a 17 NOIS

See 1.212

See 1.212

See 5.11

FS, Draft Enviro. Statement, Mammoth Mono Planning Unit, 1978

EPA, Guidelines to Water Quality Management...., 1971

CDWR Recon. Investigation of Water Resources..., 1960

CDWR, Hydrologic data....1975, 1977

Sorey, Potential Effects of Geothermal Development on Springs..., 1976

FS, Draft Enviro. Statement Mammoth Mono Planning Unit, 1978

MPA, Enviro. Background and Reports, 1973

CDF, Calif. Statistical Abstracts

CDF, Calif. Statistical Abstracts IMCAC, Annual Crop Livestock Reports

FS, Draft Enviro. Statement, 1978 
5.219 Stimulation industrial development

5.220 Product pricing for domestic $\alpha$ business use

See 5.11

5.221 Secondary use

5.222 Water use conflicts

UCLA, Facing the Future, 1972

5.223 Existing suppliers

LADWP, EIR Increasing Pumping, 1978 revenue losses

5.224 Boom or bust

Abbreviations

$\begin{array}{ll}\text { BLM } & \text { Bureau of Land Management } \\ \text { CCO } & \text { California Controllers Office } \\ \text { CDF } & \text { California Department of Finance } \\ \text { CDFG } & \text { California Department of Fish and Game } \\ \text { CDWR } & \text { California Department of Water Resources } \\ \text { CEDD } & \text { California Employment Development Department } \\ \text { CERCDC } & \text { California Energy Resources Conservation and Development } \\ & \text { Commission } \\ \text { CSA } & \text { County Supervisors Association } \\ \text { CSBE } & \text { California State Board of Equilization } \\ \text { EPA } & \text { Environmental Protection Agency } \\ \text { ERA } & \text { Economic Research Associates } \\ \text { FS } & \text { USDA - Forest Service } \\ \text { ICPOA } & \text { Inyo County Property Owners Association } \\ \text { IMCAC } & \text { Inyo-Mono Counties Agricultural Commi ssioner } \\ \text { LADWP } & \text { Los Angeles Department of Water and Power } \\ \text { MAC } & \text { Mammoth Advi sory Council } \\ \text { MCPBD } & \text { Mono County Planning and Building Department } \\ \text { MCSS } & \text { Mono County Superintendent of Schools } \\ \text { MCWD } & \text { Mono County Welfare Department } \\ \text { MPA } & \text { Monoplan Associates } \\ \text { OCA } & \text { O'Connor and Associates, and Wallace, McHarg, Roberts and Todd } \\ \text { PGE } & \text { Pacific Gas and Electric } \\ \text { SWA } & \text { The SWA Group, formerly Sasaki, Walker, Roberts Associates } \\ \text { SWR } & \text { Sasaki, Walker, Roberts Associates } \\ \text { UCLA } & \text { University of California, Los Angeles }\end{array}$

Many of the available data for characterization of the Mono-Long Valley area are derived from the 1970 census. These data have been supplemented through the use of a number of studies made during the early 1970's focusing particularly on the Mammoth Lakes portion of the area. Quality and quantity of this information typically vary. Using this base one may characterize the area, however, inadequate data are available for assessment of potential project impacts. 
The fundamental data problem is the paucity of reservoir information with the attendant lack of plant data. Except for the heating alternative, data are essentially unavailable on plant, transmission, and product and related economics. Demand for electric power and heating products is consequently unclear. Given these and related data gaps, it is not surprising that reliable information concerning public attitudes toward geothermal development is quite limited.

\subsection{Data Requirements}

The basic data requirement then is for data with which to characterize the geothermal reservoir. Secondly, scenario-type information is needed. This includes plant type, size, location, timing, cost, feasibility, manpower, transmission and water requirements. Third, product pricing, rellability and demand data are required.

Updated demographic information reflecting the entire area, not only Mammoth Village, is needed. Data regarding permanent residents and also the very significant seasonal population should be gathered. An inventory of skills in the employment base would be helpful. Information concerning related governmental policies, procedures, practices, and interactions between agencies is required.

Data reflecting the attitude of the general public toward geothermal development based on development scenarios would be of great importance.

\subsection{Recommendations}

As previously called for, a fundamental need is for testing and characterization of the geothermal resource. It is suggested that this be followed by the development of alternative scenarios. These should deal with both the district heating and electric power options as well as appropriate facilities designed for local consumption and for export. As this information is made available, it is recommended that studies proceed stepwise to provide data for addressing issues, concerns, and needs. Suggested studies and projects include the following:

1. Updated economic and social baseline

Obtain, assess, and monitor pertinent data for the entire area including sectors other than Mammoth Lakes

2. Alternative development feasibility analysis

Prepare cost, price, and demand studies for alternative geothermal schemes; overall project feasibility analyses 
3. Recreation and tourism impact study

Evaluate short and long run impacts of alternative geothermal developments on recreational use and the attendant economic vitality of the area; potential impacts to be given special attention should include land use and value, Hot Creek uses, and employment

4. Fiscal impact

Determine governmental costs and revenues associated directly andindirectly with alternative development scenarios

5. Water

Study cooling water requirements and availability for electric power generation

6. Institutional

Assess U.S. Forest Service and county government policies, regulations, and practices regarding geothermal and related developments; governmental agency interactions and alternatives for optimizing interactive management; public versus private utility ownership

7. Public participation and attitudes

Develop through the leadership of a local organiza$t i o n$ such as Inyo-Mono Association of Governmental Entities (IMAGE) requisite knowledge as to alternative developments and their effects, as well as processes, regulations, and safeguards found effective by others. Through such an organization, assessments of leadership and general public attitudes should be carried out. Additionally mutually acceptable criteria might be developed for assessment of project acceptability. 


\section{ACKNOWLEDGMENTS}

The following people participated in the socioeconomic discussions at the workshop in Marmoth Lakes, August 10-11, 1978: Grace Enfield, Charles Fredrickson, James Griswold, Andrea Lawrence, David Layton, Lowell Miller, W. Craig Racine, Doug Sherburne, and Carolyn Trindle. Affiliations are given in Appendix IV to the report.

The following reviewers comented on draft versions of this report: Barry $A$ Boudreau and associates (U.S. Geological Survey, Menlo Park), C. D. Fredrickson, A. Lawrence, D. Layton, 0. R. Lunt (UCLA Laboratory of Nuclear Medicine and Radiation Biology), Susan Marquez (UCLA, LNMRB), W. C. Racine, Robert W. Sandy (Mono County Planning Director), C. Strojan, Joy Thornbury (UCLA, LNMRB), James F. Wickser, and S. Y. Willard. 
Barrager, S. M. and D. J. Quinn. 1977. Economic Analyses of Geo thermal Energy Development in California. Menlo Park, Calif.: Stanford Research Institute.

California. 1978. Governor's Budget for FY 1978-1979. Sacramento, Calif.

California. 1969. State of California Traditional Detail for the Support and Local Assistance Budget for the Fiscal Year July 1, 1969 to June 30, 1970. Submitted by Ronald Reagan, Governor, to the California Legislature. Sacramento, Calif.

California Controllers Office. 1967-1977. Annual Reports of Financial Transactions Concerning School Districts of California. Sacramento, Calif.

California Department of Finance. 1967-1977. Annual Reports of Financial Transactions Concerning Counties of California. Sacramento, Calif.

California Department of Finance. 1977a. California Statistical Abstracts. Sacramento, Calif.

California Department of Finance. 1972. 1972 Special Census, Special Enumeration.

California Department of Finance. Population Research Unit. 1977b. Population Projections for California Counties 1975-2020 with Age/Sex Detail to 2000. : Series D-150. Sacramento, Calif.

California Department of Finance. Population Research Unit. September 15, 1971. Provisional Projections of California Counties to 2000. Sacramento, Calif.

California Department of Finance. Population Research Unit. 1977c Provisional Household Projections of California Counties to 2000. Report 77; P-2. Sacramento, Calif.

California Department of Fish and Game. 1965. California Fish and Wildlife Plan.

California Department of Water Resources. 1977. Hydrologic Data: 1975. Bulletin No. 130-75, Vol. V: Southern California.

California Department of Water Resources, Southern District. 1960. Reconnaissance Investigation of Water Resources of Mono and Owens Basins, Mono and Inyo Counties. Prepared pursuant to Senate resolution No. 59, Legislative session of 1964.

California Employment Development Department. n.d. Labor Market Bulletin.

California Employment Development Department. 1975. Southern California Employment Data and Research. 
California Employment Development Department. 1977. 1976 Employment and Payrolls. Report 127. Sacramento, Calif.

California Employment Development Department. 1976. Unpublished Survey, Inyo-Mono Counties.

California Energy Resources Conservation and Development Commission. 1977. Biennial Report of the State Energy Cormission. Vol.2. Electricity Forecasting and Planning. Sacramento, Calif.

California State Board of Equilization. Taxable Sales in California (Sales and Use Tax During 1976). Sixteenth Annual Report. Sacramento, Calif.

California State Board of Equalization. Trade Outlets and Taxable Retail Sales in California During 1965. Sixth Annual Report. Sacramento, Calif.

California State Board of Equalization. Taxable Sales in California (Sales and Use Tax During 1977). 1st quarter, 2nd quarter, 3rd quarter, 4th quarter. Sacramento, Calif.

California State Board of Equalization. Trade Outlets and Taxable Retail Sales in California During 1970. Tenth Annual Report. Sacramento, Calif.

California State Lands Comission. 1977. Public Land Ownership in California, Sacramento, Calif.

Economic Research Associates. 1974. Economic Base and Future Outlook Study for the IMAGE planning area. Prepared for Inyo Mono Association of Governmental Entities. Los Angeles: Economic Research Associates.

Environmental Protection Agency. 1971. Guidelines to Water Quality Management.

Fredrickson, C.D. 1977. Analysis of Requirements for Accelerating the Development of Geothermal Energy in California. JPL Publication 77-63. Pasadena: Jet Propulsion Laboratory, California Institute of Technology.

Haven, K. F. 1976. The 1972 Flow of Electrical Energy in California and its Relationship to Selected County Level Characteristic Parameters. Livermore, Calif.: Lawrence Livermore Laboratories.

Inyo County Property Owners Association. 1978. Opinion Survey.

Inyo-Mono Counties Agricultural Commissioner. Annual Crop Livestock Reports.

Larson, T. 1977. Final Report January 1977, The Costs of Geothermal Energy Development. DLRI Report No. 13. Riverside, Calif.: University of Calif., Dry Lands Research Institute.

Larson, T. C. 1978a. Economic Feasibility Model for Direct Heat Applications of Geothermal Energy. La Jolla, Calif.: Science Applications, Inc. 
Larson, T. C. 1978b. Effects of Tax Incentives on Geothermal Development. La Jolla, Calif.: Science Applications, Inc.

Los Angeles Department of Water and Power. 1978. EIR on Increased Pumping of the Owens Valley Groundwater Basin.

Marmoth Advisory Council. Survey of Attitudes.

Mammoth Mountain Ski Area, Personnel Office. November 1978. Telephone Conversation.

Mono County Final Budget for FY 1977-1978. Compiled in the office of M.K. Schlaegel, Auditor-Controller.

Mono County Planning Director. 1978. Interview.

Mono County Superintendent of Schools. 1978. Interview.

Mono County Welfare Department. Unpublished Reports.

Monoplan Associates. 1973. Monoplan Phase 2: Environmental Background Reports. South Pasadena, Calif.: Monoplan Associates.

Monoplan Associates. 1975. Draft Environmental Statement for Monoplan for Mammoth. Sausalito, Calif.

0'Connor and Associates, and Wallace McHarg, Roberts and Todd. 1978. Mammoth Mountain Winter Recreation Masterplan Alternatives. Mammoth Lakes, Calif.

0liphant, R. September 1978. California Department of Education. Telephone conversation.

Pacific Gas and Electric.Co. 1978. Geysers Units 16 and 17 Notices of Intent. Submitted to California Energy Resources Conservation and Development Comission.

Racine, W. C. 1978. Economics of Geothermal Space/Water Heating in Mammoth Lakes, California. Direct Utilization of Geothermal Energy: A Symposium. CONF-780133, pp. 57-59. Davis, Calif.: Geothermal Resources Council.

Ramachandrau, G. 1977. Economic Analyses of Geothermal Energy Development in California. Palo Alto, Calif.: The Stanford Research Institute.

Responses to Gallup Poll Favor Protection of Desert. February 16, 1978. Inyo Register. Bishop, Calif.

Ripley, M. Analyst for the California State Employment Development Department. September 1978. Telephone conversation.

Rose, A. 1977. The Economic Impact of Geothermal Energy Development. Riverside, Calif.: University of Cal ifornia. 


\title{
Chapter 9
}

ARCHAEOLOGICAL AND CULTURAL RESOURCES OVERVIEW

\author{
Carl L. Strojan \\ Laboratory of Nuclear Medicine and Radiation Biology \\ University of California, Los Angeles
}


TABLE OF CONTENTS

INTRODUCTION .............................. 257

EXISTING DATA BASE ............................ 257

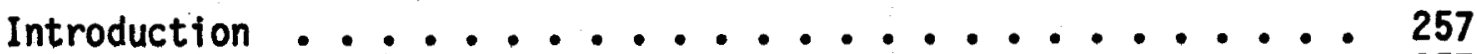

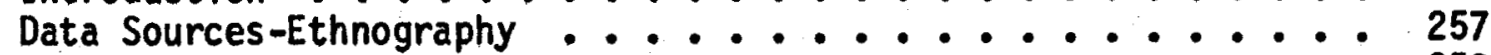

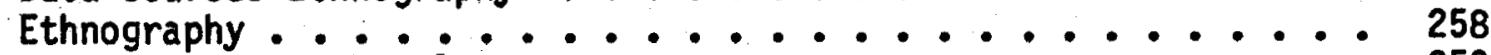

Data Sources-Archaeology .................... 259

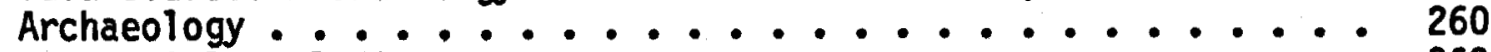

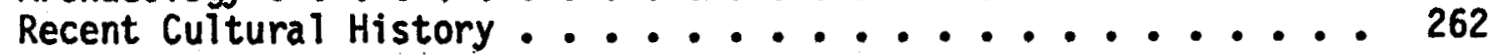

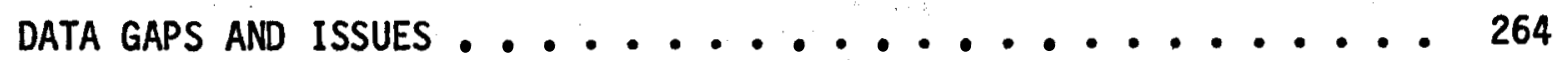

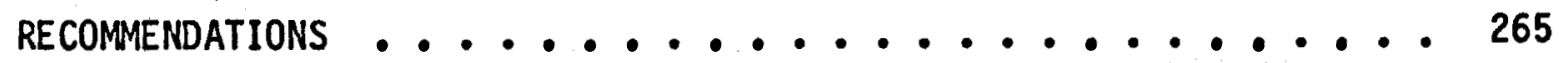

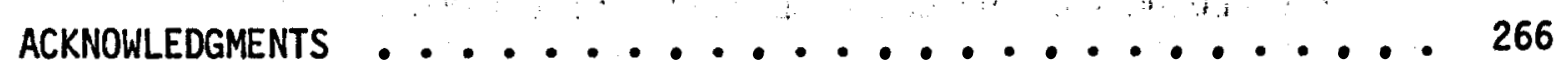

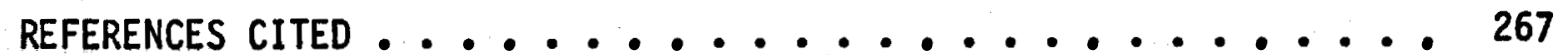

\section{LIST OF TABLES}

1. Characteristics of Major Archaeological Site

Categories in Long Valley ................ 261

2. Distribution of Archaeological Site Categories

by Biotic Community in Long Valley............. 262

3. KGRA Sites Being Considered for Inclusion in the National Register of Historic Places ............ 


\section{INTRODUCTION}

The Assistant Secretary for Environment does not have responsibility for archaeological or cultural issues in the U.S. Department of Energy. Nevertheless we are including an archaeological overview in our report because of the long cultural history of the Mono-Long Valley region, strong interest shown by both professional and amateur archaeologists, and because archaeological and cultural resources are afforded protection by law. For example, the National Historic Preservation Act of 1966, the National Environmental Pol icy Act of 1969. Executive Order 11593 "Protection and Enhancement of the Cultural Environment,": the Archaeological and Historical Preservation Act of 1974, and the American Indian Religious Freedom Act of 1978 are applicable to projects on federal lands.

The aims of this chapter are to summarize the existing archaeological and cultural data base for Mono-Long Valley KGRA, to identify and assess key archaeological-cultural issues and data gaps relating to geothermal development, and to set forth recomendations which may help to resolve key issues. The identification of issues and recommendations occurred as part of our workshop in Mammoth Lakes on August 10-11, 1978. It is perhaps worth noting that the archaeology group had the largest attendance and liveliest discussion of any of the workshop sessions.

\section{EXISTING DATA BASE}

\section{Introduction}

The entry of white men into the Mono-Long Valley region is believed to have first occurred around 1825 when Jedediah Smith and a party of trappers passed through the area (Chalfant 1922, p. 42). Prior to that time the region was inhabited for many centuries by Northern Paiutes and their predecessors. Because of the long history of human occupation in the region and the area's relatively isolated location, numerous archaeological sites are distributed throughout the KGRA. Only in recent years, though, have efforts been made to piece together the archaeology of the region and the ethnography of the people who inhabited it.

\section{Data Sources-Ethnography}

One of the earliest studies is contained in the classic ethnographic report by Steward (1933). Although his study was concerned primarily with Owens Valley, it also considered some more northern areas such as Mono Lake. It was based on two visits of about six weeks each to Owens Valley and Mono Lake during the summers of 1927 and 1928, and a short visit in December 1931 (Steward 1933, p. 233). It considered such diverse topics as tribal distributions, population status and psychology, seasonal occupations, seed gathering and preparation, irrigation, fishing, hunting, domesticated animals, trade and transportation, weapons, houses, pottery, weaving, clothing, miscellaneous arts and industries, musical instruments, songs, games, astronomy, birth and childhood, names, puberty, marriage, death, kinship terms and usages, political organizations, property, warfare, religion, shamans, medicinal plants, dances and mythology. Much of the information in Steward's report came from local informants. 
Three other ethnographic reports of the region are those by Davis (1962, 1963, 1965). Her studies focused on the Northern Paiute of Mono Lake Basin. They were based on field work conducted in 1959 and 1960 in the village of Lee Vining, where about 37 Paiute lived at the time. This work was also complimented by her archaeological investigations in the area. In addition to considering traditional ethnographic topics such as food, clothing, group authority, etc., a strong emphasis was placed on the relationship of the people to their physical and biological environment.

\section{Ethnography}

Based on the above published sources and others given below, it is possible to summarize what is known and postulated about the ethnography of the native inhabitants of the Mono-Long Valley region.

The Northern Paiute of Mono-Long Valley are more closely related by language and culture to the Shoshone of the Great Basin than to the California Indians west of the Sierra Nevada (Smith 1976, p. 129). The early culture of these people has been described as one of seasonal transhumance, namely "...the practice of changing abode in a regular and traditionally recognized way, as natural food crops are followed" (Davis 1963, p. 202). Populations were thus mobile and not confined to permanent villages. According to Davis (1963) this way of life had two important features. First it allowed people to seasonally exploit various food crops as they became available at different altitudes. Secondly, it afforded climatic protection as the people moved to warmer valleys in winter and cooler mountains in sumer.

Seasonal transhumance necessitated a close relationship to the physical and biological world which the people inhabited. This is perhaps best illustrated by considering food gathering practices as described by Steward (1933) and Davis (1962, 1963, 1965). According to Steward (1933, p. 241) pinyon nuts (Pinus monophyllum) were the most important Paiute food, and each district owned pinyon territory. Nut gathering occurred during autumn and abundant crops lasted through the winter and into the summer (Steward 1933, p. 241). Green parts, seeds, roots, tubers and berries of numerous other plants were also utilized. Steward (1933, pp 242-246) identified about sixty different plants and their uses--mainly from informants at Big Pine, Bishop and Mono Lake. Chalfant (1922) also included a list of plants important to local Indians. Agriculture was not practiced but irrigation was used in the Owens Valley to increase the yield of natural vegetation (Chalfant 1922, Steward 1933, p. 247). Animals of various kinds were also utilized as food, including rabbits, rodents, deer, mountain sheep, birds, and fish--although apparently the only place where native fish occurred was in the Owens River. Hunting occurred individually or in small groups.

The pupae of the brine fly, Ephydra hians, were an important and somewhat unique source of food for the Mono Lake Paiute. In fact these people were known as the Kuzedika or fly-pupae eaters (Aldrich 1912; Davis 1962, 1963, 1965). Enormous numbers of pupae washed ashore during late summer where they drifted into windrows and were collected. They were then dried, the puparia were rubbed off by hand, and the remaining pupae used for food (Aldrich 1912, p. 90). 
Caterpillars of the Pandora moth (Coloradia pandora) were another important and somewhat unique source of food for the Mono Lake Paiute (Aldrich 1921). The life cycle of the moth took place in the extensive Jeffrey pine forests to the south of Mono Lake. It lasted two years, so that caterpillars were collected only in alternate years. A description of the life history of the moth is given by Aldrich (1921). As caterpillars descended the Jeffrey pine trees to pupate in the ground, they were trapped in trenches dug around individual trees, collected, and preserved by killing and drying in hot ashes.

Dwellings, other structures and tools also indicate the transhumance way of life of the Northern Paiute. Dwellings were apparently simple structures built of poles, brush and grass (Steward 1933, Davis 1965). Consequently, there is little evidence of these structures remaining at archaeological sites. The Kuzedika of Mono Lake had only stone tools and a crude brown-ware pottery which was occasionally used (Davis 1962). Metates and manos and bedrock mortars are examples of tools which have been found at various locations in the KGRA. These and other durable remains, such as projectile points, stone rings, rock shelters, and petroglyphs comprise most of the archaeological resources in the KGRA.

\section{Data Sources-Archaeology}

The foregoing discussion of the ethnography of the early native inhabitants is important in understanding the archaeology of the region. The earliest professional archaeological data from Mono County were obtained from a survey by Meighan (1955). It consisted of one month of field work in August 1953 by a crew of four people from the University of California, Los Angeles. "Five selected areas were examined, two of which were located in the present-day KGRA. The KGRA sites were at Crooked Meadow and on the Owens River just north of Crowley Lake. A total of 315 archaeological sites were identified in these five areas, 18 of which were in the KGRA. Brief descriptions were given of the areas surveyed and artifacts which were collected.

A short report by Davis (1961) discussed the presence and possible significance of a group of petroglyphs near Mono Craters. Neither their age nor significance could be determined from living Paiutes. Enfield and Enfield (1964) reported the results of an archaeological excavation in Mammoth Creek Cave. The excavation was a joint project undertaken by the U.S. Forest Service and the Eastern California Museum. The report contains a good review of prior archaeological work in the area, as well as results of their own excavations. Original data include details of the excavation and descriptions of artifacts which were found in the cave.

A major report on the archaeology of Mono Bas in and Hot Creek was presented by Davis (1964). The report is based on a two-week survey of 165 sites in Mono Basin, a limited excavation of two rock shelters at Hot Creek, and data derived from existing sources. Eight types of sites were identified and described, each based on use and seasonal occupancy. Detailed descriptions of artifacts were also given, some of which came from private collections.

The major archaeological data source for Long Valley is a report of a thirtylay study of Bettinger (1977). The study was a cooperative effort between the University of California, Riverside and the U.S. Forest Service in an area 
roughly corresponding to the so-called "grandfather lands" in Long Valley currently being considered for geothermal leasing. : The report is one of the few archaeological studies in the area to follow an identified research design. The design was based on three assumptions: (1) that resources critical to the aboriginal adaptation were unevenly distributed over the landscape, (2) that precise quantitative estimates of the archaeological resources within each biotic comunity (sagebrush, Jeffrey pine, pinyonjuniper) could be obtained by some means of probability sampling, and (3) that the function of archaeological sites encountered in the survey could be determined on the basis of their surface assemblages (Bettinger 1977). Included in the report are the research design, survey results, a discussion of aboriginal land use patterns, and recommendations for management of archaeological resources in the area.

The Native American Heritage Commission is a state agency created in 1976 which is responsible for identifying places of special religious or social significance to Native Americans, and for making recommendations to the legislature concerning their protection.

The State Office of Historic Preservation administers several programs related to cultural resources, including the National Register of Historic Places, the California Historical Landmarks Program, and the Historic Points of Interest Program (Henry Bass, personal communication). The Office is also responsible for reviewing federal projects to ensure compliance with legal statutes protecting cultural resources.

The Archaeological Research Unit of the Dry Lands Research Institute, University of California, Riverside maintains archaeological site survey records for Mono, Inyo and Riverside counties. Site records are also identified on U.S. Geological Survey topographical maps. Some reports are on file, but the completeness of the files and survey records is dependent upon investigators sending materials to the Research Unit.

The U.S. Forest Service and Bureau of Land Management are required by law to do an archaeological reconnaissance for projects which will involve surface disturbance, e.g. road building, timber removal, campground construction, etc. These reports can be obtained from the federal agencies or the Archaeological Research Unit at the University of California, Riverside.

\section{Archaeology}

Steward (1933, p. 237) estimated the early Paiute population of the Owens Valley region at about 1000 people, while Bettinger (1977, p. 56) suggested that Long Valley Caldera probably sustained no more than ten people, or about two families. However, as Davis (1963) pointed out, the large number of archaeological sites in the area can convey a deceptive impression of high population density. The work by Bettinger (1977, p. 42) indicated that archaeological site density could be as high as 51 per square mile in pinyonjuniper habitats. The high archaeological site density in spite of apparent low population density can be explained by several factors. One is the transhumance type of life discussed earlier, with seasonal migrations involving temporary camps, storage sites, and use areas. Another factor is that Mono-Long Valley was the site of several trade routes across the Sierra Nevada (Steward 1933, p. 257; Davis 1965, p. 21) and Glass Mountain was a major site 
for obsidian collection (Steward 1933, p.262). Obsidian, pinenuts and other goods were traded to the Western Mono and Miwok Indians in exchange for shell money, baskets and other goods (Steward 1933, p. 257). A third factor resulting in the relatively high density of archaeological sites is the long history of human occupation in the area. Bettinger (1977, p, 44) found evidence of human occupation in Long Valley Caldera for almost 6,000 years.

Archaeological sites and artifacts provide much of the extant information about the existence of early Indians. Davis (1964) described eight types of archaeological sites: summer base camps, caterplllar collecting sites, quarry and/or workshop sites, travellers' and hunters' sites, spring camps, and winter camps. Bettinger (1977) used a number of varlables to classify areas as occupation sites, pinyon camps, temporary camps, or quarries (Table 1).

Table 1

CHARACTERISTICS OF MAJOR ARCHAEOLOGICAL SITE CATEGORIES IN LONG VALLEYa

\begin{tabular}{|c|c|c|c|c|c|}
\hline & $\begin{array}{c}\text { Occupation } \\
\text { Site } \\
\end{array}$ & $\begin{array}{l}\text { Pinyon } \\
\text { Camps } \\
\end{array}$ & $\begin{array}{c}\text { Temporary } \\
\text { Camps } \\
\end{array}$ & Quarries & OVERALL \\
\hline No. in Category & 1 & 4 & 41 & 15 & 61 \\
\hline Rock Rings & 0.11 & 1.00 & 0.00 & 0.00 & 0.00 \\
\hline Millingstones & 1.00 & 0.50 & 0.00 & 0.07 & 0.07 \\
\hline Mortars & 0.00 & 0.25 & 0.00 & 0.07 & 0.03 \\
\hline Manos & 0.00 & 0.50 & 0.15 & 0.00 & 0.13 \\
\hline Proj. Points & 0.00 & 0.50 & 0.10 & 0.20 & 0.17 \\
\hline Bifaces & 1.00 & 0.50 & 0.10 & 0.20 & 0.17 \\
\hline Roughouts & 1.00 & 0.00 & 0.20 & 0.13 & 0.18 \\
\hline Unifaces & 0.00 & 0.25 & 0.12 & 0.07 & 0.12 \\
\hline Cores & 1.00 & 0.50 & 0.15 & 0.53 & 0.23 \\
\hline Lt. Debitage & 0.00 & 0.25 & 0.59 & 0.13 & 0.48 \\
\hline Med. Debitage & 1.00 & 0.25 & 0.20 & 0.35 & 0.25 \\
\hline Hvy. Debitage & 0.00 & 0.00 & 0.20 & 0.53 & 0.28 \\
\hline$x$ Area $\left(m^{2}\right)$ & 15,750 & 1684 & 1420 & 28,773 & 8399 \\
\hline
\end{tabular}

avalues indicate the frequency with which archaeological categories occur at sites in that category as determined by $n / N$, where $n=$ number of sites where the category is present and $N=$ number of sites in the category.

Source: Bettinger (1977) 
As is indicated in Table 1, temporary camps were the most abundant, and occupation sites the least abundant. Characteristics of the temporary sites were quite variable because of their apparent use for a variety of purposes such as hunting, obsidian collection, plant gathering, etc. Types of artifacts and the frequency with which they were found in the various sites are also shown in Table 1. Rock rings were interpreted as the remains of pinyon storage pits or house foundations; millingstones were surfaces used for seed processing; mortars were conical pits used for crushing and pounding food; projectile points were dart or arrow tips; bifaces were bifacially flaked knives larger than projectile points; roughouts were bifacially flaked pieces lacking suitable cutting edges; unifaces had at least one unifaciallyflaked edge; cores were large pieces of stone from which useable flakes were struck; and debitage included all waste chippage (Bettinger 1977, p. 17).

The relative distribution of site categories in Long Valley Caldera is shown in Table 2. It should be pointed out, however, that these were identified from sample tracts in an area of about 30,000 acres. Only about $7 \%$ of the 30,000 acres was actually surveyed. Statistical analyses of the sampling data indicated that site density in the sagebrush community of Long Valley Caldera would vary from about 5 to 20 sites per square mile; and density in the pinyon-juniper community would vary from about 19 to 51 per square mile (Bettinger 1977, p.42).

TABLE 2

DISTRIBUTION OF ARCHAEOLOGICAL SITE CATEGORIES BY BIOTIC COMMUNITY IN LONG VALLEY

\begin{tabular}{|c|c|c|c|c|c|c|}
\hline Community & $\begin{array}{l}\text { Occupation } \\
\text { Sites } \\
\end{array}$ & $\begin{array}{l}\text { Pinyon } \\
\text { Camps } \\
\end{array}$ & $\begin{array}{c}\text { Temporary } \\
\text { Camps } \\
\end{array}$ & Quarries & Total & $\begin{array}{l}\text { No. of } \\
\text { Tracts }\end{array}$ \\
\hline Sagebrush & 1 & 0 & 18 & 0 & 19 & 23 \\
\hline $\begin{array}{l}\text { Jeffrey } \\
\text { Pine }\end{array}$ & 0 & 1 & 6 & 15 & 22 & 18 \\
\hline $\begin{array}{l}\text { Pinyon- } \\
\text { Juniper }\end{array}$ & 0 & 3 & 18 & 1 & 22 & 10 \\
\hline Total & 1 & 4 & 42 & 16 & 63 & 51 \\
\hline
\end{tabular}

Recent Cultural History

Exploration in the Mono-Long Valley region by white men occurred relatively recently, as was mentioned in the introduction. After this initial entry, it was still many years before mining became a major activity in the eastern Sierra and led to a major influx of white men. Leroy Vining and some companions are credited with being the first prospectors east of the Sierra in 1853 
(Smith 1976, p. 133). In the following years, gold and silver were prospected in a number of claims in the KGRA and surrounding area. The portion of Marmoth Lakes Village called 0ld Mammoth takes its name from the Mammoth Mining Company developed by General George Dodge in 1878 (Smith 1976). It was during these years that Mark Twain visited the area and wrote a colorful report of a trip to Mono Lake (Twain 1872). Other descriptions of the mining activities of this period in history are given by Browne (1865), Irelan (1888), Cain (1961) and Brewer (1966). An excellent and more recent history of these times is set forth by Smith (1976). By 1890, most of the mines had closed. Except for some clay, pumice, sand and gravel removal, mining is no longer a major activity in the KGRA. Some of the early mine sites, however, have been proposed for inclusion in the National Register of Historic Sites (U.S. Forest Services 1978). These and other sites being considered for inclusion are shown in Table 3.

Following the decline of mining activities, human population decreased and the local economy was subsequently based on farming and ranching (sheep and cattle). Population remained at low levels until recent growth stimulated by recreation, especially winter sports. The KGRA, and particularly the area around Marmoth Lakes, is now one of the most popular year-round recreation areas in California. More detailed information on this topic is covered in our chapter on socioeconomics.

One final point concerning recent cultural history involves the diversion of surface and ground waters from the KGRA and Owens Valley to supply the City of Los Angeles. Construction of the Los Angeles-Owens River Aqueduct was completed in 1913. In 1940 the aqueduct was extended northward to divert surface waters normally entering Mono Lake. In 1970 a second barrel was added to the aqueduct, so that nearly all surface waters are now diverted from Mono Lake (Los Angeles Department of Water and Power, n.d.) These diversions of surface waters from the KGRA and ground waters from the Owens Valley have generated much controversy which continues to this day:

TABLE 3

KGRA SITES BEING CONSIDERED FOR INCLUSION IN THE NATIONAL REGISTER OF HISTORIC PLACES

Mono Mills

Mammoth City

Mill City

Marmoth Creek Indian Caves

Mammoth Creek Hot Springs

Casa Diablo Hot Springs

Lookout Mountain

Source: U.S. Forest Service (1978) 


\section{DATA GAPS AND ISSUES}

The identification of data gaps, issues, and recommendations was based on discussion at our workshop in Marmoth Lakes on August 10-11, 1978, supplemented by the author's understanding and interpretation of existing data.

Members of the archaeology discussion group found it extremely difficult to agree on the major cultural issues and how to best resolve them. This in itself is one of the major issues confronting successful resolution of archaeological and cultural concerns. If there is no consensus about what the major issues are and how they may be resolved, it will be difficult to implement management decisions which are acceptable to various factions.

The large size of the KGRA ( 460,000 acres), the high density of archaeological sites in the area, and the relatively few detailed studies which have been conducted indicate that major gaps exist with respect to the identification and interpretation of archaeological resources. The amount of area to be covered is a major obstacle to filling this gap. For example, the study by Bettinger (1977) is the major source of archaeological data for Long Valley, yet it was based on detailed sampling of only about $7 \%$ of a study area comprising about 30,000 acres. While the study was obviously not intended to be a complete survey of Long Valley Caldera, more complete identification of cultural resources in the area may be required if future conflicts and legal challenges to geothermal leasing are to be avoided.

Because of the large size of the KGRA, there is a need to identify cultural areas which are particularly sensitive to disturbance, valuable for future research, or in regions with geothermal potential. It should be noted that any geothermal exploration and development will likely be restricted to only certain portions of the KGRA. As earlier chapters have indicated, Long Valley has by far the most potential for development. It is not possible, or perhaps even desirable, to conduct a detailed archaeological survey for an area as large as the entire KGRA. A basic issue involves identifying procedures to assure maximum preservation of cultural resources while allowing for geothermal exploration. The experimental approach and management objectives set forth by Bettinger (1977) may be helpful in determining general areas and specific sites in need of protection and further study. For example, because few of them exist, occupation sites and quarries might warrant more protection than temporary camps. Likewise, Bettinger's approach indicated that pinyonjuniper habitat can be expected to have a higher site density than sagebrush, with Jeffrey pine intermediate.

Many of the archaeological resources which have been identified are of relatively recent origin (hundreds of years old), yet evidence suggests that human occupation has occurred in the KGRA for at least several thousand years. Very little is known about the early cultures which preceded the northern Paiute. One problem hindering study of this topic is that much of the KGRA is covered by volcanic ash, including some deposits of relatively recent origin (see Chapter 3).

The concerns of local Indians with respect to geothermal energy development have not been adequately identified. Some of the historical cultural practices such as pinyon nut gathering, caterpillar collection, and the gathering of herbs and medicinal plants are still carried on by some of the local 
Indians. The use of surface hot springs was also part of this cultural heritage, (Davis 1964, p. 263, Smith 1976, p.20), but these uses have not been specifically documented. Since the National Forest lands of the KGRA are open to multiple-use, conflicts have not arisen, in contrast to Coso Hot Springs which has been closed to all civiltans because of military security. There is concern among local Indians and tribal elders, however, about how geothermal development will affect use of these areas in Mono-Long Valley (Blanche Shippentower, personal communication). For example, geothermal drilling and construction in the 1960's changed the character of the Casa Diablo area, and has been cited as a reason that surface hot springs dried up there (Smith 1976, p. 20-21).

\section{RECOMMENDATIONS}

The following recommendations were developed at our workshop in Mammoth Lakes on August 10-11, 1978. They represent a difficult compromise of numerous conflicting views on how to ensure that cultural resources and heritage values are adequately protected during geothermal exploration and development.

1. Cultural Resource Overview. A cultural resource overview of the entire KGRA should be implemented. The concerns of Native Americans should be identified and their involvement in such an overview encouraged. Many participants thought a cultural overview should be completed before any decision is made regarding geothermal leasing.

2. Resource Identification. Cultural resources and/or sites of archaeological significance should be identified in areas being proposed for geothermal leasing by federal agencies. Again, many participants thought this should be done before a decision is made to lease.

3. Research Areas. Efforts should be made to identify and protect potential archaeologicaT research areas in the KGRA.

4. Priority Areas. Priority locations should be established within potential lease areas so that especially sensitive cultural areas can be afforded greater protection.

5. Legal Compliance. Full compliance should be required with legal provisions to protect, identify, preserve or mitigate any negative effects on cultural resources within lease areas. 


\section{ACKNOWLEDGEMENTS}

Emma Lou Davis (Great Basin Foundation) and Gerald Orlob (University of California, Davis) led the discussions and took notes at the workshop in Mammoth Lakes, August 10-11, 1978. Other participants (based on a sign-up sheet) were Richard Austin (U.S. Forest Service), Tom Balint (U.S. Forest Service), Henry Bass (State Office of Historic Preservation), Tilly Barling (Naval Weapons Center, China Lake), L.R. Beidle, Robert Bettinger (New York University and University of California, Riverside), Rollin Enfield (Great Basin Conference), Mary Farrell (U.S. Forest Service), Nicholas Faust (U.S. Forest Service), Richard Foss (Magma Power Co.) James Johnston (U.S. Forest Service), Clyde Kuhn (California Native American Heritage Commission), Charles McDonald (U.S. Forest Service), 011 ie Sapousek (U.S. Forest Service), William Self (U.S. Forest Service), Lewis Tadlock (Tustin), Marc Trumel (Jet Propulsion Laboratory), Phil Wilkie (University of California, Riverside), Syd Willard (California Energy Comission), and Randy Witters .U.S. Forest Service). Complete affiliations are given in Appendix IV to the report.

Discussions with Henry Bass, Clyde Kuhn, Dan McCarthy (University of California, Riverside), and Edwin Rockwell (U.S. Forest Service) were helpful in identifying existing data.

I thank Robert Bettinger, Emma Lou Davis, and Marty Rosen (UCLA, Archaeological Survey) for reviewing the draft of this report. 
Aldrich, J.M. 1912. The biology of some western species of the dipterous genus Ephydra. J. New Entomol. Soc. 20:77-99.

Aldrich, J.M. 1921. Coloradia pandora, a moth of which the caterpillar is used as a food by the Mono Lake Indians. Entomol. Soc. Amer. Annals $14: 36-39$.

Bettinger, R.L. 1977. The surface archaeology of the Long Valley caldera, Mono County, California.. Monograph No. 1, Archaeological Research Unit, Dry Lands Research Institute, University of California, Riverside, 77 p.

Brewer, W.H. 1966. Up and down California in 1860-1864, 3rd ed. (F.P. Farquhar, ed.). Berkeley, Univ. California Press, 583 p.

Browne, J.R. 1865. A trip to Bodie Bluff and the dead sea of the west. Harper's New Monthly Magazine 31:274-284, 411-419.

Cain, E.M. 1961. The story of early Mono County. San Francisco, Fearon Publishers, $166 \mathrm{p}$.

Chalfant, W.A. 1922. The story of Inyo. Published by the author, 358 p.

Davis, E.L. 1961. Mono Craters petroglyphs, California. American Antiquity $27: 236-239$.

Davis, E.L. 1962. Hunter-gatherers of Mono Lake. Southwest Museum Masterkey $36: 23-38$.

Davis, E.L. 1963. The Desert Culture of the western Great Basin: A lifeway of seasonal transhumance. American Antiquity 29:202-212.

Davis E.L. 1964. An archaeological survey of the Mono Lake Basin and excavations of two rock shelters. Univ. Calif. Archaeol. Survey Annual Report 6:225-353.

Davis, E.L. 1965. An ethnography of the Kuzedika Paiute of Mono Lake, Mono County, California. Univ. Utah Anthro. Papers 75:1-55.

Enfield, R., and G. Enfield. 1964. Mammoth Creek Cave, Mono County, California. Univ. Calif. Archaeol. Survey Annual Report 6:393-424.

Irelan, W., Jr. 1888. Eighth annual report of the state minerologist. California State Mining Bureau, Sacramento.

Los Angeles Department of Water and Power. n.d. Los Angeles water rights in the Mono Basin and the impact of the Department's operations on Mono Lake, 22p. 
Meighan, C.W. 1955. Notes on the archaeology of Mono County, California. Univ. Calif. Archaeol. Survey Report 28:6-28.

Smith, G.S. (ed.). 1976. Marmoth Lakes Sierra, a handbook for roadside and trail, 4th ed. Palo Alto, Calif., Genny Smith Books, 147p.

Steward, J.H. 1933. Ethnography of the Owens Valley Paiute. Univ. Calif. Pubi. in Amer. Archaeol, and Ethnog. 33:233-438.

Twain, M. (S.L. Clemens). 1872. Roughing it. Amer. Pub1. Co. 591 p.

U.S. Forest Service. 1978. Draft environmental statement of land management alternatives for the Mammoth-Mono Planning Unit. 171 p. + 8 App. 
LAND WITHIN THE BOUNDARIES OF MONO-LONG VALLEY KNOWN GEOTHERMAL RESOURCES AREA

\section{Mt. Diablo Merdian}

T. I N., R. 26 E., Secs. 1 through 18, 20 through 29 , and 32 through 36 .

T. 2 N., R. 26 E., Secs. 1 through 4 and 8 through 36.

T. 3 N., R. 26 E., Secs. 25, 35, and 36 .

T. 1 N., R. 27 E., Secs. 1 through 36.

T. 2 N., R. 27 E., Secs. 1 through 36.

T. 3 N., R. 27 E., Secs, 13 through 15 and 19 through 36 .

T. 1 N., R. 28 E., Secs. 1 through 36.

T. 2 N., R. 28 E., Secs. 3 through 10 and 14 through 36.

T. 3 N., R. 28 E., Secs. 19 and 29 through 33.

T. 1 N., R. 29 E., Secs. 6, 7, 17 through 20, and 29 through 33 .

T. 2 N., R. 29 E., Sec. 31 .

T. I S., R. 26 E., Secs. 1 through 5, 8 through 16, 21 through 28 , and 33 through 36

T. 2 S., R. 26 E., Secs. 1 through 4, 9 through 16, 22 through 27, and 34 through 36

T. 3 S., R. 26 E., Secs. 1 through 3, 10 through 15, 23 through 26, 35, and 36.

T. 4 S., R. 26 E., Secs. 1 and 12.

T. I S., R. 27 E., Secs. 1 through 36.

T. 2 S., R. 27 E., Secs. 1 through 36.

T. 3 S., R. 27 E., Secs. 1 through 36.

T. 4 S., R. 27 E., Secs. 1 through 18.

T. 1 S., R. 28 E., Secs. 1 through 36.

T. 2 S., R. 28 E., Secs. 1 through 36.

T. 3 S., R. 28 E., Secs. 1 through 36.

T. 4 S., R. 28 E., Secs. 1 through 18, 23, and 24.

T. 1 S., R. 29 E., Secs. 4 through 9, 15 through 22, and 26 through 35.

T. 2 S., R. 29 E., Secs. 1 through 36.

T. 3 S., R. 29 E., Secs. 1 through 36.

T. 4 S., R. 29 E., Secs. I through 29,33 , and 34 .

T. 2 S., R. 30 E., Secs. 18, 19 , and 30 through 32 .

T. 3 S., R. 30 E., Secs. 5 through 9, 16 through 21 , and 28 through 33 .

T. 4 S., R. 30 E., Secs. 5 through 8 and 17 through 19.

The area described aggregates 460,256 acres, more or less.

Source: Federal Register, Vol. 36, No. 65, p. 6442, Saturday, April 3, 1971. 
APPENDIX II

ADVISORY COMMITTEE

Members

James Griswold

Andrea Lawrence

Warren Longwill

Gerald Maloney*

Charles McDonald

Leroy Mohorich

Phil Pister

Evan Romney

Robert Sandy

Carl Strojan

Warren Smith

James Wickser

Syd Willard
Affiliation

Southern California Edison Company (Rosemead)

Citizen (Mammoth Lakes)

Bureau of Land Management (Bakersfield)

Great Basin Unified Air Pollution Control District (Bishop)

U.S. Forest Service (Bishop/Pasadena)

U.S. Geological Survey (Menlo Park)

California Department of Fish and Game (Bishop)

University of California (Los Angeles)

Mono County Planning Department (Bridgeport)

University of California (Los Angeles)

Union 0 il Company (Santa Rosa)

Los Angeles Department of Water and Power (Bishop)

California Energy Commission (Sacramento)

*resigned from office before completion of our study. 


\title{
APPENDIX III
}

\author{
AGENDA \\ Geothermal Workshop, Mono-Long Valley KGRA \\ Warming Hut 2 on Mammoth Mount ain \\ Canyon Blvd. at Ski Areas $7 \propto 8$ \\ Mammoth Lakes, California \\ August $10-11,1978$
}

Thursday, August 10, 1978
$8: 15-9: 00 \quad$ Registration
9:00 - 9:05 Opening remarks
Evan Romney, University of California, Los Angeles
9:05 - 9:15 Objectives of the Geothermal Overview Program
Paul Phelps; Lawrence Livermore Laboratory
$9: 15-9: 30 \quad \begin{gathered}\text { General Overview of Mono-Long Valley KGRA } \\ \text { Carl L. Strojan, University of Cal ifornia, Lo }\end{gathered}$
$9: 30 \quad-9: 55 \quad$ U.S. Geological Survey Research in Long Valley
Franklin H. Olmsted, U.S. Geological Survey
9:55 - 10:20 Geothermal Energy Technology James W. Griswold, Southern California Edison Co.
$10: 20-10: 40$ Break
10:40 - 11:00 Geothermal Development Scenarios
Charles D. Fredrickson, JPL - California Institute of Technology
11:00 - 11:25 Geothermal Space Heating at Mammoth Lakes
Richard G. Campbel1, The Ben Holt Co.
$11: 25$ - 11:50 U.S. Forest Service Land Management Plans
011 ie Sapousek, U.S. Forest Service
$11: 50-1: 00 \quad$ Lunch
1:00 - 1:20 Chemistry of Long Vall ey Geothermal Waters John Evans, Battelle-Pacific Northwest Laboratories
$1: 20$ - 1:45 Archaeology of the Mono-Long Valley Area
Robert $L$. Bettinger, University of California, Riverside and New York University 


\section{AGENDA (Cont inued)}

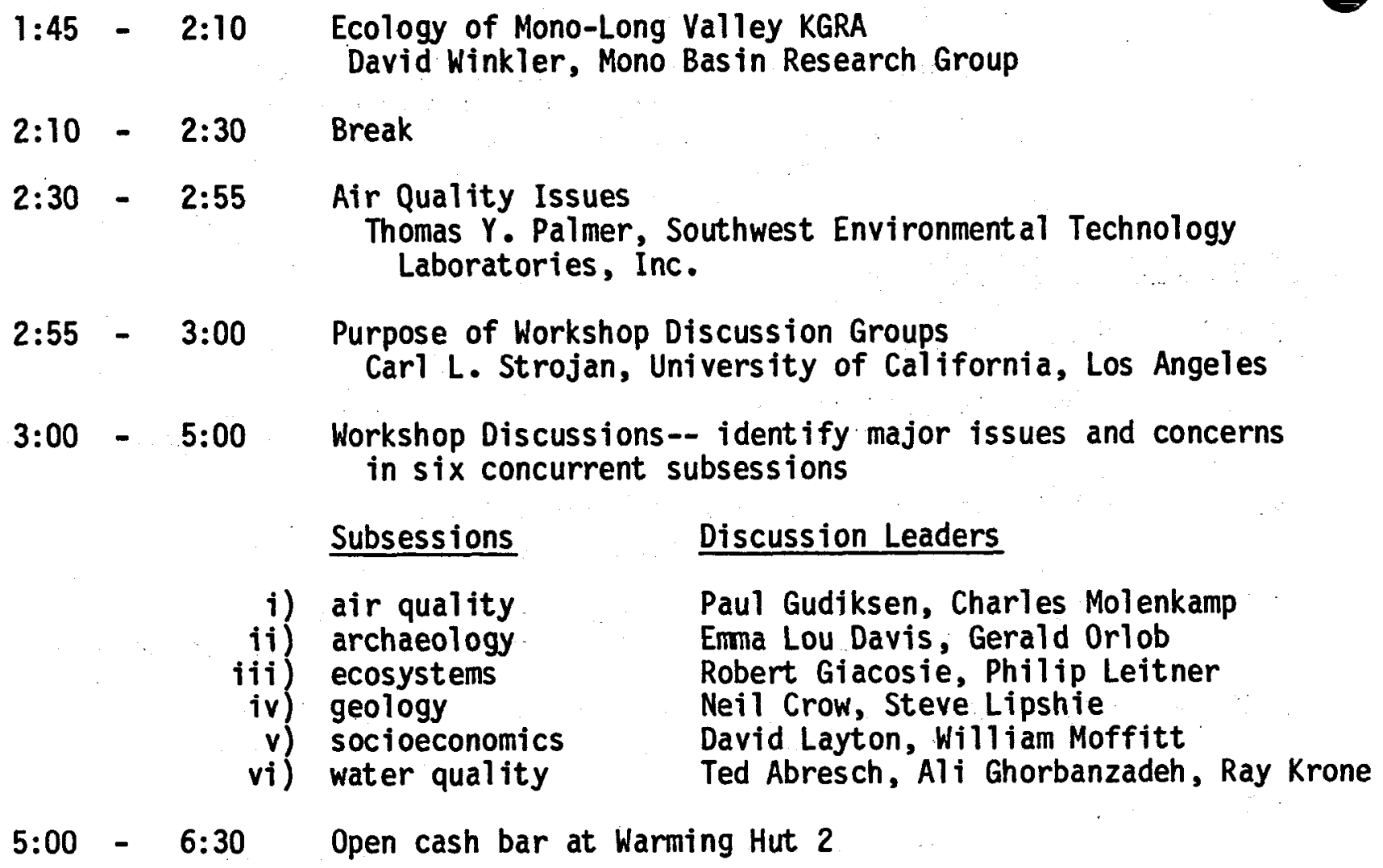

Subsessions

i) air quality

ii) archaeology

iii) ecosystems

iv) geology

v) socioeconomics

vi) water quality

\section{Discussion Leaders}

Paul Gudiksen, Charles Molenkamp

Ema Lou Davis; Gerald Orlob

Robert Giacosie, Philip Leitner

Neil Crow, Steve Lipshie

David Layton, William Moffitt

Ted Abresch, Ali Ghorbanzadeh, Ray Krone

5:00 - 6:30 Open cash bar at Warming Hut 2

Friday, August 11, 1978

9:00 - 9:30 Review of Previous Day's Work by Discussion Group Leaders

9:30 - 12:00 Continue Discussion Groups

(a) assess existing data base

(b) identify data gaps

(c) prepare discussion group reports

$12: 00-1: 15 \quad$ Lunch

1:15 - 2:30 Presentation of Discussion Group Reports by Group Leaders 


\section{PARTICIPANTS}

Geothermal Energy Workshop

Mammoth Lakes, California

August 10-11, 1978

Ted Abresch

Dept. of Physical Medicine \& Rehabilitation

TB 191

University of California

Davis, California 95616

(916) $752-3447$

John C. Al denbrook

P.0. Box 67

Mammoth Lakes, California 93546

Robert E. Alexander

P.0. Box 241

Mammoth Lakes, California 93546

(714) $934-2650$

Richard Austin, District Ranger

Mammoth Lakes Ranger District

U.S. Forest Service

Mammoth Lakes, California 93546

Roy Bailey

U.S. Geological Survey

Reston, Virginia 22092

Tom Balint

U.S. Forest Service

P.O. Box 326

June Lake, California 93529

M. C. "Tilly" Barling

Code 26309

Naval Weapons Center

China Lake, California 93555

(714) $939-2349$

Henry Bass

State Office of Historic Preservation

P.0. Box 2390

Sacramento, California 95811

(916) 445-8006

Robert L. Bettinger

Department of Anthropology

New York Uni versity

25 Waverly Place

New York, New York 10003

(212) $598-3257$
Robert Butler

Cherron Resources Company

P.0. Box 3722

San Francisco, California 94119

(415) $894-2594$

Richard G. Campbell

The Ben Holt Company 201 South Lake Avenue Pasadena, California 91101 (213) $684-2541$

Dean Cornett, L-453

Lawrence Livermore Laboratory

P.0. Box 808

Livermore, California 94550

Neil Crow

Lawrence Livermore Laboratory

P.0. Box 808

Livermore, California 94550

(415) $422-6458$

Frank Daniels

Bureau of Land Management 873 North Main Street Bishop, California 93514

Emma Lou Davis

Great Basin Foundation

1236 Concord St.

San Diego, California 92106

(714) $224-8340$

Paul and Mary DeDecker P.0. Box 506

Independence, Cal ifornia 93526

(714) $878-2389$

Bob and Clara Dinsmore Inyo Planning Board

306 East Line Street Bishop, California 93514

Rollin and Grace Enfield Rt. 2, Box $150 \mathrm{~A}$

Bishop, California 93514 
John Evans

Battelle-Pacific Northwest Laboratories

P.0. Box 999

Richland, Washingt on 99352

(509) 942-5664

Mary Farrell

U.S. Forest Service

P.0. Box 303

Lee Vining, Cal ifornia 93541

Nichol as Faust

U.S. Forest Service

Box 315

June Lake, California 93529

Richard Foss

Magma Power Company

631 Witmer Street

Los Angeles, California 90017

(213) 483-2285

Charles 0 . Fredrickson

Jet Propulsion Laboratory

California Institute of Technology

4800 Oak Grove Drive

Pasadena, California 91103

(213) $577-9260$

David Gaines

Mono Basin Research Group

Lee Vining, California 93541

Ali Ghorbanzadeh

IB Veihmeyer Hall

University of California

Davis, California 95616

(916) 752-6874

Robert Giacosie

Department of Biological Sciences

California State University,

Dominguez Hills

Carson, California 90747

(213) 515-3365

Pete Gray

3036 Clairmont Avenue

Fullerton; California 93625

James Griswold

Southern California Edison Company

P.0. Box 800

2244 Walnut Grove Avenue

Rosemead, California 91770

(213) $572-2775$
Paul Gudiksen, L-262

Lawrence Livermore Laboratory

P.0. Box 808

Livermore, California 94550

(415) $422-1813$

Emma A. Hellstrom

8185 West Bell Drive

Atwater, California 95301

Thomas Jenkins

P.0. Box 336

June Lake, California 93529

James Johnston

U.S. Forest Service

Lassen National Forest

707 Nevada Street

Susanville, California 96103

John S. Kirby-Smith

University of California

900 Veteran Avenue

Los Angeles, California 90024

(213) 825-7702

Dale Kite

Inyo National Forest

873 North Main

Bishop, California 93514

G. Kolbe

Box 178

Santa Ana, California 92702

Linda Kolbe

24001 Estilo

Mission Viejo, California 92675

John Koranda, L-453

Lawrence Livermore Laboratory

P.0. Box 5507

Livermore, California 94550

(415) $422-3840$

Diori Kreske

Code 26305

NWC

China Lake, California 93555

(714) 939-3639

Kim Krompass

4177 Sunset Lane

Hollywood Beach California 93030 
ay Krone

oll lege of Engineering

2132 Banier. Hall

University of California

Davis, California 95616

(916) $752-1435$

Clyde Kuhn

P.0. Box 69

Davis, California 95616

Andrea Lawrence

P.0. Box 43

Mammoth Lakes, California 93546

(714) 934-2877

David Layton

Lawrence Livermore Laboratory

P.0. Box 808

Livermore, California 94550

(415) $422-3880$

Philip Leitner

Biology Department

Saint Mary's College

Moraga, California 94550

(475) $422-3880$

Steve Lipshie

Dept. of Earth \& Space Sciences

University of California

Los Angeles, California 90024

(213) $825-8147$

Liz McAuliffe

4177 Sunset Lane

Oxnard, California 93030

Charles K. McDonald

U.S. Forest Service

150 S. Los Robles Ave.

Pasadena, California 91101

(213) 577-0050

Robert H. Mariner

U.S. Geological Survey

345 Middlefield Road

Menlo Park, California 94025

(415) 323-8111, Ext. 2548

Roger C. Martin

lifornia Division of Mines and Geology

707 South Broadway

Los Angeles, California 90012
Diane and John Mawby

Deep Springs College

via Dyer, Nevada 89010

John M. Melack

Department of Biological Sciences

University of California

Santa Barbara, California 93106

(805) 961-3879

Paul M. Merifield

Environmental Science \&

Engineering Program

University of California

Los Angeles, California 90024

(213) 825-7675

Doreen Meyer

Department of Electrical Engineering

University of California

Davis, California 95616

Lowell Miller

U.S. Department of Energy

1333 Broadway

Oakland, California 94612

(415) 273-7963

William J. Moffitt

University of California

900 Veteran Avenue

Los Angeles, California 90024

(213) 825-9433

Leroy Mohorich, MS-92

U.S. Geological Survey

345 Middlefield Road

Menlo Park, California 94025

(415) 323-8111, Ext. 2851

Charles Molenkamp, $L-262$

Lawrence Livermore Laboratory

P.0. Box 808

Livermore, Califonria 94550

(415) $422-1827$

Neil A. Moyer

California Air Resources Board

P.0. Box 2815

Sacramento, Cal ifornia 92521

John O'Connor

1009 Via Sorella

Walnut, California 91786 
Dennis 01mstead

Division of $0 i 1$ and Gas

1416 Ninth Street, Room 1316

Sacramento, California 95815

(916) 445-9686

Frank lin H. 01msted, MS-67

U.S. Geological Survey

345 Middlefield Road

Menlo Park, California 94025

(415) $323-8111$, Ext. 2631

Gerald T. Orlob

Resource Management Associates

3706 Mt. Diablo Blvd., Suite 200

Lafayette, California 94549

(415) 284-9071

Thomas $Y$. Palmer

Southwest Environmental Technology Laboratories, Inc.

823 South Ridge Drive

Fallbrook, California 92028

(714) 728-4567

Cora Perry

17175 Via Magdalena

San Lorenzo, California 94580

Kendall R. Peterson, L-262

Lawrence Livermore Laboratory

P.0. Box 803

Livermore, California 94550

(415) 422-1829

Paul Phelps, L-453

Lawrence Livermore Laboratory

P.0. Box 808

Livermore, California 94550

(415) $422-3380$

Kenneth D. Pimentel

Lawrence Livermore Laboratory

P.0. Box 808

Livermore, California 94550

(415) $422-3880$

E. Philip Pister

California Department of

Fish and Game

407 West Line Street

Bishop, California 93514

(714) 873-4095
Ronald E. Powell

California Department of Fish and Game

P.0. Box B-D

Blythe, California 92225

(714) 922-5613

Charles Priddy

Cal ifornia State Lands Comnission

100 Oceangate, Suite 300

Long Beach, California 90802

(213) $590-5243$

Craig Racine

Science Applications, Inc.

1200 Prospect Street

La Jolla, Cal ifornia 92037

(714) $459-0211$

Walter Randall

Geothermal Resources International, Inc

4676 Admiralty Way, Suite 503

Marina del Rey, California 90291

(213) $821-8802$

William Rhoads

EG \& G Corporation

P.0. Box 98

Goleta, California 93017

Evan M. Romney

University of California

900 Veteran Avenue

Los Angeles, California 90024

(213) 825-8776

Marty Rosen

Archaelogical Survey

University of California

Los Angeles, California 90024

(213) 825-7411

John Sakaguchi

VTN

2301 Campus Drive

P.0. Box C-19529

Irvine, California 92713

(714) $833-2450$

011 ie Sapousek

U.S. Forest Service

Inyo National Forest

873 North Main Street

Bishop, California 93514

(714) 873-5841 
William Self

Box 422

June Lake, California 93529

Douglas Sherburne

County of Inyo/IMAGE

County Courthouse

Independence, California 93526

Marjorie Sill

720 Brookfield Drive

Reno, Nevada 89503

(702) 322-2867

Greg Simay

City of Burbank

P.0. Box 631

Burbank, California 91503

(213) $847-9636$

Mark T. Smith, District Ranger

Mono Lake District

U.S. Forest Service

P.0. Box 10

Lee Vining, California 93541

(714) 647-6525

Warren A. Smith

Union Geothermal Division

Union 0 il Company

P.0. Box 6854

Santa Rosa, California 95406

(707) 542-9543

Carl L. Strojan

University of California

900 Veteran Avenue

Los Angeles, Cal ifornia 90024

(213) 825-1403

Glenn Suter

B1dg. 1505

Oak Ridge National Laboratory

P.0. Box X

Oak Ridge, Tennessee 37830

(615) 483-8611, Ext. 30260

Danilea Sydlik

10622 Rancho Santiago

Orange, California 92669

Jean and Lewis Tadlock

$135 \mathrm{~S}$. Myrt le Avenue

Tustin, California 92680
Joy Thornbury

University of California

900 Veteran Avenue

Los Angeles, California 90024

(213) 825-9431

Carolyn Trindle

VTN

2301 Campus Drive

P.0. Box C-19529

Irvine, California 92713

(714) $833-2450$

Marc Trumel

Jet Propulsion Laboratory

California Institute of Technology

4800 Dak Grove Drive

Pasadena, California 91103

(213) $577-9310$

Frederick B. Turner

University of California

900 Veteran Avenue

Los Angeles, California 90024

(213) 825-8773

Larry Wade

Inyo National Forest

873 North Main Street

Bishop, California 93514

(714) 873-5841

James F. Wickser

Los Angeles Department of Water \& Power

873 North Main Street

Bishop, Cal ifornia 93514

(714) 873-6968

Phil Wilkie

Archaeological Research Unit

University of California

Riverside, California 92521

Syd Willard, MS-42

California State Energy Commission

1111 Howe Avenue

Sacramento, California 95825

David Winkler

University of California

Museum of Vertebrate Zoology

2593 Life Sciences Building

Berkeley, California 94720 
Randy Witters

U.S. Forest Service

Mammoth Lakes Ranger District

Mammoth Lakes, California 93546

(714) $934-2505$

Darrell Wong

California Department of Fish and Game 407 West Line Street

Bishop, California 93514 